ACTA

UNIVERSITATIS

CAROLINAE

IURIDICA 1/2019

Vol. LXV 



\section{IURIDICA $1 / 2019$ Vol. LXV}


Vědecký redaktor: JUDr. Jakub Tomšej, Ph.D.

Všechny články tohoto čísla byly recenzovány.

http://www.karolinum.cz/journals/iuridica

(C) Univerzita Karlova, 2019

ISSN 0323-0619 (Print)

ISSN 2336-6478 (Online) 


\section{OBSAH}

Jan Pichrt, Jakub Tomšej: Předmluva: Aktuální otázky závislé práce $\ldots \ldots \ldots \ldots \ldots \ldots$. 7

David Falada, Kamila Stloukalová: Ř́mskoprávní základy úpravy

závislé práce .................................... 9

David Kohout: Právní postavení sportovních trenérů v České republice . . . . . . . . . . . 19

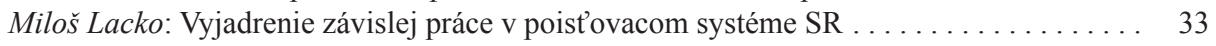

Ján Matejka: Doručování písemností a elektronický právní styk

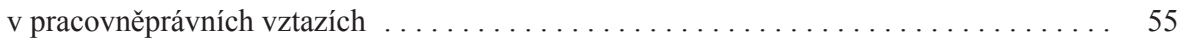

Jakub Morávek: Závislá práce a její právní regulace na počátku 21. století -

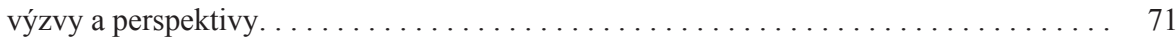

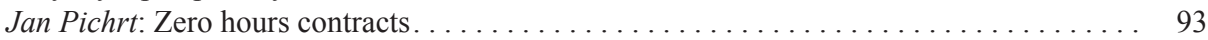

Andrej Poruban: Medzi zamestnancom a samostatne zárobkovo činnou osobou . . . . . . 103

Lucie Matějka Řehořová: Náhrada nemajetkové újmy a další právní vztahy

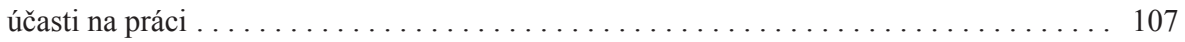

Patrik Stonjek: Vybraná specifika pracovněprávních sporů

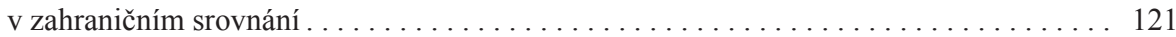

Martin Štefko: Názor rejstř́kových soudů: odborová organizace spolkem, či raději ne?

Jakub Tomšej: Výpověd' pro nadbytečnost a kritéria výběru:

komparativní srovnání. 



\section{PŘEDMLUVA: AKTUÁLNÍ OTÁZKY ZÁVISLÉ PRÁCE}

Institut závislé práce prochází neustálým vývojem. Vývoj lidské společnosti a poznání v 21. století v mnohých oblastech vede $\mathrm{v}$ současnosti $\mathrm{k}$ dynamičtějším změnám pracovních podmínek, než tomu bylo v nedávné minulosti; je výzvou pro současnou právní teorii zamýšlet se nad tím, do jaké míry a jakým způsobem je vhodné reflektovat tyto změny i v pracovněprávní legislativě a její interpretaci. Dochází k posilování staronových trendů, jakými jsou globalizace a robotizace práce, i k vymezování trendů nových, za jaké bývají v souvislosti s rozmachem tzv. ekonomiky sdílení označovány nové formy výkonu závislé práce, které často ve svých důsledcích vedou k oslabování dosavadních pracovněprávních jistot zaměstnanců.

Právě proto jsme závislou práci zvolili za centrální téma výzkumu, jemuž se věnujeme v rámci univerzitního centra UNCE/HUM/034 „Závislá práce v 21. století - otázky a výzvy“ na Právnické fakultě Univerzity Karlovy. Jedním z hlavních cílů centra je pojednat o problematice závislé práce multioborovým způsobem, s důrazem na pracovněprávní pohled, avšak současně s vědomím toho, že př́slušné právní vztahy nelze komplexně zanalyzovat a popsat bez synergií s obchodním právem, správním právem, ale třeba i se sportovním právem a dalšími odvětvími.

Předkládané monotematické vydání časopisu Acta Universitatis Carolinae Iuridica představuje (spolu s dalšími publikačními počiny) určité završení prvního roku fungování a výzkumu zmiňovaného univerzitního centra. Byt' si jednotliví autoři zvolili pro své př́spěvky různá témata, je jim společná snaha analyzovat současné instituty pracovního práva s využitím získaných poznatků ze zahraničí, včetně evropského práva, a hledání nových cest a možností de lege ferenda. V mnoha př́ípadech se přitom jedná i o analýzy institutů nebo otázek zcela nových, v českém právu dosud výslovně neupravených či v českém akademickém prostředí dosud jen okrajově diskutovaných.

Kolektiv autorů univerzitního centra UNCE byl doplněn o tři odborníky mimo Univerzitu Karlovu, jejichž výzkumné aktivity s těmi našimi souzní. 
Přejeme čtenářum, aby v tomto vydání časopisu našli co nejvíce inspirativních myšlenek, a těšíme se, že publikované články přispějí k další akademické diskusi na téma proměn závislé práce i dalších souvisejících institutů.

doi: $10.14712 / 23366478.2019 .1$

Jan Pichrt, Jakub Tomšej

Toto vydání a př́spěvky v něm zveřejněné (pokud není u jednotlivých př́íspěvků uvedeno jinak) vznikly v rámci projektu UNCE/HUM/034 „Závislá práce v 21. století: otázky a výzvy“ na Právnické fakultě Univerzity Karlovy (www.zavisla-prace.cz). 


\title{
ŘÍMSKOPRÁVNÍ ZÁKLADY ÚPRAVY ZÁVISLÉ PRÁCE
}

\author{
DAVID FALADA, KAMILA STLOUKALOVÁ*
}

\begin{abstract}
Roman-Law Basics of the Dependent Labour
The article endeavours to introduce certain basic aspects of the position of a dependent labourer in the Roman world. Such introduction involves information on the systemisation of the relevant employment contract (the locatio conductio operarum) within the framework of Roman obligations, as well as its distinction from similar contracts having identical roots, i.e., the lease of an object (the locatio conductio rei) and the contract for work (the locatio conductio operis). In addition, a brief description of the values respected by the Romans must be included as well, as the behaviour of the Roman society establishes a contextual environment for the limited utilisation of the employment contract.
\end{abstract}

Keywords: Roman law; employment law; dependent labour; locatio conductio; employment contract

Klíčová slova: římské právo; pracovní právo; závislá práce; locatio conductio; pracovní smlouva

DOI: $10.14712 / 23366478.2019 .2$

\section{ÚVOD}

Závislá práce je v § 2 zákona č. 262/2006 Sb., zákoník práce, ve znění pozdějších předpisů (dále jen „zákoník práce“), charakterizována následovně:

(1) Závislou prací je práce, která je vykonávána ve vztahu nadřízenosti zaměstnavatele a podřízenosti zaměstnance, jménem zaměstnavatele, podle pokynů zaměstnavatele a zaměstnanec ji pro zaměstnavatele vykonává osobně.

(2) Závislá práce musí být vykonávána za mzdu, plat nebo odměnu za práci, na náklady a odpovědnost zaměstnavatele, $v$ pracovní době na pracovišti zaměstnavatele, popř́padě na jiném dohodnutém místě.

$\mathrm{K}$ výše uvedeným znakům se přidává v § 3 zákoníku práce ještě požadavek jejího výkonu výlučně v základním pracovněprávním vztahu, kterým je pracovní poměr nebo právní vztahy založené dohodami o pracích konaných mimo pracovní poměr (dohoda

* David Falada je odborným asistentem a Kamila Stloukalová doktorandkou na katedře právních dějin Právnické fakulty Univerzity Karlovy. 
o provedení práce, dohoda o pracovní činnosti), za předpokladu, že neexistuje úprava speciální, např́íklad zákon č. 234/2014 Sb., o státní službě.

Lze rovnou konstatovat, že takovéto vymezení v římském právu nenalezneme. I přesto však nelze říci, že by pro právní úpravu závislé práce bylo rrímské právo zcela nezajímavou materií. Samozřejmě i ve starověkém Římě existovala potřeba pracovní síly, byt' byla obstarávána do velké míry jinak než dnes.

Značná část prací spočívala na bedrech osob v různých stadiích závislosti na zadavateli (zaměstnavateli), a to nikoli závislosti v dnešním pracovněprávním smyslu, ale ve smyslu statusovém. Můžeme tak rozlišit, zda práci vykonávají:

a) otroci, tedy z hlediska přirozeného práva sice osoby, z pohledu římského práva civilního objekty práv, jejichž podřízenost je na naší pomyslné škále nejsilnější. ${ }^{1}$ Otrocká práce byla nejvýznamnější pracovní silou a základem římské výroby jak v oblasti agrární, tak řemeslné; 2

b) osoby sice svobodné, ale zároveň z určitého důvodu nucené vykonávat práci pro druhou osobu. Sem spadá různorodá směsice lidí, jejichž právní postavení se liší: zařadíme sem především rodinné příslušníky, spadající pod moc otce rodiny, ${ }^{3}$ kteří jsou společně s otroky nejčastější pracovní silou používanou v Římě. ${ }^{4}$ Dále můžeme zmínit propuštěnce, tedy ty, kteří dříve bývali otroky, ale jejich původní pán je ze své moci osvobodil - propustil na svobodu. Ti svému patronovi (bývalému pánovi) dávali slib (promissio iurata operarum) či se zavazovali stipulací, že budou vykonávat určité ve slibu specifikované práce (operae). ${ }^{5}$ Tak vznikla právní povinnost a propuštěnec mohl být žalován při jejím neplnění pomocí actio operarum nebo actio ex stipulatu. ${ }^{6} \mathrm{~V}$ této skupině se nám také vyskytnou např́klad osoby v mancipiu ${ }^{7}$ z důvodu noxálního ručení, ${ }^{8}$ insolventní dlužník přiřčený věřiteli, aby si u něj odpracoval svůj dluh, ${ }^{9}$ atd.

Avšak teprve třetí skupina nás bude zajímat v tomto prŕíspěvku nejvíce:

1 Otroci byli tzv. res mancipi, mancipační věci, jejichž převod se odehrával velmi formálním jednáním, mimo jiné proto, aby se mu dostalo náležité publicity, nebot' šlo o nejvýznamnější části majetku římských občanů.

2 ÜROGDI, G. Tak žil starý Řim. Praha: Orbis, 1968, s. 147. K vývoji otrockých prací a jejich charakteru a vzestupu jejich důležitosti v historii Ř́ma viz např. ALFÖLDY, G. Storia sociale dell'antica Roma. Bologna: Il Mulino, 1987, s. 25, 61 an., 84 an., 190 an. et passim.

3 Šlo o manželku podřízenou moci manželské (manus) a potomky podřizené moci otcovské (patria postestas).

4 Viz např. ALFÖLDY, c. d., s. 25.

5 Operae liberti mohly spočívat zejména v osobních službách (operae officiales) nebo odborných pracích v oblasti řemeslné či umělecké (operae fabriles). BARTOŠEK, M. Encyklopedie řimského práva. Praha: Academia, 1994, heslo: opus.

6 Patron však nesměl požadovat služby či práce v nadměrné míře. Tamtéž.

7 Mancipium je moc otce rodiny nad osobami, které jsou mu podř́zeny, ale nejsou jeho potomky, nad nimiž vykonává moc otcovskou (patria potestas), ani jeho manželkou, nad níž vykonává moc manželskou (ma$n u s$ ), ani otroky, nad nimiž vládne mocí nazývanou dominica potestas.

8 Jejich postavení lze popsat jako servorum loco, tj. na místě otroků. V př́ípadě, že osoba podřizená otcovské moci spáchala delikt, měl otec rodiny možnost bud’ škodu kompenzovat př́islušnou peněžní částkou, nebo převést poškozenému pod moc tuto podřízenou osobu, aby si u něj svou prací způsobenou škodu odpracovala (př́ípadně kombinovat obě varianty).

9 Původně mohl věřitel přiřčeného dlužníka (addictus) zabít či prodat do otroctví, pokud jej nikdo ve stanovené lhůtě nevykoupil. REBRO, K. - BLAHO, P. Rímske právo. Bratislava - Trnava: Wolters Kluwer (Iura Edition), 2003, s. 127. 
c) osoby svobodné, dobrovolně se zavazující k práci, a to pomocí smlouvy latinsky zvané locatio conductio.

\section{LOCATIO CONDUCTIO - CHARAKTERISTIKA A DRUHY}

Locatio conductio (pronájem-nájem) je smlouva, jíž se jedna osoba zavazuje k určité úplatě za užívání či požívání věci, za práci či za dílo poskytnuté jí druhou osobou. Římané ji považovali za jednotnou smlouvu, ${ }^{10}$ přestože ve své podstatě zahrnuje tři různé smluvní typy - smlouvu nájemní (locatio conductio rei), smlouvu o dílo (locatio conductio operis) a smlouvu pracovní (locatio conductio operarum). Z praktického hlediska však k jejich odlišení docházelo, nebot’ každá smlouva měla své zvláštní společenské a hospodářské znaky, jichž si římští právníci byli vědomi. K teoretickému dělení do výše uvedených tří forem však došlo až v období německé pandektistiky (usus modernus pandectarum), samozřjejmě na základě kazuisticky zpracovaných případů římských právníků. ${ }^{11}$ Moderní důraz na systemizaci a dogmatickou kategorizaci by však neměl zastínit skutečnost, že takový přístup je ve své podstatě ahistorický a římskému myšlení vzdálený, byt' nám v současné době samozřejmě umožňuje lepší orientaci v římskoprávní materii.

Název locatio conductio popisuje z pohledu obou smluvních stran, co se děje s předmětem smlouvy. Locare lze přeložit jako umístit, ${ }^{12}$ dát, klást na určité místo, conducere jako svádět dohromady, sbírat. ${ }^{13} \mathrm{~V}$ tom lze podle Reinharda Zimmermanna ${ }^{14}$ vysledovat jádro toho, co spojuje tři zdánlivě odlišné smluvní typy pod hlavičku jedné smlouvy: v př́ípadě nájemní smlouvy pronajímatel (locator) umist'uje věc do nájemcovy dispozice, nájemce (conductor) ji přebírá ke svému užitku; u smlouvy o dílo objednatel (locator) zadává určitou práci, zatímco zhotovitel (conductor) ji přebírá, a to včetně věcí, kterých je třeba k vykonání díla; a nakonec u pracovní smlouvy je zaměstnanec (locator) tím, kdo svou pracovní sílu dává k dispozici zaměstnavateli (conductor). Jak upozorn̆uje R. Zimmermann, jednotnost této smlouvy je založena na hledisku terminologickém a procesním, z praktického hlediska však s trichotomií tohoto kontraktu pracovali, jak již bylo uvedeno, i samotní římští právníci.

Co se týče základních znaků této římskoprávní smlouvy, řadíme ji mezi kontrakty konsenzuální, ${ }^{15}$ neformální, dvoustranné rovné (synallagmata). Ke vzniku závazku tedy postačovala dohoda o podstatných náležitostech této smlouvy - předmětu smlouvy

10 BARTOŠEK, Encyklopedie řimského práva, heslo: locus. V římskoprávních pramenech výslovnou trichotomii locatio conductio rei-operis-operarum nenajdeme.

11 DAJCZAK, W. - GIARO, T. - LONGCHAMPS DE BÉRIER, F. Právo rímské. Základy soukromého práva. České vydání P. Dostalík. Olomouc: Iuridicum Olomoucense, 2013, s. 339-340. K tomu viz např. literaturu v pozn. č. 1 na s. 338 v ZIMMERMANN, R. The Law of Obligations. Roman Foundations of the Civilian Tradition. Oxford: Claredon Press, 1996.

12 Viz Var. De l. l. V, II, 14-15. VARRO, MARCUS TERENTIUS. De lingua Latina V-VII. Přel. Lucie Pultrová. Praha: Filozofická fakulta Univerzity Karlovy, 2015, s. 45-47.

13 PRAŽÁK, J. M. - NOVOTNÝ, F. - SEDLÁČEK, J. Latinsko - český slovnik k potřebě gymnasii a reálných gymnasií, 10. vyd. Praha: Československá grafická unie, 1937, heslo conducere.

14 Toto odůvodnění uvádí ZIMMERMANN, c. d., s. 339.

15 I. 3, 22pr. 
a úplatě, tj. závazek vznikal nudo consensu, na rozdíl od kontraktů reálných, k jejichž vzniku bylo vedle konsensu třeba ještě předání dotčené věci. ${ }^{16} \mathrm{~K}$ uzavření locatio conductio se nepožadovalo splnění žádné konkrétní formy v protikladu ke smlouvám formálním - verbálním či literárním -, u nichž byl vznik podmíněn naplněním stanovené formy, tj. vyřčením stanovených slov či př́islušným zápisem. Závazky dvoustranné rovné spočívaly v tom, že práva a povinnosti náležely oběma stranám, což znamenalo, že každé smluvní straně byla dána žaloba na vymožení splnění určité smluvní povinnosti druhé strany. Žaloby nazývané actio locati a actio conducti už svým názvem vycházejí z toho, která ze smluvních stran je mohla použít. Jedná se o žaloby v dobré víře ( $a c$ tiones bonae fidei) vyznačující se tím, že soudce bral v úvahu různé vedlejší úmluvy a okolnosti souzeného př́padu, což jej vedlo k rozhodnutí v zájmu spravedlivého usporrádání zájmů stran. ${ }^{17}$ Soudce tak obdržel dostatečnou diskreční pravomoc, aby mohlo dojít k rozlišení specifik jednotlivých typů locatio conductio.

Počáteční vývoj locatio conductio není zcela zřejmý, nebot' nemáme dostatek pramenů, abychom jej s jistotou zrekonstruovali. Nicméně v průběhu republiky praetor umožňuje vymoci závazek z této smlouvy, která např. podle Leopolda Heyrovského vznikla původně v oblasti státního majetkového práva. ${ }^{18}$ Právní konstrukcí se velmi blíží rímské kupní smlouvě (emptio venditio), na což upozorňují i ř́mskoprávní prameny. ${ }^{19}$ Důvodem jejich blízkosti jsou především společné charakteristické rysy - existence úplaty: kupní ceny a nájemného; skutečnosti, že obě strany jsou, hovoříme-li ve zcela obecné rovině, povinny něco předat a oprávněny něco obdržet. Právě ona úplatnost pak liší locatio conductio od výpůjčky (commodatum) či př́íkazu (mandatum), které jsou typicky bezplatné.

Chceme-li rozlišit tři formy locatio conductio, pak bodem, na který se zaměříme, je předmět této smlouvy. $\mathrm{V}$ př́padě locatio conductio rei, tedy nájmu v užším slova smyslu, tzv. věcném, je předmětem věc (res), at’ už movitá či nemovitá, nebo právo (napřr. nájem státních př́íjmů, zejména tedy právo vybírat státní daně - locatio vectigalium). U pracovní (v literatuře někdy služební nebo také námezdní) ${ }^{20}$ smlouvy (locatio conductio operarum) se jedná o operae, určité práce bez nutnosti dosažení konkrétního výsledku, který by se nazýval opus a jehož vytvoření je cílem třetího smluvního typu locatio conductio operis. ${ }^{21}$ Odlišnost posledních dvou uvedených typů smlouvy spočívá v tom, že první z nich cílí na práci jako takovou, druhý na její výsledek.

16 Podle Silvia Perozziho však v klasickém právu byla smlouva o nájmu (locatio conductio rei) prefektní až $\mathrm{v}$ okamžiku předání věci. PEROZZI, S. Istituzioni di diritto romano. Vol. II. Firenze: G. Barbèra, editore, 1908, s. 231.

17 BARTOŠEK, Encyklopedie řimského práva, heslo: ius. SKŘEJPEK, M. Římské soukromé právo. Systém a instituce. Plzeň: Aleš Čeněk, 2011, s. 256.

18 Př́íklady uvádí HEYROVSKÝ, L. Dějiny a systém soukromého práva řimského. Díl II., 5 vyd. Praha: J. Otto, 1921, s. 150. Též JOLOWICZ, H. F. - NICHOLAS, B. Historical Introduction to the Study of Roman Law, 3rd edition. Cambridge - New York - London - Melbourne: Cambridge University Press, 1972, s. 295. K historickým aspektům vývoje locatio conductio srov. též ZIMMERMANN, c. d., s. 350-351.

19 Např. D. 19, 2, 2pr., I. 3, 24pr., Gai 3, 142.145.

20 HEYROVSKÝ, c. d., s. 156 nebo KINCL, J. - URFUS, V. - SKŘEJPEK, M. Římské právo. Praha: C. H. Beck, 1995 (2. vyd. / 1. vyd. v C. H. Beck v tomto kolektivu autorů), s. 254.

21 Právě mezi locatio conductio operis a emptio venditio mnohdy spočívala pouze tenká hranice, kterou tvořilo předání materiálu ke zpracování: pokud je dílo z materiálu patř́ícího osobě, která jej vytvořila, jde o emptio venditio, a to i kdyby v době objednání toto dílo neexistovalo a prodávající jej na základě 
Pro úplnost je ale nutné dodat, že - jak již bylo výše naznačeno - je identifikace konkrétního smluvního typu v pramenných materiálech někdy mimořádně obtížná a může vyvolávat i kontroverze. Př́kladem budiž fragment z Paulova komentáře k ediktu, ${ }^{22}$ který v českém překladu zní:

„Ani tehdy, kdybys cestoval lodí bez úplaty, anebo kdyby ses bez úplaty ubytoval v hostinci a kdybys protiprávně utrpěl škodu, nebudou ti odepřeny žaloby založené na popsání skutkového stavu. Jestliže uživáš mého otroka na lodi nebo v hostinci a kdyby mě způsobil škodu nebo kdyby spáchal krádež, pak i když žaloba z krádeže i z protiprávního poškození věci směřuje proti mně, přece jen je takováto žaloba účinná proti tobě, nebot' je založena na popsání skutkového stavu, dokonce i když se týká mého otroka. A totéž se vztahuje na situaci, kdyby se jednalo o našeho společného otroka. Přece však jsem ti zavázán za to, co jsi mě za něho poskytl, a to bud’ žalobou na rozdělení spoluvlastnictví, nebo ze společenské smlouvy, nebo pokud sis najal můj díl, nebo sis najal otroka vcelku, také žalobou z nájmu. "23

V takových situacích totiž velmi záleží i na subtilních nuancích zvoleného překladu, které mohou vést $\mathrm{k}$ různým interpretacím. Pro účely této ilustrace uvádíme, že $\mathrm{k}$ dispozici je i alternativní preklad do češtiny (bez první věty fragmentu), který zní následovně:

„Užíváš-li mého otroka na lodi nebo v hostinci a on mne poškodil nebo okradl, ačkoli proti mně př́slušs žaloba $\mathrm{z}$ krádeže, tak i z protiprávně způsobené škody, přece tato žaloba, ježto má skutkovou povahu, př́śsluší také proti tobě, skrze mého otroka. Totéž je třeba říci, kdyby nám byl (otrok) společný: ty však co bys mi jeho jménem poskytl, budeš mne mít zavázaného žalobou bud' na rozdělení společné věci nebo ze společenské smlouvy, nebo, pronajal-li sis ho zčásti nebo zcela, také žalobou z pronájmu." ${ }^{24}$

Právě ono lavírování mezi původním latinským textem a jeho variantními převody do češtiny, zvláště, týkají-li se volby českého termínu pro onu původně jednotnou smlouvu, zvanou locatio conductio (který v předkládaných českých verzích variuje mezi „pronájmem“a „nájmem“) mohou interpretaci popisované situace znejistit. V tomto konkrétním případu se objevuje celá řada právních vztahů, z nichž pro nás snad nejzajímavější, že vztah mezi svobodným občanem, cestujícím se svým otrokem bezúplatně na lodi, a jejím vlastníkem je díky dohodě mezi vlastníkem otroka a vlastníkem lodi, na jejímž základě je otrok donucen odpracovat svoji i pánovu cestu, takto „prostřednictvím otroka“" možno vnímat jako později definovanou smlouvu locatio conductio operarum, kde vlastník otroka je locator (tedy v dnešní terminologii zaměstnanec), zatímco vlastník

objednávky teprve měl vytvořit. Pokud však př́íslušné věci k výrobě obdržel od objednatele, jde o locatio conductio operis. Obdobnou distinkci však najedeme i dnes v zákoně č. 89/2012 Sb., občanský zákoník, ve znění pozdějších předpisů, $\S 2086$ odst. 1.

22 D. 4, 9, 6pr. - 1. (Paul. 22 ad ed.) Licet gratis navigaveris vel in caupona gratis deverteris, non tamen in factum actiones tibi denegabuntur, si damnum iniuria passus es. Si servo meo in nave vel in caupona utaris et damnum mihi det vel furtum faciat, quamquam et furti actio et damni iniuria mecum sit, haec tamen actio, quia in factum est, etiam servi mei nomine adversus te competit. idem dicetur, et si communis sit: tu tamen quod mihi praestiteris eius nomine, vel communi dividundo vel pro socio actione, aut si partem eius vel totum conduxisti, etiam ex conducto habebis me obligatum.

23 Citováno podle Digesta seu Pandectae, tomus I, liber I-XV, fragmenta selecta. Digesta neboli Pandekty, svazek I, kniha I-XV, vybrané části. Překlad Peter Blaho, Michal Skřejpek, Jarmila Vaňková, Jakub Žytek. Praha: Karolinum, 2015, s. 373.

24 Citováno podle BARTOŠEK, M. Škola právnického myšlení. Praha: Karolinum, 1993, s. 273. 
lodi je conductor (tedy v dnešní terminologii zaměstnavatel). ${ }^{25}$ Práci však v takovémto př́padě podle Milana Bartoška vykonává „zaměstnanec“ prostřednictvím svého otroka. Je ale pochopitelné, že tato interpretace není jediná možná a pro dnešní pojetí závislé práce obtížně pochopitelná.

Jako alternativní výklad se nabízí naopak nájem věci (locatio conductio rei), sjednaný mezi cestujícím-vlastníkem otroka jako pronajímatelem (locator) a vlastníkem lodi jako nájemcem (conductor), kde předmětem nájmu, onou věcí, bude právě tento otrok, přičemž ,nájemné“ bude spočívat v bezúplatné přepravě lodí pro pronajímatele a jeho otroka. Tím bychom se ale dostali mimo rámec této studie.

Věc je ale opět komplikovanější, protože bychom museli ještě otevřít otázku vlastní dohody mezi oním cestujícím a vlastníkem lodi. Zde se opět jako jedna z variant nabízí locatio conductio operarum, kde by však mohl být dohodnut i obrácený poměr mezi stranami, než jak bylo uvedeno výše. Ono totiž cestování zdarma zdaleka není typické. Mnohem obvyklejší je najmutí vlastníka lodi cestujícím za účelem uskutečnění přepravy. V takovém uspořádání by se z cestujícího stal zaměstnavatel (conductor) a z vlastníka lodi zaměstnanec (locator). Otázka práce otroka by pak musela být řešena separátně, pravděpodobně v duchu výše zmíněné locatio conductio rei. Výsledkem by pak mohlo být i vzájemné započtení pohledávek na př́slušná plnění z obou smluv, tj. na mzdu za odvedenou práci a na nájemné za pronajatého otroka.

$Z$ uvedeného krátkého fragmentu (pouhé 4 věty) je zřejmé, že práce s pramennými texty není v žádném př́ípadě jednoduchá, zvláště, hledáme-li v nich konkrétnější informace o kořenech moderní úpravy vztahu mezi zaměstnavatelem a zaměstnancem. ${ }^{26}$

\section{LOCATIO CONDUCTIO OPERARUM}

V dalším textu se zaměříme na jeden z výše uvedených smluvních typů tvořících trichotomii, a to locatio conductio operarum, tedy pracovní smlouvu.

Pramenů $\mathrm{k}$ římské pracovní smlouvě nemáme mnoho, vycházet lze především z ustanovení justiniánských Digest 19, 2 Locati conducti, Codexu 4, 65 De locato et conducto, případně v menším rozsahu $\mathrm{z}$ dalších právních pramenů, ale také z různých epigrafických svědectví, např́íklad z dochovaných zápisů pracovních smluv na bronzových deskách (Corpus Inscriptionum Latinarum, vol. III, s. 948, IX, X a XI). ${ }^{27}$

Dvěma podstatnými náležitostmi tohoto kontraktu jsou ujednání o práci (operae), která má být vykonána, a o odměně, která za ni má být zaplacena (merces). Zaměst-

25 Tak BARTOŠEK, Škola právnického myšlení, s. 274.

${ }^{26}$ I v tomto kontextu musíme ponechat stranou př́padný exkurs do tématiky speciálního vztahu mezi cestujícím a vlastníkem lodi, založeného praetorským paktem receptum nautarum cauponum stabulariorum, kterým se zakládá zvláštní zvýšená odpovědnost vlastníka lodi (př́ípadně provozovatele hostince nebo stájí) za věci svěřené mu cestujícím. Přesto považujeme za vhodné tento rozměr alespoň takto pod čarou připomenout (citovaný fragment koneckonců uvažuje hlavně o škodách na přepravovaném majetku). Tato speciální právní úprava odpovědnosti za svěřené věci svědčí o tom, že v římském světě byla tomuto problému věnována zvláštní pozornost, což opět ukazuje na jeho mimořádnou důležitost pro život tehdejší společnosti. Viz opět BARTOŠEK, Škola právnického myšlení, s. 274.

27 K č. X bliže viz BERGER, A. A Labor Contract of A.D. 164: CIL, III, P. 948, No. X. Classical Philology, 1948, 43(4), 231-242. Dostupné na: <http://www.jstor.org/stable/266923>. 
nanec (locator) poskytuje svou pracovní sílu zaměstnavateli (conductor). Zaměstnanec je povinen vykonávat rádně sjednanou práci po sjednanou dobu. Odpovídá také za způsobenou škodu, lze-li mu přičíst zavinění (a to ve formě úmyslu i nedbalosti). Pro vymožení závazku zaměstnance slouží zaměstnavateli actio conducti. Naproti tomu zaměstnanec může podat actio locati, jíž vymůže zaplacení odměny. Odměna je hrazena zpravidla v penězích po vykonání prŕíslušné práce, resp. za celou dobu, na kterou zaměstnance zaměstnavatel na práci najal. S tím souvisí otázka, kdo nese riziko v případech, kdy práce nemohou být vykonány, jinak řečeno ve kterých př́padech, pokud vůbec, je zaměstnavatel povinen uhradit zaměstnanci odměnu:

D. 19, 2, 38pr. (Paul. lib. sing. reg.): Qui operas suas locavit, totius temporis mercedem accipere debet, si per eum non stetit, quo minus operas praestet. (Kdo pronajme svou práci, má obdržet odměnu za celou dobu, na kterou byl pro práci najat, pokud však tím není vinen, že vykonal méně práce).

Platí tedy, že periculum est conductoris (nebezpečí je na straně zaměstnavatele) a ten je povinen zaplatit ujednanou odměnu i v př́padě, že práci zaměstnanec nemohl vykonat. Výjimka $\mathrm{z}$ tohoto pravidla však nastane $\mathrm{v}$ případě, že příčina nemožnosti konat práci má původ ve sféře vlivu zaměstnance. ${ }^{28}$ Skoro bychom mohli říct, že úvahy o tomto problému jsou zárodkem dnešního institutu překážek v práci na straně zaměstnance a zaměstnavatele.

Smluvní strany si nicméně také podmínky mohou upravit podle vlastního uvážení, ${ }^{29}$ a to včetně oblastí, které dnes jsou kogentně upraveny a nepřipouští se v nich smluvní volnost.

Co se týče charakteru práce, obecně lze říci, že práce pro vlastní potřebu (a to i v zemědělství), případně služby vykonávané bezplatně ve prospěch jiného v duchu přátelství nebo společenské prospěšnosti byly přijatelné pro vyšší třídy. ${ }^{30} \mathrm{U}$ těchto tzv. operae liberales, činností, jimiž se zabývali svobodní výše postavení Rímané, se nepovažovalo za vhodné, aby za ně dotčené osoby obdržely odměnu, resp. nekorespondovalo by to s představou cti těchto osob, které si navíc mohly dovolit bezplatně tyto práce vykonávat. Kdo za úplatu nabízel svoji pracovní sílu, tedy uzavíral pracovní smlouvu, zpravidla pocházel z nižší společenské vrstvy a vykonával tzv. operae illiberales, práce spíše manuálního než intelektuálního charakteru. ${ }^{31}$

Práce musela být vykonávána s řádnou péčí, přičemž se předpokládalo, že zaměstnanec, který se nechal najmout na určitou práci je dostatečně zkušený na to, aby ji zvládl, jinak bude odpovědný za škodu zpo̊sobenou z nedbalosti. ${ }^{32}$

Pracovní smlouva byla uzavírána na dobu určitou a končila tak v dohodnutém termínu, př́padně, pokud doba nebyla stanovena, mohla smlouvu ukončit kdykoli kterákoli ze smluvních stran. Pochopitelně neexistovaly žádné prostředky právní ochrany

28 ZIMMERMANN, c. d., s. 385.

29 Tamtéž. Viz také BERGER, A Labor Contract of A.D. 164: CIL, III, P. 948, No. X, s. 239-240.

30 Jednalo se např́klad o advokáty, architekty, učitele, filozofy, matematiky, řečníky a další.

31 Císařskými reskripty bylo posléze umožněno, aby byly některé intelektuální práce odměňovány platem jako např́iklad služby lékařů, advokátů či učitelů, avšak k jeho vymožení nesloužila actio locati, ale právní ochrany se mohli domáhat pouze v kogničním řízení extra ordinem. Viz HEYROVSKÝ, c. d., s. 156; KINCL - URFUS - SKŘEJPEK, Řimské právo, s. 254.

32 D. 50, 17, 132 (Gai 7 ad ed. prov.): Imperitia culpae adnumeratur. 
zaměstnance ve smyslu moderní povinné výpovědní doby, výpovědních důvodů, či př́ípadného pojištění zaměstnance, at' již při výkonu sjednané činnosti, či pro př́ípad, kdy po propuštění nemohl najít další zaměstnání. $\mathrm{V}$ tomto smyslu bylo právní postavení zaměstnanců podle rrímského práva výrazně slabé, ale v očích tehdejší společnosti vlastně odpovídající jejich společenskému statusu.

Přes toto tvrzení nalézáme však některé prvky určité míry právní - spíše však ekonomické - ochrany zaměstnance. Objevují se nepř́liš systematicky v některých dochovaných smlouvách, případně ve zmínkách o takových smlouvách. Taková zmínka je obsažena např. v D. 19, 2, 19, 9 (Ulp. 32 ad ed.), kde je přiznán nárok bývalého zaměstnance na zaplacení dohodnuté mzdy proti pozůstalosti po jeho zaměstnavateli, přiznaný císařem Septimiem Severem. ${ }^{33}$ Podobně jsou známa ujednání, týkající se poskytování naturálních plnění (jídlo, ošacení) nad rámec samotné mzdy. Pokud však odkazujeme na konkrétní - třeba i zachované - památky, musíme je číst s velkou opatrností. Problém $\mathrm{s}$ nimi spočívá v tom, že musíme počítat se skutečností, že většina zaměstnanců byla negramotná, což odpovídalo jejich nízkému společenskému postavení. Pak ale musíme přepokládat, že pravděpodobně většina $\mathrm{z}$ nich ani nevěděla, co v př́ípadném písemném záznamu o jejich pracovním poměru je ve skutečnosti napsáno. Stejně tak je iluzorní předpokládat, že by ze své pozice mohli v dobových reáliích tehdejšího světa cokoli vymoci žalobami proti svému zaměstnavateli. Výše uvedený prŕpad z Digest je tak pochopitelně naprostou výjimkou. ${ }^{34}$

Za doplnění ale stojí i zmínka o přerodu antického světa do světa středověkého. S postupně se prosazujícím křest'anstvím se vztah zaměstnance a zaměstnavatel pozvolna ocital v pozměněném kontextu. Jde především o autoritu Bible, resp. církevních autorit, odvolávajících se na Bibli. Asi nejčastěji citovaný výrok, zaznamenaný v Bibli v tomto směru, zní „hoden je dělník své mzdy“. ${ }^{35}$ Lze však najít i ostřejší a konkrétněji formulované výroky, jako je např. „hle, mzda dělníků, kteří žali vaše pole, a vy jste jim ji upřeli, volá do nebes, a křik ženců pronikl ke sluchu Hospodina zástupư‘. ${ }^{36}$ Zaměstnavatel se tak ocital pod větším tlakem - nikoli však právním, ale společensko-náboženským, nutno konstatovat.

\section{ZÁVĚR: VÝZNAM LOCATIO CONDUCTIO PRO OBLAST PRACOVNÍHO PRÁVA}

Již jsme uvedli důvody, proč locatio conductio operarum nenabyla v římské společnosti zásadního významu, resp. požívala daleko menší důležitosti a subtilnější právní úpravy než je tomu u pracovní smlouvy v současnosti. Potřeba pracovní síly se uspokojila množstvím otroků, př́padně rodinných př́slušníků ${ }^{37}$ nebo propuštěnců,

33 Císař Septimius Severus vládl v letech 193-211 n. 1.

34 Viz např. BRUNT, P. A. Free Labour and Public Works at Rome, The Journal of Roman Studies, 1980, 70, s. 90 .

$35 \mathrm{~L} 10,7$.

36 Jak $5,4$.

37 JOLOWICZ - NICHOLAS, c. d., s. 163. 
některé z prací byly také vykonávány v podstatě jako čestná zaměstnání bezplatně, resp. pouze s možností ,dobrovolné“ odměny (honorarium), a př́pady spojené se zaměstnáváním se k římským právníkům ani nedostaly, nebot' ti se zpravidla pohybovali ve vyšších společenských kruzích. Proto zaměstnávání na základě locatio conductio operarum zdaleka nedosahovalo takové frekvence zmínek v kazuistických př́ípadech římské jurisprudence.

Přes to všechno i v tomto odvětví rímské právo zasadilo jisté základy právní úpravy a můžeme spatřovat určité shodné hlavní znaky i s platným právem, především co se týče vzájemnosti práv a povinností zaměstnance a zaměstnavatele, nutnosti osobního výkonu práce zaměstnancem, úvah o odměňování (odměna je jednou z podstatných náležitostí locatio conductio operarum a jedním z definičních znaků závislé práce v platném právu), odpovědnosti zaměstnance či moderní terminologií řečeno překážek v práci, atd.

Na závěr lze pro zajímavost uvést př́klad vývoje v Jihoafrické republice, kde byl pracovněprávní vztah upraven principy odvozenými z Roman-Dutch Law, konkrétně od obchodní smlouvy o nájmu a pronájmu, a to až do roku 1841, prričemž tato úprava vykazovala společné znaky s výše popsanou locatio conductio operarum. ${ }^{38}$

\author{
JUDr. David Falada, Ph.D., Mgr. Kamila Stloukalová \\ Právnická fakulta Univerzity Karlovy \\ Katedra právních dějin \\ falada@prf.cuni.cz, stloukalova@prf.cuni.cz
}

38 CONRADIE, M. The Constitutional Right to Fair Labour Practices: A Consideration of the Influence and Continued Importance of the Historical Regulation of (Un)Fair Labour Practices Pre-1977. Fundamina, 2016, vol. 22, Nr. 2, s. 164. 



\title{
PRÁVNÍ POSTAVENÍ SPORTOVNÍCH TRENÉRŮ V ČESKÉ REPUBLICE
}

\author{
DAVID KOHOUT*
}

\begin{abstract}
Legal Position of Sport Coaches in the Czech Republic
This article seeks to review the legal position of sport coaches in the Czech Republic. It examines the general legal framework for their activity in terms of the applicable public and private law regulation. More specifically it looks into the contractual basis of their relationship with sport clubs and individual athletes, which is very variable in terms of the types of contracts used under the Czech law and usually using other types of contracts than employment contract. The reason for this can seen principally in the absence of specific sport-based type of contract, which would be foreseen for such legal relationships in the Czech Republic (in contrast to a number of other countries, which adopted legislation in this respect). From another perspective, this article also discusses the impact of internal regulation of sport associations on the performance of coaches' duties in the respective sport discipline. This regulation also has significant impact on the coaches as it governs the system of their licencing and thus sets out eligibility criteria for exercising their profession.
\end{abstract}

Keywords: coach; sports law; sport; sports contracts

Klíčová slova: trenér; sportovní právo; sport; smlouvy ve sportu

DOI: $10.14712 / 23366478.2019 .3$

\section{ÚVODNÍ PŘEDZNAMENÁNÍ}

Z hlediska společenského a mediální vnímání sportu se zdá být obsazení pozice trenéra nejen $\mathrm{v}$ kolektivních sportech jednou z klíčových premis cesty za sportovním úspěchem. Trenér má ve sportu ${ }^{1} \mathrm{v}$ obecné rovině přispívat $\mathrm{k}$ rozvoji výkonnosti sportovců a tím pomoci dosáhnout i kolektivních zájmů jejich sportovních klubů prostřednictvím těchto, $\mathrm{v}$ daných klubech, oddílech či střediscích, registrovaných

* JUDr. David Kohout, Ph.D., je vedoucím oddělení pro zahraniční styky Právnické fakulty Univerzity Karlovy, vědeckým pracovníkem Centra mimosoudního řešení sporů tamtéž a členem Sboru rozhodců Fotbalové asociace Ceské republiky.

1 Srov. též dokument Ministerstva školství, mládeže a tělovýchovy: Přehled odborností pro žadatele o akreditaci vzdělávacím zařízení v oblasti sportu. Dostupné online na: <http://www.msmt.cz/file/48228/>. [cit. 31. 10. 2018]. 
sportovců. ${ }^{2}$ Těmito kolektivními zájmy je ve smyslu obecného soutěživého ${ }^{3}$ rozměru sportu především prezentace jména vlastního klubu/oddílu 4 (popř. v rámci sportovní reprezentace vlastního státu) a zvýšení jeho popularity jakožto moderní alternativy středověkých a raně moderních ideálů slávy na poli válečném a milostném.

Velmi trefně toto vystihuje M. Colucci, když píše: „Mají neskutečnou odpovědnost za posouvání svého týmu k úspěchu. Motivuji hráče a pomáhaji jim naplno rozvinout svioj talent, uči je fotbalové dovednosti a pomáhaji hráčùm maximalizovat jejich talent a vybrousit virtuozitu těch nejlepšich hráču. Jsou společenskými vzory a jako takoví maji důležitý vliv na chování hráčů jak na hřišti, tak mimo něj. "5

Tento text si však klade za cíl představit pozici sportovních trenérů z ryze pragmatického pohledu právního rámce jejich fungování pro jednotlivé sportovní organizace v kontextu smluvního rámce této činnosti a specifik sportovního prostředí v České republice. Je zde nutné míti na paměti, že trenérská činnost se v dnešní době realizuje v celé řadě forem. Trenéŕi působí u klubů či reprezentačních výběrů věnujících se kolektivním sportům i sportům individuálním. Tréninková činnost se uskutečňuje $\mathrm{v}$ př́padě sportovců, kteří se účastní soutěží organizovaných zastřešující organizacíb i v př́ípadě sportovců, kteří mají ryze osobní výkonnostní ambice mimo účast na sportovních utkáních či soutěžích 7 . Podporují sportovce na ryze amatérské úrovni, kdy vykonávají svou činnost na dobrovolnické a mnohdy smluvně blíže neregulované bázi. Jsou však i trenéři, kteří za svou činnost od klubu získávají dílčí odměnu, avšak hlavním zdrojem jejich př́ijmu je činnost zcela jiná. Na nejvyšší úrovni se pak můžeme setkat s osobami, které výkon „trenérského řemesla“ mají jako hlavní zdroj svých př́imů a jedná se tak v jejich podání o profesionální výkon trenérství. Všechny tyto modality je možné uchopit po stránce obecného právního rámce pro jejich uskutečňování, stejně jako z pohledu př́ipadné interní regulatoriky sportovních odvětví, která nezřídka mají vlastní doplňující předpisy pro podmínky výkonu trenérské činnosti v př́slušném sportu.

2 Sportovcem příslušejícím ke sportovnímu klubu můžeme rozumět podle $§ 2$ odst. 3 zákona č. 115/2001 Sb., o podpoře sportu, především „,každou fyzickou osobu, která v daném kalendárním roce skutečně vykonává sportovni ćinnost, pro kterou je u sportovni organizace evidována“.

3 V dnešní době však postupně více a více komercionalizovaného rozměru sportu.

4 Termín oddíl je v tomto smyslu uživán pro složku klubu zpravidla bez vlastní právní subjektivity, který je organizačně vyčleněn v rámci vnitřní struktury klubu. Př́íkladem může být např. Tělovýchovná jednota Turnov, z. s., která v rámci jednotné právnické osoby (spolek podle § 214 a násl. zákona č. 89/2012 Sb., občanský zákoník - dále jen „OZ“) uvádí v rámci své vnitřní struktury 20 různých oddílů pro jednotlivé sporty - např. aerobik, box, florbal, musherství. Jiným případem mohou být sportovní oddíly, které jsou od svého mateřského klubu právně odvislé ve formě tzv. pobočných spolků podle $§ 228$ a násl. OZ. V takovém príípadě sice disponují oddíly vlastní právní osobností, ale jsou ve své existenci právně závislé do značné míry na svém „hlavním spolku“. Jako příklad mohou sloužit jednotlivé sokolské jednoty, které jsou sice odvislé od celostátní České obce sokolské, ale mají vlastní právní osobnost - např. Tělocvičná jednota Sokol Vsetín, pobočný spolek.

5 COLUCCI, M. Foreword. In: VANDELLÓS ALAMILLA, J. F. Football Coach-related Disputes. A Critical Analysis of the FIFA Players 'Status Committe Decisions and CAS Awards. B. n.: Sports Law and Policy Centre, 2018, s. 11.

6 Zastřešující organizací je míněna sportovní asociace (ve sportovní praxi vždy spolek), at' již se jedná o asociaci typicky na úrovni celostátní (napřr. Fotbalová asociace České republiky - dále jen „FAČR“), či úrovni mezinárodní (nap̌r. Union of European Football Associations - dále jen „UEFA“), která organizuje podle vlastních herních a soutěžních pravidel př́slušnou soutěž.

7 Viz např. fitness trenéři. 
V české odborné literatuře již bylo poměrně hodně napsáno o právním postavení aktivních sportovců s přihlédnutím $\mathrm{k}$ historickému i současnému právnímu stavu v kontextu soudní rozhodovací praxe, a to především v oblasti kolektivních sportů. ${ }^{8}$ Právnímu postavení sportovních trenérů však doposud nebyla věnována ucelená pozornost. ${ }^{9}$ Jejich postavení je oproti aktivním sportovcům v praxi českého sportu rozmanitější, i když hlavní principy jejich faktického fungování jsou do značné míry nakonec obdobné. Jedním z podstatnějších rozdílů může být především interní regulace pro činnost sportovních trenérů z hlediska sportovních asociací, např. licencování těchto osob. V České republice však, na rozdíl od právní úpravy (velké většiny) evropských zemí, nefunguje systém centrální státní registrace trenérů jako zvláštní státem uznávané kategorie regulovaných „sportovních odborníkü“.

\section{SPORTOVNÍ TRENÉŘI V ČESKÉ REPUBLICE Z HLEDISKA OBECNÉHO PRÁVNÍHO RÁMCE JEJICH ČINNOSTI}

Právní řád České republiky s pojmem „sportovní trenér“ operuje jen v omezeném rozsahu a nikde jej nedefinuje. $Z$ kontextu je však zřejmé, že z pohledu právní úpravy je profese trenéra zohledňována spíše jen jako kategorie ekonomické činnosti. Základní právní předpis, který je v České republice zaměřen specificky na oblast sportu, tj. zákon o podpoře sportu, je spíše jen jakousi kompetenční normou veřejnoprávního charakteru. ${ }^{10}$ Ve svém $\S 1$ a obecně proklamativně stanovuje, že ,základními prioritami v oblasti sportu je podpora sportu dětí a mládeže a jejich trenérů a podpora sportovnich reprezentantů České republiky", a v dalších ustanovení obecně ukládá Ministerstvu školství, mládeže a tělovýchovy vytvářet vhodné podmínky především pro činnost trenérů dětí a mládeže. Funkci trenéra zmiňuje zákon dále již jen v kontextu připravovaného „rejstřiku sportovních organizací žádajicích o podporu ze státního rozpočtu podle § 6 b nebo 6 c a sportovcü, trenéru a sportovních zařizení, na jejichž činnost se žádá o poskytnutí této podpory“ (§ 3 odst. 1 písm. j)). ${ }^{11} \mathrm{~V}$ současné době

8 Srov. zejména PICHRT, J. (ed.). Sport a (nejen) pracovní právo. Praha: Wolters Kluwer, 2014; JURKA, H. Právní úprava profesionálního sportu v České republice a v zahraničí. Praha: Wolters Kluwer, 2018.

9 Srov. např. i jejich úplné opomenutí ve výčtu fyzických osob vyskytujících se v oblasti sportu: KUBÍČEK, J., Sport a právo, s. 99. Dostupné online na: <https://is.muni.cz/el/1451/podzim2013/np2330 /um/44387142/0_Sport_a_pravo_2c_skripta_2c_Jiri_Kubicek_2c_2012.pdf > [cit. 31. 10. 2018].

10 Zákon č. 115/200̄ $1 \mathrm{Sb}$., o podpoře sportu.

$11 \mathrm{Tj}$. v rámci výzev dotačních programů Ministerstva školství, mládeže a tělovýchovy je možné žádat též o prostředky za účelem podpory trenérů ve sportovních klubech (na neprofesionální úrovni), popř. pro účely zajišsění sportovní reprezentace České republiky. K tomuto je možno pro bližší osvětlení využít citaci z důvodové zprávy k návrhu novely zákona o podpoře sportu z roku 2018 (sněmovní tisk č. 241/0): „Oproti dosavadnímu zněni zákona o podpoře sportu nedocházi k rozšíreni účelu, ke kterému má být dotace na podporu sportu sportovním organizacím poskytována. S ohledem na existujici interpretační problémy se navrhuje pouze upresnit, že výdaji na podporu sportu, na něž může být agenturou dotace poskytnuta, jsou oprávnèné výdaje na činnost sportovnich organizací spojené s podporou sportu zaměrenou zejména na podporu sportu dětí a mládeže, sportu pro všechny, sportu zdravotně postižených osob a na podporu úspěšných sportovnich reprezentantů České republiky, tedy prioritami v oblasti sportu stanovenými zákonem o podpoře sportu. Druhové rozlišení oprávněných výdajů na činnost sportovnich organizací stanoví agentura v programech, na základě kterých bude podporu v oblasti sportu poskytovat. Typicky se pritom 
projednávaný návrh novely zákona na podporu sportu (sněmovní tisk č. 241/0 z roku 2018) na tomto opomíjejícím prrístupu nic nemění, uvedené pravomoci Ministerstva by „pouze“ měly přejít na nově vytvářenou Národní sportovní agenturu.

Český př́stup je v ostrém kontrastu k úpravě trenérské profese na Slovensku, kde byla vtělena do zvláštní zákonné úpravy zákona č. 440/2015 Z. z., o športe. Podle něj se sportovní trenér počítá za tzv. „sportovniho odborníka“ (§ 6 odst. 1 písm. a)), který má tuto pozici oprávnění zastávat teprve okamžikem zápisu do veřejného „registru osob ve sportu“. 12 Podobně jako v České republice, jak bude dále podrobněji rozvedeno, počítá však slovenská úprava s mnohostí právních forem výkonu takto registrované trenérské činnosti. Jedná se o tyto modality: výkon činnosti na základě živnostenského oprávnění, na základě smlouvy o výkonu činnosti sportovního odborníka, na základě pracovněprávního vztahu či jiného pracovněprávního vztahu, jako dobrovolník či zcela bez smluvního základu (§ 6 odst. 3).

Z tohoto výčtu se českýma očima jeví jako nejzajímavější úprava smlouvy o výkonu činnosti sportovního odborníka, jež je jako specifický smluvní typ zákonem o športe $\mathrm{v} \S 49 \mathrm{a}$ upravována. ${ }^{13}$ Předepisována je pro ni písemná forma s tím, že jejími podstatnými náležitostmi jsou stanovení druhu činnosti (v tomto našem případě trenérské, druhů sportovních odborníků je však více), odměny a doby, na níž je smlouva uzavírána. Ta může činit maximálně 12 měsíců, s možností opětovného uzavření smlouvy (bez omezení počtu opakování, což může být podstatným znakem odlišujícím tento smluvní typ od pracovněprávních vztahů na dobu určitou ${ }^{14}$ ). Maximální počet hodin, které může sportovní odborník podle tohoto typu smlouvy pro klub vykázat, je 30 hodin týdně a 12 hodin $\mathrm{v}$ průběhu 24 po sobě jdoucích hodin. Tento typ smlouvy také obsahuje zákaz zahrnutí konkurenční doložky pro dobu po skončení platnosti smlouvy, kterou je možno ukončit dohodou či výpovědí se standardní výpovědní dobou 15 dní od písemného doručení výpovědi, není-li ve smlouvě ujednán i jiný možný způsob ukončení smlouvy. Na smlouvu se pohlíží jako na tzv. jiný pracovněprávní vztah ve smyslu $§ 1$ odst. 3 zákoníku práce, z nějž se enumerativním výčtem na smlouvu o výkonu činnosti sportovního odborníka vztahují některá ustanovení (o minimální mzdě, ochraně při práci a dále vybraná ustanovení z úpravy dohod uzavíraných mimo pracovní poměr - především obecné vzájemné povinnosti smluvních stran a odpovědnost za způsobenou škodu).

Slovenský zákon také dává výslovné oprávnění národním sportovním svazům, aby pro sportovní odborníky (v tomto prŕípadě trenéry) předepisovaly požadované podmínky odborné způsobilosti, v což můžeme jistě zahrnout i vnitřní svazové systémy licencování či proškolování trenérů na různých úrovních (§ 16 odst. 2 písm. i)). Obsah školení trenéru je pak dále prohlubován $\mathrm{v} \S 83$, kde se pro trenéry určuje 5 různých kvalifikačních stupňủ, jež mohou získat cestou vzdělávacích programů poskytovaných školskými subjekty či sportovními svazy.

bude jednat o úhradu nákladi̊ spojených se zajištěním trenérů, rozhodčich, dopravy na sportovní utkání apod."

12 Nad tento rámec zná zákon o športe např. i kategorii ,instruktor športu“ jakožto zvláštní druh sportovního odborníka (§ 6 odst. 1 písm a)).

13 K smluvním vztahům ve sportu na Slovensku obecně srov. § 31 a násl. zákona č. 440/2015 Z. z.

14 Srov. § 48 zákona č. 311/2001 Z. z., zákonník práce. 
Jak již bylo uvedeno výše, v České republice v současnosti žádná výslovně stanovená legislativní vodítka k právnímu rámci fungování trenérů nenalezneme. Bylo a je tudíž ponecháno na právní praxi, jak vztahy mezi trenéry a sportovními kluby či dalšími subjekty uspořádá. Situace je tak ne nepodobná úpravě postavení aktivních sportovců v celém spektru jejich možných postavení. Lze proto souhlasit s J. Kubíčkem, když uvádí, že „vzájemné vztahy mezi sportovními subjekty vykazují velkou míru autonomie podobně jako právní úprava postaveni sportu. Pro značnou rozmanitost jednotlivých vztahů (kolektivni sporty / individuálni sporty), postavení sportovců (profesionál / poloprofesionál / amatér), charakter vztahů (osobni / obchodni) nebo délku vztahů (smluvni dlouhodobé - hráčské / pro jednotlivou akci-pořadatel, rozhodči) je tato oblast velmi členitá. "15

Z pohledu sportovců se totiž setkáme v České republice se situací, která, dá se ř́ci, překlenuje legislativní vakuum dlouhodobou praxí posvěcenou soudními rozhodnutími. V kolektivních sportech se historicky setkáváme s tím, že sportovci vykonávají svou činnost pro klub nikoliv ve formě zaměstnanců, nýbrž ve formě osob samostatně výdělečně činných. Hlavní důvody, které $\mathrm{k}$ tomu vedou, lze $\mathrm{v}$ krátkosti shrnout takto: systém odměňování za sportovní výkony je mnohdy odvozen od sportovních výsledků a obsahuje systému smluvních bonusů či naopak malusů, s čímž standardní pracovněprávní úprava nepočítá; problematika „pracovní doby“ u sportovců je vysoce variabilní a vymyká se pracovněprávnímu standardu; špatná využitelnost stávající úpravy řetězení pracovních smluv na dobu určitou; problematika výpovědních důvodů podle pracovního práva, která pro oblast sportu mimo jiné znevýhodňuje př́ípadného zaměstnavatele, jemuž by mohl dát hráč kdykoliv výpověd', byt' do jeho angažování třeba klub na přestupovém trhu investoval nemalé finanční prostředky. ${ }^{16} \mathrm{~V}$ neposlední řadě se ze sportovních kruhů ozývá, že podřazení sportovců pod zaměstnanecký režim by přineslo klubům nemalé finanční obtíže vzhledem k zvýšeným nákladům na pojistné odváděné za zaměstnance zaměstnavatelem. ${ }^{17}$ To vše vedlo praxi $\mathrm{k}$ jiné cestě úpravy smluvních vztahů $\mathrm{v}$ kolektivních sportech než cestou smluv podle zákoníku práce.

Lze mít za to, že judikatura českých soudů posvěcující v oblasti výkonných sportovců $\mathrm{v}$ kolektivních sportech tento stav je odborné veřejnosti poměrně známá. Vůdčím rozsudkem pak zřejmě je rozsudek Nejvyššího správního soudu ze dne 29. 11. 2011, spis. zn. 2 Afs 16/2011, v němž soud shledal následující:

„Činnost sportovce se pojmovému vymezeni závislé ćinnosti sice velmi bliží, nicméně nedosahuje její intenzity. Jakkoliv se totiž stěžovatel musel při své činnosti ř́dit pokyny svého smluvního partnera (klubu - ,zaměstnavatele') a měl právo od něj dostávat př́-

15 KUBÍČEK, c. d., s. 133.

16 Srov. k tomuto např. STÁDNÍK, J. Sportovní činnost a závislá práce. In. PICHRT, c. d., s. 80-82; či GREGUŠ, J. Vyváženost’ práv a povinností medzi športovou organizáciou a športovcom v zákone o športe. In: BARANCOVÁ, H. - OLŠOVSKÁ, A. (eds.). Súčasný stav a nové úlohy pracovného práva. Praha: Leges, 2016, s. 367-369.

17 PICHRT, J. Profesionálni sportovec zaměstnancem? In: PICHRT (ed.). c. d., s. 16. S tímto je nyní konfrontován sportovní sektor na Slovensku, kde by k 1. 1. 2019 měly být za zaměstnané sportovce kluby odváděny odvody na pojištěné v plné výši. K situaci na Slovensku a obavám spojeným s touto otázkou srov. SEPEŠI, P. Závery okrúhleho stola $k$ téme odvodov profesionálnych športovcov - zamestnancov. Záznam a závěry diskuze v rámci kulatého stolu na konferenci „Šport a právo 2018“. Dostupné online na: $<$ http://www.ucps.sk/Zavery_okruhleho_stola_k_teme_odvodov $>$ [cit. 31. 10. 2018]. 
slušnou sjednanou odměnu, zejména v povinnosti sportovce vykonávat práci ,v pracovni době nebo jinak stanovené nebo dohodnuté době na pracovišti zaměstnavatele, poprípadě na jiném dohodnutém mistě je činnost profesionálního sportovce natolik specifická, že se omezením plynoucím ze zaměření a výslovné reglementace zákoníku práce vymyká. Z povahy věci je totiž zřejmé, že součástí výkonu činnosti profesionálního sportovce není pouze účast na utkáních, př́padně trénincích, svého klubu, nýbrž i řada dalšich aktivit, které jsou nezbytné jednak pro stoprocentní pripravenost daného sportovce [...] a také z di̊vodi̊ marketingových zájmů klubu (reklamní akce, autogramiády, setkání s fanoušky atp.). V konečném di̊sledku je proto obtížně představitelné, aby specifická činnost profesionálního sportovce v běžici sezóně byla svojí povahou slučitelná s takovými instituty zákoníku práce, jako jsou třeba nepřetržitý odpočinek mezi dvěma směnami, prestávky v práci na jídlo a oddech, dny pracovního klidu anebo práce přesčas. I kdyby však tato úskalí byla tvořivou aplikaci zákoníku práce překonána, je na smluvních stranách, aby i z di̊vodi̊ obtižné použitelnosti zákoníku práce na činnost stěžovatele, zvolily jinou smluvní úpravu, byla-li podle soukromého práva možná. [...] lze tak učinit dílči závěr, že činnost profesionálního sportovce není jednoduše podřaditelná pod pojem ,závislá práce“ ve smyslu zákoniku práce. Nelze proto vyloučit, resp. dokonce považovat za protiprávní, uzavírání i jiných než pracovních smluv mezi sportovci a jejich kluby. Tento závěr lze ostatně opřit i o faktickou situaci, kdy je v praxi obecně akceptováno, že profesionálni sportovec může - z daňového hlediska - působit též jako OSVČ [...]. K odklonu od této obecně akceptované praxe by proto musel existovat velmi silný di̊vod, spočívající např. ve výslovné změně zákonné úpravy. Jinak totiž lze argumentovat i prostřednictvím určité míry normativni sily fakticity."18

Tuto dlouhodobě konzistentní judikaturní linii českých soudů potvrdil a dále prohloubil i nedávný rozsudek Nejvyššího správního soudu v př́ípadu fotbalového útočníka Davida Lafaty ze dne 13. 7. 2017, spis. zn. 6 Afs 278/2016-54. Ř́zení fakticky v tomto případě rovněž jako v případě předešlého rozhodnutí vzešlo z problematiky aplikace daňových předpisů na oblast právních vztahů ve sportu. Sportovec totiž danil své př́ijmy jako osoba samostatně výdělečně činná vykonávající tuto činnost na základě živnostenského oprávnění. S tím je oproti OSVČ vykonávající tzv. svobodné povolání spojeno daňové zvýhodnění spočívající v tom, že jako živnostník si může osoba uplatňovat tzv. výdajové paušály až do výše 60 \% svých př́immů (maximálně do výše výdajů $600.000 \mathrm{Kč}$ ), zatímco v prípadě svobodných povolání je tento paušál stanoven hranicí 40 \% prŕíjmů (a maximálně do výše výdajů 400.000 Kč). ${ }^{19}$,Živnostenský model“" se tak z hlediska daňové optimalizace jeví jako výhodnější, čehož proto David Lafata využíval a byl v držení živnostenského oprávnění pro svou činnost fotbalového hráče (a nutno dodat, že takto postupuje v praxi České republiky většina profesionální sportovců nejen v kolektivních sportech).

Tento postup Davidovi Lafatovi vytkl finanční úřad v rámci daňové kontroly a uložil mu dodanit cca. 870.000 Kč a uhradit k tomu daňové penále ve výši cca. 174.000 Kč.

18 Srov. odst. 28 a 30 citovaného rozsudku.

19 Viz $§ 7$ odst. 7 zákona č. 586/1992 Sb., o daních z př́ijmu. 
Fotbalový útočník s tímto nesouhlasil a cestou opravných prostředků dospěl s tímto sporem až k Nejvyššímu správnímu soudu, jenž se v rozsudku vyjádřil následně:

„Legální definici nezávislého povolání ani výčet činností, které pod daný pojem spadaji, žádný právní predpis neobsahuje. Jak vyplývá z rozsudku Nejvyššiho správního soudu ze dne 21. 9. 2011, čj. 8 Afs 56/2010-73, č. 2571/2012 Sb. NSS, ve vztahu k obsahu tohoto pojmu lze podpưrně využit § 22 odst. 1 písm. f) zákona o danich z príjmů, $k$ de se v souvislosti s daňovými nerezidenty operuje s pojmem nezávislá činnost. Při vědomí, že některé z tam uvedených činností je třeba považovat za podnikání podle jiných právnich předpisů (architekt, lékař, inženýr, právnik), lze za nezávislá povolání považovat např. výkonné umělce, sportovce, jejich trenéry, rozhodčí, artisty apod. Pro zminěné profese je charakteristická kreativita a samostatnost při volbě způsobu, jakým bude dosaženo predem stanoveného výsledku.

Živností se dle § 2 živnostenského zákona rozumí, soustavná činnost provozovaná samostatně, vlastním jménem, na vlastni odpovědnost, za účelem dosažení zisku a za podminek stanovených tímto zákonem : Aby byla určitá činnost živností, je nutné kumulativni naplněni všech uvedených podmínek. Nelze přehlédnout, že uvedená definice se do značné miry překrývá s definici podnikáni dle § 2 odst. 1 obchodního zákoniku. S určitou mírou zjednodušení je tedy živností podnikání za podminek stanovených živnostenským zákonem. Dle přilohy č. 4, bodu 74 nařizení vlády č. 278/2008 Sb. je obsahem náplně živnosti volné ,Provozováni tělovýchovných zařizení a organizování sportovní činnosti ' mimo jiné též , [č]innost výkonných sportovcü, prípadně rozhodčich, provozovaná samostatně a za účelem dosažení zisku'. V§ 3 živnostenského zákona je uveden taxativní výčet činností, které nejsou živnostmi, přestože svým obsahem mohou naplňovat všechny znaky podnikání. Jedná se zejména o činnosti, jejichž výkon je regulován zvláštními právními předpisy. Činnost výkonných sportovcù v tomto výćtu zahrnuta není. [...] Nejvyšši správní soud je toho názoru, že pokud je s ohledem na neujasněnost právní úpravy v zásadě možné vykonávat samostatnou činnost profesionálního sportovce dle $\S 7$ zákona o danich z př́jmů bud'to jako živnostenské podnikání, nebo jako nezávislé povolání, nelze za daného právního stavu daňový subjekt nutit, aby zvolil ten zpưsob, kterýje vhodnějši z hlediska fiskálnich zájmů státu."20

Na tomto základě je tak dále petrifikována stávající praxe sportovců, kteří se živí podáváním sportovních výkonů ve prospěch klubů, přičemž je nově soudy napevno dáno i to, že v rámci kategorie OSVČ se připouští obě myslitelné varianty, tj. včetně daňově výhodnější varianty s živnostenským oprávněním.

Úpravě právního postavení hráčů byla $\mathrm{v}$ tomto příspěvku věnována výše rozsáhlá pozornost $\mathrm{z}$ toho důvodu, že praxe $\mathrm{v}$ př́ípadě trenérů je velmi podobná, avšak není $\mathrm{k}$ ní dostupná takto poměrně ucelená judikatura. Závěry soudů o principu smluvní volnosti ve vztahu k volbě druhu smluvního vztahu je nutné brát mutatis mutandis za obecně platné i pro výkon „trenérského řemesla“ v naší zemi. Jistě není důvod uvažovat, že trenérství je výrazně odlišné od principů fungování profesionálních sportovců, co se jejich vztahu s klubem týče.

20 Srov. odst. 28, 29, 35 citovaného rozsudku. 
Z hlediska smluvního lze tudíž v př́ípadě trenérů a jejich kontraktačních partnerů, tj. v našem uvažovaném prŕpadě nejčastěji klubů, v prŕípadě individuálních sportů ovšem i jednotlivců jakožto profesionálních sportovců v tenise, lyžování apod., hovořit o široké smluvní volnosti.

V profesionálním a poloprofesionálním sportu se budeme nejčastěji setkávat s trenérskou činností v režimu OSVČ, a to zpravidla se živnostenským oprávněním (volná živnost, srov. výše citaci z rozsudku Nejvyššího správního soudu spis. zn. 6 Afs 278/2016-54). Smluvním základem, jímž jsou tito trenéři vázáni ke klubům či individuálním sportovcům, bude nejčastěji inominátní smlouva podle $\S 1746$ odst. 2 OZ. ${ }^{21}$ Dalším smluvním typem, se kterým je možno se eventuálně též setkat a jenž připouští i judikatura, je smlouva příkazní (dříve též mandátní). ${ }^{22} \mathrm{Z}$ povahy věci nepůjde u trenérských př́kazních smluv vykonávat činnosti pro př́kazce jinak než osobně, snad s výjimkou toho, že může být dáno oprávnění trenéra některé činnosti delegovat např. na své asistenty.

Forma činnosti trenéra jako OSVČ však není pochopitelně jedinou, kterou můžeme v mnohoúrovňovém sportu v České republice najít. Nepochybně se lze setkat dokonce i s variantami, že v rámci jednoho a toho samého sportovního klubu působí někteří trenéři např. na základě inominátní smlouvy, zatímco jiní trenéři budou vykonávat své povinnosti třeba na základě dohody o provedení práce či dohody o pracovní činnosti. Dohody o pracích konaných mimo pracovní poměr jsou v praxi sportovních klubů relativně hojné na nižších úrovních soutěží, které z důvodů ekonomických i výkonnostních neumožňují či nevyžadují angažování trenéra v plném rozsahu. Klasický pracovní poměr se $\mathrm{v}$ př́padě trenérů $\mathrm{v}$ praxi nevyskytuje $\mathrm{s}$ ohledem na obdobné omezující skutečnosti, jež byly vypočteny výše ve vztahu k hráčským smlouvám.

Z hlediska smluvního zakotvení činnosti trenéra je vhodné dbát v praxi na to, aby byly dostatečně uspokojivě formulovány především podmínky skončení právního vztahu klubu a trenéra. V tuzemských poměrech vrcholných soutěží je spiše výjimkou, aby trenér na své pozici vydržel po celou dobu předvídanou ve smlouvě. Obvykle jsou trenéři tzv. odvoláni z důvodu neuspokojivých soutěžních výsledků mužstva, v některých případech ale může dojít i $\mathrm{k}$ předčasnému ukončení $\mathrm{z}$ důvodu angažování kouče na trenérskou lavici některého prestižnějšího klubu či reprezentačního výběru. Před orgány rozhodujícími spory ze smluv mezi trenéry a kluby ${ }^{23}$ je zpravidla jednou z hlavních sporných otázek otázka finančního plnění klubu vůči trenérovi k okamžiku ukončení smluvního vztahu. Lze proto doporučit, že obě strany by měly věnovat „výstupním klauzulím ze smlouvy“ zvýšenou pozornost už během předkontraktačního vyjednávání, aby tak minimalizovaly následné spory v okamžiku rozvazování smlouvy, kdy už vzájemné vztahy a možnosti racionální dohody nemusí být nejlepší. Již při uzavření smlouvy by mělo být co možná nejprecizněji ve smlouvě stanoveno, za jakých okolností

21 Tj. „Strany mohou uzavřit i takovou smlouvu, která není zvláště jako typ smlouvy upravena.“

22 Srov. nález Ústavního soudu ze dne 25. 10. 2006, spis. zn. II. US 686/05. Mandantem/př́kazcem je v takovém případě klub, pro nějž obstarává mandatár/prííkazník - trenér určité záležitosti spojené s př́ipravou sportovců.

23 V praxi jde o orgány jednotlivých sportovních svazů, popř. na mezinárodní úrovni o Mezinárodní rozhodčí soud pro sport se sídlem Lausanne (Court of Arbitration for Sport). 
může klub či trenér smlouvu vypovědět a jaké to bude mít následky. Lze zvážit vložení ustanovení o okamžitém ukončení právního vztahu, ukončení dohodou, ukončení s výpovědní dobou, práva a povinnosti stran při běhu výpovědní doby, vypověditelnost pouze k určitým termínům v roce, odstoupení atd. Zcela zásadní je v profesionálním prostředí stanovit, zda „propuštěný“ trenér bude mít nárok na vyplacení celé odměny garantované smlouvou až do jejího konce, či zda bude tato částka krácena, popř. trenérovi po předčasném skončení smluvního vztahu další plnění od klubu nepřipadne. Tím spíše je výše uvedené nutno brát v potaz vzhledem k tomu, že trenérské smlouvy v České republice nebývají pracovními smlouvami.

Znění smluv často nad tento rámec může naopak obsahovat i stanovení tzv. opčního práva klubu požadovat u trenéra přednostní prodloužení smlouvy ještě před jejím vypršením, pokud je klub s prací trenéra spokojen. V takovém př́padě je naopak vhodné již do původní smlouvy jasně specifikovat podmínky, za kterých může být opce uplatňována, zpravidla se vyžaduje, aby odměna trenérovi byla navýšena $\mathrm{v}$ řádu několika desítek procent. ${ }^{24}$

Nakonec by neměla být zapomenuta i v praxi amatérského sportu zcela zásadní rovina, kdy osoba pro klub či sportovce vykonává trenérskou činnost na ryze dobrovolné bázi a bez nároku na jakoukoliv odměnu. $V$ takovém případě neexistuje mezi subjekty ani uzavřená písemná smlouva, ledaže by např. trenér byl členem daného sportovního spolku, což lze považovat za specifický formální smluvní vztah. ${ }^{25} \mathrm{~V}$ př́ípadě zvláštních situací (např. odpovědnost za škodu, ukončení činnosti trenéra) by bylo nutno přihlédnout k obecnému soukromoprávnímu rámci pro jakékoliv jiné oblasti lidské činnosti či eventuálně $\mathrm{k}$ právům a povinnostem člena spolku daného př́slušnými stanovami sportovního klubu.

\section{INTERNÍ REGULACE ČINNOSTI TRENÉRŮ V RÁMCI SPORTOVNÍCH ASOCIACÍ}

Jak bylo základně vymezeno již v úvodní pasáži této stati, činnost sportovních trenérů bývá nezř́ídka nad rámec obecného právního řádu (resp. přesněji řečeno v limitech jeho dispozitivnosti) dále regulována uvnitř sportovních asociací. Trenérská činnost $v$ jejich sféře vlivu, tj. v příslušném sportovním odvětví, které daná asociace spravuje, je dále usměrňována jak interními normativními předpisy, tak také např. nezávaznými metodickými pokyny. Pokud projdeme strukturu orgánů a odborných komisí sportovních svazů některých nejpopulárnějších sportů v České republice, nalezneme u řady z nich tzv. trenérské komise. ${ }^{26}$ Jejich oprávnění navazují obvykle na stanovy či na jejich základě přijímané interní předpisy svazů.

24 Srov. Rozhodnutí CAS 2014/A/3852 Ascoli Calcio 1898 S.p.A v. Papa Waigo N'diaye \& Al Wahda Sports and Cultural Club ze dne 11. 1. 2016. Dostupné online na: <http://jurisprudence.tas-cas.org/Shared\%20 Documents/3852.pdf> [cit. 31. 10. 2018].

25 Založeného na přihlášce za člena spolku a následném rozhodnutí orgánu spolku o přijetí za člena spolku.

26 Např. Trenérská komise Českého svazu ledního hokeje; v rámci FAČR je možno nalézt tzv. Úsek trenérsko-metodický jako součást Sportovně-technického oddělení; v rámci UEFA má danou oblast na starosti 
Tyto interní předpisy a z nich plynoucí požadavky na výkon činnosti trenéra jsou závazné pro kouče $\mathrm{v}$ tom rozsahu, $\mathrm{v}$ jakém neodporují obecně platným právním pravidlům. Jelikož trenérské smlouvy mnohdy obsahují přímý odkaz na závaznost pravidel př́slušné sportovní asociace pro daný právní vztah mezi trenérem a klubem, lze uvažovat v tomto smyslu o jakési ,inkorporační klauzuli“, která interní normativní rámec sportovní asociace vtahuje do obsahu vzájemných práv a povinností mezi stranami takovéto smlouvy. Obecně to platí více pro prípady smluvních vztahů hráčů a klubů, které přeci jen bývají sportovními asociacemi více regulovány ${ }^{27}$, ale též pro trenérské smlouvy mohou být některé asociační regule podstatné.

Výše uvedené je relevantní nejen pro utvrzení vzájemných práv a povinností mezi kluby a trenéry, ale v jistém směru i pro vztah trenéra vůči sportovní asociaci. Dalším podstatným prvkem činnosti trenéra $\mathrm{v}$ odvětvích regulovaných do větší či menší míry zastřešujícími sportovními asociacemi je totiž i mandatorní členství trenéra $\mathrm{v}$ této asociaci - spolku. Vázanost člena spolku vnitřními pravidly této právnické osoby v nejširším slova smyslu plyne již z § 233 odst. $2 \mathrm{OZ}$, povinnost člena podřídit se interním spolkovým pravidlům a rozhodnutím spolkových orgánů však bývá standardně zakotvena též ve stanovách těchto právnických osob.

Jako př́klad je možno vzít interní rámec fungování FAČR, která ve svých stanovách $^{28}$ určuje, že trenéři jsou tzv. členy se zvláštními členskými právy a povinnostmi (čl. 9 odst. 4 písm. b) stanov). Členem FAČR se s těmito zvláštními právy a povinnostmi stává fyzická osoba mající již členství ve FAČR ,na základě ziskání trenérské licence v souladu s Řádem trenérư s tím, že tento její zvláštni status vzniká okamžikem, kdy je získání trenérské licence vloženo do centrální evidence členství."29

Výkon funkce trenéra především na nejvyšších úrovních př́islušných sportů (tj. na úrovni výkonnostního či profesionálního sportu) je obvykle vázáno na získání určité formální licence udělované sportovním svazem na základě jeho standardů či standardů daných nadřazenou mezinárodní asociací př́slušného sportu.

V př́ípadě největšího českého sportovního svazu, co se členské základny týče, FAČR, je hlavním interním předpisem pro činnost trenérů aktuálně platný Řád trenérů Fotbalo-

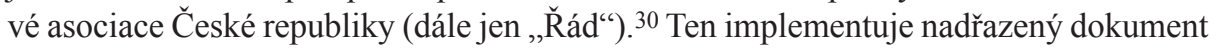
UEFA, kterým je Konvence o vzdělávání evropských trenérů UEFA (dále jen „Konvence“), k níž se FAČR přihlásila. ${ }^{31}$ Rád FAČR na tuto Konvenci totiž výslovně odkazuje

Development and Technical Assistance Committee; mezinárodní hokejová federace IIHF zase zř́dila Coaching Committee.

27 Viz poznámka pod čarou č. 41.

28 Stanovy FAČR účinné ke dni 1. 8. 2018. Dostupné online na: <https://facr.fotbal.cz/uredni-deska-predpisy /206? category $=1>$ [cit. 31. 10. 2018].

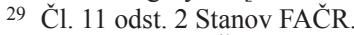

30 Aktuální znění Řádu trenérů je účinné od 1. července 2017. Dostupné online na: <https://facr.fotbal.cz /uredni-deska-predpisy/179? category=1> [cit. 31. 10. 2018].

31 UEFA Coaching Convention ze dne 4. prosince 2014. Tuto „konvenci“ přijal Výkonný výbor UEFA (Executive Committee) a jde o specifický vnitrospolkový nástroj UEFA: není pro členy UEFA bezprostředně závazný, pokud se sami nerozhodnou $\mathrm{k}$ němu přistoupit, jedná se tedy o určitou paralelu $\mathrm{k}$ instrumentům smluvního práva v klasickém mezinárodním právu veřejném $\mathrm{s}$ tím rozdílem, že $\mathrm{v}$ tomto př́ípadě se universum subjektů, kterých se může takováto „konvence“ týkat, vyčerpává s počtem členských národních fotbalových asociací UEFA (v současnosti UEFA sdružuje 55 těchto asociací). UEFA Coaching Conven- 
ve svém čl. 1 odst. 3 , lze tak dovozovat, že i s ohledem na obecné principy sportovního/ spolkového práva a tzv. pyramidální strukturu sportovních odvětví bude Konvence sloužit jako rozšiřující výkladový a aplikační rámec Řádu. V př́ípadě, že by ustanovení Rádu nebyla v souladu s ustanoveními této Konvence, podobně jako v př́ípadech jiných spolkových pravidel FAČR by bylo možné domáhat se přímé aplikace nadřazeného předpisu UEFA.

Toto obecné pravidlo fungování národních sportovních spolků ve vztahu k regulativní pravomoci nadřazených mezinárodních sportovních asociací lze v případě FAČR dovozovat mimo jiné i z prŕmého závazku v čl. 4 odst. 1 jejích Stanov, v němž se uvádí, že FAČR ,je členem FIFA a UEFA. Na tomto základě plně respektuje jejich predpisy, které jsou pro ni závazné, a zajištuje respektováni těchto predpisů svými členy cestou vydávání svých vnitřnich predpisü." 32

$\mathrm{S}$ ohledem na omezený rozsah tohoto článku i skutečnost, že v jiných sportech se může dílčím způsobem úprava výkonu trenérské funkce lišit, bude na tomto místě dále poukázáno pouze v krátkosti na hlavní principy regulace vtělené do Řádu FAČR.

Cílem tohoto vnitrospolkového předpisu je v nejširším slova smyslu „vzdělávání trenérů tak, aby bylo možno ziskat, zachovat a zvyšovat odbornou způsobilost trenérů $k$ dosažení co možná nejkvalitnějšího tréninkového procesu a pozitivního vývoje ve výkonnosti hráču. “"33 Za tímto účelem Rád nastavuje systém trenérských licencí jako podmínku výkonu trenérské činnosti v soutěžích organizovaných pod FAČR. ${ }^{34}$ Licence je oprávněna udělovat FAČR bud' samostatně (v př́ípadě nejvyšších typů licencí), popř. tuto agendu částečně delegovala na tzv. okresní a krajské fotbalové svazy, které v českém fotbalovém prostředí působí ve formě pobočných spolků FAČR ve smyslu $§ 228$ a násl. OZ.

Licence se člení na ty, které vycházejí př́mo z Konvence, a ty, které zavádí sama FAČR. Pro jednotlivé úrovně soutěží je předepisován požadavek na konkrétní druh trenérské licence opravňující osobu funkci trenéra na takové úrovni zastávat, přičemž pro nejvyšši soutěž v kategorii mužů je striktně trváno na licenci typu UEFA PRO, jež vychází z Konvence (pro trenéry brankářů je však pro tuto soutěž předepisována licence „Trenér brankářů A“ založená na licencích FAČR). Pro každý typ licence je stanovován jiný rozsah vzdělávacích kurzů, v př́ípadě uchazečů, kteří splňují kritéria určitého počtu odehraných zápasů za národní reprezentační tým a/nebo v nejvyšších soutěžích jednotlivých členských asociací FIFA je možno získat některé typy licencí i ve zrychleném režimu tzv. „fast track“.35

tion dostupná online na: $<$ https://www.uefa.com/MultimediaFiles/Download/uefaorg/CoachingCoachedu /02/29/42/76/2294276_DOWNLOAD.pdf> [cit. 31. 10. 2018].

32 Z druhé strany i UEFA zavazuje své členské národní asociace respektovat její předpisy - srov. čl. 7 Stanov UEFA. Dostupné online na: <https://www.uefa.com/MultimediaFiles/Download/uefaorg/General /02/54/12/62/2541262_DOWNLOAD.pdf>_[cit. 31. 10. 2018].

33 Čl. 1 odst. 2 Řádu.

34 Eventuálně dle čl. 4 odst. 5 Stanov FAČR také soutěžích organizovaných na základě smlouvy s FAČR prostřednictvím Ligové fotbalové asociace, z. s.

35 Srov. např. pro licenci UEFA PRO předpokládaný rozsah 543 hodin strukturovaný do mnoha tematických bloků obsahujících teorii, praxi i stáže. Osvojení si znalostí a dovedností je předmětem zkoušek. Viz Př́íloha č. 5 Řádu. 
Systém licencí je navzájem podmíněn tak, že pro absolvování kurzu licence určitého stupně se zpravidla předepisuje, že uchazeč musí být držitelem licence bezprostředně předcházející nižší úrovně. Licence založené na Konvenci jsou považovány za navzájem uznatelné, at' je vydala jakákoliv z členských asociací UEFA, takže na tomto základě může v české nejvyšší fotbalové soutěži působit např. italský fotbalový trenér, aniž by musel licenci získat v České republice. Licence vyšších úrovní jsou ve své platnosti zpravidla časově omezeny, ̌̌ád proto nastavuje pravidla tzv. doškolování trenérů, jež musí každý držitel takto omezené licence absolvovat, aby si svou licenci udržel. Trenérské kurzy jsou ze strany FAČR akreditovány u Ministerstva školství a jejich absolvent při splnění předepsaných povinností obdrží od FAČR jednak „diplom“ a jednak trenérský průkaz a pro nejvyšší soutěže i visací kartu, kterou se může v rámci soutěžních utkání prokazovat.

V celkovém kontextu spolkové regulace (demonstrované na př́íkladu FAČR) je možno tedy uzavřít, že pro výkon trenérství v rámci regulovaných sportovních/soutěžních odvětví je rámec právního vztahu trenéra ke sportovnímu klubu, popř. k zastř̌šující sportovní asociaci značně rozšířen právě o tyto spolkové povinnosti. Nejen pro trenéry tak platí, že nestačí, aby uzavřeli svou soukromoprávní smlouvu s klubem jakožto druhou smluvní stranou, nýbrž musí plnit i povinnosti ukládané sportovní asociací. $\mathrm{V}$ prrípadě, že by trenér např. nedisponoval pro určitou kategorii soutěží př́slušnou licencí či nebyl přes výslovný požadavek sportovní asociace jejím registrovaným členem, jeho smlouva by de facto ve vztahu ke sportovnímu prostředí byla neúčinná. Ačkoliv by tak mohl vzniknout na první pohled platný soukromoprávní závazek mezi klubem a „trenérem“, takováto fyzická osoba by nemohla vystupovat na oficiálních pozicích při žádném oficiálním utkání hraném podle soutěžních pravidel dané asociace. Pokud by byla tato pravidla porušena, mohl by naopak být trenér ${ }^{36} \mathrm{a} /$ nebo klub ze strany ř́dící sportovní asociace sankcionován na základě disciplinárního či obdobného řádu. ${ }^{37}$ Dalším možným důsledkem vnitrospolkové neúčinnosti takové smlouvy by mohlo za některých okolností být i to, že by plnění z ní nebylo možno vynucovat $\mathrm{v}$ rámci interních kvazi-arbitrážních orgánů, které jinak za účelem zachování smluvní stability v rámci sportovních vztahů sportovní asociace obvykle zřizují. ${ }^{38}$

Jinou otázkou, $\mathrm{v}$ právní teorii i praxi zatím neřešenou, je $\mathrm{v}$ takovém případě vynutitelnost plnění z takové smlouvy před obecnými soudy. ${ }^{39} \mathrm{Tj}$. zda by se soudy striktně držely ustanovení smlouvy, která by nebyla v rozporu s obecně platným právním řádem, či zda by šly nad tento rámec a byly ochotny přihlédnout i k jejímu širšímu kontextu, kterým je celá regulace výkonu trenérské činnosti v předpisech sportovních asociací. Domnívám se, že s ohledem na posouzení institutů a principů namítaných př́ípadně v tomto hypotetickém právním sporu jednou ze stran, by se soud musel (i pokud by daná

36 Za předpokladu, že by byl členem sportovní asociace.

37 Srov. např. § 50 Disciplinárního řádu FAČR. Dostupné online na: $<$ https://facr.fotbal.cz/uredni-deska-predpisy/221?category $=1>$ [cit. 31. 10. 2018].

38 Srov. poznámka pod čarou č. 23.

$39 \mathrm{Tj}$. např. byla-li by uzavřena takováto trenérská smlouva podle $\S 1746$ odst. $2 \mathrm{OZ}$, avšak nebyly by splněny podmínky pro její „účinnost ve sportovním prostředí", např. pokud by se trenér nemohl aktivně zapojovat do soutěží organizovaných sportovní asociací. Sportovní klub by na základě této skutečnosti hypoteticky přstal trenérovi vyplácet smluvně sjednané odměny. 
smlouva neobsahovala př́mý „,inkorporační“ odkaz na spolková pravidla) tímto širším rámcem meritorně zabývat, a to např. s ohledem na otázky uzavření smlouvy v dobré viře a zákazu prospěchu z vlastní nepoctivosti (§ $6 \mathrm{OZ}$ ), či nemožnosti splnění smlouvy od jejího počátku jakožto důvodu neplatnosti smlouvy ( $\$ 579$ a $580 \mathrm{OZ}$ ).

Při uzavírání trenérských smluv je proto praktické, aby smluvní strany do smlouvy zahrnuly výslovné ustanovení, že trenér je povinen disponovat (nejpozději k určitému datu) trenérskou licencí př́slušné kategorie. $V$ príípadě nesplnění tohoto závazku si může klub ve smlouvě utvrdit, že se z jeho pohledu jedná o takový nedostatek, který jej opravňuje od smlouvy odstoupit podle § 2001 a násl. OZ. To je myslitelné za předpokladu, že většina trenérských smluv je v České republice uzavírána v podobě inominátních smluv podle $\mathrm{OZ}$ a nikoliv jako smlouvy pracovní. ${ }^{40}$

Na rozdíl od profesionálních hrášských smluv nemá FAČR nikde daný povinný obsah smlouvy pro trenéry. ${ }^{41} \mathrm{Z}$ hlediska smluvních vztahů mezi klubem a trenérem tak neexistuje jednotné vodítko toho, jaká ustanovení by měla smlouva obsahovat a na smluvní strany jsou proto kladeny vyšší nároky při sjednávání smlouvy, za jejíž obsah nepřebírá $\mathrm{v}$ tomto př́padě FAČR žádnou odpovědnost. Na rozdíl od profesionálních hráčských smluv nejsou trenérské smlouvy u FAČR ani předmětem registrace, registrují se v evidenci členů FAČR pouze trenérské licence spolu se základními údaji o jejich držitelích. ${ }^{42}$

\section{SHRNUTÍ}

Jak již bylo znát z exkurzu do úpravy trenérské profese na Slovensku, nelze popis české situace předložený $\mathrm{v}$ tomto textu zevšeobecňovat i pro situaci v zahraničí. V prŕípadě angažování trenérů s mezinárodní prestiží se může stát, že „slabší smluvní stranou" nebude v takovém př́ípadě trenér, nýbrž fakticky klub. Traduje se, že když byl do české nejvyšší fotbalové ligy dojednáván př́íchod zahraničního trenéra ze západní Evropy, nebyl to klub, kdo předložil návrh smlouvy, ale právě trenér sám, který

$40 \mathrm{~V}$ př́ípadě výkonu trenérské činnosti v režimu pracovněprávních vztahů by nešlo v takovémto případě ukončit pracovní poměr s okamžitým účinkem, a to proto, že absence příslušné licence není v př́ipadě trenéra porušením právních předpisů nýbrž „pouze“ interních norem spolku (srov. § 55 odst. 1 písm. b) $\mathrm{ZP)}$. Z hlediska výpovědi zaměstnanému trenérovi by pak přicházela v úvahu pouze aplikace $\S 52$ písm. f) $\mathrm{ZP}$, „nesplňuje-li [trenér] bez zaviněni zamèstnavatele požadavky pro rádný výkon této práce.“ $\mathrm{V}$ př́padě dohod o pracích konaných mimo pracovní poměr by pak přicházelo $\mathrm{v}$ úvahu zrušení cestou výpovědi ze strany klubu podle $§ 77$ odst. 4 písm. b) ZP.

41 K povinným náležitostem hráčské profesionální smlouvy FAČR srov. čl. 18-22 Přestupního řádu FAČR; dostupné online na https://facr.fotbal.cz/uredni-deska-predpisy/216?category=1 [cit. 31. 10. 2018]. I tato úprava čerpá z evropského fotbalového prostředí, když implementuje požadavky plynoucí z Autonomní dohody o minimálních požadavcích na standardní hráčské smlouvy (Autonomous Agreement on Minimum Requirements for Stadard Player Contracts) ze dne 19. 4. 2012. Dostupné online na: $<$ https://fifpro.org/attachments/article/5292/Autonomous\%20Agreement\%20on\%20Minimum\%20 Requirements\%20for\%20Standard\%20Player\%20Contracts.pdf> [cit. 31. 10. 2018]. Ta vznikla na základě evropského sociálního dialogu ve smyslu čl. 155 SFEU, během nějž se na pravidlech vtělených do této dohody společně usnesly zástupci UEFA, EPFL (European Professional Football Leagues), FIFPro Division Europe (evropská pobočka organizace zaštit'ující fotbalové hráče - Fédération Internationale des Associations de Footballeurs Professionnels) a ECA (European Club Association).

42 Srov. $§ 6$ a $§ 29-31$ Evidenčního a registračního řádu FAČR. 
základní pracovní verzi smlouvy přichystal a předložil ji k dalšímu jednání. V takových př́padech může být i zcela vyloučena aplikace právního řádu České republiky, jelikož se (nikoliv pracovněprávní) smlouva rrídí právem jiného státu. Na druhou stranu při působení v soutěži organizované pod hlavičkou FAČR (či Ligové fotbalové asociace) ani toto nebude na překážku plné aplikovatelnosti českých spolkových předpisů na pozici trenéra. Trenér tak musí být napřs. pro nejvyšší fotbalovou ligu v držení předepisované licence UEFA PRO, jíž mohl ale získat u jiné členské asociace UEFA, a plnit $\mathrm{k}$ tomu další povinnosti plynoucí z regulí FAČR, UEFA či FIFA. Spolková regulace je tudíž pro sportovní trenéry mnohdy zcela klíčovou otázkou, at’ již je jejich právní vztah s klubem založen na jakémkoliv smluvním typu.

Do budoucna lze i v České republice očekávat posun k širší regulaci sportu tak, jak se tomu děje v řadě okolních evropských států. Lze se proto domnívat, že legislativní pozornosti nakonec neunikne ani otázka právní úpravy smluv sportovců a dalších osob na sportu se podílejících, tedy i trenérů. Pravděpodobně tak dřive či později u nás projde proměnou i současný systém výkonu trenérské činnosti z pohledu práva.

JUDr. David Kohout, Ph.D.

Právnická fakulta Univerzity Karlovy

kohout@prf.cuni.cz 


\title{
VYJADRENIE ZÁVISLEJ PRÁCE V POISŤOVACOM SYSTÉME SR
}

\author{
MILOŠ LACKO*
}

\begin{abstract}
Expression of dependent work in Insurance System of the Slovak Republic
The current period is characterized by an increase in the performance of dependent work its new forms supported by the information technology. These new forms, due to guaranteeing the social protection, require a change of approach both in the area of labour law and in the field of social protection systems based on the insurance policy. The Slovak legislator undertook extensive changes in the insurance system between the years of 2011 and 2013, linking the definition of the insurance category of employee to the tax classification of income from the employment. The contribution focuses on and evaluates the impact of this change on the expanding group of protected persons exercising employment in selected types of legal relationships, and in particular for persons carrying out activities on the basis of agreements on work performed outside the employment relationship, including status exceptions (i.e. beneficiaries of basic pension benefits and pupils / students performing temporary occasional or seasonal work) and managers (and associates) of limited liability companies. The contribution also shows the lack of readiness and systemic consistency of the legislation regulating the coexistence of the employment and the entitlement to the payment of certain benefits from the social insurance system (maternity benefit and early old-age pension).
\end{abstract}

Keywords: the insurance category of employee; insurance dimension of the agreements to work outside the scope of employment relationship; levy participation of managers (and associates) of limited liability companies; the impact of dependent work performance on the payment of certain benefits from the social insurance system

Kl’účové slová: poistná kategória zamestnanca; poistný rozmer dohôd o prácach vykonávaných mimo pracovného pomeru; odvodová participácia konatel’ov (aj spoločníkov) spoločností s ručením obmedzením; vplyv výkonu závislej práce na výplatu niektorých dávok sociálneho poistenia

DOI: $10.14712 / 23366478.2019 .4$

\footnotetext{
* Autor je tajomníkom a členom katedry pracovného práva a práva sociálneho zabezpečenia na Právnickej fakulte Trnavské univerzity v Trnave. Príspevok spracoval s finančnou podporou projektu Agentúry na podporu výskumu a vývoja č. APVV-15-0066 pod názvom „Nové technológie v pracovnom práve a ochrana zamestnanca“. Zodpovedná riešitel'ka prof. JUDr. Helena Barancová, DrSc., PF Trnavskej univerzity v Trnave.
} 


\section{ÚVOD}

Systémy sociálnej ochrany (možno použit' aj označenie sociálnej bezpečnosti), ktoré pre svoju existenciu a plnenie stanovených sociálnych úloh vyžadujú aktívnu participáciu, sú v dôsledku tohto systémového (výstavbového) prvku spravidla vybudované na aktívnej príspevkovej (odvodovej) participácii osôb (účastníkov systému), ktorú odvodzujú od príjmov plynúcich z výkonu zárobkovej činnosti realizovanej v predvídaných formách. Základnými formami výkonu zárobkovej činnosti v príspevkových systémoch sociálnej ochrany sú výkon závislej činnosti a výkon samostatnej zárobkovej činnosti.

Následne výkon závislej práce je uskutočňovaný vo viacerých variáciách pod jednotiacim základom pojmového vymedzenia „klasického“ zamestnanca vykonávajúceho závislú prácu, pričom podla pracovnoprávnej teórie nespochybnitel'nými prvkami pojmu zamestnanec sú osobný výkon práce a subordinačný princíp ${ }^{1}$. Tieto pojmové znaky zamestnanca sú $v$ podstatnej miere determinované práve charakterom vykonávanej (závislej) práce. Podla § 1 Zákonníka práce závislou prácou, ,je práca vykonávaná vo vztahu nadriadenosti zamestnávatel'a a podriadenosti zamestnanca, osobne zamestnancom pre zamestnávatel'a, podl'a pokynov zamestnávatel'a, v jeho mene, v pracovnom čase určenom zamestnávatel'om“. V nasledujúcom odseku uvedeného ustanovenia Zákonníka práce je vyjadrený zákaz výkonu závislej práce v zmluvnom občianskoprávnom vzt’ahu alebo v zmluvnom obchodnoprávnom vzt’ahu.

Je len preferenčnou vol'bou zákonodarcu zohl'adňujúcou a rešpektujúcou ochrannú funkciu sociálneho zabezpečenia, ktorým skupinám zamestnancov definovaných selektívnymi znakmi poskytne a zaručí určitý stupeň hmotného zabezpečenia (resp. sociálnej ochrany), a to jednak čo do rozsahu krytých sociálnych udalostí a jednak čo do úrovne poskytovaného hmotného zabezpečenia kvantifikovaného prizmou hodnôt sociálnej potrebnosti a adekvátnosti (resp. primeranosti). V poslednom období je podstata zaužívaných schém a prístup $\mathrm{k}$ tvorbe úrovne poskytovaného hmotného zabezpečenia fyzických osôb vykonávajúcich závislú prácu v pracovnom pomere a obdobnom pracovnom vzt’ahu ohrozovaná jednak únikom do oblasti výkonu podnikatel'skej činnosti prostredníctvom obchodných spoločností a jednak vznikom nových digitálnych platforiem výkonu zárobkovej činnosti oslabujúcich subordinačný princíp výkonu závislej práce (napr. tzv. „uberizácia“²).

1 K analýze pojmových znakov zamestnanca a $\mathrm{k}$ novodobým špecifikám výkonu závislej práce pozri BARANCOVÁ, H. Teoretické problémy pracovného práva. Plzeň: Aleš Čeněk, 2013. s. 74-83. ISBN 978-80-7380-465-7.

2 K postaveniu vodiča služby Uber ako kvázi zamestnanca v modeloch kolaboratívnej ekonomiky pozri BARANCOVÁ, H. Zamestnanec, štatutár a spoločník v pracovnom práve. Praha: Leges, 2018. s. 75 a nasl. ISBN 978-80-7502-300-1.

K argumentácí založenej na skutkových okolnostiach prejedávaných sporov, či vodič Uberu je kvázi zamestnancom alebo nezávislým podnikatel’om pozri KRIŽAN, V. Uber v rozhodovacej činnosti orgánov práva. In: BARANCOVÁ, H. - OLŠOVSKÁ, A. (eds.). Pracovné právo v digitálnej dobe. Praha: Leges, 2017, s. 121-124. ISBN 978-80-7502-259-2. 
Uvedené v konečnom dôsledku destabilizujúco pôsobí na finančnú udržatel'nost' príspevkových systémov sociálnej ochrany, ak sú vybudované na samofinancovaní (t. j. odpojení od iných rozpočtových sústav) a osobitne počas obdobia ekonomickej recesie.

Slovenský zákonodarca vykonal v právnej úprave poist'ovacieho systému SR (pozostáva zo systému sociálneho poistenia a systému verejného zdravotného poistenia) niekol'ko krokov, ktorými čiastočne reaguje na výkon závislej práce, čím predovšetkým sleduje zaistenie finančnej udržatel'nosti poistných systémov vytvárajúcich poist'ovací systém $\mathrm{SR}^{3}$. V nasledujúcich častiach príspevku priblížime uvedené kroky slovenského zákonodarcu a poukážeme na niektoré zjavné kontroverzie vyvolané jeho legislatívnymi krokmi, ktoré súčasne znižujú (resp. ohrozujú) úroveň sociálnej ochrany.

\section{ZMENA VO VYMEDZENÍ POISTNEJ KATEGÓRIE ZAMESTNANCA}

V právnej úprave poistných systémov Slovenskej republiky 4 do 31 . decembra 2010 dominoval enumeratívny prístup vo vymedzení skupín fyzických osôb vykonávajúcich závislú prácu v pracovnom pomere alebo obdobnom pracovnoprávnom vzt'ahu (dodávame, že obdobný prístup sa uplatňoval aj u poistnej kategórie samostatne zárobkovo činnej osoby 5 ). Podl'a ustanovenia 33 zákona č. 461/2003 Z. z. o sociálnom poistení účinného do 31 . decembra 2010 sa zárobkovou činnostou na účely nemocenského poistenia, dôchodkového poistenia a poistenia v nezamestnanosti rozumela primárne činnost' zamestnanca $\mathrm{v}$ pracovnom pomere, pričom na jeho roveň boli postavené fyzické osoby v štátnozamestnaneckom pomere, v služobnom pomere, v pracovnom vzt'ahu k družstvu, v postavení ústavného činitel’a, verejného ochrancu práv, v postavení predsedu vyššieho územného celku, poslanca vyššieho územného celku, starostu a primátora, riaditel’a štátneho podniku a napokon osôb vo výkone trestu odňatia alebo vo výkone väzby, ak boli zaradené na výkon prospešných prác (mimo ústavu).

Na účely zdravotného poistenia sa do 31 . decembra 2010 považovala za zamestnanca, okrem už uvedených skupín fyzických osôb v systéme sociálneho poistenia, aj fyzická osoba $\mathrm{v}$ postavení:

- konatel'a spoločnosti s ručením obmedzeným, ak za túto prácu dostával odmenu považovanú za príjem zo závislej činnosti podl’a zákona č. 595/2003 Z. z. o dani z príjmov,

- člena štatutárneho orgánu, člena správnej rady, člena dozornej rady, člena kontrolnej komisie a člena iného samosprávneho orgánu právnickej osoby, ak za výkon

3 Poznamenávame, že systém sociálneho poistenia pozostáva z nemocenského poistenia, dôchodkového poistenia, poistenia $\mathrm{v}$ nezamestnanosti a úrazového poistenia a garančného poistenia, pričom posledne dva uvedené poistné systémy sú poistením zamestnávatel'a.

4 Poist'ovací systém SR pozostáva z dvoch samostatných poistných systémov, a to systému sociálneho poistenia upraveného zákonom č. 461/2003 Z. z. a systému verejného zdravotného poistenia upraveného zákonom č. 580/2004 Z. z.

5 Pre komplexnost’ informácie uvádzame, že tret’ou poistnou kategóriou v systéme sociálneho poistenia je dobrovol'ne poistená osoba a v systéme verejného zdravotného poistenia je to okrem zamestnanca a samostatne zárobkovo činnej osoby samoplatitel’ poistného (definovaný v § 11 ods. 2 zákona č. 580/2004 Z. z.) 
funkcie dostával odmenu považovanú za príjem zo závislej činnosti podl’a zákona č. 595/2003 Z. z.,

- spoločníka spoločnosti s ručením obmedzeným, komanditistu komanditnej spoločnosti, ak boli odmeňovaní za prácu $\mathrm{v}$ spoločnosti formou, ktorá sa podla zákona č. 595/2003 Z. z. považovala za príjem zo závislej činnosti.

Uvedené nazeranie na poistnú kategóriu zamestnanca zákonodarca zásadne extenzívne redefinoval previazaním na daňovú klasifikáciu príjmov zo závislej činnosti (zákonom č. 543/2010 Z. z. meniacim zákon sociálnom poistení a zákonom č. 499/2010 Z. z. meniacim zákon o zdravotnom poistení s účinnostou od januára 2011), ked’že právna úprava daňovo klasifikovaných príjmov zo závislej činnosti je v zásade založená na subordinačnom znaku pracovnoprávneho vzt’ahu ,dodržiavania alebo plnenia príkazov/ pokynov ukladaných platitel'om príjmu alebo inou osobou" identifikovaného v širšom spektre právnych vzt’ahov, a v prípade niektorých právnych vzt'ahov ale značne oslabeného, čo je len dôsledkom charakteru a účelu daného právneho vzt’ahu z ktorého plynie daňovníkovi príjem a ktorý zákonodarca cielene hodnotí ako príjem zo závislej činnosti. Takým príkladom sú platy a funkčné príplatky ústavných činitel'ov Slovenskej republiky, verejného ochrancu práv, poslancov Európskeho parlamentu zvolených na území SR, ktorí vykonávajú svoj mandát osobne podl’a svojho svedomia a presvedčenia a nie sú viazaní príkazmi (čl. 73 ods. 2 Ústavy SR) a v prípade verejnej funkcie nestranne a dodržiavajúc a uplatňujúc právny poriadok SR a osobitne chrániac verejný záujem a základné ludské práva a slobody.

Zárobkovou činnost’ou sa na účely sociálneho poistenia a (verejného) zdravotného poistenia rozumie príjem, ktorý je podla zákona č. 595/2003 Z. z. klasifikovaný ako zdanitel'ný príjem zo závislej činnosti ${ }^{6}$ okrem nepeňažného príjmu z predchádzajúceho právneho vzt’ahu, ktorý zakladal právo na príjem zo závislej činnosti poskytnutého z prostriedkov sociálneho fondu. Ďalej sa zárobkovou činnost'ou (zamestnanca) rozumie aj činnost', z ktorej príjem nepodlieha dani z príjmov v dôsledku dodržania zákazu dvojitého zdanenia. Napokon zárobkovou činnost’ou je činnost' fyzickej osoby, z ktorej príjem zo závislej činnosti nepodlieha dani z príjmov, ale na túto fyzickú osobu sa

6 Najvýznamnejšími zdanitel’nými príjmami zo závislej činnosti sú:

a) príjmy zo súčasného alebo z predchádzajúceho pracovnoprávneho vzt'ahu, služobného pomeru, štátnozamestnaneckého pomeru alebo členského pomeru, alebo z obdobného vzt’ahu, v ktorom je daňovník povinný dodržiavat' pokyny alebo príkazy platitel’a príjmu,

b) príjmy za prácu likvidátorov, prokuristov, nútených správcov, členov družstiev, spoločníkov a konatelov spoločností s r. o. a komanditistov k. s., a to aj ked’ nie sú povinní pri výkone práce pre družstvo alebo pre spoločnost' dodržiavat' príkazy inej osoby,

c) platy a funkčné príplatky ústavných činitel’ov, verejného ochrancu práv, poslancov EP, prokurátorov a vedúcich ostatných ústredných orgánov štátnej správy SR,

d) odmeny za výkon funkcie $\mathrm{v}$ štátnych orgánoch, $\mathrm{v}$ orgánoch územnej samosprávy a $\mathrm{v}$ orgánoch iných právnických osôb alebo spoločenstiev,

e) odmeny obvinených vo väzbe a odmeny odsúdených,

f) príjmy z prostriedkov sociálneho fondu,

g) príjmy plynúce v súvislosti s minulým, súčasným alebo budúcim výkonom závislej činnosti alebo funkcie bez ohl'adu na to, či daňovník pre platitel’a príjmu skutočne vykonával, vykonáva alebo bude vykonávat' túto závislú činnost' alebo funkciu,

h) príjmy z činnosti športovca na základe zmluvy o profesionálnom vykonávaní športu a príjmy z činnosti športového odborníka na základe zmluvy o výkone činnosti športového odborníka (od roku 2019). 
uplatňujú sociálnozabezpečovacie právne vzt’ahy SR podl’a koordinačných pravidiel obsiahnutých v nariadení Európskeho parlamentu a Rady (ES) č. 883/2004 z 29. apríla 2004 o koordinácii systémov sociálneho zabezpečenia ${ }^{7}$ alebo podl’a medzinárodnej zmluvy, ktorá má prednost' pred zákonmi SR. Naopak zárobkovou činnost’ou nie je činnost' vykonávaná v právnom vzt’ahu, z ktorej plynúce príjmy nie sú predmetom dane alebo sú od dane oslobodené.

Zárobkovou činnost'ou na účely systému zdravotného poistenia nie je ani činnost', na základe ktorej plynú príjmy, z ktorých sa daň vyberá zrážkou, a ani príjem, ktorý predstavuje odchodné, výsluhový príspevok alebo je rekreačnou starostlivost'ou poskytovanou zo systému sociálneho zabezpečenia policajtov a vojakov podla zákona č. 328/2002 Z. z. o sociálnom zabezpečení policajtov a vojakov. Dodávame, že na účely platenia poistného na verejné zdravotné poistenie zákonodarca zahrnul do vymeriavacieho základu na platenie poistného (aplikujúceho sa na účely ročného zúčtovania preddavkov na poistné na zdravotné poistenie) aj daňovo klasifikované príjmy z kapitálového majetku a tzv. ostatné príjmy ${ }^{8}$.

Daňovo-právny prístup ku kvalifikácii určitej činnosti ako výkonu závislej práce možno stručne uviest' na pozadí rozhodovacej činnosti Najvyššieho súdu $\mathrm{SR}^{9}$, podl'a ktorého klúčovým kritériom je posúdenie prejavu vôle („byt'“ zamestnancom alebo podnikatel'om), t. j. rozdiel nie je identifikovatel'ný v obsahu právneho úkonu (resp. právneho vzt’ahu ${ }^{10}$ ale v subjekte, ktorý prejavuje vôl'u smerujúcu k uzatvoreniu určitého právneho úkonu. Takto nastavený judikatórny prístup ale nedáva odpoved’ na riešenie problematiky zastretých pracovnoprávnych vzt’ahov nepomenovanými zmluvami označovaných aj ako tzv. „Švarc systém“ čo má v konečnom dôsledku nepriaznivé dôsledky na samotné zdrojové financovanie príspevkových (poistných) systémov sociálnej ochrany.

V porovnaní s právnym stavom účinným do 31 . decembra 2010 sa značne rozšírilo definičné vymedzenie poistnej kategórie zamestnanca, ktorým je fyzická osoba vykonávajúca zárobkovú činnost’ v právnom vzt’ahu, ktorý jej zakladá právo na „zdanitel'ný“ príjem zo závislej činnosti (prvý definičný znak), pričom tento príjem môže byt' $\mathrm{v}$ rámci daného právneho vzt’ahu poskytovaný pravidelne mesačne alebo nepravidelne. Periodicita vzniku práva na poskytnutie príjmu zo závislej činnosti, ako druhý definičný

7 Ú. v. EÚ, L 284, dňa 30. 10. 2009.

8 Poznamenávame, že poistné na zdravotné poistenie sa platí aj z podielu na zisku (dividend), ak boli vyplatené fyzickej osobe podiel'ajúcej sa na základnom imaní obchodnej spoločnosti alebo družstva zo zisku z účtovného (resp. zdaňovacieho) obdobia 2011 až 2016. Od roku 2017 je dividenda zdaňovaná 7 \% zrážkovou daňou. V rámci sociálneho poistenia platí poistné na nemocenské poistenie, dôchodkové poistenie a poistenie $\mathrm{v}$ nezamestnanosti zamestnanec aj podielu na zisku vyplateného obchodnou spoločnost'ou alebo družstvom, ak sa majetkovo nepodiel'a na ich základnom imaní.

9 Rozsudok NS SR sp. zn. 3 Sžf 80/2008 zo dňa 23. apríla 2009. Dostupné online na: <http://merit.slv .cz/3Szf80/2008>, navštívené dňa 29. októbra 2018.

10 Odporca $\mathrm{v}$ danej veci prekvalifikoval príjmy z podnikania na príjmy zo závislej činnosti s právnym poukazom na znenie $\S 2$ ods. 3 a 6 zákona č. 511/1992 Zb. (v súčasnosti § 3 a 6 zákon č. 563/2009 Z. z. o správe daní (daňový poriadok) a o zmene a doplnení niektorých zákonov), a to najmä že ,pri uplatňovaní daňových predpisov v daňovom konaní sa berie do úvahy vždy skutočný obsah právneho úkonu alebo inej skutočnosti rozhodujúcej pre určenie alebo vybratie dane.“ 
znak poistnej kategórie zamestnanca, má zásadný dopad na rozsah obligatórnej participácie v systéme sociálneho poistenia.

Do súčasného právneho znenia zaznamenala poistná kategória dve významné modifikácie, a to zákonom č. 252/2012 Z. z. a krátko na to zákonom č. 413/2012 Z. z., ktoré priniesli jej rozšírenie o fyzické osoby v právnom vzt’ahu na základe dohôd o prácach vykonávaných mimo pracovného pomeru s nižšie uvedenými viacerými výnimkami, pričom jej aktuálnu „expandovanú“ podobu finalizoval zákon č. 266/2017 Z. z. účinný od 1. júla $2018^{11}$.

Ak daný právny vzt’ah zakladá právo na pravidelný mesačný príjem zo závislej činnosti, tak je fyzická osoba v plnom rozsahu zapojená do podsystémov sociálneho poistenia, t. j. je povinne nemocensky, dôchodkovo poistená a poistená v nezamestnanosti. Teda rozsah sociálnej ochrany zamestnanca je štandardný a touto redefiníciou poistnej kategórie sa v dôsledku daňovej kvalifikácie právneho vztahu, v ktorom sa vykonáva závislá pracovná činnost' iba rozšíril na väčší rozsah právnych vzt’ahov (napr. o právne vzt'ahy, v ktorých sa uskutočňujú kompetencie likvidátorov, prokuristov, nútených správcov, členov družstiev, spoločníkov a konatel'ov spoločností s ručením obmedzeným). Osobitne sú od 1 . januára 2013 zahrnuté aj fyzické osoby vykonávajúce prácu v právnom vzt’ahu na základe jednej z dohôd o prácach vykonávaných mimo pracovného pomeru s nižšie uvedenými oslobodzovacími odvodovými výnimkami.

Ak vyššie naznačený právny vzt’ah zakladá právo na nepravidelný mesačný príjem zo závislej činnosti, tak je fyzická osoba povinne zapojená len a výlučne do jedného podsystému sociálneho poistenia, a to dôchodkového poistenia. Dokonca ak splní statusovú podmienku, ktorá je spravidla spojená s podmienkou príjmového testu, tak je vylúčená aj z účasti na dôchodkovom poistení.

Bez ohl'adu na pravidelnost' príjmu zo závislej činnosti dosahovaného na základe dohody o pracovnej činnosti alebo dohody o vykonaní práce sú výlučne povinne dôchodkovo poistené fyzické osoby v postavení poberatel'a:

1. starobného dôchodku,

2. predčasného starobného dôchodku,

3. invalidného dôchodku, resp. invalidného výsluhového dôchodku,

4. výsluhového dôchodku, ak dovŕšili dôchodkový vek a

súčasne, ak ich mesačný príjem $\mathrm{v}$ podobe odmeny alebo priemernej mesačnej odmeny $z$ danej dohody presiahne $200 €$. Ak táto odmena u týchto statusovo definovaných fyzických osôb (poberatel'ov dôchodkových dávok) nepresiahne $200 €$, tak sú úplne vylúčení z účasti na podsystémoch sociálneho poistenia. Podotýkame, že uvedené príjmové vylúčenie sa vzt’ahuje len na jednu dohodárom (zamestnancom) určenú dohodu o prácach vykonávaných mimo pracovného pomeru (§ 227a ZoSP) a pre statusovú skupinu poberatel'a predčasného starobného dôchodku ${ }^{12}$ bolo zavedené zákonom č. 266/2017 Z. z. účinným od júla 2018.

11 Bližšie pozri: https://www.socpoist.sk/dohodari-a-postup-voci-sp-od-1-jula-2018/66096s, navštívené dňa 8. októbra 2018.

12 Poberatel' predčasného starobného dôchodku do uvedeného dátumu nemohol vykonávat' zárobkovú činnost' (zakladajúcu povinné dôchodkov poistenie) bez právneho následku zániku nároku na výplatu tohto dôchodku. Toto pravidlo sa ale už neaplikuje na situáciu ak tento poberatel' dôchodku dovíši dôchodkový 
Oproti uvedeným statusovým skupinám status študenta dennej formy vysokoškolského štúdia a žiaka strednej školy vykonávajúceho zárobkovú činnost' na základe dohody o brigádnickej práci študenta bol zavedený od začiatku tejto osobitnej právnej úpravy, t. j. od roku 2013. Táto právna úprava bola iba raz zásadne zmenená v prospech väčšieho vylúčenia týchto dvoch statusových podskupín z podsystému dôchodkového poistenia, a to zvýšením príjmovej hranice vylučujúcej vznik a existenciu povinného dôchodkového poistenia vrátane plnenia oznamovacej povinnosti zamestnávatel'a a riešenia situácie dodatočne vyplateného príjmu po skončení právneho vzt’ahu založeného dohodou o brigádnickej práci študenta (v súčasnosti to platí už na všetky dohody o prácach vykonávaných mimo pracovného pomeru).

Vzhl'adom na doteraz uvedené, bez ohl'adu na pravidelnost' príjmu zo závislej činnosti dosahovaného na základe dohody o brigádnickej práci študenta sú výlučne povinne dôchodkovo poistené fyzické osoby v postavení:

1. žiaka strednej školy do 18 . roku veku, ak (priemerný) mesačný príjem z tejto dohody (u jedného zamestnávatel'a) presiahne $200 €$ (predtým $66 €$ ),

2. študenta dennej formy vysokoškolského štúdia najdlhšie do 26 . roku veku' ${ }^{13}$, ak (priemerný) mesačný príjem z tejto dohody (u jedného zamestnávatel’a) presiahne $200 €($ predtým $155 €)$.

Uvedená príjmová hranica sa aplikuje aj na žiaka strednej školy a študenta vysokej školy pri praktickom vyučovaní v rámci odbornej (výrobnej) praxe, ktorý dosahuje $\mathrm{v}$ rámci tejto výučby a praxe (priemerný) mesačný príjem.

Ako bolo vyššie naznačené, tak vylúčenie (oslobodenie) z účasti na podsystémoch sociálneho poistenia sa vzt'ahuje len na jednu dohodárom (či poberatel'om vyššie uvedenej dôchodkovej dávky alebo žiakom / študentom) určenú dohodu, ak ich dohodár v danom mesiaci má uzatvorených viac a v tomto prípade bez ohl'adu na výšku príjmu, „dohodár“ prostredníctvom zakotveného práva vol’by (v § 227a zákona o sociálnom poistení) určí u svojho zamestnávatel’a čestným vyhlásením (vzor je zverejnený na portáli Sociálnej poistovne) iba jednu dohodu, na základe ktorej nebude mat' postavenie zamestnanca na účely dôchodkového poistenia ${ }^{14}$. Právne účinky uplatnenia tohto práva nastanú odo dňa vzniku právneho vzt’ahu založeného danou dohodou za predpokladu, že uplatnenie práva bolo zamestnávatel’ovi oznámené najneskôr $\mathrm{v}$ deň vzniku právneho vzt’ahu; inak od prvého dňa nasledujúceho kalendárneho mesiaca, v ktorom dohodár uskutočnil oznámenie zamestnávatel'ovi o uplatnení uvedeného práva. A právne účinky ukončenia uplatnenia práva dohodárom nastanú od prvého dňa nasledujúceho kalendárneho mesiaca, v ktorom bolo ukončenie uplatnenia práva oznámené zamestnávatel'ovi.

$\mathrm{V}$ prípade uvedených dvoch statusových kategórií dohodárov a ich práva na nepravidelnú odmenu (počas trvania danej dohody o prácach vykonávaných mimo pracovného pomeru) vo vzt’ahu k naplneniu podmienky príjmového testu oslobodzujúceho

vek. Od tohto okamihu zákonodarca zakotvuje žiadne pravidlo vylučujúce súbeh výkonu zárobkovej činnosti a poberania dôchodkovej dávky ( $\mathrm{v}$ tomto prípade starobného dôchodku).

13 Uvedené dve statusové požiadavky (vekové ohraničenie a forma vysokoškolského štúdia) na osobu v postavení zamestnanca na základe dohody o brigádnickej práci študentov zaviedla novela zákonníka práce s účinnost’ou od 1. januára 2013, t. j. zákon č. 252/2012 Z. z.

$14 \mathrm{~K}$ tomu bližšie pozri: <https://www.socpoist.sk/zamestnanec-dohodar/55424s\#03>, navštívené dňa 30. októbra 2018. 
ich z povinnej participácie na dôchodkovo poistení sa musí teória práva sociálneho zabezpečenia vysporiadat's novou materiálnou okolnost'ou, ktorá vyvolala požiadavku dodatočnej a spätnej registrácie už skončeného poistného vzt’ahu, ktorý v reálnom čase trvania danej dohody o prácach vykonávaných mimo pracovný pomer neexistoval. Tento právny stav odôvodňuje skutočnost', že v prípade dohodára s nepravidelným odmeňovaním $\mathrm{v}$ jednej $\mathrm{z}$ vyššie uvedených statusových pozícii nemožno pred a $\mathrm{v}$ čase trvania danej dohody porovnat výšku odmeny s príjmovou hranicou oslobodzujúcou od povinnej participácie na dôchodkovom poistení ${ }^{15}$.

Ďalej uvádzame osobitnú, i ked’ nie výnimočnú situáciu, ked’ dohodár má uzatvorenú jednu dohodu o prácach vykonávaných mimo pracovného pomeru s príjmom vy̌̌ším ako je vyššie uvedená $200 €$ hranica a uplatní si vol'bou práva vylúčenie z odvodovej povinnosti, tak mu vznikne povinné dôchodkové poistenie s povinnost'ou platit' poistné na dôchodkové poistenie ( $v$ členení na starobné poistenie $(4 \%)$ a invalidné poistenie $\left.(3 \%)^{16}\right)$ iba zo sumy prevyšujúcej vyššie uvedenú príjmovú hranicu, ktorá podla § 139c ods. 2 zákona o sociálnom poistení predstavuje rozdiel medzi mesačným príjmom (resp. priemerným mesačným príjmom) a zákonom ustanovenou „oslobodzovacou“ príjmovou hranicou. V prípade nepravidelne odmeňovaného dohodára (príp. aj jednorazovo odmeňovaného), ktorému by bol vyplatený príjem po skončení trvania dohody, sa poistné určí z „priemerného“ mesačného príjmu (ak presiahne vyššie uvedenú hranicu), ktorý je podl’a $\S 139$ b ods. 1 zákona o sociálnom poistení výsledkom „rozpočítania“ dodatočne vyplateného príjmu na jednotlivé mesiace trvania danej dohody o prácach vykonávaných mimo pracovného pomeru $\mathrm{v}$ danom kalendárnom roku.

K vol'be práva určit' prostredníctvom čestného vyhlásenia dohodu, na základe ktorej nebude mat'študent / poberatel' dôchodkovej dávky postavenie zamestnanca na účely dôchodkového poistenia uvádzame, že $\mathrm{v}$ aplikačnej praxi nastali viaceré situácie uplatnenia si vol'by práva súčasne u viacerých zamestnávatel'ov, ktorí nemali možnost' verifikovat' údaje uvedené $\mathrm{v}$ čestnom vyhlásení podanom študentom ${ }^{17}$ a ktorých po zistení tejto skutočnosti Sociálna poist’ovňa sankcionovala jednak za neprihlásenie študenta

15 Podl'a $§ 231$ ods. 1 písm. b) bodu č. 3 zákona o sociálnom poistení je zamestnávatel’ povinný prihlásit’ do príslušného registra zamestnanca v právnom vzt’ahu na základe ním určenej dohody, ktorý mu zakladá právo na nepravidelný príjem, na dôchodkové poistenie najneskôr do 8. dňa druhého mesiaca nasledujúceho po mesiaci, v ktorom právny vzt’ah zanikol alebo ak bol príjem vyplatený až po uplynutí tejto lehoty, tak do 8. dňa mesiaca nasledujúceho po mesiaci, v ktorom bol tento príjem vyplatený (súčasne je to aj deň splatnosti poistného) za predpokladu, že priemerný mesačný príjem z tejto dohody presiahol sumu $200 €$.

16 Percentuálne sadzby odvodovej povinnosti na dôchodkové poistenie zamestnávatel'a sú 14 \% na starobné poistenie, $3 \%$ na invalidné poistenie, $4,75 \%$ do rezervného fondu solidarity. Súčasne zamestnávatel' z titulu poistenca úrazového a garančného poistenia platí, ale pozor z celej sumy odmeny študenta, poistné na úrazové poistenie $0,8 \%$ a poistné na garančné poistenie $0,25 \%$. Z uvedeného vyplýva, že zamestnávatel' platí poistné na oba zmienené podsystémy sociálneho poistenie z titulu každej uzatvorenej dohody o prácach vykonávaných mimo pracovného pomeru.

17 Verifikácia údajov uvedených v čestnom vyhlásení je možná iba u nositel’a poistenia, ktorým je Sociálna poist'ovňa a ktorá je ako jediná zo zákona povinná vytvárat' a viest' registre späté s výkonom sociálneho poistenia (osobitne v danom prípade register poistencov a sporitel'ov starobného dôchodkového sporenia). $\mathrm{V}$ danom rozsudku súd záverom konštatuje ,... žalobca ako zamestnávatel nemá prístup do registra žalovaného, v ktorom sú evidované uplatnené výnimky v zmysle zákona o sociálnom poisteni a ani systém žalovaného pri prihlasovani zamestnancov zamestnávatel’mi neupozorní na duplicitné prihlásenie študenta, žalobca nemal inú možnost' ako sa spoliehat' na čestnost' pribratej účastníčky spočívajúcu v pravdivosti jej oznámenia a čestného vyhlásenia o neuplatňovaní si výnimky u iného zamestnávatel'a." 
ako zamestnanca na účely dôchodkového poistenia a jednak hrozilo sankcionovanie pre neplnenie odvodovej povinnosti na dôchodkové poistenie vrátane predpísania penále. Podl'a rozsudku Krajského súdu Bratislava sp. zn. 2S/150/2015 zo dňa 3. februára $2016^{18}$ striktná a formalistická a až mechanická aplikácia zákona o sociálnom poistení Sociálnou poist’ovňou (žalovanou) vedie k nespravodlivému výsledku a nerešpektuje princípy materiálneho právneho štátu (a ktorá vo výsledku zakladá prílišnú tvrdost' zákona voči adresátovi), čo znamená, že „Súdu prislúcha, aby sa zaoberal otázkou, či mechanická a formalistická aplikácia zákona bez ohl'adu na zmysel a účel záujmu chráneného právnou normou, nemôže priniest' absurdné následky a v prípade, že tomu tak je, aby takúto interpretáciu zákona odmietol a zvolil výklad v duchu zákona“. V závere rozsudku krajský súd uvádza, že „Jediným, kto porušil zákon o sociálnom poistení a nepostupoval v súlade s ním, bola pribratá účastnićka, ktorá uviedla žalobcu do omylu a zneužila inštitút odvodového zvýhodnenia, [...] Je neprípustné, aby negatívne dôsledky jej nečestného konania znášal žalobca, ktorému zákon na jednej strane neposkytuje žiadny prostriedok, prostredníctvom ktorého by mohol predist' vzniku takejto situácie, na druhej strane mu za neodvedenie poistného na sociálne poistenie hrozi penále aj napriek tomu, že konal v dobrej viere v pravdivost’ oznámenia a čestného vyhlásenia účastnícky."

D̆alej vo vzt’ahu k poistnej kategórii zamestnanca uvádzame, že zahŕňa vo svojom pojmovom vymedzení aj fyzickú osobu vykonávajúcu zárobkovú činnost' na základe dohôd o prácach vykonávaných mimo pracovného pomeru bez ohl'adu na vyššie uvedené podmienky, ale iba na účely systému úrazového poistenia a garančného poistenia, ktorého poistencom je zamestnávatel'. Uvedená subsumpcia pod poistnú kategóriu zamestnanca na účely úrazového a garančného poistenia je dôsledkom naplnenia princípu rovnosti a ochrannej funkcie sociálneho zabezpečenia, nakol'ko sa týmto definičným vymedzením priznáva a zabezpečuje rovnaký prístup $\mathrm{k}$ dávkam garančného a úrazového poistenia aj fyzickým osobám vykonávajúcim zárobkovú činnost' na základe dohôd o prácach vykonávaných mimo pracovného pomeru vrátane ich rodinných príslušníkov pre prípad smrtel'ného pracovného úrazu alebo choroby z povolania.

V systéme (verejného) zdravotného poistenia je v dôsledku zavedenia zúčtovacieho mechanizmu preddavkov na zdravotné poistenie situácia postavenia fyzických osôb vykonávajúcich činnost' na základe dohôd o prácach vykonávaných mimo pracovného pomeru jednoduchšia a prehl'adnejšia. Zákonodarca vyššie dve uvádzané statusové skupiny „dohodárov“ vylúčil z aktívnej (príspevkovej) participácie na verejnom zdravotnom poistení bez ohl'adu na výšku príjmu a počtu uzatvorených a realizovaných dohôd o prácach vykonávaných mimo pracovného pomeru. Podla § 11 ods. 3 v nadväznosti na $\S 10 \mathrm{~b}$ ods. 1 písm. a) zákona o zdravotnom poistení sa za zamestnanca nepovažuje fyzická osoba vykonávajúca zárobkovú činnost' v právnom vztahu, ktorý jej zakladá právo na príjem daňovo klasifikovaný ako príjem:

1. z dohôd o brigádnickej práci študentov (na rozdiel od systému sociálneho poistenia sa neaplikuje žiadna príjmová hranica),

2. z dohôd o vykonaní práce a dohôd o pracovnej činnosti dvoch relatívne samostatných skupín, a to poberatel'ov starobného dôchodku, predčasného starobného dô-

18 Rovnako aj v prípade rozsudku Krajského súdu Bratislava sp. zn. 6S/165/2015 zo dňa 5. októbra 2017. 
chodku alebo invalidného dôchodku a poberatel'ov výsluhového dôchodku (ak dovŕšili dôchodkový vek) alebo invalidného výsluhového dôchodku.

\subsection{ARGUMENTY V NEPROSPECH ODVODOVEJ PARTICIPÁCIE OSÔB VYKONÁVAJÚCICH ČINNOSŤ NA ZÁKLADE DOHODY O PRÁCACH VYKONÁVANÝCH MIMO PRACOVNÉHO POMERU}

Zavedenie obligatórnej participácie skupiny osôb vykonávajúcich činnost' na základe dohody o vykonaní práce a dohody o pracovnej činnosti s dojednaným pravidelným príjmom z tejto činnosti (s výnimkou poberatel’ov dôchodkových dávok) na nemocenskom poistení a poistení v nezamestnanosti je vzhl'adom na charakter krátkodobosti poskytovania dávok z týchto poistných systémov značne sporný až neúčelný vzhl'adom na ich pracovnoprávne vymedzenie (najmä náhodilost', krátkodobost' a výnimočnost' ich aplikovania zo strany zamestnávatel'a).

Neúčelnost' tohto prístupu identifikujeme jednak v medzinárodnoprávnom zakotvení nevyhnutnosti poskytnutia sociálnoprávnej ochrany pri vzniku nepriaznivých sociálnych udalostí, ktoré môžu nastat' u relevantných skupín ekonomicky činného obyvatel'stva $\mathrm{v}$ intenciách dohovorov Medzinárodnej organizácie práce a jednak vo funkcii dávky poskytovanej osobe vykonávajúcej činnost’ na základe dohody o vykonaní práce a dohody o pracovnej činnosti, štandardne $\mathrm{v}$ iných prípadoch kryje stratu príjmu každý jednotlivý deň trvania sociálnej udalosti, zatial' čo u uvedených osôb kryje stratu príjmu ako následku príslušnej udalosti iba po určité dni, resp. hodiny, počas ktorých by inak táto osoba vykonávala zárobkovú činnost'. Súčasne príležitostný a krátkodobý charakter výkonu zárobkovej činnosti na základe dohody o vykonaní práce a dohody o pracovnej činnosti st’ažuje fyzickým osobám splnenie požiadaviek obsiahnutých v dávkových schémach na priznanie príslušných dávok (ako je napr. materské, dávka $\mathrm{v}$ nezamestnanosti vo vzt’ahu $\mathrm{k}$ splneniu tzv. čakacej podmienky vyžadujúcej nemocenské poistenie $\mathrm{v}$ rozsahu min. 270 dní $\mathrm{v}$ posledných dvoch rokoch alebo dva roky poistenia v nezamestnanosti v posledných štyroch rokov), a to najmä ak fyzická osoba vykonáva sporadicky iba činnost’ na základe uvedených dohôd. V prípade zamestnancov vykonávajúcich prácu $\mathrm{v}$ pracovnom pomere, ktorí príležitostne vykonávajú činnost' na základe uvedených dohôd nenachádzame žiadny dôvod „,sociálno-ochranného“ charakteru, aby výkon činnosti na základe jednej z týchto dohôd zakladal povinnú participáciu na nemocenskom poistení, dôchodkovom poistení a poistení v nezamestnanosti. Ak fyzickej osobe vykonávajúcej zárobkovú činnost' na základe dohody o vykonaní práce alebo dohody o pracovnej činnosti s dojednaným pravidelným mesačným príjmom bude priznaná napríklad náhrada príjmu pri dočasnej pracovnej neschopnosti alebo nemocenská dávka, tak jej suma bude značne nízka ( $v$ dôsledku nizkych vymeriavacích základov na platenie poistného alebo aj $v$ dôsledku aplikovania pravdepodobného denného vymeriavacieho základu v situácii uvedenej $v \$ 57$ ods. 1 písm. b) zákona o sociálnom poistení alebo § 8 ods. 4 alebo § 8 ods. 6 zákona č. $462 / 2003$ Z. z. o náhrade príjmu pri dočasnej pracovnej neschopnosti) v porovnaní s dávkami rovnakého druhu priznanými zamestnancovi vykonávajúcom činnost' v pracovnom pomere na ustanovený týždenný pracovný čas pri jeho mesačnom odmeňovaní na úrovni minimálnej mesačnej mzdy 
(v roku 2018 je to $480 €$; v roku 2019 bude $520 €$ ) alebo minimálnej mzdy za odpracovanú hodinu (v roku 2018 je 2,759 €; v roku 2019 bude 2,989 €), nakol'ko dojednaný rozsah pracovnej činnosti na základe uvedených dohôd (aj po zohl'adnení minimálnej mzdovej požiadavky na odmeňovanie ,dohodára “ podl’a § 223 ods. 2 v nadväznosti na § 119 ods. 1 Zákonnika práce) je podstatne nižší najmä pri dohode o pracovnej činnosti v porovnaní so zamestnancom vykonávajúcom činnost' v pracovnom pomere.

Iný je však pohl'ad na situáciu skončenia dohody o vykonaní práce alebo dohody o pracovnej činnosti, ktorá fyzickej osobe zakladala povinnú participáciu na nemocenskom poistení v spojení s plynutím tzv. ochrannej lehoty v rozsahu 7 kalendárnych dní po skončení nemocenského poistenia na účely potenciálneho vzniku nároku na nemocenské dávky (nemocenské a ošetrovné). Takto naznačená situácia môže zakladat' zneužitie systému nemocenského poistenia a jeho dávkových vzt’ahov. Aj v dôsledku takéhoto potenciálneho scenára zákonodarca sprísnil podmienky na určenie obdobia ako rozhodujúceho obdobia na výmeru nemocenských dávok práve na strane poistnej kategórie zamestnanca. Je to najmä požiadavka nepretržitosti trvania poistného vzt'ahu na nemocenskom poistení a zaplatenia poistného v minimálnom rozsahu 90 dní pred vznikom sociálnej udalosti a pre prípad jej nesplnenia určenie nemocenskej dávky iba zo sumy odmeny poberanej z danej dohody o prácach vykonávaných mimo pracovného pomeru za predpokladu, ak je suma odmeny nižšia ako minimálny vymeriavací základ, z ktorého sa inak určuje suma nemocenskej dávky poskytovaná v porovnatel'nej situáci zamestnancovi v pracovnom pomere alebo obdobnom pracovnom vzt'ahu.

Pokial' ide o povinnú participáciu fyzickej osoby výlučne na dôchodkovom poistení, ktorá je postavení zamestnanca na základe pracovného pomeru a súčasne aj na základe jednej z dohôd o prácach vykonávaných mimo pracovného pomeru, tak jej opodstatnenost' nevylučujeme, nakol'ko takáto fyzická osoba si môže zvýšit' kvalitu budúcich dôchodkových práv. Uvedené by bolo možné aplikovat' aj vo vzt'ahu k výlučnému dôchodkovému poisteniu fyzických osôb vykonávajúcich činnost' na základe dohody o vykonaní práce a dohody o pracovnej činnosti za predpokladu, že tieto osoby dosahujú z týchto dohôd taký príjem, ktorý je v určitom predvídanom čase (v dôchodkovom systéme je to obdobie jedného roka, t. j. 365 dní poistenia) spôsobilý podporit' kvalitu budúceho nadobúdaného dôchodkového práva primeraného prostredníctvom získania kvalitatívne vyššieho „dôchodkového“ výpočtového parametra tzv. osobného mzdového bodu $(\mathrm{OMB})^{19}$. Práve z definičného vymedzenia OMB-u plynie opodstatnenost' obligatórnej participácie na dôchodkovom poistení u tých fyzických osôb, ktoré na základe dlhodobejšieho výkonu činnosti na základe dohody o vykonaní práce alebo dohody o pracovnej činnosti dosahujú v priemernom mesačnom vyjadrení príjem na úrovni priemernej mesačnej mzdy v hospodárstve SR, od ktorej sa nepriamo odvodzuje aj primeranost' hmotného zabezpečenia $v$ starobe a v aplikačnej rovine aj výmera základnej dôchodkovej dávky. Takým príjmom ale nie je príjem fyzickej osoby vykonávajúcej činnost' na základe dohody o vykonaní práce alebo dohody o pracovnej činnosti, a ani dohody o brigádnickej práci študentov, ktorý je nižší ako suma minimálneho vy-

19 Dopíňame, že osobný mzdový bod vyjadruje pomer medzi osobným vymeriavacím základom (t. j. ročným príjmom z ktorého platil poistenec poistné na dôchodkové poistenie) a sumou všeobecného vymeriavacieho základu (t. j. 12 - násobku priemernej mesačnej mzdy v hospodárstve SR) za príslušný kalendárny rok. 
meriavacieho základu zamestnanca v pracovnom pomere odmeňovaného na minimálnej úrovni (minimálnou mesačnou mzdou alebo minimálnou mzdou za odpracovanú hodi$n u)$ za rozhodujúce obdobie, ktorým je (predchádzajúci) kalendárny mesiac.

Nepravidelný príjem ,dohodára“ (vrátane statusových skupín poberatel’ov dôchodkových dávok a žiakov a študentov), ktorý nie je v rovnakom čase aj v pracovnom pomere, a ktorý je nižší ako suma minimálneho vymeriavacieho základu zamestnanca v pracovnom pomere nepredstavuje pre „dohodára“ fakticky žiadnu kvalitu v získavaní budúcich dôchodkových práv.

Na základe doteraz uvedeného sa natíska čiastkový hodnotiaci záver je zjavné, že zákonodarca pri snahe o čiastkové zapojenie fyzických osôb vykonávajúcich činnost' na základe dohôd o prácach vykonávaných mimo pracovného pomeru do systémov sociálnej ochrany okrem poistno-akumulačných snáh s ciel'om zaistenia ich finančnej udržatel’nosti bol nútený preniest' ich osobitný charakter ako atypických pracovnoprávnych vztahov aj do právnej úpravy predovšetkým systému sociálneho poistenia.

Z porovnania sociálnoprávneho postavenia fyzických osôb vykonávajúcich činnost' na základe dohôd o prácach vykonávaných mimo pracovného pomeru oproti skupine zamestnancov vykonávajúcich činnost' na základe pracovného pomeru vyvodzujeme záver, že fyzické osoby vykonávajúce činnost' na základe dohôd o prácach vykonávaných mimo pracovného pomeru predstavujú skupinu fyzických osôb (resp. poistencov) s nižšou úrovňou reálnej sociálnej ochrany, teda ide o skupinu poistencov, ktorí prevažne do systému sociálneho poistenia (osobitne dôchodkového poistenia) len odvádzajú poistné.

Z generálneho pohl'adu sme názoru, že fyzické osoby vykonávajúce činnost' na základe dohôd o prácach vykonávaných mimo pracovného pomeru majú podliehat' obligatórnej participácii na systémoch sociálnej ochrany (menovite na nemocenskom poistení, dôchodkovom poistení a verejnom zdravotnom poistení), ale za inak kvalitatívne nastavených podmienok, ktoré efektívne vyselektujú krátkodobo trvajúce neret’azené dohody o prácach vykonávaných mimo pracovného pomeru s dosahovaným príjmom, ktorý je z pohl'adu efektívnej sociálno-poistnej ochrany marginálny a až nepodstatný. Naznačené je možné dosiahnut' bud' prostredníctvom zavedenia mechanizmu ročného zúčtovania pri definovaní príjmovej hranice z titulu uskutočnených dohôd ${ }^{20}$, pri prekročení ktorej vznikne fyzickej osobe výlučne povinná participácia na dôchodkovom poistení alebo prostredníctvom kvalitatívnych požiadaviek spojených so vznikom povinnej participácie na nemocenskom poistení, dôchodkovom poistení a verejnom zdravotnom poistení (a to predovšetkým definovaním požiadavky vymedzujúcej pojem „ret’azenia“ dohôd, požiadavky na dobu trvania konkrétnej dohody a napokon výšky odmeny (resp. príjmu) plynúceho z konkrétnej dohody).

20 Dňa 23. októbra 2018 prijal slovenský zákonodarca zákon, ktorým sa s účinnost’ou od roku 2021 zavádza platenie preddavkov poistného na sociálne poistenie s ich následným ročným zúčtovaním v roku 2022. Schválené znenie zákona dostupné online na: <https://www.nrsr.sk/web/Default.aspx?sid=zakony /zakon\&MasterID=6832>, navštívené dňa 25. októbra 2018. 


\section{DÔSLEDKY VÝKONU ZÁVISLEJ PRÁCE NA VZNIK NÁROKU NA VÝPLATU DÁVKY}

Pojmové vymedzenie poistnej kategórie zamestnanca a jej previazanie na zdanitel’né príjmy zo závislej činnosti plynúce zo širokého spektra právnych vzt’ahov malo a má svoj dosah aj na poberatel'ov dôchodkových dávok vykonávajúcich zárobkovú činnost' po vzniku nároku na dôchodkovú dávku, a osobitne poberatel'ov predčasných starobných dôchodkov. Od roku 2011 zákonodarca pristúpil k zavedeniu pravidla o zániku nároku na výplatu predčasného starobného dôchodku jeho poberatel'ovi po obdobie, v ktorom vykonával zárobkovú činnost' zakladajúcu mu dôchodkové poistenie, čo od roku 2011 zakladala spravidla každá zárobková činnost' uskutočňovaná v legálnom právnom vzt’ahu, odhliadnuc od obchodnoprávnych vzt’ahov. Nezriedka sa vyskytujú situácie malých (až nepatrných) príjmov s dohodnutou nepravidelnost'ou ich vyplácania, ktoré spôsobujú zánik nároku na výplatu predčasného starobného dôchodku jeho poberatel’ovi, ktorý je iba v menšom rozsahu zárobkovo činný. Súčasne tento malý príjem nepostačuje takémuto dôchodcovi hradit' si životné potreby. Uvedené pravidlo bolo vo vzt'ahu $\mathrm{k}$ dosahovanému nepatrnému a nepravidelnému príjmu zo závislej činnosti a aj v kontexte ochrany pasívneho volebného práva (stažovatel'a, ktorý poberal odmenu za výkon poslanca v obecnom zastupitel'stve v sume 32,79€ za jedno zasadnutie zastupitel'stva určenú $v$ Zásadách odmeňovania poslancov) podrobené ústavnému prieskumu, pričom Ústavný súd SR nezistil arbitrárnost' a svojvôlu v odôvodnení rozsudku Najvyššieho sudu SR, ktorý by zasiahol do st’ažovatel'ovho základného práva na spravodlivý súdny proces, čím potvrdil rozsudok Najvyššieho súdu SR ${ }^{21}$. Najvyšší súd SR v danej veci (sp. zn. 10So/54/2013 zo dřa 28. mája 2014) konštatoval, že poslanec obecného zastupitel'stva s priznaným predčasným starobným dôchodkom poberajúci nepravidelnú odmenu za výkon tohto mandátu, i napriek jeho vyhláseniu o bezodplatnom výkone mandátu poslanca, sa považuje za zamestnanca s právom na nepravidelný príjem zo závislej činnosti, ktorý mu zakladá povinné dôchodkové poistenie po obdobie výkonu mandátu poslanca. Následne mu podl’a $§ 67$ ods. 4 a 5 zákona o sociálnom poistení po obdobie povinného dôchodkového poistenia zaniká nárok na výplatu predčasného starobného dôchodku. Obdobný skutkový stav bol prejedávaný na krajských súdoch, ale pre pochybnosti o existencii vyplácania odmien a následného vzniku povinného dôchodkového poistenia (žalobcu) súdy dané veci vrátili odporkyni (Sociálnej poist’ovni) na d’alšie konanie, v ktorom má úplne a presne zistit' skutočný stav veci²2.

Iným prípadom, ktorého spornost' vychádza z nejednoznačne legálne vyjadreného zámeru zákonodarcu, je súbeh výkonu zárobkovej činnosti (spravidla závislej činnosti) s právom na pravidelný mesačný príjem zakladajúci povinné nemocenské poistenie a nároku na výplatu materského.

Aktuálny výkladový prístup Sociálnej poistovne $\mathrm{k}$ tejto problematike uvádza vo svojom zverejnenom stanovisku, z ktorého vyplýva, že „nárok na výplatu materského zamestnankyña stratí, ak by mala prijem z toho istého pracovnoprávneho vztahu, z kto-

21 Pozri uznesenie Ústavného súdu SR II. ÚS 888/2014 zo dňa 11. decembra 2014.

22 Rozsudok Krajského súdu Banská Bystrica sp. zn. 20Sd/380/2014 zo dňa 22. júla 2015 a rozsudok Krajského súdu Prešov sp. zn. 5Sd/73/2015 zo dňa 28. júla 2016. 
rého jej vznikol nárok na materské“ 23 . Súčasne Sociálna poist'ovňa dodáva, že „Ak sa zamestná na dohodu, ak počas poberania dávky materské uzatvorí iný pracovnoprávny vztah u iného alebo aj pôvodného zamestnávatel'a, výplatu dávky materské jej táto skutočnost' neohrozí. Materské neohrozí ani prijem od jej zamestnávatel'a, ktorý sa viaže na obdobie pred nástupom na materskú."“

$\mathrm{V}$ d’alšom zverejnenom stanovisku Sociálna poist'ovňa len opakuje už uvedené a dodáva „Ak nejde o zamestnankyn̆u, ale o povinne poistenú samostatne zárobkovo činnú osobu alebo o dobrovol'ne nemocensky poistenú osobu, Sociálna poistovña podmienku absencie príjmu neskúma, u týchto skupín osôb nie je totiž absencia príjmu podmienkou priznania nároku na materskéc ${ }^{\text {'24. }}$.

Tento prístup Sociálnej poist'ovne je v priamom rozpore s viacerými znakmi nemocenských dávok a so všeobecnou požiadavkou na priznanie nemocenských dávok. Podl’a $\S 30$ písm. b) zákona o sociálnom poistení nárok na nemocenskú dávku (aj materské) vzniká, ak zamestnanec nemá príjem, ktorý sa považuje za vymeriavací základ na platenie poistného (na nemocenské poistenie) s výnimkou príjmu, ktorý sa poskytuje z iného dôvodu než za vykonanú prácu, a to za obdobie trvania dôvodu na poskytnutie materského.

Uvedené zákonné ustanovenie jasne vylučuje súbeh dosahovania (pravidelného) zdanitel'ného príjmu zo závislej činnosti zamestnankyne a nároku na výplatu materského. Účelom poskytovania nemocenských dávok pokrývajúcich sociálne udalosti kryté systémom nemocenského poistenia je čiastočne zmiernit' stratu príjmu v dôsledku negatívneho pôsobenia danej sociálnej udalosti na socio-ekonomické postavenie chránenej osoby ${ }^{25}$, ktorou je $\mathrm{v}$ tomto prípade tehotná poistenkyňa nemocenského poistenia a matka do konca 9 mesiaca po pôrode. Prístupom Sociálnej poist’ovne je tento účel materského značne spochybnený.

Na podporu nášho postoja podporne poukazujeme aj na jasne realizovaný zámer zákonodarcu zvyšovat' výmeru materského na úroveň „čistého“ príjmu poistenkyne, ktorý dosahovala pred vznikom nároku na materské, t. j. dávková výmera materského sa od mája 2017 zvýšila zo $65 \%$ na $75 \%$ denného vymeriavacieho základu, ktorý zjednodušene predstavuje podiel súčtu príjmov, z ktorých poistenkyňa platila poistné $\mathrm{v}$ určitom rozhodujúcom období a počtu dní tohto obdobia, za ktoré mala povinnost' platit' poistné (na nemocenské poistenie).

Ďalším argumentom je právno-teoretický poznatok o rovnakom prístupe k nemocenským dávkam z hladiska posudzovania podmienok ich priznania a výplaty (resp. realizácie ich dávkových schém) na základe rovnakých požiadaviek a pravidiel za pred-

$23<\mathrm{http}: / /$ www.socpoist.sk/aktuality-prijmy-pocas-materskej-nemusia-ohrozit-poberanie-tejto-davky $-/ 54926 c>$, navštívené dňa 10 . októbra 2018.

24 Rovnaké stanovisko Sociálnej poistovne $\mathrm{k}$ tejto problematike je zverejnené na: $<$ http://www.socpoist . sk $/ 31 / 361$ s?prm $2=60657 \&$ sword $=\&$ insurance_kind $=209 \&$ target_group $=0 \&$ life_sit $=0 \&$ kriterium $=$ all\& page $=2>$, zo dňa 11. októbra 2018 .

25 Tento účel nemocenských dávok sa najzretel'nejšie prejavuje v ich limitovanej percentuálnej výmere z denného vymeriavacieho základu, alebo v českej právnej úprave zmenou denného vymeriavacieho základu prostredníctvom nastavenia redukčných hraníc. Pozri TRÖSTER, P. a kol. Právo sociálního zabezpečení. 6. preprac. vydanie. C. H. Beck, Praha 2013. s. 116. ISBN 987-80-7400-473-5. Pozri MATLÁK, J. a kol. Právo sociálneho zabezpečenia. 2. vyd. Plzeň: Aleš Čeněk, 2012. S. 119. ISBN 978-80-7380-403-9. 
pokladu ich rovnakého alebo podobného účelu. Argumentom a contrario z uvedeného právno-teoretického poznatku a jeho analógiou založenou na uvedenom stanovisku Sociálnej poist'ovne by vo vzt’ahu k poskytovaniu napríklad nemocenského vyplynulo, že dočasne práceneschopný poistenec (zamestnanec) môže vykonávat' zárobkovú činnost' mimo pracovnoprávneho vzt’ahu, z ktorého realizácie bol zákonným spôsobom ospravedlnený po obdobie trvania dočasnej pracovnej neschopnosti. Teda v konečnom dôsledku by $\mathrm{v}$ takto hypotetickej situácii neporušoval výkonom zárobkovej činnosti lekárom nariadený liečebný režim a následne by mu v dôsledku zistenia porušenia liečebného režimu nezanikol nárok na výplatu nemocenského po obdobie najviac 30 dní trvania dočasnej pracovnej neschopnosti.

Ďalej je potrebné poukázat' aj na skutočnost', že ak žena poberajúca materské začne vykonávat' zárobkovú činnost', čo aj s právom na nepravidelný príjem zo závislej činnosti v pracovnoprávnom vzt’ahu (čo jej založí povinné dôchodkové poistenie), tak stráca postavenie poistenca štátu na účely dôchodkového poistenia, t. j. štát za ňu neplatí poistné na dôchodkové poistenie počas poberania materského (§ 128 ods. $5 \mathrm{v}$ spojitosti $\mathrm{s} 15$ ods. 1 písm. c) zákona o sociálnom poistení). Ak by z takejto zárobkovej činnosti poberala príjem zo závislej činnosti nižší ako je polovica priemernej mesačnej mzdy v hospodárstve SR, tak by jej sociálna ochrana bola nižšia než akú poskytuje štát svojim poistencom na účely získavania ich budúcich dôchodkových práv.

Pri hlbšej systémovej analýze tejto problematiky nachádzame ešte jeden argument, ktorý o nedostatočnom legislatívnom vyjadrení dávkovej schémy materského a prípadnej systémovej chybe v prepojení medzi systémom nemocenského poistenia a systémom štátnych sociálnych príspevkov určených na podporu starostlivosti a výchovy diet'at’a.

Dávková schéma materského a súčasne aj nárok na výplatu materského vyžadujú preukázanie podmienky starostlivosti o narodené diet’a, pričom úroveň tejto starostlivosti zákonodarca bližšie nedefinuje, či už na úroveň riadnej starostlivosti alebo osobnej a celodennej starostlivosti. Použitím analógie legis pri vymedzení úrovne starostlivosti o novorodenca je možné aplikovat' úroveň riadnej starostlivosti u jednej zo skupín poistencov štátu na účely dôchodkového poistenia, ktorú zákonodarca podla § 15 ods. 1 písm. c) zákona o sociálnom poistení vymedzuje ako ekonomicky neaktívnu fyzickú osobu s trvalým pobytom na území SR, ktorá sa riadne stará o diet’a do 6 rokov veku. Obsahové vymedzenie riadnej starostlivosti u tejto skupiny poistencov štátu starajúcich sa o diet’a zákonodarca reguluje legislatívno-technickým odkazom na právnu úpravu poskytovania rodičovského príspevku. Ustanovenie $\S 3$ ods. 3 a 4 zákona č. 571/2009 Z. z. o rodičovskom príspevku okrem obsahového vymedzenia riadnej starostlivosti o diet’a vyjadruje vzt'ah oprávnenej osoby $\mathrm{k}$ zaist'ovaniu riadnej starostlivosti o diet'a, a to v osobnej forme alebo v náhradnej forme prostredníctvom plnoletej fyzickej osoby alebo právnickej osoby.

Z uvedenej snahy o prepojenie systému nemocenského poistenia a systému štátnych sociálnych príspevkov na podporu starostlivosti a výchovy diet’ata, kde je premost’ovacím prvkom krytie rovnakej sociálnej udalosti, je zjavný systémový nedostatok založený iným účelom materského (nemocenskej dávky) a stanovenej kvalitatívnej úrovne starostlivosti o diet'a v období od pôrodu až do 3 rokov veku, resp. 6 rokov veku diet’at'a, ak má diet’a dlhodobo nepriaznivý zdravotný stav, na účely poskytovania rodičovského príspevku. 
Preto zastávame názor, že tento zretel’ný systémový „pat“ vyrieši iba legislatívny zásah zákonodarcu, ktorý bud' „potvrdi'“ vyššie uvedený prístup Sociálnej poist’ovne s následkom iného postavenia materského voči ostatným nemocenským dávkam, alebo legislatívne precizuje úroveň starostlivosti na účely poskytovania materského, a tak ju definične oddelí v rámci totožnej sociálnej udalosti voči nadväzujúcemu poskytovaniu rodičovského príspevku v rámci tej istej sociálnej udalosti.

Napokon k uvedenej nesystémovosti medzi systémom nemocenského poistenia a štátnych sociálnych príspevkov dodávame, že tá vznikla zmenou prístupu zákonodarcu k situácii výkonu zárobkovej činnosti oprávnenou osobou, ktorej vznikol nárok na výplatu rodičovského príspevku, a to zákonom č. 571/2009 Z. z. účinným od 1. januára 2010. Právna úprava účinná do konca roka 2009 totiž zakotvovala v definičnom vymedzení riadnej starostlivosti o diet’a ako jednej z požiadaviek na vznik nároku na výplatu rodičovského príspevku osobne (rodičom) poskytovanú starostlivost' diet’at'u v záujme jeho fyzického a psychického vývinu, pričom exemplifikatívnym spôsobom túto úroveň starostlivosti obsahovo vymedzovala.

\section{NÁSLEDKY SUBSUMPCIE KONATELA A SPOLOČNÍKA SPOL. S R.O. POD POISTNÚ KATEGÓRIU ZAMESTNANCA}

V tejto časti analyzujeme špecifiká odvodovej participácie konatel’a (a aj spoločníka) spol. s r.o. vrátane situácie vyplatenia podielu na zisku, pričom odhliadame od d'alšieho vznikajúceho teoreticko-aplikačného problému založeného nálezom Ústavného súdu ČR (sp. zn. I ÚS 190/15 zo dňa 13. septembra 2016) a z neho argumentačne vychádzajúcim rozsudkom Najvyššieho súdu ČR (sp. zn. Cdo 4831/2017) o možnosti člena štatutárneho orgánu obchodnej spoločnosti dojednat' (napr. v managerskej zmluve) podriadenie činností (ktoré nemajú podl'a obchodnoprávnych predpisov kogentnú povahu) pracovnoprávnemu režimu výkonu závislej práce podl’a Zákonníka práce, čo podnietilo diskusiu o tejto problematike aj v slovenských odborných kruhoch ${ }^{26}$. Vzhl'adom na uvedené predstavíme aj situáciu odvodovej participácie konatel'a spol. s r.o., ktorý je súčasne aj v pracovnom pomere, a teda zamestnancom spol. s r.o.

Právna úprava systému sociálneho poistenia účinná od 1. januára 2011, ktorá zaviedla priame prepojenie medzi zárobkovou činnost'ou poistnej kategórie zamestnanca a daňového vymedzenia príjmu zo závislej činnosti spôsobila, že konatelia a spoločníci spoločností s ručením obmedzením sa považujú na účely sociálneho poistenia a verejného zdravotného poistenia za zamestnanca. Táto zmena právnej úpravy spôsobila, že konatel' a spoločník spol. s r.o. majú rôznu úroveň obligatórnej (zákonnej) sociálnej ochrany v poist'ovacom systéme, ktorú dokážu menit' vlastným rozhodovaním sa, ked'že konatel' je v postavení štatutárneho orgánu a súčasne môže byt’ aj spoločníkom spol. s r.o. a d'alej aj v situácii jednoosobovej spol. s r.o..

26 Pozri k tomu BARANCOVÁ, H. Zamestnanec, štatutár a spoločník v pracovnom práve. Praha: Leges, 2018. s. 84-87. ISBN 978-80-7502-300-1. a za oblast' obchodného práva CSACH, K. Súbeh výkonu funkcie člena štatutárneho orgánu a pracovného pomeru - revolúcia na obzore? (k nálezu Ústavného súdu ČR z 13. septembra 2016). In: Súkromné právo. ISSN 1339-8652, 2017, roč. 3, č. 1, s. 2-8. 
V základnej situácii, ak konatel' spol. s r.o. (zároveň môže a aj nemusí byt' spoločníkom) nepoberá odmenu za výkon tejto funkcie, tak neparticipuje na systémoch sociálneho poistenia. V prípade systému zdravotného poistenia vzhl'adom na jeho osobitnú existenciu trvania poistného vzt’ahu a absolútnu solidaritu vyžadujúcu plnenie odvodovej povinnosti v každom období života poistenca (či priamu alebo suplovanú spravidla štátom) je konatel' v postavení samoplatitel'a poistného na verejné zdravotné poistenie ${ }^{27}$.

Opačnou situáciou a častejšou je poberanie odmeny za výkon funkcie konatel'a. Je potrebné rozlíšit', či má konatel' právo na pravidelnú mesačnú odmenu alebo nie (pri určovani pravidelnosti mesačného zdanitelného prijmu zo závislej činnosti je rozhodujúce zmluvné zakotvenie práva na pravidelný prijem s mesačnou splatnostou, nie jeho zúčtovanie či faktická výplata ${ }^{28}$ ). Ak konatel' pravidelne mesačne poberá odmenu, tak má odvodové zat'aženie rovnaké ako „klasický“ zamestnanec v pracovnom pomere. Ak je nepravidelne odmeňovaný za výkon funkcie konatel'a, tak výlučne obligatórne participuje na dôchodkovom poistení2 ${ }^{29}$, pričom ale spol. s r. o. aj ked' má postavenie zamestnávatel'a, tak neplatí úrazové a garančné poistenie a teda nie je úrazovo a garančne poistená (dôvodom je charakter obchodno-záväzkového vzt'ahu medzi konatel’om a spol. s r.o. nezlučitel'ný s účelom uvedených poistení). Osobitne dodávame, že ak je konatel'ovi s.r.o. vyplatená (nepravidelná) odmena počas kalendárneho roka, tak podl’a §139b ods. 2 zákona o sociálnom poistení sa suma tejto odmeny rozpočíta medzi jednotlivé mesiace trvania tohto poistného vzt’ahu na dôchodkovom poistení v poslednom (aktuálnom) roku až do mesiaca, ktorý predchádza mesiacu výplaty odmeny, a to až do dosiahnutia sumy maximálneho vymeriavacieho základu na platenie poistného ${ }^{30}$. Tento právny stav vytvára možnost’ úniku z plnenia odvodovej povinnosti v situácii vyplatenia vysokej odmeny prevyšujúcej sumu maximálneho vymeriavacieho základu na platenie poistného do systémov sociálneho poistenia v prvý mesiac nasledujúceho kalendárneho roka (a rozhodnút' o ich vyplatení možno aj na konci predchádzajúceho roka). Tento prístup o úniku z plnenia odvodovej povinnosti je taktiež aplikovatelný na vysokopríjmové skupiny zamestnancov ${ }^{31}$.

27 Samoplatitel' poistného na verejné zdravotné poistenie je osobou, ktorá nemá postavenie zamestnanca, ani SZČO a ani poistenca štátu, pričom jej odvodová povinnost' predstavuje $14 \%$ z polovice priemernej mesačnej mzdy v hospodárstve SR platnej pred dvoma rokmi (pre rok 2018 je to suma 63,84€ určená ako 14 \% (912/2)). Polovičná percentuálna sadzba sa vzt’ahuje na platitel’ov poistného so zdravotným postihnutím (či v postavení invalidnej osoby alebo fyzickej osoby s t’ažkým zdravotným postihnutím).

28 Túto interpretáciu podporuje aj stanovisko Sociálnej poist'ovne: „Za zamestnanca v právnom vzt’ahu, ktorý mu zakladá právo na nepravidelný príjem, sa považuje konatel', ak nemá právo na príjem zo závislej činnosti pravidelne za každý kalendárny mesiac, ale napr. jednorazovo raz ročne, raz štvrtročne, raz za dva mesiace. "Dostupné online na: $<$ https://www.socpoist.sk/poradna-pre-eu/1232s?prm2=47630\&sword $=\&$ insurance_kind $=0 \&$ target_group $=0 \&$ life_sit $=0 \&$ kriterium $=$ all\&page $=24 \&$ set_subframe $=$ blind $>$, navštívené dňa 29. septembra 2018.

29 Poistné na dôchodkové poistenie sa skladá z poistného na starobné poistenie (4 \% zo sumy odmeny platí konatel' a $14 \%$ zo sumy odmeny spol. s r.o.), poistného na invalidné poistenie (po $3 \%$ zo sumy odmeny tak konatel' ako aj spol. s r.o.) a poistné do rezervného fondu solidarity (4,75\% iba spol. s r.o.).

30 Schéma definujúca maximálny vymeriavací základ na platenie poistného je 7-násobok priemernej mesačnej mzdy v hospodárstve SR platnej pred dvoma rokmi, čo pre rok 2018 znamená hranicu $6383 €$ a pre rok 2019 hranicu $6678 €$.

31 Uvedená možnost' zákonodarcom tolerovaného úniku z pod „,plnej“ odvodovej povinnosti na účely sociálneho poistenia je už dlhšie predmetom odborných diskusií. Napr. pozri úvod článku dostupného online na: $<$ https://www.iness.sk/sk/rocne-zuctovanie-moze-priniest-nespravodlivost-trend>, navštívené dňa 5. 9. 2018. 
Na účely platenia poistného na zdravotné poistenie z vyplatenej nepravidelnej odmeny konatel'ovi sa odvodová situácia komplikuje. Z vyplatenej odmeny za daný mesiac platí konatel' a aj spol. s r.o. ako zamestnávatel' preddavky na zdravotné poistenie a v mesiacoch, v ktorých nemá konatel' právo na odmenu sa považuje za samoplatitel'a poistného na zdravotné poistenie. Takto zákonodarcom navodený právny stav vytvára priestor pre špekulatívne správanie, ked’že konatel' je kompetenčne spôsobilý navodit' vel'mi nízku sumu odmeny vyplácanú pravidelne, čím „obíde“ zákonodarcom určenú minimálnu sumu preddavku na zdravotné poistenie, ktorú by musel odvádzat' v postavení samoplatitel'a poistného a aj v porovnaní s ,klasickým“ zamestnancom odmeňovaným v pracovnom pomere minimálnou mzdou (v roku 2018 je to mesačná minimálna mzda $480 €$ pre 1 . stupeň náročnosti práce a minimálna hodinová je $2,759 €$ pre 1 . stupeň náročnosti práce; v roku 2019 je mesačná minimálna mzda $520 €$ a minimálna hodinová mzda pre 1. stupeň náročnosti práce $2,989 €$ ). A v konečnom dôsledku má konatel' v takto navodenom stave vyplácania „nízkych odmien“ nárok na rovnakú úroveň (kvalitu) poskytovanej zdravotnej starostlivosti ako iní poistenci, ktorí riadne platia poistné na zdravotné poistenie zo svojich miezd a platov či iných druhov príjmov zo závislej činnosti.

Ked’že v posledne uvedených dvoch situáciách konatel'ovi spol. s r.o. vzniká povinné poistenie v systémoch sociálneho poistenia, tak je potrebné určit' vznik/zánik poistného vzt'ahu u konatel'a s pravidelnou alebo nepravidelnou vyplatenou odmenou, pričom rozhodujúcou skutočnost'ou je deň zápisu vykonávania funkcie do obchodného registra ${ }^{32}$. Uvedený interpretačný prístup potvrdzuje aj stanovisko Sociálnej poist'ovne, podl'a ktorého „Konatel' (a aj spoločník) spol. s r.o. nadobudne postavenie zamestnanca na účely sociálneho poistenia iba v prípade, ak mu vznikne právny vzt’ah konatel'a alebo spoločníka zápisom do obchodného registra, a zároveñ, ak mu určitý úkon (napríklad mandátna zmluva, zmluva o výkone funkcie) zaručuje právo na príjem zo závislej činnosti za prácu konatel'a alebo spoločníka. Pritom nie je rozhodujúce, či spoločník alebo konatel' má odmenu skutočne vyplatenú. Dôležité je, že má právo na tento príjem. ${ }^{33}$.“ Špecificky by sa postupovalo v prípade, ak konatel' vykonáva funkciu bez nároku na odmenu a valné zhromaždenie spoločnosti by prijalo rozhodnutie o priznaní jednorazovej odmeny konatel'ovi. V takom prípade by konatel'ovi vzniklo povinné dôchodkové poistenie zamestnanca prijatím rozhodnutia valného zhromaždenia.

V systéme (verejného) zdravotného poistenia uvedené nie je potrebné skúmat', ked’že poistný vzt'ah vzniká spravidla narodením a končí smrtou, a teda dochádza len k zme-

32 V súvislosti s určovaním vzniku a zániku poistného vzt’ahu (vzt’ahov) v systémoch sociálneho poistenia bolo v určitých kruhoch diskutabilné, či poistný vzt’ah vzniká vznikom právneho vzt’ahu, ktorý zakladá právo na takýto príjem ale až faktickým vyplatením príjmu či vzdaním sa nároku na príjem/odmenu. Pozri rozsudok Krajského súdu Banská Bystrica sp. zn. 20Sd/380/2014 zo dňa 22. júla 2015. V tomto rozsudku sú dôvodí, že ,pre vznik a trvanie postavenia zamestnanca s nepravidelným príjmom na účely dôchodkového poistenia nepostačuje sama o sebe skutočnost', že osoba je v právnom vzt’ahu, ktorý jej zakladá právo na nepravidelný prijem bez ohl'adu na to, že či sa (tohto) práva vzdala alebo nie, ktorá zastáva odporkyňa“. A následne dodáva, že ,podl'a názoru súdu pre splnenie podmienky postavenia zamestnanca, okrem právneho vzt’ahu je potrebné naplnit' aj materiálny obsah tohto vzt’ahu“. Tento ojedinelý judikatórny prístup bol ale odmietnutý rozsudkom Najvyššieho súdu SR sp. zn. 10So/54/2013 z 28. mája 2014 aj uznesením Ústavného súdu SR II. ÚS 888/2014 zo dňa 11. decembra 2014.

33 Dostupné online na: <https://www.socpoist.sk/poradna/326s?prm2=55322\&sword=\&insurance_kind $=260 \&$ target_group=0\&life_>, navštívené dňa 10 . septembra 2018 . 
ne platitel'a poistného, ak napríklad $\mathrm{v}$ predchádzajúcom roku nemal konatel' vyplatenú žiadnu odmenu alebo bol v evidencii uchádzačov o zamestnanie. Uvedené vo vzt'ahu $\mathrm{k}$ vyplatenej odmene obdobne platí aj pre spoločníka spol. s r.o.

Predposlednou skutkovou situáciou je variant, že konatel' (bez ohl'adu či je alebo nie je spoločníkom) s právom na vyplatenie (resp. pravidelné vyplácanie) odmeny nadobudne postavenia zamestnanca z titulu uzatvorenia pracovnoprávneho vzt’ahu. V tejto situácii sa na účely participácie $\mathrm{v}$ systémom sociálneho poistenia posudzuje každý právny vzt’ah regulujúci tak postavenie konatel'a ako aj postavenie zamestnanca samostatne, pričom pravidelnost' odmeny a mzdy bude rozhodujúca na posúdenie rozsahu odvodovej participácie v sociálnom poistení. Vo verejnom zdravotnom poistení má fyzická osoba s vyplácanou odmenou konatel'a spol. s r.o. a s vyplácanou pracovnoprávnou mzdou (odmenou) vždy postavenie zamestnanca bez potreby d'alšieho rozlišovania postavenia.

Napokon uvádzame právne riešenie situácie vyplatenia podielu na zisku (poznamenávame, že dividenda nie je príjmom zo závislej činnosti) konatel’ovi, ktorému je vyplatená (resp. pravidelne vyplácaná) odmena a ktorý je bud’ aj spoločníkom spol. s r.o. alebo ním nie je. Ak konatel' nie je spoločníkom spol. s r.o., tak vyplatený podiel na zisku podlieha podla $§ 138$ ods. 1 zákona o sociálnom poistení odvodovej povinnosti, a to len na účely dôchodkového poistenia za predpokladu, že konatel' má právo len na nepravidelne vyplácanú odmenu; inak aj na účely nemocenského poistenia a poistenia v nezamestnanosti. Ak konatel' vo vyššie uvedenom skutkovom postavení je spoločníkom spol. s r.o., tak vyplatený podiel na zisku nepodlieha odvodovej povinnosti na účely sociálneho poistenia. Ak konatel’ nemá právo na vyplatenie/vyplácanie odmeny a je mu vyplatený podiel na zisku, je právne irelevantné či má postavenie spoločníka a podiel na zisku v absolútnom vyjadrení nepodlieha odvodovej povinnosti na účely sociálneho poistenia. Ak je spoločníkovi spol. s r.o. vyplatený podiel na zisku, tak tento podiel na zisku nezakladá odvodovú povinnost’ na účely sociálneho poistenia. Poznamenávame, že podiel na zisku vyplatený z účtovného roka 2017 nepodlieha odvodovej povinnosti na účely zdravotného poistenia (bližšie $k$ tomu pozri poznámku pod čiarou č. 7).

Dodávame, že ak konatel' spol. s r.o. je aj spoločníkom a poberá odmenu za výkon funkcie konatel'a a aj odmenu spoločníka na základe práva na odmenu (zakotvenú v spoločenskej zmluve), tak každý právny vzt’ah regulujúci jeho postavenie konatel’a a postavenie spoločníka s právom na odmenu sa posudzuje na účely participácie v systémoch sociálneho poistenia samostatne. Vo verejnom zdravotnom poistení má fyzická osoba s vyplácanou odmenou tak pre spoločníka a ako aj konatel'a spol. s r.o. vždy postavenie zamestnanca bez potreby rozlišovania postavenia $\mathrm{v}$ spoločnosti.

Na komplikovanú a obtiažne prehl'adnú právnu úpravu poistno-odvodovej participácie konatela (a aj spoločníka) spol. s r.o. s právom na výplatu nepravidelnej odmeny (príp. podielu na zisku) musela zareagovat' aj právna úprava dávkových vzt’ahov dôchodkového poistenia. Podla $\S 60$ ods. 6 zákona o sociálnom poistení nie je hodnoteným obdobím dôchodkového poistenia na účely výmery dôchodkovej dávky obdobie dôchodkového poistenia zamestnanca, v ktorom nemal vymeriavací základ na platenie poistného. Toto pravidlo reflektujúce na prevalenciu zásluhovosti pri výmere dôchodkových dávok predstavuje v tomto prípade opodstatnené zníženie úrovne sociálnej ochrany, 
ktorú by ale mohol zákonodarca de lege ferenda zmiernit' zakotvením možnosti doplatenia poistného na dôchodkové poistenie s účinkom ex tunc ako tak urobil už v štyroch taxatívne vymedzených prípadoch (uvedených $v$ \$ 142 ods. 3 zákona o sociálnom poisteni).

\section{ZÁVER}

Súčasný pracovnoprávny prístup $\mathrm{k}$ identifikácii znakov závislej práce sa odvíja od pojmových znakov „typického“ zamestnanca (vyvodzovaných z materiálnych okolností jej výkonu), ktoré bez vážnych pochybností určia v spoločenských vzt’ahoch realizujúcich právo na (závislú) prácu také indikátory, ktoré oddelia výkon závislej práce od iných samostatných foriem výkonu práce. Tento prístup sa preberá aj do výstavbových prvkov systémov sociálnej ochrany, a to previazaním účasti (resp. participácie) vo všeobecných systémoch sociálnej ochrany pokrývajúcich podstatnú čast' katalógu sociálnych udalostíi ${ }^{34} \mathrm{~s}$ výkonom najvýznamnejších druhov zárobkovej činnosti ${ }^{35}$, ktorou rozhodne je závislá práca reprezentovaná určitými skupinami zamestnancov selektovanými podla kritéria potreby zaručenia (primeranej) sociálnej ochrany. Tento výstavbový prístup sa vo vztahu k osobnému rozsahu príspevkových systémov sociálnej ochrany SR aplikoval do konca roka 2010 a následne bol nahradený vo vzt’ahu k poistným kategóriám zamestnanca a samostatne zárobkovo činnej osoby prepojením na daňovú klasifikáciu príjmov zo zárobkovej činnosti.

Rozsiahle a možno povedat' až maximalistické zapojenie početných skupín fyzických osôb do príspevkovej (odvodovej) participácie na účely sociálneho poistenia a verejného zdravotného poistenia SR vykonané v období rokov 2011 až 2013 prinieslo, okrem vy̌šsej poistnej akumulácie, nie zanedbatel'né nedostatky, ktoré majú prevažne systémový a vecný charakter vo vzt’ahu k existujúcemu nastaveniu poistných ale aj dávkových vzt’ahov systému sociálneho poistenia.

V jadre príspevku bola analyzovaná pojmová redefinícia poistnej kategórie zamestnanca, ktorá priniesla „pseudo“ sociálnu ochranu (zakrývajúca iba snahu o vyššiu alokáciu poistného) fyzickým osobám vykonávajúcim prácu na základe dohôd o prácach vykonávaných mimo pracovného pomeru v podobe t’ažkopádnosti legislatívnej úpravy a neúčelnosti (čo do výšky dosahovaného príjmu a čo do ich krátkodobosti s výnimkou ich ,retazenia/opakovania "), d’alej systémový nedostatok v prepojení na dávkové vzt’ahy realizujúce výplatu materského a predčasného starobného dôchodku a napokon len obtiažne prehladnú, $v$ určitom aspekte plnenia odvodovej povinnosti verejného

34 Minimálny rozsah katalógu sociálnych udalostí je obsiahnutý v Dohovore MOP č. 102 o minimálnej norme sociálneho zabezpečenia z roku 1952, ktorý bol publikovaný ako Oznámenie Federálneho ministerstva zahraničných vecí č. 461/1991 Zb. a pre ČSFR záväzný od 11. januára 1991 s výnimkou podpory v nezamestnanosti a dávok pri pracovných úrazoch a chorôb z povolania.

35 Tento prezentovaný prístup podporujeme vymedzením okruhu chránených osôb pri jednotlivých sociálnych udalostiach zakotvených v dohovore MOP č. 102 alebo dohovore č. 128 o invalidných, starobných a pozostalostných dávkach z roku 1967, ktorý bol publikovaný ako Oznámenie Federálneho ministerstva zahraničných vecí č. 416/1991 Zb. a pre ČSFR je záväzný od 11. januára 1991 iba v jeho časti III. 
zdravotného poistenia až špekulatívnu, právnu úpravu postavenia konatel’a (a aj spoločníka) spol. s r.o. ako obsahovej súčasti uvedenej poistnej kategórie.

Tieto nedostatky predznačujú nel'ahkú legislatívnu a systémovo-výstavbovú cestu pri zachovaní funkcií príspevkových systémov sociálnej ochrany, ktorá sa už v tomto období očakáva zo strany informačných technológií prostredníctvom ktorých sa začína uskutočňovat' výkon (doterajšej) závislej práce. Už len jedna významná zmena, akou bolo definičné previazanie poistnej kategórie zamestnanca na daňovú klasifikáciu príjmov zo závislej činnosti, dokázala vyvolat' kontroverzie či nedostatky v nastavení a funkciách sociálnopoistovacieho právneho vzt’ahu v podmienkach SR, čo potom možno očakávat' od nastavení vyvolaných novými digitálnymi platformami výkonu zárobkovej činnosti, ktoré okrem iného oslabia aj súčasné bazálne znaky závislej práce. A súčasné nedostatky v systémovom nastavení sociálnopoistovacieho právneho vzt’ahu, v ktorom je subjektom osoba vykonávajúca činnost' na základe dohôd o prácach vykonávaných mimo pracovného pomeru a konatel' spol. s r.o. (najmä ak nemá majetkovú účast' na spoločnosti), pritom nie sú vyvolané fenoménom nových informačných technológií, ale sú výsledkom nedoriešeného vzt’ahu medzi „typickým“ pracovným pomerom (výkonom závislej práce) a výkonom činností, ktoré sú na pomedzí výkonu závislej práce a podnikania (najmä obchodnoprávnych vzt’ahov), a to minimálne v dôsledku vol’nejšieho rozhodovania o niektorých dimenziách výkonu závislej práce. Je preto nevyhnutné pri vysporiadavaní sa s uvedenou reláciou „klasický/typický“ zamestnanec a člen štatutárneho orgánu identifikovat' a zohl'adnit' znaky nových zmiešaných (resp. digitálnych) foriem výkonu práce a vo výsledku zvážit vytvorenie modelu tzv. ekonomicky (resp. hospodársky) závislých osôb, s ktorým by sa spájala určitá (primeraná36) úroveň sociálnoprávnej ochrany týchto osôb. Rozhodne bude predmetom diskusie rozsah a forma participácie v príspevkových systémoch sociálnej ochrany vzhl'adom na v niektorých prípadoch problematické objektivizovanie dosahovaného príjmu vrátane jeho prevažujúcej pravidelnosti (obdobou tohto očakávaného stavu je v súčasnosti činnost' (výkonného) umelca a autora a ich odvodová participácia v sociálnom poistení $v$ postaveni samostatne zárobkovo činnej osoby).

V konečnom dôsledku slovenský zákonodarca prvý výrazný krok k verifikácii hospodárskej závislosti naznačenej novej kategórie „kvázi““ zamestnancov uskutočnil vyššie uvedenou redefiníciou poistnej kategórie zamestnanca spojenou s rovnako extenzívnym vymedzením zamestnávatel’a. Ďalší krok, ktorým je zavedenie modelu ročného zúčtovania v systéme sociálneho poistenia (od roku 2005 sa aplikuje vo verejnom zdravotnom poisteni), pripravil s predpokladanou účinnost'ou od roku 2021. Zastrešenie určitou (primeranou) úrovňou sociálnej ochrany všetkých foriem pracovnoprávnych vzt'ahov (vrátane kategórie zamestnancov platforiem) akcentuje vo svojej preambule a v zásade č. 12 Európsky pilier sociálnych práv ${ }^{37}$ a aj samotná podstata a ciel' návrhu Odporú-

${ }^{36} \mathrm{~K}$ primeranosti sociálnej ochrany pozri aj bod č. 16 návrhu Odporúčania Rady o prístupe k sociálnej ochrane pre pracovníkov a samostatne zárobkovo činné osoby, ked’že obsahuje generálne rámcové kritériá ako je dôstojná životná úroveň, dôstojný život, nadobudnutie vhodnej náhrady za stratu na príjme, ochrana pred prepadom do chudoby.

37 Pilier sociálnych práv bol vyhlásený a podpísaný Európskou komisiou, Európskym parlamentom a Radou EÚ dňa 17. novembra 2017 na Sociálnom summite pre spravodlivé pracovné miesta a rast v Göteborgu. 
čania Rady o prístupe k sociálnej ochrane pre pracovníkov a samostatne zárobkovo činné osoby (COM(2018) 132 final). Oba zmienené dokumenty kladú na národného zákonodarcu náročnú úlohu monitorovat’ súčasnú dosiahnutú úroveň sociálnej ochrany zamestnanca a následne ju v prípade deformácie hospodárskymi (a aj technologickými) trendmi dorovnávat' $\mathrm{v}$ prospech zaistenia primeranej sociálnej ochrany zamestnanca v každom druhu pracovnoprávneho vzt’ahu, čo v prípade miestami prekomplikovanej slovenskej právnej úpravy sociálnej ochrany určitých kategórií zamestnancov bude spojené s väčšími t'ažkost’ami.

doc. JUDr. Miloš Lacko, Ph.D.

Katedra pracovného práva a práva sociálneho zabezpečenia

Právnická fakulta Trnavskej univerzity v Trnave

milos.lacko@gmail.com 


\title{
DORUČOVÁNÍ PÍSEMNOSTÍ \\ A ELEKTRONICKÝ PRÁVNÍ STYK V PRACOVNĚPRÁVNÍCH VZTAZÍCH
}

\author{
JÁN MATEJKA*
}

Abstrakt: Delivery of documents and electronic communication in labour law relations

The current legal framework for contracting in labour law is certainly traditional and in the spirit of fundamental labour law principles sufficiently protective. In terms of modern, flexible or other standard forms of electronic legal relations it must also be critically examined as the wide application of protection regulation is usually an obstacle to further development of modern forms of legal relations. The development of the information society presupposes an effective, legally permitted and demonstrably reliable tool enabling an efficient electronic legal contact and archiving of related electronic records. It is precisely electronic documents that form the dominant part of the most standard contractual processes including labour law. The simplicity, quickness, ergonomics and overall efficiency of these tools not only lead to the use of electronic documents more often than paper documents, but also to the fact that electronic documents are used where traditional forms of legal action based on documentary record have been used. The purpose of this article is to offer a certain perspective and to stimulate a discussion on the issue of the current construction of the implementation of electronic written legal proceedings in labour law based on a certain mandatory limitation that "if the legal action has not been delivered, it does not exist" in favour of the related, although at the same time contradictory but civilistic, in many respects, more appropriate thesis, according to which it must be delivered to the sphere of disposition of the other contracting party.

Keywords: delivery; documents; labour law relatons; flexibility; e-signature; formal requirements; proofs; e-documents; reliability of proof

Klíčová slova: doručování; písemnost; pracovněprávní vztah; flexibilita; elektronický podpis; formální náležitosti; prokazování; elektronický dokument; důkazní spolehlivost

DOI: $10.14712 / 23366478.2019 .5$

* Autor působí na Ústavu státu a práva Akademie věd ČR, v. v. i. a na Matematicko-fyzikální fakultě Univerzity Karlovy, je též advokátem v Praze. Příspěvek vznikl za podpory projektu Grantové agentury České republiky č. 16-26910S s názvem Biometrické údaje a jejich zvláštní právní ochrana (Biometric Data and Their Specific Legal Protection). 


\section{1. ÚVODEM K DORUČOVÁNÍ PRACOVNĚPRÁVNÍCH PÍSEMNOSTÍ}

V pracovněprávních vztazích již tradičně platí, že projev vůle vyvolává sledované právní následky jen tehdy, pokud byl doručen relevantním subjektům pracovněprávního vztahu ${ }^{1}$; účinky těchto právních jednání jsou tak podmíněny dodržením relativně striktního formálně-procesního postupu spočívající v řádném doručení, jehož podrobná úprava je včleněna do části třinácté zákoníku práce, konkrétně pak ustanovení §334-337. Svou podstatou tak jde o úpravu speciální, nebot'v obecné rovině občanský zákoník pravidla tohoto typu neobsahuje. Tato úprava tak vychází jak z existujících pracovněprávních zásad, zejména pak ochranné funkce, tak i z existující praxe a relativně ustálené judikatury.

Bez ohledu na konkrétní formu právního jednání tak zákoník práce upravuje, kromě obecných ustanovení o doručování zaměstnavatelem (§ 334), také tři samostatné způsoby doručování písemností zaměstnavatele zaměstnanci, a to:

- osobní doručení zaměstnavatelem ve smyslu ustanovení $§ 334$ odst. 2 (ve spojení s odst. 3 zákoníku práce);

- doručování prostřednictvím sítě nebo služby elektronických komunikací, tedy zpravidla cestou elektronické pošty ve smyslu ustanovení § 335 zákoníku práce;

- doručování prostřednictvím provozovatele poštovních služeb (ve smyslu § 336 ve spojení s § 334 odst. 4).

$\mathrm{Z}$ uvedeného výčtu je zřejmé, že pracovněprávní úprava preferuje osobní doručení př́mo zaměstnavatelem, resp. pověřeným zástupcem zaměstnavatele, před ostatními způsoby doručování. ${ }^{2}$ Jakkoliv je zde patrná určitá snaha zákonodárce o jistou komplexnost, resp. uzavřenost všech těchto způsobů doručování, je zřejmé, že zde uvedené způsoby doručování nejsou popsány s rovnoměrnou mírou detailu, jasnosti a zejména přesností zpracování; v některých aspektech tak nutno důsledně zvážit, zda a pokud ano, tak do jaké míry lze tyto způsoby doručování rozšiřovat o jiné související formy realizované v mezích a na základě této speciální právní úpravy. Př́íkladem hodným takové zvláštní úvahy je doručování resp. realizace elektronických písemností, jež bude dále předmětem tohoto článku.

Samotný zákoník práce s pojmem elektronická písemnost výslovně nepracuje, upravuje pouze obecně doručování prostřednictvím sítě nebo služby elektronických komunikací, a to bud' zaměstnanci (§ 335) nebo zaměstnavateli (\$337); s ohledem na definiční podstatu ${ }^{3}$ služeb či sítí elektronických komunikací. Lze dovodit, že takto lze doručit

1 K tomu více viz např. DRÁPAL, L. § 334 [Obecné ustanovení o doručování zaměstnavatelem]. In: BĚLINA, M. - DRÁPAL, L. - BĚLINA, T. - BOGNÁROVÁ, V. - DOLEŽÍLEK, J. - NOVOTNÝ, Z. PICHRT, J. - PUTNA, M. - ROTHOVÁ, E. - STÁDNÍK, J. - ŠTEFKO, M. Zákoník práce. 2. vyd. Praha: Nakladatelství C. H. Beck, 2015, s. 1361. ISBN 978-80-7400-290-8.

$2 \mathrm{~K}$ tomu srovnej celkový kontext a účel ustanovení $§ 334$ odst. 2 zákoníku práce.

3 K tomu viz ustanovení § 2 zákona č. 127/2005 Sb., zákona o elektronických komunikacích, ve znění pozdějších předpisů. 
pouze elektronickou písemnost. Na doručování písemností touto cestou klade zákoník práce poměrně prrísné podmínky, a to ( $\mathrm{v}$ př́ípadě doručování zaměstnanci $\left.{ }^{4}\right)$ :

- písemný souhlas zaměstnance,

- poskytnutí elektronické adresy pro doručování ze strany zaměstnance,

- opatření doručované písemnosti uznávaným elektronickým podpisem zaměstnavatele ${ }^{5}$,

- potvrzení zaměstnance o přijetí doručované písemnosti, které zaměstnanec opatří svým uznávaným elektronickým podpisem nikoliv později než do 3 dnů od odeslání písemnosti.

Účinky takto doručovaných písemností tak nastanou až po dodržení shora uvedeného formálně-procesního postupu, $\mathrm{v}$ opačných př́padech půjde o jednání neúčinné. Takto striktní požadavek zákonodárce klade na smluvní strany velmi vysoké požadavky, což ve svém důsledku zpravidla vede jednak k nevyužívání této možnosti (s důvodů své celkové komplikovanosti a obtížné splnitelnosti), př́ípadně k samotnému ohrožení všech budoucích účinků tohoto jednání (v př́ípadě jejich nedůsledného použití); nehledě pak na skutečnost, že úprava tak ve svém důsledku téměř eliminuje většinu efektů komunikace $v$ elektronické podobě mezi smluvními stranami, čímž ve svém důsledku dochází k ohrožení celkového elektronického pracovněprávního styku.

Předmětná úprava však trpí ještě jedním nedostatkem, navzdory své relativní komplexnosti totiž nepočitá $\mathrm{s}$ tím, že by elektronické pracovněprávní písemnosti mohly být doručovány (či přesněji realizovány) i jiným způsobem než jen prostřednictvím služby či sítě elektronických komunikací, a to napřr. vytvořením (generováním) a vzájemným předáním elektronické písemnosti přímo $\mathrm{v}$ místě sídla zaměstnavatele, tedy jakýmsi doručením elektronické písemnosti svého druhu (formou osobního předání).

Absence této výslovné možnosti realizace právních jednání patrně nepředstavuje nic jiného než projev ochranné funkce pracovního práva, nicméně ve svém důsledku zde nedochází k ochraně slabší stranu pracovněprávního vztahu, ale spíše naopak, k výraznému omezení možností efektivní elektronické komunikace, a to včetně možnosti garance důkazní spolehlivosti elektronických dokumentů, která mohou poskytovat kvalitativně výrazně vyšší důkazní jistotu než tradičně využívané vlastnoručně podepisované listiny. Zákoník práce tak připravuje své adresáty (včetně chráněného zaměstnance) o celou řadu v soukromém právu již využívaných možností, jejichž použití přináší celou řadu výhod, jež v mnoha ohledech mohou vyvážit existující rizika.

V tomto ohledu je proto nezbytné připomenout některé existující možnosti realizace soukromoprávních písemností, a to včetně vybraných aspektů vyplývajících z práva Evropské unie, případně současného občanského zákoníku, včetně tradičního podpisu soukromých písemnosti, resp. určité jeho elektronické alternativy jako svého druhu elektronické obálky v podobě podpisu elektronického, a některých souvisejících as-

4 Konstrukce doručování zaměstnavateli je dle § 337 v zásadě obdobné, nicméně zákoník práce předpokládá určitá méně významná specifika (viz např. možnost elektronického pečetění dle §337 odst. 3 zákoníku práce, apod.)

5 Dle $\S 6$ odst. 2 a $\S 9$ odst. 2 zákona č. 297/2016 Sb., o službách vytvářejících důvěru pro elektronické transakce, ve znění pozdějších předpisů. 
pektů týkajících se vyvratitelné právní domněnky spolehlivosti záznamů o právních jednáních obsažených v elektronickém systému.

Řešení těchto problémů je nutno hledat nejenom v ustálené praxi, ale především v analýze souvisejících ustanovení české i evropské právní úpravy, konkrétně pak v nařízení Evropského Parlamentu a Rady (EU) č. 910/2014 o elektronické identifikaci a službách vytvářejících důvěru pro elektronické transakce na vnitřním trhu (dále jen nařízení eIDAS), v zákoně č. 297/2016 Sb., o službách vytvářejících důvěru v elektronických transakcích, ve znění pozdějších předpisů (dále jen ZoSVD), tak i v ustanovení zákona č. 89/2012 Sb., občanského zákoníku.

\section{TRADIČNÍ VÝZNAM PODPISU NA SOUKROMÝCH LISTINÁCH}

O tradičním významu podpisu v soukromoprávních vztazích toho bylo napsáno relativně mnoho ${ }^{6}$, podpis totiž ve všech jeho heterogenních podobách představoval určitou součást většiny významných aktů realizovaných ve společenském, kulturním či právním styku. Samotný význam podpisu se však v historickém ${ }^{7}$ i současném ${ }^{8}$ kontextu konzistentně opírá zejména o pevný normativní fakt, že podpis jednající osoby je předpokladem platnosti písemných právních jednání (typicky smluv, deklarací, apod.). Tento základní význam podpisu písemné formy právních jednání pak tvoří samotnou normativní podstatu podpisu pro soukromoprávní vztahy, a to včetně vztahů obchodních či pracovních. U veřejnoprávních úkonů jako je např. podání vůči státu, apod., však platí zcela jiné podmínky. Tato dichotomie režimu soukromoprávních a veřejnoprávních úkonů je kromě zjevných historických důvodů způsobena především rozdílem v podstatě těchto vztahů, jakož i v nerovnosti jejich jednotlivých subjektů (k tomu viz níže).

$\mathrm{V}$ dnešním současném pojetí však podpis navenek osvědčuje, resp. stvrzuje určitý akt, typicky právní jednání (např. uzavření smlouvy, potvrzení nějaké skutečnosti, projev vůle osoby, apod.). Písemná forma právního jednání tedy kromě jiných obecných náležitostí ${ }^{9}$ vyžaduje, aby byl př́ílušný projev vůle zachycen na médiu, které má

6 Viz např. ELIÁŠ, K. Právní úkony na soukromých listinách se zvláštním zretelem k jejich podepisování. AD NOTAM, 1996, č. 3, s. 53; MATEJKA, J. Úprava elektronického podpisu v právním řádu ČR, Právník, 2001, 4, 5, s. 582-611; MATEJKA, J. K využití elektronického podpisu v pracovněprávních vztazích, Právo a zaměstnání, 2001, 4. 5, s. 5-11; MATEJKA, J. Vybrané právní překážky elektronického obchodu, Parlamentní zpravodaj, 2002, 4. 3, s. 12-13; případně novější práce KORBEL, F. - MELZER, F. Písemnost, elektronický a biometrický podpis v elektronickém právním jednání, Bulletin advokacie, 2014, 4. 12, s. 31, apod.

7 Viz již neplatný § 40 odst. 3 zákona č. 40/1964 Sb., občanského zákoníku.

8 Uvedená konstatace vyplývá z ustanovení § 561 odst. 1 zákona č. 89/2012 Sb., občanského zákoníku, jež, ve své podstatě přejímá předchozí úpravu z roku 1964, kdy právní jednání bude učiněno v písemné formě za splnění dvou základních předpokladů, kterými jsou písemnost a podpis jednajícího.

9 Jako např. svoboda, vážnost, určitost a srozumitelnost právního úkonu, včetně právně způsobilého subjektu, apod.

Dále pro úplnost nutno zohlednit rovněž problematiku právního jednání vůči „nepřítomnému“ zaměstnanci, jež není v současné pracovněprávní úpravě rovněž dostatečně komplexně řešena, resp. poskytuje př́lišs velký prostor pro př́ipadné zneužití práv zaměstnance, resp. přesněji ochranné funkce (na úkor funkce organizační). Určitou rozumnou inspirací by v tomto ohledu mohla být, byt' i jen částečná, aplikace usta- 
a) právní povahu písemnosti (listiny) a dále pak b) aby byl tento projev vůle podepsán. Uvedené však platí výlučně pro vztahy soukromoprávní (vymezené zejména občanským zákoníkem), o poznání jiný režim je pak dán např. režimem zákoníku práce, který obsahuje relativně zvláštní právní úpravu, zcela jiný je pak režim veřejnoprávních předpisů upravujících komunikaci s orgány veřejné moci.

Jak ostatně vyplývá z výše uvedeného, jako velmi podstatné se zdá být doktrinálně vhodné vymezení pojmu písemnost (resp. listina) a podpis. O tom, co je listina v právním slova smyslu, neobsahuje náš právní řád jedinou výslovnou zmínku. Řada zákonných ustanovení však o listině poměrně často hovoří. Legální definice listiny ale v platné právní úpravě obsažena není. Právní jednání tak musí být zachyceno písemně na jakémkoliv hmotném či nehmotném nosiči, přičemž pro platnost právního jednání není rozhodné, jaké písmo či jazyk byl použit. Co se náležitostí na formu právního jednání týče, je nutno souhlasit s tradiční právní doktrínou ${ }^{10}$, že nejde o vytýkatelný nedostatek právní úpravy, a že je tento problém řešitelný vcelku úspěšně teoreticky. Literatura i praxe se navíc shodly, že za listinu lze považovat (kromě běžných listin papírových) jakékoliv jiné hmotné médium, (např. kůra, kámen či hliněná tabulka) na něž lze zachytit písemný projev, př́p. cokoliv jiného, na čem může být písmo zachyceno s tím, že je lhostejno, ,na jaké látce a jakou látkou“11 je projev vůle sepsán (tedy např. text zachycený rytbou na bronzovou sochu, příp. v písku na písečné pláži či na zahrádce z květin). Obecně lze tedy konstatovat, že listinou, resp. písemností se v našem právním řádu tedy rozumí cokoliv psaného. Dále je zde třeba souhlasit s ustáleným názorem právní praxe, ${ }^{12}$ podle které ,teoretické spory kolem listiny nemaji praktického významu“. ${ }^{13}$

Písemná forma právního úkonu tak nepředpokládá pouhé zachycení obsahu právního jednání v textu listiny (písemnosti), ale dále také existenci podpisu.). Obdobně, jak je tomu v prŕípadě pojmu „listina“, neobsahuje náš právní rád legální definici pojmu ,podpis“. To však již může přinášet řadu jak praktických tak i teoretických problémů. Jednak není př́iliš jasné, jak úplný podpis je z hlediska práva ještě dostatečný a jaký již nikoliv. Nejenom, že není zdaleka zrrejmé, zda postačuje podpis typu „Váš otec“, příp. „Tvůj bratr “, ale ani nelze zcela jednoznačně odpovědět na otázku, zda postačuje stro-

novení § 570 občanského zákoníku upravující právní jednání působí vůči nepřítomné osobě. Současná judikatura Nejvyššího soudu však jde, zdá se, jinou cestou, když v tomto ohledu navíc relativně striktně ve smyslu netriviální úpravy v zákoníku práce dovozuje, že „Pro posouzení, zda v konkrétním prípadě nebylo možné, aby zaměstnavatel písemnost určenou do vlastních rukou doručil zaměstnanci sám, tak může soud přihlédnout např́klad $k$ tomu, zda zaměstnanec byl vůbec (objektivné) prostředky zaméstnavatele dosažitelný, zda zaméstnavatel takový pokus učinil, co bylo důvodem př́padně neúspěšného doručení, zda mélo nějaký smysl učinit dalši pokus o doručení, jak naléhavé bylo doručení písemnosti, zda bylo možné očekávat, že doručení prostřednictvím provozovatele poštovních služeb bude úspěšnější, než opakované doručováni zaměstnavatelem apod." (viz. rozsudek Nejvyššího soudu ze dne 7. 11. 2018, sp. zn. 21 Cdo 2036/2017, ECLI:CZ:NS:2018:21.CDO.2036.2017.1.).

10 ELIÁŠ, K. Právní úkony na soukromých listinách se zvláštním zrretelem k jejich podepisování. AD NOTAM, 1996, č. 3, s. 53.

11 KRČMÁR̆, J. Právo občanské, dil V. - Právo dědické. Praha: Všehrad, 1930, s. 22.

12 Viz např. BUREŠ, J. - DRÁPAL, L. Občanský soudní řád. Komentářr. Praha: C. H. Beck, 1996, s. 61.

13 Nutno však v tomto směru podotknout, že písemná forma právního úkonu může podmiňovat platnost právního úkonu, nikoliv však jeho dokazatelnost. Dojde-li proto ke ztrátě či zničení listiny, není vyloučeno domáhat se nároků z tohoto právního úkonu. Lze-li ovšem tento právní úkon i splnění formy dokázat jinak (např. jinou listinou, svědecky, znalecky, apod.). Neexistence listiny v čase tak pouze oslabuje důkazní pozici (prokazatelnost), nikoliv však př́mo platnost. 
jový či jinak mechanicky na listině vytištěný podpis (řetězec znaků), příp. vlastnoruční podpis (např. zcela nečitelný klikyhák, resp. pouhé iniciále p), či zda je třeba uvést skutečné a úplné jméno tak, jak je zapsáno v matrice a osobních dokladech jednající osoby (tedy nejenom včetně jména a príijmení, ale také i titulů, případně bydliště, rodného čísla, apod.). Při hledání odpovědi nutno přihlédnout k účelu, resp. funkci podpisu. Nečitelnost podpisu by totiž v obecné rovině neměla mít na splnění zákonného požadavek podepsat písemné právní jednání žádný vliv. Podpis v tomto ohledu neplní primárně funkce identifikační, ale zejména stvrzovací, kde stvrzuje skutečnost, že podepisující osoba je vázána svým jednáním, a to právě od okamžiku podpisu. V tomto ohledu lze zcela jistě připustit i uvedení pseudonymu za předpokladu, že to bude známý pseudonym umožňující určení jednající osoby.

S absence právní definice podpisu se vyrovnala právní doktrína, která za podpis na soukromých listinách zpravidla považuje uvedení jména a př́jmení na konci textu právního jednání. ${ }^{14}$ I takováto pravidlo má však své výjimky (viz např. tradice podepisování advokátních písemností na první straně listin, apod.). Pro naplnění požadavku podpisu tak zpravidla postačuje uvedení pouze jména, příjmení. Obecně lze setrvat na požadavku, že je zásadě nutný podpis vlastnoruční (bez ohledu na to, zda je i celé právní jednání učiněno vlastnoručně, či např. sepsáno v textovém editoru. Nutno totiž zohlednit také další funkce podpisu, zejména pak označovací (tj. označení toho, kdo právní jednání činí), jakož i podpůrně funkci identifikační, resp. důkazní, tj. umožnění ověrit identitu podepisující osoby.

S tím ale velmi úzce souvisí i jednotlivé skupiny (kategorie) podpisu užívané v našem právním řádu. Vyjma některých (v mnoha ohledech zjevně překladových nesrovnalostí1 ${ }^{15}$ ) lze totiž ze (striktně) právního hlediska rozlišovat podpis ${ }^{16}$, vlastnoruční podpis ${ }^{17}$, ověřený podpis (at' již soudně, notářsky nebo úředně, případně advokátem) ${ }^{18}$, elektronický podpis (včetně jeho vyšších forem), další hybridní formy podpisu (biometrický podpis, apod.).

\section{PODPIS ELEKTRONICKÝCH PÍSEMNOSTÍ (PRÁVNÍCH JEDNÁNÍ)}

Zákoník práce obsahuje zvláštní právní úpravu právních jednání v ustanovení § 18-20; nejde však o úpravu komplexní, a tedy se subsidiárně použije občanský

14 LAVICKÝ, P. a kol. Občanský zákonik I. Obecná část (§ 1-654). Komentář. 1. vyd. Praha: C. H. Beck, 2014, s. 2022.

15 Jde zejména o pojmy „vlastní podpis“, „podpis vlastní rukou“ (např. čl. 3 odst. 1 sdělení č. 179/1996 Sb.), které považuji s ohledem na dikci jednotlivých ustanovení za synonymické pojmu „vlastnoruční podpis“. Dále s ohledem na § 74 zákona č. 358/1992 Sb. za variantu podpisu nepovažuji „podpis na listině, který osoba uznala za vlastní“ či jiné jeho obdoby. Ověřením podpisu totiž podpis, resp. jeho listina ztrácí část svého jinak ryze soukromoprávního charakteru, přičemž pak plní jiný účel, resp. funkci.

16 Pojem „podpis“ se dle informačního systému Codexis (bez dalších adjektiv) vyskytuje v našem právním rrádu ve více jak 1500 dokumentech v počtu větším než 4500 výrazů (z toho však více jak 1000 výrazů se nachází ve necelých 300 zákonných předpisech).

17 Pojem „vlastnoruční podpis“ již bývá zákonodárcem výslovně užíván velmi zř́́dka. Lze hovořit pouze o několika desítkách výrazů.

18 Viz např. zákon č. 358/1992 Sb., o notářích a jejich činnosti (dále jen notářský řád), v platném znění. 
zákoník, který je tradičně postaven tradičně na relativně neměnných právních principech stanovících určité mantinely, jež jsou ve svém důsledku omezující jak samotného zákonodárce, tak i pro př́ípustný interpretačně-aplikační rozsah právní úpravy. Mezi takovéto principy bezesporu patří zásada dispozitity právní úpravy a princip právní jistoty, včetně na tuto zásadu navazujících postulátů jako je zákaz retroaktivity, ochrana nabytých práv, předvídatelnost rozhodování apod. Oba tyto principy jsou důsledně reflektovány v ustanovení § 559-564 občanského zákoníku upravující formy právního jednání, a to včetně tzv. elektronických právních jednání jako specifických písemností realizovaných elektronickými prostředky, včetně požadavku na jejich podpis.

Právní jednání může mít v zásadě libovolnou formu, není-li zákonem vyžadována forma písemná (§ 559 občanského zákoníku an.), a to zpravidla tam, kde to vyžaduje jeho význam a povaha. V tomto ohledu tak lze rozlišovat právní jednání neformální, jejichž formu zákon neupravuje, a právní jednání formální, tj. ta, pro která je zákonem předepsána určitá (zpravidla písemná) forma, jež tak současně plní určitou varující funkci. Nedodržení takto stanovené formy může mít za následek relativní ${ }^{19} \mathrm{i}$ absolutní ${ }^{20}$ neplatnost právního jednání ${ }^{21}$, nikoliv však ve všech př́padech; soudní praxe následky neplatnosti omezuje zpravidla na případy, pokud to smysl a účel zákona vyžaduje (NS 29 Cdo 3919/2014).

Je-li zákonem vyžadována písemná forma ${ }^{22}$, stanoví dále zákon, že k platnosti takového jednání ( $\mathrm{tj}$. učiněného v písemné formě) se vyžaduje podpis jednajícího, přičemž dále blanketovou právní normou odkazuje na jiný právní předpis, který stanoví, jak lze při právním jednání učiněném elektronickými prostředky písemnost elektronicky podepsat (§ 561 odst. 1občanského zákoníku). Takovýmto právním předpisem je především ZoSVD, který je tzv. adaptačním předpisem k nařízení eIDAS. V př́ípadě elektronických právních jednání tak je požadavek písemné formy naplněn tak, že k obsahu tohoto jednání bude připojen elektronický podpis ve smyslu ZoSVD.

Platná právní úprava však připouští i výjimku z výše uvedeného pravidla o požadavku podpisu písemného právního jednání. Z ustanovení § 562 odst. 2 občanského

19 Zejména pak v situacích, kdy je zákonný požadavek na právní formu stanoven pouze na ochranu zájmu určité osoby, tj. plní v zásadě pouze varující funkci pro účastníky takovéhoto jednání (§ 586 občanského zákoníku).

20 Zejména pak v situacích, kde se zvolená forma jeví jako př́íćíí se dobrým mravům, anebo které odporuje zákonu a zjevně narušuje veřejný pořádek (§ 588 občanského zákoníku). Absolutní neplatnost tak bude namístě zejména tehdy, kdy požadavek formy neplní pouze funkci varující, ale zejména zajištovací ve prospěch třetích stran nebo ve veřejném zájmu - viz např. převod věcného práva k nemovité věci dle $\S 560$ občanského zákoníku), apod.

21 Hovoříme tak o náležitosti právního jednání ve smyslu ustanovení $§ 545$ občanského zákoníku. Předepsaná forma by měla být $\mathrm{v}$ zásadě dodržena $\mathrm{k}$ celému právnímu jednání, judikatura nicméně nevylučuje, aby části právního jednání byly učiněny v různých formách. K tomu srovnej rozhodnutí NS 29 Odo 14/2001, prípadně NS 2 Odon 76/97.

22 Povinnost písemné formy může být uložena zákonem, nebo předchozí vzájemnou dohodou stran (§559 o. z.). Bez jejího uložení lze jednat elektronicky jakýmkoli způsobem, i bez elektronického podpisu vůbec. K volbě formy nelze nikoho nutit, a to ani k jejímu přijímání (opět § 559 o. z.). Právním jednáním učiněným elektronickými prostředky zatím nelze podle práva ČR provést jednání, která u vlastnoručního podpisu vyžadují ověření podpisu třetí stranou (úřední ověření). Nelze jím provést ani taková právní jednání, u kterých zákon stanoví více náležitostí než jen písemnou formu, např. požadavek napsání závěti vlastní rukou podle §1533občanského zákoníku. K tomu více KMENT, V. Nahradí elektronický podpis prostý ten tradiční vlastnoruční? In: Bulletin advokacie. Roč. 2016, č. 12, s. 5. 
zákoníku vyplývá, že písemná forma je zachována u právních jednání učiněných elektronickými nebo jinými technickými prostředky, jež umožňují zachycení jeho obsahu a určení jednající osoby, a to zcela bez ohledu, zda byly podepsány či nikoliv. Jde tak o zvláštní úpravu elektronické písemnosti bez podpisu (lex specialis ${ }^{23}$ ve vztahu k § 561 odst. 1 občanského zákoníku), které zákon přiznává právní účinky písemnosti za předpokladu, že jde o písemnost způsobilou zachytit obsah tohoto jednání a určit, resp. identifikovat jednající osobu. ${ }^{24}$ Zákon tak sice výslovně podpis pro tyto jiné formy nestanoví, nicméně stanoví v zásadě obdobný požadavek identifikace jednající osoby, což lze považovat za svého druhu zákonnou alternativu podpisu, jehož účelem i hlavní funkcí je zpravidla právě identifikace; $v$ tomto ohledu tak lze soudit, že tento požadavek „identifikace“ může být naplněn např. nějakým biometrickým či jiným obdobným identifikátorem, který sice stricto sensu nepředstavuje podpis v právním smyslu, nicméně plní zpravidla obdobný účel i funkci. Uvedené pojetí tak reflektuje jak autonomii vůle stran v soukromém právu, tak zároveň i představuje krok směrem k rozšiřování elektronické kontraktace i právního styku. ${ }^{25}$

Jak již bylo zmíněno výše, pro elektronická právní jednání stanoví občanský zákoník podmínku připojení elektronického podpisu ve smyslu ZoSVD, který představuje jediný právní předpis, který stanoví, jak lze takovouto písemnost podepsat. Ustanovení $\S 5$ a násl. ZoSVD pak upravuje druhy podepisování v závislosti na podepisujícím subjektu, resp. jeho veřejnoprávní povaze, jakož i jednotlivé právně př́pustné druhy elektronického podpisu upravené v eIDAS. Z $\$ 7$ tohoto zákona pak jednoznačně vyplývá, že $\mathrm{k}$,podepisování elektronickým podpisem lze použit zaručený elektronický podpis, uznávaný elektronický podpis, př́padně jiný typ ${ }^{26}$ elektronického podpisu, podepisuje-li se elektronický dokument, kterým se právně jedná jiným způsobem než způsobem uvedeným v § 5 nebo § 6 odst. 1.“. Za tzv. ,jiný typ elektronického podpisu“ ve smyslu tohoto ustanovení nutno považovat i základní (prostý) elektronický podpis dle eIDAS, prričemž ,jiným způsobem“ je pak právě právní jednání ve smyslu občanského zákoníku, tj. typicky podepisování soukromých elektronických písemnosti. Z platné právní

23 K obdobnému závěru dochází též komentářová literatura MELZER, F. - TÉGL, P. a kol. Občanský zákonik - velký komentár̆. Svazek III., s. 637, případně i ŠVESTKA a kol., s. 1387, př́ípadně též PETROV, VYTISK a kol., s. 597.

24 Jako problematické se v tomto smyslu nicméně jeví ustanovení § 3026 odst. 1občanského zákoníku, které stanoví, že nevylučuje-li to povaha písemnosti, platí ustanovení tohoto zákona o listině obdobně i pro jinou písemnost bez zřetele na její podobu. Uvedené ustanovené tak výslovně připouští použití analogie těch zákonných ustanovení upravujících formu listiny i pro jiné formy písemností, tedy včetně písemností elektronických i jiných textů nepřenositelných na hmotných nosičích, apod. Vzniká tak otázka, zda i na pro formy elektronické písemnosti bez podpisu ve smyslu ustanovení § 561 odst. 1občanského zákoníku nepožadovat podpis (per analogiam).

25 V souvislosti s výše uvedeným nutno zmínit i navazující ustanovení § 562 odst. 2občanského zákoníku upravující tzv. domněnku spolehlivosti elektronických záznamů stanovící, že záznamy údajů o právních jednáních v elektronickém systému jsou spolehlivé, provádějí-li se systematicky a posloupně a jsou-li chráněny proti změnám. Byl-li záznam pořízen při provozu závodu a dovolá-li se jej druhá strana k svému prospěchu, má se za to, že záznam je spolehlivý.

${ }^{26}$ Za výjimky v tomto smyslu zákon považuje pouze jednání státu, resp. jeho organizačních složek a dalších veřejnoprávních podepisujících podle $\S 5$ odst. 1 ZoSVD, jež vyžaduje kvalifikovaný elektronický podpis ve smyslu eIDAS. 
úpravy tak vyplývá, že v soukromoprávních vztazích postačit pro splnění formálních náležitostí v zásadě jakýkoliv typ elektronického podpisu dle eIDAS.

Nahlédneme-li do př́islušných ustanovení eIDAS, zjistíme, že základní forma elektronického podpisu je vymezena v ustanovení čl. 3 odst. 10, který stanoví, že elektronickým podpisem jsou:

- data v elektronické podobé,

- která jsou připojena k jiným datům v elektronické podobě nebo jsou s nimi logicky spojena a

- která podepisující osoba použivá k podepsání.

Prostou analýzou výše uvedeného vymezení lze dojít k závěru, že předmětné vymezující ustanovení neobsahuje samo o sobě jakékoliv kvalitativní požadavky směrem k identifikaci či určení totožnosti podepisující osoby. V zásadě jedinou kvalitativní náležitostí je vysoce obecný odkaz na svého druhu zvyklost podepisující osoby připojit „data užívaná $k$ podepsáni“, což mohou být v zásadě jakákoliv data v elektronické podobě. Podrobněji, byt' s odlišnou právní kvalifikací, se problematikou elektronické kontraktace, jakož i jednotlivým náležitostem a funkcím věnovali např. J. Matejka ${ }^{27}$, R. Polčák ${ }^{28}$, F. Korbel s F. Melzerem ${ }^{29}$, K. Čermák ${ }^{30}$, posledně též V. Kment ${ }^{31}$.

\section{DŮKAZNÍ SPOLEHLIVOST PODPISU NA SOUKROMÝCH LISTINÁCH - PRESUMPCE SPOLEHLIVOSTI ZÁZNAMŮ O PRÁVNÍCH JEDNÁNÍCH OBSAŽENÝCH V ELEKTRONICKÉM SYSTÉMU}

S podmínkou písemnosti a písemného projevu vůle pracuje i ustálená česká judikatura ${ }^{32}$, obdobně je v právní praxi pamatováno také dokazování pravosti těchto listin, kde se důsledně vychází z toho, že je na každém, kdo se dovolává soukromé listiny, aby dokázal její pravost a správnost. Je-li soukromá listina použita proti osobě, která listinu zjevně podepsala, nebo proti jejímu dědici nebo proti tomu, kdo nabyl jmění při přeměně právnické osoby jako její právní nástupce, má se za to, že pravost a správnost listiny byla uznána ( $\$ 565$ občanského zákoníku). Z hlediska důkazně procesního tak lze všechny formy elektronických písemností (včetně jejich podpisu) považovat za rovnocenné, resp. ekvivalentní (viz výše), a mohou tedy sloužit jako důkaz ve smyslu všech procesních předpisů českého práva; právní úprava ale obsahuje poměrně netriviální proceduru upravující důkazní spolehlivost některých souvisejících důkazů, a to zejména

27 MATEJKA, J. Úprava elektronického podpisu v právním řádu ČR, Právník, 2001, 4. 5, s. 582-611.

28 POLČÁK, R. Elektronické právní jednání - změny, problémy a nové možnosti v zákoně č. 89/2012 Sb., Bulletin advokacie, 2013, 4. 10, s. 34-40, s. 36, případně též POLČÁK, R. Praxe elektronických dokumentů, Bulletin advokacie, 2011, č. 7-8, s. 55.

29 KORBEL, F. - MELZER, F. Písemnost, elektronický a biometrický podpis v elektronickém právním jednání, Bulletin advokacie, 2014, č. 12, s. 31-6, s. 32.

30 ČERMÁK, K. ml. Elektronický podpis: pohled soukromoprávní. Bulletin advokacie č. 11/2002, s. 64-77.

31 KMENT, V. Nahradí elektronický podpis prostý ten tradiční vlastnoruční? In: Bulletin advokacie, 2016, č. 12, s. 5 .

32 Viz např. Rozsudek Nejvyššího soudu sp. zn. 30 Cdo 1230/2007. 
v ustanovení $§ 565^{33}$ a 566 občanského zákoníku³, kde zákonodárce poněkud nadbytečně hovoří výslovně o pojmu ,soukromá listina“, nikoliv tedy „,soukromá písemnost“, avšak s ohledem na závěry právní doktríny ${ }^{35}$ i ustanovení $§ 3026$ odst. 1 občanského zákoníku ${ }^{36}$, lze dospět k závěru, že se toto ustanovení vztahuje i na soukromé (elektronické) písemnosti.

Z jiného hlediska však lze za klíčové z pohledu důkazní spolehlivosti považovat především ustanovení $§ 562$ odst. 2 větu druhou občanského zákoníku ${ }^{37}$, obsahující jasnou presumpci důkazní spolehlivosti (vyvratitelnou právní domněnku), která reflektuje moderní přístupy k podstatě elektronických písemností a zároveň výrazně usnadňuje užití obvyklých a stále více se vyskytujících forem elektronické kontraktace ${ }^{38}$. Tato cesta zvolená českým zákonodárcem je v mnoha ohledech vhodnější než spoléhat na různé pokusy směřující k zabránění známé erozi důkazní spolehlivosti elektronických písemností tím, že k dokumentu připojujeme další a další autentizační mechanismy (typicky napřr. další kvalifikované podpisy, značka a razítka. Trend elektronického zpracování dokumentů však jednoznačně směřuje k založení jejich důkazní spolehlivosti nikoli prostřednictvím individuálního elektronického podpisu dokumentu, ale prostřednictvím kvalifikované metody a postupu, kterým byl dokument vytvořen nebo kterým je dlouhodobě uložen ${ }^{39}$. Je to tedy elektronický systém, resp. jeho funkční vlastnosti, architektura a design, jež poskytují garance, prostřednictvím nichž presumujeme či následně prokazujeme pravost či autenticitu tam zpracovaných elektronických písemností. Prokáže-li ten, kdo písemností argumentuje, že systém, v němž se písemnost nachází, tyto parametry má, přesouvá se důkazní břemeno na toho, kdo tvrdí nedostatek její pravosti.

Elektronické písemnosti tak mají z hlediska svého významu, možností použití i samotné právní síly, v zásadě ekvivalentní postavení jako jiné tradiční formy, včetně forem listinných (typicky papírových nosičů záznamu) ${ }^{40}$. Tato ekvivalence listinné

33 Je na každém, kdo se dovolává soukromé listiny, aby dokázal její pravost a správnost. Je-li soukromá listina použita proti osobě, která listinu zjevně podepsala, nebo proti jejímu dědici nebo proti tomu, kdo nabyl jmění při přeměně právnické osoby jako její právní nástupce, má se za to, že pravost a správnost listiny byla uznána.

34 (1) Není-li soukromá listina podepsána, je na tom, kdo ji použil, aby dokázal, že pochází od osoby, o níž to tvrdí. (2) Má se za to, že písemnosti týkající se právních skutečností, k nimž dochází při běžném provozu závodu, dokazují, dovolává-li se jich druhá strana k svému prospěchu, co je v listině obsaženo a že listina byla vystavena v době na ní uvedené; to platí i v př́ípadě, že listina nebyla podepsána.

35 Viz např. MATEJKA, J. Úprava elektronického podpisu v právním řádu ČR, Právník, 2001, č. 5, s. $582-611$.

36 Nevylučuje-li to povaha písemnosti, platí ustanovení tohoto zákona o listině obdobně i pro jinou písemnost bez zřetele na její podobu.

37 Má se za to, že záznamy údajů o právních jednáních v elektronickém systému jsou spolehlivé, provádějí-li se systematicky a posloupně a jsou-li chráněny proti změnám. Byl-li záznam pořízen při provozu závodu a dovolá-li se jej druhá strana k svému prospěchu, má se za to, že záznam je spolehlivý.

$38 \mathrm{~K}$ tomu vice viz např. MASON, S. Electronic Signatures in Law. Cambridge University Press, Cambridge, 2012, s. 259.

$39 \mathrm{~K}$ tomu více viz POLČÁK, R. Elektronické právní jednání: změny, problémy a nové možnosti v zákoně č. 89/2012 Sb. Bulletin advokacie, 2013, č. 10, s., 34 40. Dostupný také na: <http://www.bulletin-advokacie .cz/elektronicke-pravni-jednani-zmeny-problemy-a-nove-moznosti-v-zakone-c.-892012-sb>, případně též VOLAREVIC, M. - STRASBERGER, V. - PACELAT, E. A philosophy of the electronic document management, in Information Technology Interfaces. Pula: IEEE, s. 141.

40 Uveden princip tak nepřímo akcentuje mimo jiné ustanovení § 2 písm. e) zákona č. 499/2004 Sb., o archivnictví a spisové službě, podle nějž se dokumentem rozumí každá písemná, obrazová, zvuková nebo jiná zaznamenaná informace, at' již v podobě analogové či digitální. 
a elektronické formy tak má v mnoha ohledech výrazně širší dopady, než jen na písemnosti, nebot' se po právní stránce týká nejen písma, ale i obrazu, zvuku či jiných záznamů; limitem tak zde nebudou právní omezení jejich použitelnosti, ale především existující technické možnosti záznamu na papír. ${ }^{41}$

\section{BEHAVIORÁLNÍ FORMY - BIOMETRICKÝ PODPIS}

S ohledem na použitou technologii lze hovořit o celém spektru dalších možných variant elektronického podepisování. Obvykle ale půjde o odvozeniny podpisů elektronických, přičemž odlišujícím kritériem bude obvykle způsob použitého autentizačního mechanismu (vzorku), př́ípadně míra kvality zabezpečení, použité technologie, př́ípadně záruk třetích stran (typicky certifikačních autorit).

Právě z pohledu použitých autentizačních, resp. identifikačních mechanismů je vhodné uvést zejména široké možnosti autentizace prostřednictvím behaviorální biometrických znaků člověka (např. dynamiky záznamu řeči, chůze, psaní na klávesnici, apod.). Typickým projevem tohoto př́stupu představuje tzv. dynamický biometrický podpis, který činí podpisující osoba vlastní rukou, avšak nikoli na listinu, nýbrž na vysoce citlivé zařizení (tablet), které digitálně zaznamenává nejen konkrétní podobu samotného (vlastnoručního) podpisu, ale i celou řadu další údajů, včetně tvaru opsané křivky, dynamiku polohy pera, celkové i etapové rychlosti, fragmentového zrychlení, přítlaku po celou dobu vedení pera, apod. Kombinace všech uvedených charakteristik v rámci dynamického biometrického podpisu je pak natolik unikátní a specifická pro konkrétní osobu, že ji může s dostatečnou přesností identifikovat, přičemž z tohoto důvodu představuje vysoce atraktivní formu autentizace. ${ }^{42}$ Tyto údaje (charakteristiky) jsou v závislosti na použité technologii zaznamenány do digitálního souboru (datové zprávy), který z pohledu platné právní úpravy splňuje náležitosti (prostého) elektronického podpisu.

Uvedené ustanovení je klíčové z hlediska samotné důkazní spolehlivosti moderních forem podpisu, a to včetně tzv. dynamického biometrického podpisu (viz výše). Vezmeme-li v úvahu, že tato technologie podpisu v nějaké své fázi musí shromažd'ovat biometrické charakteristiky podepisující se osoby (lhostejno zda oprávněně s jejím vědomím, př́ípadně neoprávněně pod nepravdivou záminkou), nelze vyloučit, že tato data mohou být v budoucnosti zneužita pro vytvoření dalších odvozenin původního podpisu.

41 Ani občanského zákoníku tak v zásadě zásadně nepreferuje výrazně listinu před jinými formami písemností, např. dle $\S 3026$ odst. 1 platí všechna ustanovení zákoníku o listinách i pro jiné písemnosti bez zřetele na jejich podobu (formu), to však jen za předpokladu, že to nevylučuje povaha písemnosti. Povaha písemnosti to např. bude vylučovat u holografních listin, kde se vyžaduje, aby byla skutečně ručním písmem napsána jednajícím, nikoli vytvořená prostředky ICT.

Viz např. tradiční požadavek vlastnoručního podpisu u závěti v § 1533 nebo obdobný, ale zcela zbytečný požadavek u hlasování vlastníků jednotek při rozhodnutí shromáždění vlastníků jednotek mimo zasedání dle $\S 1212$ ).

42 Nutno však pro úplnost uvést, že ačkoliv právě z těchto důvodů tento druh podpisu zavádí do praxe celá řada osob, včetně typu bank, mobilních operátorů, přepravců atd., ze strany podepisující osoby nejde o vlastnoruční podepisování v právním slova smyslu, ale pouze o formu autentizace vázané na odběr konkrétní dynamické charakteristicky konkrétní osoby. 
Biometrické podpisy totiž existují „samy o sobě“a nezávisí na podepsaném dokumentu. V principu tedy nelze vyloučit, aby byly z původních elektronických písemností odňaty a připojeny $\mathrm{k}$ jiným písemnostem. ${ }^{43}$

Pro praktické využití biometrických podpisů k podepisování elektronických dokumentů proto potřebujeme nějakou „dostatečně spolehlivou a pevnou“ vazbu mezi samotným podpisem a dokumentem. Takovou, kterou by nešlo zpřetrhat, a která okamžitě odhalí jakoukoli manipulaci (změnu dokumentu či samotného podpisu). Tyto postupy jsou však s ohledem na rozvoj neuronových sítí (umělé inteligence) stále více netriviální; lze však jít cestou jejich propojení s metodami asymetrické kryptografie (viz níže), kde se k podepisovanému dokumentu připojí získaná biometrická data (dynamický biometrický podpis), a výsledný podpis následně systém podepíše svým kvalifikovaným elektronickým podpisem. ${ }^{44}$

Právě tyto skutečnost představuje patrně zásadní nevýhodu výrazně limitující či alespoň omezující další rozvoje a použití této (behaviorální) kategorie podpisu, a to včetně pracovněprávních vztahů, kde lze ochranu souvisejících osobních údajů považovat za zásadní atribut realizace těchto vztahů. ${ }^{45}$

\section{DORUČOVÁNÍ PROSTŘEDNICTVÍM INFORMAČNÍHO SYSTÉMU DATOVÝCH SCHRÁNEK}

Informační systém datových schránek (ISDS) představuje zvláštní systém elektronického úložišstě určeného k doručování elektronických dokumentů od orgánů veřejné moci a k provádění úkonů vůči orgánům veřejné moci a dodávání dokumentů fyzických i právnických osob mezi sebou. Tento systém byl založen zákonem č. 300/2008 Sb., o elektronických úkonech a autorizované konverzi dokumentů (ZoSVD), jež nabyl účinnosti dne 1. července 2009. Tento zákon svou koncepcí narušuje a zásadně mění dosavadní způsoby činností orgánů veřejné moci př̀i uskutečňování písemných právních úkonů. Tímto nastává faktické přerušení zažitých mnohdy více jak sto let trvajících principů, metod „listinného“ fungování české veřejné správy, jejíž kořeny a historie sahají do první poloviny 18 . století. Zákon tak lze označit za určitý právní milník 21. století, století, ve kterém dochází k jednotné „elektronizaci“ orgánů

43 Viz. MATEJKA, J. - GÜTTLER, V. Electronic Written Documents and Biometric Options of Their Signing - Problem of Evidentiary Reliability and Personal Data Protection. In: The Lawyer Quarterly, 2018, roč. 8 , č. 1 , s. $38-50$.

44 Uvedená procedura však klade velmi vysoké nároky na kvalitu a funkční vlastnosti př́ílušných systémů, navíc zde přibývá nutností sofistikovaného vyhodnocení biometrických údajů (vůči podpisovému vzoru), a tedy i dalšího potenciálního ohrožení celého systému (možnost zneužití databáze podpisových vzorů), apod. Tyto aspekty však nebyly dosud uspokojivě řešeny. K tomu více viz PETERKA, J. Elektronický podpis na rozcestí. [online] [cit. 28. 12. 2011]. Dostupné na: <http://www.lupa.cz/clanky/elektronicky-podpis-na-rozcesti>.

$45 \mathrm{~K}$ tomu více viz $\mathrm{K}$ problematice lidských práv se zřetelem $\mathrm{k}$ biometrice více viz GÜTTLER, $\mathrm{V}$. MATEJKA, J. K otázkám některých základních lidských práv a svobod v souvislosti s právní ochranou biometrických údajů. Právník, 2016, roč. 155, č. 12, s. 1055, dále též viz MATEJKA, J. - GÜTTLER, V. Electronic Written Documents and Biometric Options of Their Signing - Problem of Evidentiary Reliability and Personal Data Protection. In: The Lawyer Quarterly, 2018, roč. 8, č. 1, s. 38. 
veřejné moci ČR. Zákon tak ve svém důsledku představuje jeden z nejvýznamnějších předpisů regulujících právní vztahy v prostředí české informační společnosti. Nutno pro úplnost uvést, že ČR je v podstatě prvním státem na světě, kde je používání datové schránky pro orgány veřejné moci a podnikající subjekty v režimu zákona obligatorní. V Evropě obdobný informační systém funguje např́íklad v Dánsku a Rakousku, v Německu je podobný systém připravován. Evropská unie zatím takovýto komunikační kanál nemá, ale $\mathrm{v}$ budoucnu jistě bude podobný komunikační nástroj potřebovat ${ }^{46}$. Za hranicemi Evropského kontinentu, konkrétně ve Spojených státech amerických, je obdobný systém využíván v Kalifornii pro komunikaci mezi veřejnou správou a velkými korporacemi ${ }^{47}$.

Datová schránka je podle $\S 2$ zákona elektronickým úložištěm, které je určeno k dvěma účelům a to: a) doručování orgány veřejné moci, b) provádění úkonů vůči orgánům veřejné moci. Dne 1. 1. 2010 přibyl i třetí účel, a to dodávání dokumentů fyzických osob, podnikajících fyzických osob a právnických osob. Samotná elektronická komunikace pomocí datové schránky je realizována prostřednictvím tzv. datové zprávy, která představuje elektronická data, jež lze přenášet prostředky pro elektronickou komunikaci a uchovávat je na záznamových médiích používaných při zpracování a přenosu dat elektronickou formou ${ }^{48}$. Datovou zprávu tvoří obálka a obsah zprávy, přičemž obsahem zprávy může být jedna či více př́loh v povoleném datovém formátu. Dokument, který byl dodán ${ }^{49}$ resp. odeslán do datové schránky, je doručen okamžikem, kdy se do datové schránky přihlásí osoba, která má s ohledem na rozsah svého oprávnění přístup $\mathrm{k}$ dodanému resp. doručenému dokumentu. Takovouto osobou bude zejména primární uživatel datové schránky tj. osoba, které byla datová schránka zřízena anebo též i soba pověřená či administrátor. Je důležité upozornit, že doručení dokumentu zmíněným způsobem má stejné právní účinky jako doručení do vlastních rukou. ${ }^{50}$

Ustanovení § 18 odst. 2 ZoSVD pak obsahuje zvláštní úpravu podpisu, resp. přesněji jeho domněnky; zákon zde stanoví, že úkony učiněné primárním uživatelem datové schránky, tzn. úkony jako podání, návrhy, podněty, žádosti, atp., př́ípadně též administrátorem anebo pověřenou osobou, mají stejné účinky jako úkony učiněné písemně a podepsané, ledaže jiný právní předpis nebo vnitřní předpis požaduje společný úkon více z uvedených osob. ${ }^{51}$

46 IDNES.Cz. On-line rozhovor. Chýlek, P., a Stiegler, P., [online] [cit. 19. 11. 2009].

47 Loebl., Z. Datové schránky v justici? Nevěřím, že budou v praxi fungovat. [cit. 18. 8. 2009] Dostupné online na: $<$ http://www.ejustice.cz/zbynek-loebl-datove-schranky-v-justici-neverim-ze-budou-v-praxi -fungovat $>$.

48 K tomu srovnej definici elektronického podpisu uvedenou v § 2 zákona č. 227/2000 Sb., o elektronickém podpisu, v platném znění.

49 Zákon přitom volí slovo „dodán“ namísto „doručen“ či „,zaslán“.

50 Na doručování dokumentů mezi orgány veřejné moci prostřednictvím datové schránky se vztahují dvě omezení. Prvním omezení vyplývá z předmětu zákonné úpravy, kde je stanoveno, že Zákon se nevztahuje na dokumenty, které obsahují utajované informace. Druhým omezením jsou důvody bezpečnostního charakteru, nebot' doručování mezi orgány veřejné moci prostřednictvím datové schránky se nepoužije, pokud je z bezpečnostních důvodů mezi těmito orgány zavedena jiná forma elektronické komunikace.

51 Obecně však není dána povinnost jednající osoby resp. osoby činící úkon prostř̌ednictvím datové schránky použivat zaručený elektronický podpis. 


\section{ZÁVĚR}

Jak bylo stanoveno v úvodu tohoto článku, současná pracovněprávní úprava realizace významných pracovněprávních úkonů (ve smyslu § 334 odst. 2 zákoníku práce) nepočitá díky zvláštní úpravě jejich doručování a své relativní komplexnosti s tím, že by elektronické pracovněprávní písemnosti mohly být doručovány (či přesněji realizovány) i jiným způsobem než výhradně jen prostřednictvím služby či sítě elektronických komunikací. $Z$ důvodu ochrany slabší strany kontraktačního procesu (zaměstnance) tak př́mo nepočítá s možností tzv. osobního doručení elektronické písemnosti např. formou jejího osobního předání, případně s jinými variantami, které jsou s ohledem na svou podstatu důkazně spolehlivější než je tradiční forma doručování listinných písemností v podobě tzv. předání „,Z ruky do ruky“, případně nesrovnatelně spolehlivější z pohledu výsledného stvrzení těchto úkonů tradičním vlastnoručním podpisem obou smluvních stran.

Jde zejména o standardní možnosti realizace těchto pracovněprávních jednání formou elektronického podpisu dle eIDAS, resp. jeho vyšší (uznávaných) variant, př́ípadně elektronických variant podpisů založených na biometrické (behaviorální) autentizaci podepisující osoby, kde lze současné zákonné požadavky kladené na jejich doručování považovat za nepřiléhavé a v zásadě i ohrožující všechny moderní formy elektronického právního styku. Pracovněprávní úprava tak rovněž nereflektuje související možnosti vyplývající ze shora uvedené domněnky spolehlivosti elektronických záznamů stanovící, že záznamy údajů o právních jednáních v elektronickém systému jsou spolehlivé, provádějí-li se systematicky a posloupně a jsou-li chráněny proti změnám (§562 odst. 2 občanského zákoníku). Lze jistě namítnout, že současná právní úprava výslovně nevylučuje řešit uvedené určitou odchylnou úpravou ve smyslu ustanovení § 4a zákoníku práce, případně formou systematického extensivního výkladu pojmu „do vlastních rukou“ či jinou formou argumentace „e ratione legis“, př́ípadně pomocí výkladových pravidel upravených v občanském zákoníku ${ }^{52}$; výsledek takové interpretace by však s ohledem na jeho následnou aplikaci nemusel v současnosti poskytovat dostatečnou míru právní jistoty.

Navzdory relativně rigidní a omezující podobě současného pracovního práva však nutno připomenout, že je zde minimálně velmi sporně naplňován princip obsažený v čl. 25 odst. 1 prrímo použitelného nařízení eIDAS, podle kterého nesmějí být elektronickému podpisu upírány právní účinky a nesmí být odmítán jako důkaz v soudním a správním ř́zzení pouze z toho důvodu, že má elektronickou podobu nebo že nesplňuje

\footnotetext{
$52 \mathrm{~K}$ tomu např. srovnej ustanovení $\S 2$ odst. 1 občanského zákoníku „Každé ustanovení soukromého práva lze vykládat jenom ve shoděs Listinou základnich práv a svobod a ústavním pořádkem vi̊bec, se zásadami, na nichž spočivá tento zákon, jakož is trvalým zřetelem k hodnotám, které se tím chrání. Rozejde-li se výklad jednotlivého ustanovení pouze podle jeho slov s tímto př́kazem, musi mu ustoupit.“, prípadně též výkladové pravidlo upravené v ustanovení § 20 zákoníku práce „Je-li možné právní jednání vyložit ruozným zpưsobem, použije se výklad pro zamèstnance nejpřiznivějšsi. “"
} 
požadavky na kvalifikované53 elektronické podpisy ${ }^{54}$; lze jistě souhlasit s tezí, že jedním z účelů zákonem požadované písemné formy, resp. naplnění souvisejících požadavků na jejich doručování, je mimo jiné55 určitá varující funkce, případně s ohledem na význam konkrétního jednání také funkce důkazní, což však vhodná varianta podpisu dle eIDAS splňuje.

Všechny shora uvedené skutečnosti nutno zejména zohlednit při použití všech moderních prvků kontraktace, kde musí být dostatečně akcentována především skutečnost, že moderní pracovní právo nemůže rezignovat na své ochranné působení; je tedy třeba hledat vždy taková řešení, která zohlední jak potřebu užívání moderních kontraktačních nástrojů, tak i nutnost garantovat minimální ochranu slabší strany pracovněprávního vztahu.

Má-li být kontraktace prostřednictvím těchto moderních forem efektivní, je třeba při jejich aplikaci důsledně vycházet $\mathrm{z}$ historicky osvědčených a ustálených zásad a principů soukromého práva, včetně zvyklostí práva pracovního. Samotné elektronické formy podepisování ve formě připojení biometrických (fyzických či behaviorálních) dat k elektronickým písemnostem (právním jednáním), tak nejenom že důsledně navazují na toto tradiční (tj. především grafické) pojetí podpisu, ale zároveň představují zdánlivě ideální propojení tradičního a elektronického pojetí podepisování směřující $\mathrm{k}$ tolik žádoucímu přirozenému rozvoji práva. Připuštění možnosti užití těchto moderních forem podpisu tak v mnoha ohledech posiluje jak postavení elektronických písemností a jejich využití v právním styku, tak i zcela nepochybně povede ke standardizaci nových praktických postupu kombinujících metody biometrické (jako ideální autentizační či kvasi-identifikační nástroj) a kryptologické (kvalifikovaný elektronický podpis). Lze však přistoupit pouze $\mathrm{k}$ takovým změnám, které budou ve svých celkových souvislostech představovat úpravu komplexní, tedy úpravu, jež nebude nedůvodně diskriminovat osvědčené nástroje elektronické kontraktace a zároveň bude respektovat jak ochrannou, tak i organizační funkci pracovního práva, nebot' jen splnění všech těchto podmínek může garantovat vyváženou, stabilní a především moderní právní úpravu.

JUDr. Ján Matejka, Ph.D.

Ústav státu a práva AV ČR, v. v. i.

matejka@ilaw.cas.cz

53 Kvalifikovaný elektronický podpis má právní účinek rovnocenný vlastnoručnímu podpisu (čl. 25 odst. 2 nařízení eIDAS).

54 Rovněž i z odůvodnění nařízení eIDAS (čl. 48 a násl.) stanoví, že k zajištění vzájemného uznávání elektronických podpisů je sice zapotřebí vysoká úroveň bezpečnosti, nicméně měly by být ve zvláštních př́ípadech, napríklad v kontextu rozhodnutí Komise 2009/767/ES 10), přijímány rovněž elektronické podpisy s nižší zárukou bezpečnosti.

55 Jen výjimečně jsou plněny i další funkce, např. zajištění právní jistoty třetích stran ve formě dispozice s věcnými právy $\mathrm{k}$ nemovité věci dle $§ 560$, apod. 



\title{
ZÁVISLÁ PRÁCE A JEJÍ PRÁVNÍ REGULACE NA POČÁTKU 21. STOLETÍ - VÝZVY A PERSPEKTIVY
}

\author{
JAKUB MORÁVEK*
}

\begin{abstract}
Dependent work and its legal regulation at the beginning of the 21st century challenges and perspectives

The paper is focused on some problematic aspects of labor law legislation. The author critically evaluates legal regulation and legislative proposals regulation of working hours, leave, termination of employment etc. The author also presents possible solutions. His reflextions is also based on an international comparison.
\end{abstract}

Keywords: labor law; working time; employment termination; leave; labor union

Klíčová slova: pracovní právo; pracovní doba; skončení pracovního poměru; odborové organizace; dovolená

DOI: $10.14712 / 23366478.2019 .6$

Opakovaně jsem poukazoval na to, že společné působení moderních technologií, životní úrovně západní civilizace a aktuálního životního stylu, stávající možnosti pracovního i volnočasového vyžití, hospodářské a sociální možnosti, krátce řečeno, vše, co můžeme souhrnně označit jako projevy moderní doby, působí postupnou erozi a rozpad některých tradičních společenských institutů a institucí, $\mathrm{k}$ jejichž ochraně (hodnotám, které prezentují) je vystavěna řada právních figur; tyto závěry byly formulovány po předložení argumentů, na kterých staví.

Dochází ke změně ve způsobu realizace určitých činností a $\mathrm{k}$ řadě souvisejících posunů. Okruh zasažených oblastí je přitom široký. Jde o tradiční rodinu, způsob života (uspořádání pracovního a soukromého času), ale i o způsoby výkonu práce. K tomu bylo řečeno, že některé ze stávajících schémat a institutů by bylo vhodné reformovat. At' již jde kupř́íkladu o právní úpravu rodičovské dovolené, či o samotné vymezení statusu zaměstnance, konkrétně o vytvoření nejméně dvou kategorií (statusů) zaměst-

\footnotetext{
* Autor působí na katedře pracovního práva a práva sociálního zabezpečení Právnické fakulty Univerzity Karlovy jako tajemník a odborný asistent. Je místopředsedou České společnosti pro pracovní právo a právo sociálního zabezpečení a advokátem v Praze. Př́íspěvek zohledňuje stav ke dni 1. ř́ijna 2018.
} 
nanců odvozených od charakteru vykonávané práce, či o dílčí doplnění stávajících figur, resp. o jejich posílení, v některých směrech (např. o formulaci práva na odpojení od zaměstnavatele atp.). ${ }^{1}$

Poukázání na problematické aspekty právní úpravy a zdůvodnění přesvědčení, že právní úprava není z nějakého důvodu dostatečná, je však pouze prvním krokem odborného diskurzu. Má-li být dosaženo pozitivního posunu, je nezbytné navázat formulováním možných řešení problematických bodů a předkládáním konstruktivně kritických argumentů ve vztahu k nim, kdy výsledkem takové debaty by mělo být nalezení nejlepšího řešení v kontextu celkové situace. Tento cíl si částečně klade předložený prííspěvek.

\section{RODIČOVSKÁ DOVOLENÁ2}

Z hlediska fyziologického, psychologického i sociálního vývoje a rozvoje dítěte se považuje za zásadní období od narození do jeho nejméně tř́ let věku. Pro budoucí biologický, psychologický i sociální vývoj dítěte a zprostředkovaně tedy i z obecného společenského hlediska je žádoucí, aby byl rodiči dítěte, bude-li mít zájem, poskytnut dostatečný časový prostor pro výchovu dítě v jeho raném věku a k prohloubení vztahů s ním. Již tradiční právní figurou, která má naplnit právě vymezený účel, je rodičovská dovolená. Rodičovská dovolená zakládá právo zaměstnance/zaměstnankyně po zaměstnavateli žádat k prohloubení péče o dítě poskytnutí pracovního volna. Oproti mateřské dovolené (ust. § $195 \mathrm{ZPr}$ ) rodičovská dovolená primárně nenavazuje na zdravotní stav člověka, který ji čerpá.

V návaznosti na individuální a celospolečenské zájmy prezentované účely institutu se s rodičovskou dovolenou, obdobně jako s mateřskou dovolenou, avšak v určitých pozicích v menší intenzitě, pojí i jiné právní důsledky, nežli je pouze poskytnutí pracovního volna (např́iklad jde o ochrannou dobu ve vztahu ke skončení pracovního poměru); tyto zpravidla souvisí se stabilitou pracovního poměru.

Právní úprava rodičovské dovolené má několik problematických aspektů.

Jedním z nich byla po určitou dobu otázka související s délkou čerpání rodičovské dovolené. Konkrétně, zda je v dispozici zaměstnance, který čerpá rodičovskou dovolenou, svým jednostranným jednáním skončit čerpání rodičovské dovolené a nastoupit

1 Zejména viz MORÁVEK, J. Prostředky právní ochrany a právní úprava pracovněprávních vztahů - problematické aspekty. In: DVOŘÁK, J. a kol. Soukromé právo 21. století. Praha: Wolters Kluwer. 2018. s. 332-346; Morávek, J. Prostředky moderní techniky a právní úprava pracovněprávních vztahů v České republice. In: BARANCOVÁ, H. - OLŠOVSKÁ, A. (eds.). Pracovné právo v digitálnej dobe. Olomouc: Leges. 2018; MORÁVEK, J. Sdílená ekonomika nejen z hlediska právní úpravy pracovněprávních vztahů. SOCIETAS ET IURISPRUDENTIA - Medzinárodný internetový vedecký časopis zameraný na právne otázky v interdisciplinárnych súvislostiach. Právnická fakulta Trnavské univerzity v Trnavě. Trnava. 2017. ročník V. svazek 4. s. $124-142$; MORÁVEK, J. Limity právního rádu a sociální stát v době moderních technologií. In: PICHRT, J. - BOHÁČ, R. - MORÁVEK, J. Sdilená ekonomika - sdilený právní problém? Praha: Wolters Kluwer. 2017; MORÁVEK, J. O vhodnosti a nevhodnosti novelizace zákoníku práce. In: GREGOROVÁ, M. (eds.). Pracovní právo 2016 - Zákoník práce v novelizaci, důchodová reforma v akci. Acta Universitatis Brunensis Iuridica, vol. 581, Masarykova univerzita, Brno, 2017, s. 20-54.

2 Vymezení problematických aspektů právní úpravy rodičovské dovolené vychází z př́ispěvku autora MORÁVEK, J. Ke změně některých sociálních paradigmat z hlediska právní úpravy pracovněprávních vztahů. In: KOLDINSKÁ, K. (ed.). Pocta Věre Stangové. Plzeň: Aleš Čeněk, 2018. 
zpět do zaměstnání před dnem, který původně označil jako den, do kterého bude rodičovskou dovolenou čerpat.

V současné době lze brát za nesporné, že bez dostatečně silného legitimního zájmu na straně zaměstnance obecně není prrípustné, nestanoví-li zákon výslovně jinak (viz ust. $\S 198 \mathrm{ZPr}$ ), aby zaměstnanec zaměstnavateli sdělil, že předčasně končí čerpání rodičovské dovolené a dostaví se do zaměstnání. Právo na předčasný návrat do zaměstnání zaměstnanci nesvědčí.

Jsou však i jiné problematické momenty a otázky, které souvisí s uvedeným v úvodní pasáži, tedy s erozí některých tradičních společenských institucí, a ve vztahu k nim prozatím uspokojivé řešení schází.

Kupříkladu, svědčí právo na rodičovskou dovolenou matce/otci (muži, jemuž svědčí domněnka otcovství dle předpisů občanského práva - viz ust. § 776 až § 784 ObčZ, př́íp. také NS 21 Cdo 3533/2009), jenž o dítě reálně nepečuje a ani pečovat objektivně nemůže (nebo nechce), jelikož je dítě například svěřeno do výlučné péče druhého $\mathrm{z}$ rodičů?

Zákoník práce v souvislosti s rodičovskou dovolenou předpokládá toliko rodičovství $\mathrm{k}$ dítěti do tř́ let věku a žádost o pracovní volno. Čistě jazykový výklad tudíž vede k závěru, že zaměstnanci/zaměstnankyni právo na pracovní volno svědčí; lze mít za to, že řada zaměstnavatelů by takovému zaměstnanci rodičovskou dovolenou poskytla, resp. že mu ji poskytla. Není však třeba dalekosáhle zdůvodňovat, proč by přiznání práva na rodičovskou dovolenou v tomto př́padě zcela popíralo smysl a účel institutu.

I za stávající právní úpravy je situace řešitelná následovně. I přes to si však právní jistota určitou korekci právní úpravy žádá.

$\mathrm{S}$ ohledem na povahu důsledků, které plynou z žádosti zaměstnance nebo zaměstnankyně o čerpání rodičovské dovolené (poskytnutí pracovního volna z titulu rodičovské dovolené), je žádost právním jednáním. Žádost tedy musí naplňovat všechny obecné náležitosti právního jednání, jak plynou zejména z předpisů práva občanského (poctivost, srozumitelnost, určitost atp. - viz zejména ust. $\S 6$ až 8 a ust. $\S 545$ an. ObčZ). Žádost takového rodiče, která by byla zjevným zneužitím práva a jednáním mimo smysl a účel právní normy (srov. mj. NS ČR 21 Cdo 624/2001), by na platné právní jednání aspirovat zjevně nemohla.

Obdobná situace může nastat i z druhé strany. Konkrétně např́íklad muži, kterému nesvědčí domněnka otcovství, nicméně žije s matkou dítěte ve společné domácnosti a s ohledem na předpoklad budoucího společného života má skutečný zájem na prohlubování vztahu s (byt' nevlastním) dítětem a o péči o něj, právo na rodičovskou dovolenou nesvědčí, byt' by mu podle smyslu a účelu institutu svědčit mělo. Tento nedostatek však již výkladem odstranit nelze.

Z uvedeného se podává, že by bylo vhodné kriticky zhodnotit instituty obdobné rodičovské dovolené a př́padně provést dílčí korekce tak, aby (převedeno na rodičovskou dovolenou) rodiči, který pečovat o dítě nechce, či z objektivního důvodu, který nelegitimizuje opačný záměr, o dítě pečovat nemůže, právo nesvědčilo. Naopak, pokud je zde člověk, který sice není rodičem dítěte, ale žije s ním ve společné domácnosti a má opravdový zájem o dítě pečovat, dle smyslu a účelu institutu by mu právo na pracovní volno svědčit mělo, stejně jako související pozitivní právní důsledky (ochranná doba atp.). 
Pozitivně lze v tomto směru vnímat právní úpravu dlouhodobého ošetřovného, jak je obsažena v zákoně č. 187/2006 Sb., o nemocenském pojištění. Konkrétně jde-li o možnost péče ze strany druha/družky žijící s ošetřovanou osobou v domácnosti - ust. § 41a odst. 4 zákona č. 187/2006 Sb. zavádí podmínku, že za družku/druha se považuje ten, kdo s dotčeným člověkem má alespoň tři měsíce shodné místo trvalého pobytu.

Obdobné pojetí naznačené podoby rodičovské dovolené de lege ferenda, tedy př́ípad, kdy může rodičovskou dovolenou čerpat jiná osoba nežli rodič dítěte, která však dítě současně neosvojila, za podmínky, že s ním žije ve společného domácnosti a pečuje o něj, lze ostatně vysledovat i v zahraničních právních úpravách, například ve Švédském zákoně č. 1995:584 SFS o rodičovské dovolené, ${ }^{3}$ který vedle rodičovské dovolené (pracovního volna určeného $\mathrm{k}$ péči o dítě a prohloubení vztahů s ním v době po jeho narození) reguluje i materii, kterou bychom v právním řádu České republiky našli v ust. $\S 239$ an. ZPr, tj. právní úpravu zvláštních pracovních podmínek těhotných zaměstnankyn̆, zaměstnankyň matek, zaměstnanců a zaměstnankyň pečujících o dítě.

Zákon přiznává shodná práva, nejen právo na rodičovskou dovolenou, ale i další práva založená jmenovaným zákonem rodičům dítěte:

(a) zaměstnanci, který není rodičem dítěte, avšak je jeho opatrovníkem, pokud se o dítě stará (např́ílad je-li v péči prarodiče),

(b) zaměstnanci, který má dítě v trvalé péči (pěstounovi dítěte), pečuje-li o dítě ve své rodinné domácnosti, či

(c) zaměstnanci, který trvale žije s rodičem dítěte za předpokladu, že zaměstnanec je nebo byl manželem rodiče či má nebo měl dítě $s$ rodičem dítěte.

Z hlediska nastavení tuzemské regulace dále není bez zajímavosti, že právní úprava rodičovské dovolené ve Švédsku je provázána s rodičovskou dávkou v rámci systému sociálního zabezpečení, konkrétně podle zákona č. 2014:948 SFS o sociálním pojištění.

Zákon (ZoRD) zná šest typizovaných případů pracovního volna poskytovaného $\mathrm{v}$ souvislosti s péćí o dítě $\mathrm{v}$ době před a po jeho narození. U řady $\mathrm{z}$ nich lze najít paralelu v rámci zdejší právní úpravy.

\section{A) MATEŘSKÁ DOVOLENÁ (§ 4 ZORD)}

Jedná se o pracovní volno určené pro zaměstnankyni $\mathrm{v}$ době před a po narození dítěte. Pracovní volno se poskytuje v rozsahu plného pracovního úvazku. Z hlediska právního rádu České republiky se jedná o institut srovnatelný s mateřskou dovolenou ve smyslu ust. § 195 ZPr. V určité omezené míře, jde-li o navazující instituty, se právní úprava použije i pro dobu kojení.

Pracovní volno se poskytuje $\mathrm{v}$ délce sedmi týdnů před a sedmi týdnů po narození dítěte. Dva týdny před a po porodu musí být vyčerpány povinně. To neplatí, byla-li před narozením dítěte vyčerpána kratší doba proto, že porod nastal dříve (či z jiného obdobného důvodu).

3 Dále jen $Z o R D$. 


\section{B) PLNÁ (RODIČOVSKÁ DOVOLENÁ) DOVOLENÁ/PRACOVNÍ VOLNO \\ (S RODIČOVSKOU DÁVKOU PODLE ZÁKONA Č. 2014:948 SFS O SOCIÁLNÍM POJIŠTĚNÍ)}

Jedná se o pracovní volno, které se poskytuje v rozsahu plného pracovního úvazku rodiči do 18 měsíců věku dítěte a případně i po této době, má-li zaměstnanec právo na plnou rodičovskou dávku podle zákona č. 2014: 948 SFS o sociálním pojištění; naprríklad při osvojení/převzetí dítěte do péče nahrazující péči rodičů. Pracovní volno lze nicméně i v těchto případech čerpat nejdéle do 8 let věku dítěte nebo do skončení prvého roku školní docházky dítěte podle toho, co nastalo dříve.

Z hlediska právního řádu České republiky se jedná o institut srovnatelný v základu s rodičovskou dovolenou ve smyslu ust. $§ 196 \mathrm{ZPr}$, resp. př́padně s mateřskou a rodičovskou dovolenou při převzetí dítěte do péče ve smyslu ust. § 197 ZPr.

\section{C) ČÁSTEČNÁ RODIČOVSKÁ DOVOLENÁ/PRACOVNÍ VOLNO S RODIČOVSKOU DÁVKOU (§ 6 ZORD)}

Pracovní volno se poskytuje pouze v části pracovního úvazku $(3 / 4,1 / 2$, $1 / 4,1 / 8)$ v návaznosti na to, v jaké míre se poskytuje rodičovská dávka ve smyslu ust. $\S 12$ zákona č. 2014: 948 SFS o sociálním pojištění.

\section{D) ČÁSTEČNÁ RODIČOVSKÁ DOVOLENÁ/PRACOVNÍ VOLNO BEZ RODIČOVSKÉ DÁVKY (§ 7 ZORD)}

Jedná se o zkrácení pracovního úvazku až o 1/4. Zkrácení je možné nejdéle do 8 let věku dítěte. $Z$ hlediska právního řádu České republiky lze institut přirovnat k právní úpravě obsažené v ust. § $241 \mathrm{ZPr}$, tj. k úpravě zkrácení/změně rozsahu pracovního úvazku (nebo rozvržení pracovní doby) k žádosti zaměstnance pečujícího o dítě do 8 let věku, resp. 15 let věku, jde-li o osamělého zaměstnance.

\section{E) RODIČOVSKÁ DOVOLENÁ/PRACOVNÍ VOLNO S DOČASNÝM RODIČOVSKÝM PŘÍSPĚVKEM (§ 8)}

Jedná se o pracovní volno na nezbytně nutnou dobu, kdy rodič musí pečovat o dítě např́iklad z důvodu nemoci. $Z$ hlediska právního řádu České republiky by bylo možné přirovnat tuto situaci k překážkám v práci formulovaným v ust. $\S 191$ ZPr, kdy se poskytuje pracovní volno v souvislosti s nezbytnou péčí o dítě, konkrétně: ,,po dobu ošetrováni dítěte mladšího než 10 let nebo jiného člena domácnosti v př́padech podle § 39 zákona o nemocenském pojištění a po dobu péče o ditě mladši než 10 let $z$ di̊vodi̊ stanovených $v$ \& 39 zákona o nemocenském pojištění nebo z důvodu, kdy se fyzická osoba, která o ditě jinak pečuje, podrobila vyšetřeni nebo ošetření u poskytovatele zdravotnich služeb, které nebylo možno zabezpečit mimo pracovni dobu zaměstnance, a proto nemůže o dítě pečovat." 
Pracovní volno se poskytuje v rozsahu plného pracovního úvazku či v jeho polovině. $V$ tomto prrípadě je pracovní volno navázáno na nárok rodiče na příspěvek na východu podle $\S 8$ zákona č. 2008: 307 o obecním příspěvku na východu dětí.

Inspirativní však může být Švédská úprava i v jiných aspektech.

Dle ust. $\S 10$ ZoRD lze rodičovskou dovolenou čerpat po částech. $\mathrm{V}$ rámci kalendářního roku svědčí zaměstnanci právo třikrát jednostranně změnit své rozhodnutí stran čerpání x nečerpání pracovního volna (rodičovské dovolené). Pokud čerpání (rozhodnutí) přesáhne do následujícího kalendářního roku, započítá se čerpání pouze do roku, ve kterém bylo čerpání zahájeno. Zaměstnanec, pokud jde pouze o částečnou dovolenou (zkrácení úvazku), může rodičovskou dovolenou čerpat pouze v některé dny v týdnu např́íklad v pondělí a ve středu otec, $v$ úterý, ve čtvrtek a v pátek matka; v tomto jde tedy o právní úpravu v principu shodnou s ust. § $241 \mathrm{ZPr}$, na nějž již bylo poukazováno shora.

Zákon preferuje dohodu. Vedle toho nicméně zaměstnanci přiznává právo na určení čerpání, stejně jako právo na změnu čerpání či právo na předčasný návrat do zaměstnání. Zaměstnavatel nemusí zaměstnanci $\mathrm{k}$ žádosti o předčasný návrat vyhovět pouze tehdy, jsou-li pro to vážné provozní důvody (zájem zaměstnavatele převáží nad zájmem zaměstnance).

Čerpání, příp. změna se oznamuje nejméně dva měsíce předem. Není-li to možné, je předepsána lhůta k oznámení bez zbytečného odkladu. Výjimkou je pracovní volno ve smyslu písm. e) shora, kde činí lhůta jeden týden, nejde-li o nemoc nebo jiný důvod čerpání pracovního volna, kde lhůta k předchozímu oznámení předepsána není a volno lze čerpat bezprostředně.

Rozhodnutí zaměstnance o předčasném návratu do zaměstnání zaměstnanec zaměstnavateli oznamuje bez zbytečného odkladu. Zaměstnavateli svědčí právo návrat zaměstnance oddálit až o 1 měsíc od oznámeného data návratu do zaměstnání, pokud se jedná o př́ípad, kdy bylo pracovní volno podle původního oznámení zaměstnance čerpáno $\mathrm{v}$ rozsahu jednoho měsíce nebo déle.

Dohoda zaměstnance a zaměstnavatele, která by zkracovala zaměstnance na jeho právech, je stíhána neplatností.

Odchýlení se od zákona je možné prostřednictvím kolektivní smlouvy, jde-li např́íklad o úpravu oznámení dovolené ve smyslu ust. § 13 ZoRD, doby, kdy má zaměstnanec povinnost oznámit návrat do zaměstnání ve smyslu ust. § 15 odst. 2 ZoRD, či doby, po kterou je zaměstnavatel oprávněn oddálit návrat zaměstnance do zaměstnání ve smyslu $\S 15$ odst. 3 ZoRD. 


\section{VYBRANÉ OTÁZKY PRACOVNÍ DOBY, DOBY ODPOČINKU A DOVOLENÉ}

Právní úpravu pracovní doby, doby odpočinku a dovolené není důvod v generální rovině hodnotit negativně. Uvedené však neznamená, že neexistují problematické momenty. Ne všechny však jsou důsledkem legislativní činnosti. Některé plynou spíše z nevhodně zaužívané praxe a z nesprávné interpretace zákonodárství. Za všechny lze poukázat na dva príklady.

Jednak na zákonem předepsanou dobu (ust. § $84 \mathrm{ZPr}$ ) pro seznámení zaměstnance s rozvrhem směn, kdy slova „nedohodnou-li se jinak“ jsou aktuálně interpretována tak, že možná je i dohoda na kratší době pro seznámení, než je zákonem předepsaná doba 2 týdnů, resp. 1 týdne, a dále o právní úpravu konta pracovní doby, kdy právní úprava nijak nereflektuje vůli dotčeného zaměstnance.

Je částečně překvapující, že jak dřívější návrh novely zákoníku práce (tisk 903/0 viz shora), tak stávající podoba připravované novely zákoníku práce ${ }^{4}$ bud'to na tyto problematické momenty vůbec necílí, nebo pokud ano, tak ze špatné strany. Vedle toho se naopak věnuje změně institutů, které problematické nejsou a novelizaci se tudíž nežádají, jako je právní úprava dovolené.

$\mathrm{V}$ této souvislosti lze jak k navržené změně ust. $\S 84 \mathrm{ZPr}$, tak k nově navrhované podobě právní úpravy dovolené $\mathrm{v}$ krátkosti poukázat na dříve uvedené 5 a již nanesené argumenty doplnit o související úvahy, včetně námětů de lege ferenda vyplývajících z právních řádů jiných zemí.

\subsection{DOBA PRO SEZNÁMENÍ ZAMĚSTNANCE S ROZVRHEM SMĚN A ROZVRŽENÍ PRACOVNÍ DOBY}

Stávající právní úpravu ust. § $84 \mathrm{ZPr}$ (předepsanou dobu dvou týdnů) lze považovat za minimální $\mathrm{k}$ tomu, aby člověk dokázal racionálně plánovat svůj soukromý a rodinný život - dokázal pro sebe a svou rodinu určit, který čas bude věnován práci, a který bude věnován společným aktivitám, naplánoval si soukromé záležitosti běžného života, jako je návštěva zubního lékaře atp. Situace, kdy zaměstnanec neví, zda bude či nebude povolán $\mathrm{k}$ výkonu práce ze dne na den, která je dnes $\mathrm{v}$ aplikační praxi pravidlem, nebot' je hojně využívána (nesprávně) dovozená dispozitivnost právní úpravy ve směru k možnému zkrácení zákonné lhůty, a to až na řády dnů či hodin, nedává žádnou jistotu pro zaměstnance a ani jeho rodinu. ${ }^{6}$

4 Viz $<$ https://apps.odok.cz/veklep-detail?pid=ALBSB3QAMAG7>.

$5 \mathrm{~K}$ tomuto srov. taktéž MORÁVEK, J. Seznámení zaměstnance s rozvržením pracovní doby v perspektivách času. In: HROMADA, M. (eds.). Pocta Jarmile Pavlátové k 85. narozeninám. Plzeň: Západočeská univerzita v Plzni, 2018, s. 31-41, nebo MORÁVEK, J. O vhodnosti a nevhodnosti novelizace zákoníku práce. In: GREGOROVÁ, Z. (eds.). Pracovní právo 2016 - Zákoník práce v novelizaci, důchodová reforma v akci. Acta Universitatis Brunensis Iuridica. vol 581, Masarykova univerzita, Brno, 2017, s. 20-54.

6 A to hovoříme o standardní rodině a rodinném životě. Ještě závažnější by situace byla v momentě, kdy je kupř́íkladu dítě ve stř́idavé péči. Argumentace přesčasovou prací v této souvislosti není na místě. Jednak je přesčasová práce vázána na podmínku, že může být konána jen výjimečně. Jednak je přesčasová práce časově omezena. Částečně relevantní je v tomto směru toliko právní úprava zvláštních pracovních podmínek některých zaměstnancủ, jak je obsažena primárně v ust. § 237 an. ZPr. 
Stávající právní úprava obsažená v ust. § 84 ZPr navazuje na úpravu ust. § 85 zákona č. 65/1965 Sb., zákoník práce. ${ }^{7}$ Rozdíl úprav spočívá pouze $\mathrm{v}$ dílčím odlišném věcném dosahu, když ZP65 povinnost v časovém předstihu zaměstnance seznámit s rozvrhem pracovní doby vztahoval pouze $\mathrm{k}$ pracovní době, která byla rozvrhována nerovnoměrně, kdežto podle stávající právní úpravy dopadá povinnost na všechny př́ípady.

Stran účelu právní úpravy důvodová zpráva ${ }^{8} \mathrm{k}$ ust. $\S 84 \mathrm{ZPr}$ nic konkrétního nestanoví. Pouze omezeně je $\mathrm{v}$ tomto směru relevantní odkaz $\mathrm{v}$ důvodové zprávě na ust. § 13 ZPr v původním znění. Ustanovení § 13 ZPr obsahovalo určité základní principy a zásady, které lze dnes částečně nalézt v ust. § 346b an. ZPr. Dle ust. § 13 odst. 3 ZPr pak zaměstnanec měl mj. právo na rozvržení pracovní doby před zahájením práce, přičemž však v kontextu důvodové zprávy měla být dikce určující primárně pro rozlišení odlišné povahy dohod o pracích konaných mimo pracovní poměr a pracovního poměru, kdy v př́ípadě dohod povinnost rozvrhnout pracovní dobu předepsána není.

Jelikož je jádro právní úpravy v ZPr a v ZP65 totožné, lze se při hledání účelu právní regulace obrátit k zákonu č. 155/2000 Sb., kterým se mění zákon č. 65/1965 Sb., zákoník práce, ve znění pozdějších předpisů, a některé další zákony, jímž bylo předmětné ustanovení do zákonné dikce ZP65 vtěleno. V důvodové zprávě ${ }^{9}$ se ke změně uvádí: „Nově se zar̆azuje povinnost zaměstnavatele stanovit pisemně rozvrh nerovnomèrného rozvržení pracovní doby, což má ve svém důsledku zajistit ochranu oprávněných zájmů zaměstnanců i zaměstnavatelü.“

Vedle toho, a to je neméně důležité, lze právní úpravu ust. § 85 odst. 3 ZP65, resp. $\S 84$ ZPr brát z jistého hlediska za reakci na směrnici Evropského parlamentu a Rady 2003/88/ES ze dne 4. listopadu 2003 o některých aspektech úpravy pracovní doby. Byt' ust. $§ 84 \mathrm{ZPr}$ nefiguruje $v$ ust. $§ 363 \mathrm{ZPr}$ a nejde tedy o transpozici v pravém smyslu slova, lze se kvůli nedostatečné deklaraci účelu regulace ze strany zákonodárce klonit k závěru, že jmenované ustanovení, stejně jako ust. § 85 ZP65, by mělo být nahlíženo a aplikováno také v kontextu výkladového cíle plynoucího z recitálu č. 11 směrnice 2003/88/ES, dle kterého: „Organizace práce podle určitého rozvrhu musí prihližet $k$ obecné zásadě, že práce musí být prizizpơsobena člověku.“"

Bez významu dále není, že před novelizací ZP65 žádnou konkrétní povinnost $\mathrm{v}$ určitém časovém předstihu zaměstnance informovat o rozvržení pracovní doby do směn nepředepisoval. Právní úprava stavěla dle všeho na shodném schématu jako smlouva služební a smlouva o dílo (ust. § 1151 an. o.z.o), resp. až do přijetí císařského nařízení č. 96 ř. z. ze dne 19. března 1916 smlouva námezdní. $Z$ dobové judikatury (např. NS Rv I 654/39) stejně jako z dobové literatury plyne, že „délka denního zaměstnání ř́dí se úmluvou (ovšem v mezích zákonných) a, neni-li jí, dlužno uznati podle mistního zvyku na dobu přiměrenou." 10

7 Dále jen ZP65.

8 Parlament České republiky, Poslanecká sněmovna, 2002-2006, tisk 1153/0.

9 Parlament České republiky, Poslanecká sněmovna 1998-2002. tisk 484/0.

10 ROUČEK, F. - SEDLÁČEK, F. a kol. Komentáŕ k československému obecnému zákoníku občanskému a občanské právo platné na Slovensku a v Podkarpatské Rusi. Díl. V. §§ 1090-1341, Praha: Wolters Kluwer. 2013. s. 248. 
Při nedostatečně deklarovaném cíli právní regulace nezbývá, než obecný účel ,zajistit ochranu oprávněných zájmů zaměstnanců i zaměstnavatelü“ a tedy i právní úpravu samu, vnímat a číst prizmatem interpretačního předpokladu racionálního zákonodárce; zejména s přihlédnutím $\mathrm{k}$ tomu, že žádná konkrétní povinnost $\mathrm{v}$ předepsaném časovém předstihu zaměstnance informovat o rozvržení pracovní doby do směn dříve stanovena nebyla, a dále s ohledem na technologické změny a změny ve způsobu výkonu práce, které technologické změny (rozvoj komunikačních technologií, elektronických médií a výpočetní techniky, které umožňují neustálé spojení zaměstnance se zaměstnavatelem, a stírají tak postupně hranici mezi časem vyhrazeným práci a časem vyhrazeným pro soukromý a rodinný život) v určitých segmentech hospodářství přinesly, ale i s ohledem na strukturu převážné části tuzemských podnikatelů/zaměstnavatelů.

Náhled právní úpravy optikou racionálního zákonodárce vede k následujícím závěrům.

Tradiční tovární nebo obdobná průmyslová výroba je zpravidla realizována prostřednictvím zaměstnanců se směnným rozvržením pracovní doby. Vytvořit směnný rozvrh pracovní doby ve velkém nepřetržitém provozu pro řádově desítky, resp. stovky či větši počet zaměstnanců vyžaduje relativně náročné a složité plánování a značné úsilí. Pracovní doba tudíž bývá rozvrhována na týdny či měsíce dopředu a je tak jen málo pravděpodobná častá a překotná změna rozvržení pracovní doby. Jinak je tomu zpravidla v oblasti služeb, v malých provozech a u drobných podnikatelů. Zde je žádoucí flexibilita, přičemž tato potřeba bývá ještě dále podpořena, jedná-li se o kreativní činnost, působení a uplatňování moderních technologií v pracovním procesu.

Pokud schází odpovídající právní figury umožňující flexibilní výkon práce (práce na zavolanou, odpovídající pravidla pro práci mimo pracoviště zaměstnavatele atp.), vedou takové okolnosti přirozeně $\mathrm{k}$ tendenci zaměstnavatelů, je-li možné si ujednat časový předstih, ve kterém bude zaměstnanci muset být oznámeno rozvržení pracovní doby do směn, nezbytnou dobu pro seznámení co možná nejvíce zkrátit. Př́lišs krátká doba pro seznámení se s rozvrhem směn nebo s jeho změnou však má pro zaměstnance (jeho soukromý a rodinný život a pro jeho rodinu vůbec) shora popsané negativní důsledky.

Za těchto okolností je přirozeným projevem úvahy racionálního zákonodárce, který zohledňuje všechny zmíněné aspekty a dotčené zájmy a hodnoty (základní práva a svobody), stanovit minimální dobu, ve které zaměstnanec musí být seznámen s rozvrhem směn nebo s jeho změnou. ${ }^{11}$ Výsledek vážení došel pozitivního vyjádření v ust. $§ 85$ ZP65 a v ust. § $84 \mathrm{ZPr}$.

Za těchto předpokladů se pak nezdá být správný závěr dovozovaný v odborné literatuře, ${ }^{12}$ že ust. $\S 84$ ZPr je dispozitivní v obou směrech, tj. umožňuje dohodu zaměstnance a zaměstnavatele o prodloužení předepsané doby stejně jako o jejím zkrácení; z povahy věci bývá $v$ aplikační praxi doba delší dohadována zcela výjimečně, naopak

11 Stejné platí pro př́ípady, kdy po vyhodnocení situace je učiněn závěr, že dřívější opatření dotýkající se pouze nerovnoměrného rozvržení pracovní doby, není dostatečné, a je třeba přistoupit k jeho rozšsiŕení i na rovnoměrné rozvržení pracovní doby.

12 Viz např́iklad ŠTEFKO, M. In: BĚLINA, M. - DRÁPAL, L. a kol. Zákoník práce. Velký komentářr. 2. vyd. Praha: C. H. Beck. 2015. s. 532. 
kratší doba je dohadována pravidelně a není výjimečné, aby doba pro seznámení s rozvrhem směn či s jeho změnou byla ujednána v rozsahu jednoho dne, nebo dokonce v řádech hodin (je samozřejmě otázka, zda lze hovořit o dohodě v momentě, kdy pracovní smlouva má de facto povahu smlouvy adhezní).

Krátce řečeno, vycházeje z Ústavním soudem České republiky opakovaně potvrzené teze (viz např. ÚS ČR ve věci sp. zn. Pl. ÚS 33/97), jež stojí v základu demokratického právního státu, a která našla své pozitivní vyjádření pro oblast soukromého práva v ust. $\S 2$ odst. 1 ObčZ ${ }^{13}$, a s přihlédnutím k zásadě ochrany slabší strany, resp. zvláštní zákonné ochraně postavení zaměstnance, lze dospět k závěru, že od ust. § 84 ZPr by mělo být možné se platně odchýlit pouze ve prospěch zaměstnance, tedy tak, že se dohodou zaměstnance a zaměstnavatele doba prodlouží a nikoli zkrátí.

V uplynulém volebním období Poslanecké sněmovny Parlamentu České republiky byla navržena novelizace ust. $§ 84$ ZPr, která byla prezentována jako kompromis mezi návrhem zástupců zaměstnavatelů a návrhem zástupců zaměstnanců. Konkrétně se navrhovalo ust. $\S 84$ ZPr doplnit takto: „Zaměstnavatel je povinen vypracovat písemný rozvrh týdenní pracovní doby a seznámit s ním nebo s jeho změnou zaměstnance nejpozději 2 týdny a v připadě konta pracovni doby 1 týden před začátkem období, na něž je pracovní doba rozvržena, pokud se nedohodne se zaměstnancem na jiné době seznámení, která však nesmí být kratši než 2 dny. "14 Dle důvodové zprávy se jedná „o věcnou změnu týkající se pravidel rozvrhování pracovní doby zaměstnancưm. Předkladatel $v$ rámci pravidel o písemném rozvrhování týdenni pracovní doby zaměstnanci usiluje o to, aby ani v př́padě dohody zaměstnavatele se zaméstnancem na jiné kratši době seznámení s rozvrhem týdenní pracovni doby, než jsou zákonné 2 týdny předem, nemohlo docházet $k$ seznámení s rozvrhem či jeho změnou bezprostředně před výkonem práce, tj. k práci na zavolanou. Návrh je odrazem kompromisního řě̌ení (pozn. autora návrhu zástupců zaměstnavatelů 1 den předem a návrhu zástupců zaměstnanců 3 dny předem) a stanovuje, že zaměstnanec musí být seznámen s rozvrhem pracovní doby či s jeho změnou minimálně 2 dny předem. Jde o snahu o vylepšení podmínek slad'ování rodinného a pracovního života a zamezeni prekérnosti práce na zavolanou. "Novelizační bod shodného znění je začleněn i do aktuálně připravované novely zákoníku práce. ${ }^{15}$

Ze shora uvedeného se však podává, že pokud by měla být provedena novelizace, pak tak, aby rozhodná část zákonné dikce zněla zhruba následovně: „Zaměstnavatel je povinen vypracovat písemný rozvrh týdenní pracovní doby a seznámit s ním nebo s jeho změnou zaměstnance nejpozději 2 týdny a v př́padě konta pracovní doby 1 týden pred začátkem období, na něž je pracovni doba rozvržena, pokud se nedohodne se zaměstnancem na jiné delší době seznámeni. “Výjimku z tohoto pravidla si lze představit v mimořádných situacích (živelní událost atp.) nebo po dohodě s odborovou organizací, bude-li to s ohledem na povahu provozu nezbytné.

13 Ust. § 2 odst. 1 ObčZ: „Každé ustanovení soukromého práva lze vykládat jenom ve shodě s Listinou základnich práv a svobod a ústavním pořádkem vůbec, se zásadami, na nichž spočivá tento zákon, jakož is trvalým žretelem $k$ hodnotám, které se tím chrání. Rozejde-li se výklad jednotlivého ustanovení pouze podle jeho slov s tímto př́kazem, musí mu ustoupit."

14 Parlament České republiky. Poslanecká sněmovna 2013-2017. tisk. 903/0.

$15 \mathrm{Viz}<\mathrm{https}$ ://apps.odok.cz/veklep-detail?pid=ALBSB3QAMAG7>. 
Takový model by nebyl novinkou. Zná jej např́klad švédský zákon 1982: 673 SFS o pracovní době. ${ }^{16}$ Dle ust. $\S 12$ ZoPD je mj. zaměstnavatel povinen zaměstnanci vykonávajícímu práci v pracovním poměru na dobu neurčitou rozvrhovat pracovní dobu, resp. seznámit ho se změnou organizace pracovní doby, nejméně 2 týdny předem. Kratší doba je možná, žádá-li si to povaha vykonávané práce nebo mimořádná událost. Co je v tomto právním prostředí typické, od základní zákonné úpravy je možné se odchýlit prostřednictvím kolektivní smlouvy.

V úvahách úvah o novelizaci zákoníku práce ve vztahu ke stávající právní úpravě pracovní doby a doby odpočinku nicméně nabízí Švédská právní úprava i několik dalších podnětů.

S ohledem na shodný podklad $v$ evropské regulaci (směrnici 2003/88/ES) je právní úprava $\mathrm{v}$ řadě aspektů přirozeně obdobná, byt' $\mathrm{i}$ transponovaná úprava je dílčím způsobem doplněná odlišně. Kupř́kladu (ust. § 13 ZoPD) evropský standard denního odpočinku v minimálním rozsahu 11 hodin v rámci 24 hodin po sobě jdoucích by měl být dle švédské právní úpravy nařizován, pokud možno tak, aby byl čerpán mezi 24:00 a 5:00. Přestávka v práci (dle zdejší terminologie přestávka na jídlo a oddech) zaměstnanci náleží (ust. § 15 ZoPD) nejdéle po 5 hodinách nepřetržitého výkonu práce. Délka přestávky prritom není upravena. Stanoví se pouze, že počet přestávek, délka jejich trvání a organizace musí být uspokojivé z hlediska podmínek výkonu práce. ${ }^{17}$

V návaznosti na nedávno vedený odborný diskurs k otázce výkladu a aplikace zdejší právní úpravy doby nepřetržitého odpočinku v týdnu se dále nabízí poukázat na ust. $\S 14$ ZoPD. Dle odkazovaného ustanovení zaměstnanci náleží nepřetržitý odpočinek v rozsahu 36 hodin za každých 7 dní. ${ }^{18}$

Dále se nabízí zmínit právní úpravu přesčasové práce obsaženou v ust. § 7 an. ZoPD. Dle odkazovaných ustanovení je přesčasová práce možná při zvýšené potřebě počtu pracovních hodin (z provozních nebo z jiných obdobných důvodů) nejvýše však v rozsahu 200 hodin za kalendářní rok. Ust. § 8a ZoPD dále zná tzv. dodatečné (extra) přesčasové hodiny v rozsahu až 150 hodin za kalendární rok s tím, že extra přesčas v rámci tohoto limitu je možné zaměstnanci nařídit jedině, jsou-li pro to vážné důvody a není-li možné potřebu pracovní síly pokrýt jiným rozumným opatřením. V úhrnu je tudíž možné dosáhnout až 350 hodin přesčasové práce za rok s tím, že maximální rozsah přesčasové práce za 4 týdny nesmí přesáhnout 48 hodin, resp. za kalendářní měsíc 50 hodin. Př́íplatek za práci přesčas záleží na kolektivní smlouvě.

16 Dále jen ZoPD.

17 Právní úprava započítávání přestávky do pracovní doby je obdobná úpravě obsažené v zákoníku práce. V dalším se švédská právní úprava taktéž v mnohém podobá. Kupříkladu maximální rozsah pracovního úvazku je navázána taktéž na pracovní smlouvu (a př́ípadně druh práce u zaměstnavatele). Jinak řečeno, je možné mít více pracovní úvazku. U zletilých zaměstnanců nedochází ke sčítání pracovní doby v jednotlivých úvazcích.

18 Dále lze poukázat na oproti tuzemské právní úpravě podrobnější úpravu pracovní pohotovosti. Dle ust. § 6 ZoPD je možné držet pracovní pohotovost na telefonu maximálně v rozsahu 48 hodin za 4 týdny, nebo 50 hodin za kalendářní měsíc. 
Vedle základní právní úpravy přesčasové práce částečně stojí právní úprava obsažená v ust. $\S 9$ ZoPD, která upravuje výkon (přesčasové) práce $\mathrm{v}$ době mimořádných událostí (např. živelní událost atp.).

Obecné omezující pravidlo (vycházející ze směrnice 2003/88/ES) regulující úhrnný maximální rozsah výkonu práce obsahuje ust. §16 ZoPD, dle kterého výkon práce v rámci vyrovnávacího období 4 měsíců nesmí přesáhnout 48 hodin v týdnu v průměru.

\section{ZMĚNA PRÁVNÍ ÚPRAVY DOVOLENÉ}

Aktuálně již opakovaně navrženým novelizačním bodem ve vztahu k zákoníku práce, ohledně nějž bezezbytku platí, že nejsou dány důvody a splněny podmínky pro změnu právní úpravy, je komplexní změna právní úpravy dovolené. S ohledem na dobu, po níž se stávající systém dovolené v podstatě bezproblémově uplatňuje, s ohledem na náklady, které s sebou změna ponese (softwarové vybavení, školení zaměstnanců, spory vzniklé z nové právní úpravy atp.), z nichž mnohé budou plynout zejména ze složitosti nové úpravy, stejně jako s ohledem na vy̌šśí administrativní zátěž, kterou nový systém skrývá, by byla taková změna možná pouze na základě důsledné a podrobné analýzy stávajícího stavu, z níž by vyplynulo, že uplatňováním stávajícího sytému dochází k zásadním a nikoli výjimečným nespravedlnostem. Taková analýza však zjevně provedena nebyla, nebo to alespoň $\mathrm{z}$ důvodové zprávy ani $\mathrm{k}$ jednomu $\mathrm{z}$ návrhů neplyne. $\mathrm{Z}$ dosavadních poznatek $\mathrm{z}$ advokátní praxe naopak plyne, že zaměstnanci ani zaměstnavatelé stávající systém výpočtu dovolené nevnímají jako problematický či nějak hrubě nespravedlivý.

I přes tuto zásadní výhradu, která by v podstatě sama stačila $\mathrm{k}$ odmítnutí celé navržené koncepce, v krátkosti několik poznámek.

Institut dovolené, i v kontextu evropské právní úpravy, která má být zdejší legislativou provedena, má být vystaven na základě dříve provedených zdravotních analýz tak, aby zaměstnanec čerpal dovolenou nejméně v rozsahu 4 (pracovních) týdnů v roce, ideálně v celku. Nepřetržitý odpočinek v rozsahu 4 týdnů za rok by měl vést $\mathrm{k}$ regeneraci pracovní síly zaměstnance a $\mathrm{k}$ jeho dlouhodobě dobrému zdravotnímu stavu. Není-li možné čerpat 4 týdny v celku, měla by být dovolená čerpána tak, že alespoň jedna její část činí 2 týdny v celku. Je nicméně možné ujednat si i kratší dobu čerpání dovolené. Nejkratší část dovolené činí půlden.

Dikce stávající právní úpravy vede k praxi, že dovolená nebývá čerpána v kratších časových úsecích, nežli je jeden den. Často bývá čerpána po jednotlivých týdnech. Takto bývají zpravidla vyčerpány dva až tři týdny. Zbytek je čerpán po jednotlivých dnech.

I takové nakládání s dovolenou, kdy je, byt’ z části, čerpána po dnech, je de facto $\mathrm{v}$ rozporu se smyslem institutu. Byt navrhovaná právní úprava nepředpokládá, že by bylo možné čerpat dovolenou po hodinách, nelze se vyhnout obavám, že v praxi nebude čtena jinak, což (byt' se bude jednat o postup v rozporu se zákonem) povede ještě k větší atomizaci čerpání dovolené. To není rozhodně žádoucí.

Dále, nově navržená koncepce předpokládá důsledné vedení evidence pracovní doby, když operuje s odpracovanými týdenními pracovními dobami. Takový požadavek je v kontextu základních povinností zaměstnavatele rozumný. V praxi však 
může způsobit problémy, nebot' řada zaměstnavatelů v tomto směru nepostupuje úplně svědomitě. Tento argument však pro přijetí či odmítnutí nové koncepce nemůže být relevantní. Pouze potvrzuje, že při formulování institutu nebylo př́liš hleděno na poznatky z aplikační praxe.

Co však částečně relevantní být může, je, že v rámci nové koncepce nebude možné zjistit nárok na dovolenou obratem (bude potřeba znát přesný počet odpracovaných hodin), což může být problematické např́íklad při vyjednávání o skončení pracovního poměru, které vede vedoucí zaměstnanec se zaměstnancem.

Není zřejmé, proč se $\mathrm{v}$ nové koncepci neoperuje s celým kalendárním rokem, ale s 52 týdny. Kalendářní rok má 52 týdnů a 2 dny, př́p. 1 den.

$\mathrm{K}$ diskusi je jistě i nově navržená právní úprava krácení dovolené. $\mathrm{V}$ této souvislosti je třeba vidět zejména fakt, že zaměstnavatelé využívají institut krácení dovolené primárně a v podstatě výlučně při skončení pracovního poměru okamžitým zrušením pro zvlášt' hrubé porušení pracovní kázně. V těchto případech se nezdá stávající sankční podoba institutu nepřiměřená.

Stranou by nemělo zůstat ani šiřeji pojaté posuzování důležitých osobních překážek v práci za výkon práce pro účely výpočtu dovolené, zejména jde-li o ženy čerpající mateřkou a rodičovskou dovolenou. V této souvislosti si lze položit otázku, zda opatření na jejich podporu, jak je nastaveno ve vztahu k právní úpravě dovolené a ve vztahu $\mathrm{k}$ návratům z překážek $\mathrm{v}$ práci (ust. § 206a ZPr ve znění novely), jde-li o návrat z rodičovské dovolené, nemůže mít opačný efekt. Konkrétně, zda místo větší ochrany této skupiny zaměstnanců nemůže způsobit ještě složitější pozici zejména žen v plodném věku na trhu práce.

A konečně $\mathrm{k}$ otázce rovnosti a nedokonalosti stávajícího sytému. Žádný právní institut není a pravděpodobně nikdy nebude dokonalý, tedy nebude řešit všechny př́pady stejně a nebude generovat pro všechny stejné podmínky a důsledky. Pod tímto úhlem pohledu je důvod pro změnu institutu pouze tehdy, působí-li nedůvodné (a závažné) nespravedlnosti nebo nabízí-li se jiné (nové) řešení, které je spravedlivější (z hlediska aktuálního uspořádání hodnot) a lze u něj důvodně předpokládat, že jím přivozené pozitivní důsledky převáží pravděpodobné náklady a jiné negativní projevy na straně adresátů, bude-li zavedeno. Tento předpoklad zde však naplněn není.

Navíc navrhovaný model zdaleka není bez chyby. I zde si lze dost dobře představit př́pady, kdy vzniknou nerovnosti, resp. př́ípady, které nebudou odpovídat povaze institutu.

Nabízí se kupříkladu situace, kdy bude osamělá zaměstnankyně (ust. § 350 odst. 1 ZPr) pečující o dítě do 15 let věku pracovat na pracovní úvazek v rozsahu stanovené týdenní pracovní doby v rovnoměrném rozvržení pracovní doby. Tento režim se vůči ní bude uplatňovat 39 týdnů od počátku kalendářního roku. Po tuto dobu nebude čerpat žádnou dovolenou, dovolenou má plánovánu až v poslední čtvrtině roku. Zaměstnankyně si požádá v souvislosti s péčí o dítě o zkrácení pracovního úvazku na 0,25 násobek stanovené týdenní pracovní doby.

Za této situace zaměstnankyni vznikl za první 3/4 roku (ust. § 213 odst. 4 ZPr ve znění novely) nárok na dovolenou v rozsahu 120 hodin. Ve zbytku roku jí vznikne nárok na dovolenou v rozsahu 10 hodin. Celkový nárok na dovolenou tudíž bude činit 
130 hodin. S ohledem na to, že zaměstnankyně pracuje nově v režimu 10 hodinového pracovního týdne, činí její celkový nárok (jelikož navrhovaný systém nezná žádné korekční nástroje) na dovolenou ke konci roku 13 týdnů z hlediska režimu nově určeného rozsahu pracovního úvazku.

Takový důsledek zjevně neodpovídá smyslu institutu, který v této části váže na organizační funkci pracovního práva.

Navrhovaný způsob určování rozsahu nároku na dovolenou je (minimálně v Evropě) netypický. Jen několik př́kladů, nezná ho ani Slovenský zákon č. 311/2001 Z. z., zákoník práce, ani Rakouský zákon č. 390/1976 BGBI, o sjednocení práva na dovolenou a o nároku na pracovní volno, a ani Švédský zákon č. 1977: 480 SFS o dovolené. 19, 20

Právní úpravy jsou možná až překvapivě rozdílné, když některé hovoří o nároku ve dnech, některé v týdnech, některé přiznávají nárok na dovolenou v různém rozsahu dle věku či doby trvání pracovního poměru, mají rozdílné momenty a podmínky vzniku nároku, stejně tak jako pravidla o tom, zda, $v$ jakém rozsahu a kdy má dovolená povahu placeného volna atp. Žádná z nich však nejde navrhovanou cestou přepočtu přes hodiny (a naplněných stanovených týdenních pracovních dob), která se, jak bylo uvedeno shora, příčí účelu právní úpravy; žádná taktéž neobsahuje tak složitý výpočtový vzorec zohledňující mj. skutečně odpracované hodiny atp.

Kupříkladu Švédská právní úprava předepisuje 25 dní pracovního volna ročně, přičemž však stanoví v ust. $\S 7$ ZoD klíč, jehož prostřednictvím se vypočte, kolik z dní pracovního volna bude placených. Rozhodným obdobím pro zjišt'ování nároku na dovolenou je pak období od 1 . dubna do 31. března následujícího kalendářního roku. Pokud pracovní poměr vznikne, resp. zaměstnanec započne s výkonem práce po 31 . srpnu, má nárok pouze na 5 dní dovolené za období od vzniku pracovního poměru do konce období podle předchozí věty. Při zaměstnání kratším 3 měsíců právo na dovolenou nevzniká, zaměstnanci však náleží finanční kompenzace odpovídající počtu dní placené dovolené, na které by mu v pracovním poměru na delší dobu za takové období vznikl nárok.

Dovolená se poskytuje zásadně $\mathrm{v}$ celých kalendářních dnech, přičemž v červnu až v srpnu by měli být poskytnuty 4 týdny dovolené v celku; to neplatí, žádají-li si to důležité důvody. Jeden týden dovolené je možné převést do následujícího roku, resp. převádět jej spolu s dalšími „uspořenými“ dny po dobu dalších 5 let; smyslem je, aby si zaměstnanec mohl za každých 5 let vybrat 10 týdnů dovolené vcelku.

Švédská právní úprava dovolené a spolu s ní i právní úprava pracovní doby nabízí širokou možnost reagovat prostřednictvím kolektivních smluv.

19 Dále jen ZoD.

20 Tento „př́iběh“ je až nápadně podobný právní úpravě okamžitého zrušení základního pracovněprávního vztahu zákonným zástupcem nezletilého zaměstnance, jak byla od 1. ledna 2014 do 27. února 2017 obsažena v zákoníku práce a v občanském zákoníku, než zákonodárce zjistil, co tvrdila většina odborné veřejnosti od samého počátku (viz například MORÁVEK, J. Skončení pracovního poměru - aspekty NOZ. Acta Iuridica Olomucensia, vědecký časopis právnický, sv. 8, 2013, s. 43-56), tedy že taková úprava je nesmyslná a nepoužitelná a fakt, že jí má pouze Finsko (jak vyplývalo z důvodové zprávy - viz Parlament České republiky, Poslanecká sněmovna 2010-2013, tisk 362/0), kdežto ostatní dvě řešení mají např́iklad Belgie, Estonsko, Litva, Mad'arsko, Německo, Nizozemsko, Rusko, Švýcarsko, není projevem toho, že pracovněprávní legislativy ve Finsku by byla nejpokrokovější a nevyspělejší, nýbrž bud’to je zde historická příčina a jde o projev tradice, nebo se jedná o nějaký druh excesu mající jinou příčinu. 
Kupříkladu závodní kolektivní smlouva o pracovní době pro úsek výroby (lokální kolektivní smlouva) platná od 1. června 2018 mezi Závodním klubem odborového svazu IF Metall (odborový svaz KOVO) a společností Volvo Cars, pro technické zaměstnance, zavádí jako jeden z řady institutů osobní banku pracovní doby zaměstnance. Kolektivní smlouva předpokládá u zaměstnanců, kteří nevykonávají práci v nočních směnách, celkový počet 2080 pracovních hodin za rok s tím, že pracovní úvazek zaměstnance činí 43 hodin týdně. Tři hodiny z týdenního úvazku, označené jako více čas, nejsou považovány za přesčasovou práci. Důvodem je, že 3 hodiny a 27 minut týdně z odpracované pracovní doby (43 hodin) se převádí do osobní banky zaměstnance na jeho osobní konto. Kumulace pracovní doby na osobním kontu není časově omezena. Nároky zaměstnance se nepromlčují. V důsledku působení jiné z kolektivních smluv však zaměstnavatel může v říjnu každého kalendářního roku, přesahuje-li zůstatek zkumulovaných hodin zaměstnance více jak 250 , zredukovat počet až na 250 hodin spolu $\mathrm{s}$ tím, že zaměstnanci ve vztahu k přepočetným hodinám svědčí právo (a) na proplacení zkumulovaného přepočetného času, (b) na placené (náhradní) volno v rozsahu přepočetných hodin, (c) převedení hodin/finanční kompenzace do penzijního fondu zaměstnance. V této souvislosti lze jen doplnit, že tohoto práva zaměstnavatel od roku 2007 využil jen jedenkrát.

Kumulovanou pracovní dobu na osobním kontu je možné vybrat trojím způsobem. Zaměstnanec si může jednak vybrat placené pracovní volno v jím určeném rozsahu (včetně možné kombinace s jinak neplacenou dovolenou - finanční zajištění po dobu pracovního volna z titulu dovolené se poskytne z konta zaměstnance), jednak je možné v zaměstnancem určeném rozsahu poskytnout přímou finanční náhradu bez pracovního volna, jednak je možné peněžní prostředky odpovídající náhradě, kterou by zaměstnanec obdržel, převést do závodního penzijního fondu. Náhrada mzdy v době pracovního volna, stejně jako finanční kompenzace za „prodej“ pracovních hodin, se poskytuje ve výši průměrné mzdy zaměstnance $\mathrm{v}$ době čerpání/prodeje bez ohledu na to, o pracovní čas, z jakého období se jedná. To lze (z hlediska zaměstnance) hodnotit pozitivně, nebot' při dlouhodobé kumulaci bude hodina času připsaná na osobní konto v roce 2000 proplacena mzdou k okamžiku čerpání, tedy na př́klad v roce 2018, která bude zpravidla větší, při změně pozice atp. není vyloučeno, že dokonce násobně.

\section{VYBRANÉ OTÁZKY SKONČENÍ PRACOVNÍHO POMĚRU}

Jedním z pravidelných témat $\mathrm{v}$ diskusích o novelizaci pracovněprávních prredpisů je institutu, který se označuje jako „výpovéd” bez výpovědního důvodu“ nebo „výpověd” bez dưvodu“. Aktuálně připravovaná novela zákoníku práce (prozatím) tuto otázku neřeší. V minulosti se však v rámci různých návrhů tyto tendence objevily. Měly různou podobu a pravidelně trpěly různou mírou nekoncepčnosti.

$\mathrm{V}$ prvé řadě si lze jen velice těžko představit, že by $\mathrm{v}$ rámci zdejší právní kultury a kontinentálního systému práva, mj. v návaznosti na tradici relativně silné právní ochrany postavení zaměstnance a koncept sociálního státu obecně, mohla existovat skutečná výpověd’ z pracovního poměru ze strany zaměstnavatele bez uvedení důvodu, 
resp. bez skutečného materiálního důvodu, tedy shodný institut, který zákoník práce zná ve směru k zaměstnanci. Vyloučíme-li tuto možnost, nabízí se dvě situace, která lze vztáhnout pod shora uvedený pojem.

Bud'to se může jednat o institut vyplacení/vykoupení ze zaměstnání v pozici, kdy právní úprava nabízí zaměstnavateli možnost se zaměstnancem jednostranně rozvázat pracovní poměr bez specifikace kauzálního důvodu, kterou však podmiňuje vyplacením určité částky odchodného, jehož výše zpravidla představuje několikanásobek průměrného měsíčního výdělku zaměstnance; počet průměrných výdělků se může odvíjet mj. od doby trvání pracovního poměru zaměstnance k zaměstnavateli. Pro upřesnění lze doplnit, že vykoupením ze zaměstnání, resp. vyplacením ze zaměstnání může rozumět taktéž situaci, kdy je pracovní poměr (z jedné nebo z druhé strany) skončen jednostranným právním jednáním $\mathrm{s}$ výpovědní dobou, přičemž vypovězená strana pracovního poměru nemá zájem, aby pracovněprávní vztah přetrval po celou výpovědní dobu. Pro tyto př́ípady jí pak zákon nabízí možnost skončit pracovní poměr předčasně, tj. před uplynutím výpovědní doby, při zaplacení předepsané peněžité částky.

Vedle toho (avšak nepřesně) bývá za druhou variantou výpovědi „,bez důvodu“, která se mj. objevila $\mathrm{v}$ jednom $\mathrm{z}$ pozměňovacích návrhů $\mathrm{k}$ loňské „koncepční“ novele zákoníku práce, označována výpověd' z pracovního poměru ze strany zaměstnavatele při naplnění obecné skutkové podstaty/výpovědního důvodu formulovaného zhruba tak, že „po zaměstnavateli již nelze spravedlivě požadovat, aby zaměstnance dále zaměstnáva$l^{\prime \prime} .{ }^{21}$ Konkrétně, předmětem pozměňovacího návrhu Zbyňka Stanjury k loňské novele zákoníku práce bylo doplnění ust. § 52 ZPr ve smyslu, že mimo již existující důvody by zaměstnavatel mohl se zaměstnancem skončit pracovní poměr výpovědí také tehdy, nebylo-li by již po zaměstnavateli spravedlivé požadovat, aby zaměstnance nadále zaměstnával; jde de facto o přepis pravidelně se objevující formule v rozhodnutí Nejvyššího soudu České republiky, která se vztahuje ke skončení pracovního poměru pro porušení pracovní kázně (povinnosti vyplývající z právních předpisů vztahujících se k zaměstnancem vykonávané práci).

Je zjevné, že prezentace takového řešení jako skončení pracovního poměru „bez důvodu“ je pouze politickou proklamací, nebot' nemá-li být po zaměstnavateli spravedlivé požadovat, aby zaměstnance dále zaměstnával, musí existovat legální a legitimní důvod (převažující zájem na stabilitě pracovního poměru). Legálním a legitimním důvodem může být, že zaměstnanec není zdravotně způsobilý k práci, či že zaměstnavatel ruší provoz, nebo jej přesouvá mimo místo výkonu práce zaměstnance, anebo že v důsledku technologických či jiných změn organizační povahy odpadne potřeba zaměstnancovi práce, př́p. že zaměstnanec nesplňuje předpoklady plynoucí z právních předpisů ve vztahu $\mathrm{k}$ vykonávané práci, či snad že zaměstnanec porušuje své pracovněprávní povinnosti $\mathrm{v}$ určité míře a intenzitě. Vezmeme-li v patrnost, že právní úprava $\mathrm{v}$ této části představuje mj. částečně provedení práva svobodnou volbu povolání a současně, že je zde (mj. i celospolečenský) zájem na určité míře stability pracovněprávních vztahů,

21 Předmětnou úpravu, spolu s několika dalšími souvisejícími s právní úpravou skončení pracovního poměru, navrhl poslanec Zbyněk Stanjura dne 1. března 2017 při projednávání návrhu zákona ve druhém čtení. 
pak těžko budeme hledat jiný důvodem mimo právě uvedené, tedy výpovědní důvody, které již zákon zná.

I přes uvedené je zde však důvod se naznačenou konstrukcí, tedy právem zaměstnavatele se zaměstnancem skončit pracovní poměr výpovědí v momentě, kdy po zaměstnavateli nelze spravedlivě požadovat, aby zaměstnance dále zaměstnával, zabývat. Důvodem je snad až určitá obřadnost, kterou stávající právní úprava předpokládá pro platnost skončení pracovního poměru - zákonný důvod, specifikace důvodu, využití důvodu $\mathrm{v}$ zákonné lhůtě, $\mathrm{v}$ některých př́padech předchozí písemné upozornění konkrétního obsahu atd. ${ }^{22}$ V kontextu judikatury Nejvyššího soudu České republiky nikoli výjimečně bývá i přes legitimní důvod pro skončení pracovního poměru právní jednání neplatné kvůli nenaplnění některé z předepsaných formalit.

V tomto kontextu se tudíž zdá vhodnějši úprava, kterou zná kupř́ikladu švédský zákon č. 1982: 80 SFS o ochraně zaměstnanců..$^{23}$ Zákon předpokládá kauzální důvody (§ 9) pouze $\mathrm{v}$ případě, kdy dochází $\mathrm{k}$ okamžitému zrušení pracovního poměru. Jinak platí, že pracovní poměr je možné vypovědět, existuje-li objektivní a legitimní důvod, aniž by se konkrétně stanovilo, co takový objektivní důvod znamená; vyjma nadbytečnosti se o každém skončení z objektivního důvodu jedná s odborovou organizací. V kolektivní smlouvě lze důvody př́ípadně taktéž specifikovat.

Určitá volnost $\mathrm{v}$ tomto směru je kompenzována délkou výpovědní doby. Minimální délka výpovědní doby činí 1 měsíc. $\mathrm{V}$ závislosti na době trvání pracovního poměru k zaměstnavateli se však prodlužuje, když při zaměstnání trvajícím

- nejméně 2 roky a ne více jak 4 roky činí 2 měsíce;

- nejméně 4 roky a ne více jak 6 let činí 3 měsíce;

- nejméně 6 let a ne více jak 8 let činí 4 měsíce;

- nejméně 8 let a ne více jak 10 let činí 5 měsícư;

- nejméně na 10 let činí 6 měsíce.

Z hlediska zdejšího pojímání není bez zajímavosti, že během výpovědní doby může zaměstnanec vykonávat práci pro jiného zaměstnavatele. Odměna/náhrada od původního zaměstnavatele se přitom snižuje o to, co zaměstnanec utrží při práci pro jiného zaměstnavatele $\mathrm{v}$ rámci výpovědní doby.

Právní úprava obsažená v ZoOZ však může být inspirativní i v jiných ohledech. Jde-li o skončení pracovního poměru, zná zákon kupř́kladu mechanismus, jímž se určuje, je-li více zaměstnanců nadbytečných, ten, se kterým bude skončen pracovní poměr. Do počtu 10 zaměstnanců u zaměstnavatele si může zaměstnavatel volit sám. Jinak, není-li ujednáno něco jiného s odborovou organizací, je rozhodný den nástupu do zaměstnání nadbytečný je předně ten, kdo nastoupil nejpozději.

Zákon zná taktéž nabídkovou povinnost jak při skončení pracovního poměru, tak v době (až 9 měsíců) po skončení pracovního poměru (projeví-li zaměstnanec při skončení pracovního poměru zájem o pozdější předpokládání nabídek pracovního uplatně-

$22 \mathrm{~K}$ tomuto srov. MORÁVEK, J. Skončení pracovního poměru - mancipace v pracovním právu? In: BĚLOVSKÝ, P. (ed.). Caro amico - 60 kapitol pro Michala Skřejpka aneb Římské právo napříc staletími. Praha: Auditorium. 2017.

23 Dále jen $\mathrm{ZoOZ}$. 
ní). V př́ípadě pracovních poměrů na dobu určitou a sezónních prací se lhůta obnovuje po každém skončení pracovního poměru.

Právní úprava se však liší i v jiných aspektech. Kupř́ikladu dle ust. § 6 ZoOZ je předepsána délka zkušební doby na 6 měsíců. Ustanovení $\S 5$ a $\S 5$ upravuje pracovní poměry na dobu určitou, přičemž nepředepisuje žádný maximální počet opakování či maximální délku trvání pracovního poměru na dobu určitou. Stanoví nicméně podmínky, za kterých se pracovní poměr na dobu určitou přerodí v pracovní poměr na dobu neurčitou.

Z hlediska zdejší právní kultury lze nicméně v zákoně identifikovat i momenty, které jsou zjevně nekompatibilní a nepoužitelné, jako je zvláštní úprava pro zaměstnance starší 67 let, tedy pro zaměstnance důchodového věku; u těchto zaměstnanců kupříkladu nedochází $\mathrm{k}$ automatickému přerodu pracovního poměru z doby určité na dobu neurčitou atp.

Nejsou to však jen délka výpovědní doby, vykoupení ze zaměstnání a méně formální nároky na právní jednání, jímž se pracovní poměr končí. Podobně by bylo možné v kontextu aplikační praxe zejména vyšších soudů, které v drtivé většině př́ípadů rozhodují pouze podle listin/obsahu spisu, aniž by měly kontext skutečného vztahu stran pracovního poměru a učinili si (i přes formální podklad tvrzení) představu o věrohodnosti účastníků ř́zení, stejně tak jako v kontextu obecné tendence soudů spočívající v zaměřování se primárně na formální aspekt věci, aniž by byl reflektován konečný a primární účel práva, jímž je dosažení spravedlnosti, formulovat závěr, že zdejší právní úpravě schází výslovné zakotvení institutu dodatečného (sociálního) ospravedlnění výpovědi/ skončení pracovního poměru, který zná např́íklad německá právní úprava. ${ }^{24}$

Konkrétněji, právní úprava Spolkové republiky Německo v kontextu principu spravedlnosti, jako konečného účelu objektivního práva, a zásady zákazu zneužití objektivního práva, vychází z předpokladu, že bude-li po skončení pracovního poměru prokázán důvod/skutek (existující v době trvání pracovního poměru), který by jinak mohl ospravedlnit skončení pracovního poměru, je třeba $\mathrm{k}$ němu přihlédnout $\mathrm{v}$ př́padném sporu zaměstnance a zaměstnavatele o platnosti/neplatnosti právního jednání, jímž se pracovní poměr skončil. Důvodem je mj. skutečnost, že by nedávalo dobrý smysl, aby kvůli nejistotě stran platnosti skončení pracovního poměru, které je předmětem soudního přezkumu, byl zaměstnavatel zbaven práva skončit se zaměstnancem pracovní poměr $\mathrm{z}$ tohoto dodatečného důvodu.

Podstatou institutu je tzv. sociální ospravedlnění skončení pracovního poměru (výpovědi) - zaměstnavatel má mít právo se zaměstnancem skončit pracovní poměr tehdy, je-li to s přihlédnutím ke všem okolnostem známým při projevu vůle směřujícího ke skončení pracovního poměru, stejně tak jako ke všem okolnostem, které vyjdou dodatečně najevo a podporují záměr zaměstnavateli, legitimní.

Německá právní úprava (viz zejména Kündigungsschutzgesetz a Betriebsverfassungsgesetz) tak umožňuje v soudním sporu zaměstnance a zaměstnavatele zohlednit i důvod pro skončení pracovního poměru existující v době skončení pracovního pomě-

24 Srov. například BADER, P. - ETZEL, G. et al. Gemeinschaftskommentar zum Kündigungsschutzgesetz und zu sonstigen kündigungsschutzrechtlichen Vorschriften. 7. Aufl. München: Luchterhand, 2004, LVIII, 3298 s. p. ISBN 3-472-05773-4, s. 83-84. 
ru, aniž by o něm zaměstnavatel skutečně věděl. Podstatnou je, v návaznosti na konečný účel objektivního práva, jak ve zdejším právním prostředí (právním řádu), tak v právním řádu Německa, sociální ospravedlnitelnost skončení pracovního poměru (spravedlnost/legitimita skončení pracovního poměru) - při rozhodování o platnosti skončení pracovního poměru, byla-li již projevena vůle zaměstnavatele směřující ke skončení pracovního poměru, je rozhodný objektivní stav, tedy objektivní existence důvodů pro skončení pracovního poměru, nikoliv subjektivní vědomost na straně zaměstnavatele.

Jinak řečeno, důležité pro posouzení, zda je skončení pracovního poměru sociálně ospravedlnitelné (po právu), je v tomto kontextu objektivní existence výpovědního důvodu v době podání výpovědi, nikoliv subjektivní vědomost zaměstnavatele. V důsledku toho může tudíž být důvod výpovědi ještě i de facto dodatečně změněn - skončení pracovního poměru může být kvalifikováno jako platné, byt' by původní důvod zahrnutý do právního jednání zaměstnavatele sám o sobě neobstál, pokud dodatečně v řízení zjištěný a prokázaný důvod, který není do právního jednání zahrnut, nicméně existoval v době trvání pracovního poměru, skončení pracovního poměru odůvodňuje (takový důvod je dostatečný), a to i kdyby se o něm zaměstnavatel dozvěděl až po skončení pracovního poměru (tř̌eba i až v průběhu ř́zení).

\section{ZÁVĚR}

Stávající právní úprava pracovněprávních vztahů v širokém smyslu slova má několik slabých momentů. Ty dle všeho plynou mj. z nedostatečné reflexe hospodár̆ského a technického vývoje, což má za důsledek mj. jistou zkostnatělost úpravy, která neumožňuje reagovat na nové potřeby a trendy aplikační praxe. Uvedené platí přirozeně i pro legislativu ve smyslu tvorby zákonodárství, kde, zdá se, schází potřebný kontakt s praxí. Tento stav, spolu s v podstatě zcela disfunkční vnitřní kontrolou a s velice slabou vnější kontrolou dodržování právních pravidel, ${ }^{25,26}$ jejíž příčina spočívá v nedostatečné personální a odborné vybavenosti kontrolních orgán, zejména inspektorátů práce, to vše podpořeno nákladností a složitostí uplatnění práv soudní cestou (včetně délky řízení), ${ }^{27}$

$25 \mathrm{~K}$ počtu provedených kontrol v jednotlivých oblastech ze strany inspektorátů práce viz výroční právy Státního úřadu inspekce práce (viz <http://www.suip.cz/rocni-zpravy/>).

26 Pro právě uvedené závěry svědčí statistické údaje z výročních zpráv Státního úřadu inspekce práce, jde-li kupř́kladu o kontrolu bezpečnosti a ochrany zdraví na staveništích, kde jsou poměrně komplexní a rozsáhlé požadavky plynoucí z právních předpisů na zajištění bezpečnosti a ochrany zdraví při práci (viz <http:// www.suip.cz/rocni-zpravy/>). Úhrnný počet kontrol vykonaných inspektoráty práce za rok čítá řádově desetitisíce př́padů (v roce 2017 se jednalo kupříkladu o 24.945 kontrol, v roce 2016 pak o 26.620 kontrol - viz tiskové zprávy na stránkách Státního úřadu inspekce práce - viz http://www.suip.cz/pro-media /tiskove-zpravy/) z nichž však na oblast bezpečnosti a ochrany zdraví na staveništích bylo zaměřeno: v roce 2012 celkem 1.386; v roce 2013 celkem 1.233; v roce 2014 celkem 1.159; v roce 2015 celkem 987; v roce 2016 celkem 875 ; v roce 2017 celkem 785 .

27 Z průzkumu provedeného v roce 2016 u všech okresních a obvodních soudů vyplynulo, že celkový nápad pracovněprávních sporů na všechny okresní soudy byl 4.246 věcí v roce $2012,4.431$ věcí v roce 2013 , 4.913 věcí v roce 2014, 3.647 věcí v roce 2015 a 1.336 věcí do 31. května 2016. Srov. PICHRT, J. - ŠTEFKO, M. - MORÁVEK, J. Analýza alternativních způsobů řešení sporů v pracovněprávních vztazích. Praha: Wolters Kluwer, 2016. s. 223. V roce 1988 přitom dle dostupných informací čítal celkový roční nápad pracovněprávních sporů 26.466 př́ípadů a tvořil $14,9 \%$ z celkového soudního nápadu. Aktuálně 
nikoli nevýznamně potlačuje platnost právní regulace. Kupř́ikladu předpisy o bezpečnosti a ochraně zdraví při práci, ale i pravidla o pracovní době atp., v mnoha př́padech pro zaměstnavatele představují jen bezobsažné formule, jimž není třeba věnovat pozornost a jejich reálná váha činí asi tolik, kolik je hmotnost papíru, na kterém jsou zapsány.

Nalézt odpovídající řešení není lehké. S ohledem na významné odlišnosti v jednotlivých způsobech výkonu práce a provozech, s ohledem na mnohdy diametrálně odlišné potřeby, se nabízí uvažovat o základní rámcové regulaci na úrovni právních předpisů (primárně zákona) s tím, že v dílčích podrobnostech budou pravidla dotvořena na podnikové úrovni dohodou zaměstnavatele a zaměstnanců, resp. přesněji zástupců zaměstnanců (odborů) s přihlédnutím k potřebám př́íslušného provozu.

Aktivní působení zaměstnanců, resp. zástupců zaměstnanců na podnikové úrovni by s sebou z povahy věci neslo i posílení vnitřní kontroly, a tedy zvýšení úrovně platnosti zákonné regulace. Tento aspekt by stejně tak podpořilo jednak personální posílení (zejména z hlediska odbornosti) kontrolních orgánů a jednak dle všeho specializované pracovní soudnictví či alespoň pevná specializace soudce obdobná správnímu úseku, kdy by senát byl tvořen vedle předsedy senátu, jímž by byl soudce z povolání, nejméně jedním přísedícím vybraným z nominantů zaměstnavatelů a jedním př́sedícím vybraným z nominantů zaměstnanců. Tento systém ostatně znal již zákon č. 131/1931 Sb. a n., o pracovních soudech, dle jehož ust. § 16 ,,pracovní soud jedná a rozhoduje v senátech složených z prèedsedy nebo jeho náměstka a ze dvou prísedících, z nichž jeden jest ze skupiny zaměstnavatelů, druhý ze skupiny zaměstnancü. " Specializace, která by mohla přinést i zrychlení rrízení, však sama o sobě nestačí. Pro posílení platnosti právního řádu je stejně tak potřebná a možná potřebnější účast zástupců zaměstnanců v rámci ř́zení, konkrétně odborná podpora a pomoc v podobě zastupování. ${ }^{28}$ Stejně tak se nabízí úvaha, zda či v jaké míře by mělo být řízení v pracovních věcech podrobeno poplatkové povinnosti.

Z uvedeného se podává, že zásadní je aktivní (nikoli aktivistické) zapojení zástupců zaměstnanců (odborů) na odpovídající odborné úrovni. To se však prozatím zdá jako těžko dosažitelný cíl.

Stávající postavení odborů v České republice, včetně nízké odborové organizovanosti (přibližně $33 \%$ ), ${ }^{29}$ nezájmu o účast $\mathrm{v}$ odborech a o jejich činnost, plyne z řady faktorů.

Jedním z nejpodstatnějších je bezesporu určitá pachut', kterou nese reminiscence předlistopadové doby, kdy (de facto povinná) odborová organizovanost v Revolučním

pritom z celkového ročního soudního nápadu tvoří pracovněprávní spory již dlouhodobě (nejméně od roku 2011) méně jak $1 \%$. Tamtéž s. 6-7.

28 Z průzkumu provedeného $\mathrm{v}$ roce $2016 \mathrm{u}$ všech okresních a obvodních soudů vyplynulo, že odborové organizace zastupovali z celkového nápadu (viz předchozí poznámka) v následujícím počtu př́ípadů: rok 20124 prŕípady, rok 20133 př́ípady, rok 20145 př́ípadů, rok 20159 př́ípadů, za rok 2016 do 31. května 2016 v 1 př́ípadě. PICHRT, J. - ŠTEFKO - M., MORÁVEK, J. Analýza alternativních zpuisobů řešení sporů v pracovněprávnich vztazích. Praha: Wolters Kluwer, 2016. s. 200.

29 Srov. Bognárová, V. In: BĚLINA, M. - PICHRT, J. a kol. Pracovní právo. 7. doplněné a podstatně přepracované vydání. Praha: C. H. Beck, 2017, s. 386. 
odborovém hnutí (ROH) dosahovala bezmála $100 \%{ }^{30}$ Odmítání předlistopadových schémat, jistá dezorientace ve svobodném světě, rozvoj soukromého podnikání a malých podniků spolu se zánikem řady velkých průmyslových podniků, to vše vedlo k přetržení (byt'v době komunistické nesvobody pokřivené) zdejší tradice relativně odborové organizovanosti. Odboroví předáci (nejen té doby) dle všeho nesprávně vyhodnotili situaci. Místo vybudování odpovídajícího zázemí, tj. zejména získání potřebného lidského kapitálu, který bude schopen flexibilně reagovat a poskytovat podporu a moc $\mathrm{v}$ individuálních prŕípadech, práce se zaměstnanci v podniku a řešení jejich každodenních problémů, včetně jejich zastupování ve sporech se zaměstnavatelem, se soustředili a soustředí spiše na makroekonomické otázky a to způsobem nikoli nepodobným tomu, jak to činí politické strany a hnutí; i když je samozřejmě možná náhodou, že Richard Falbr, první předseda ČMKOS, se stal nejdříve senátorem a posléze poslancem Evropského parlamentu, že druhý předseda ČMKOS, Milan Štěch, se stal senátorem, místopředsedou Senátu a následně i předsedou Senátu Parlamentu České republiky, že třetí Předseda ČMKOS se stal poslancem Parlamentu České republiky, a že stávající předseda jmenovaného svazu si (zdá se) brousí zuby na post nejvyšší.

Ze zkušenosti lze soudit, že činnost odborových centrál má své těžiště zejména v rovině legislativy a tripartitního vyjednávání. Rovina „běžného podnikového bojiště““ je (pravděpodobně kvůli nedostatku personálních zdrojů) v pozadí. Jak jinak si vysvětlit, že odborové svazy a centrály poskytují podporu nově vznikajícím organizacím větší měrou pouze při založení, avšak v další činnosti, včetně kolektivního vyjednávání, je nechávají svému osudu. Možná je však taková představa zkreslená, nebot' závěr staví pouze na několika osobních zkušenostech. Co je však prokazatelné a hovoří pro naznačený závěr, je statistika zpracovaná v projektu Analýza alternativních způsobů řešení sporů $\mathrm{v}$ pracovněprávních vztazích. $Z$ průzkumu provedeného $\mathrm{v}$ roce $2016 \mathrm{u}$ všech okresních a obvodních soudů vyplynulo, že odborové organizace zastupovali zaměstnance z celkového nápadu pracovněprávních sporů (viz poznámka pod čarou č. 27) v následujícím počtu př́padů: rok 20124 prrípady, rok 20133 př́pady, rok 20145 případů, rok 20159 prrípadů, za rok 2016 do 31 . května 2016 v 1 prrípadě. ${ }^{31}$

Ani aktivní, efektivní a kvalifikovaná činnost odborových organizací samozřejmě není zárukou fungujícího a platného právního řádu, resp. právní regulace pracovněprávních vztahů. Může však významně přispět ke kvalitě právního prostředí, významně napomáhat a garantovat práva zaměstnanců - řada zaměstnanců nemá představu, jaká práva jim náleží a jak by je mohli uplatnit, tzn. již samotná informace o právech a způsobem jejich uplatnění je pozitivní aspekt, dalším navazujícím krokem je aktivní zastupování zaměstnanců při vyjednávání se zaměstnavatelem, jde-li o hospodářské a sociální zájmy, jakož i ve sporech o individuální nároky.

Cesta $\mathrm{k}$ takovému stavu, pokud by byla nastoupena, by byla dlouhá a musela by být nutně pozvolná.

30 Srov. GALVAS, M. K problematice reprezentace zaměstnanců v pracovním právu ČR. In: GREGOROVÁ, Z. (rec.). Sborník př́spěvků z mezinárodní vědecké konference Pracovní právo 2011 na téma Sociální dialog. Acta Universitatis Brunensis. Iuridica. sv. 406. Brno: Masarykova Univerzita. 2011. s. 12.

31 Viz PICHRT, J. - ŠTEFKO, M. - MORÁVEK, J. Analýza alternativnich způsobů řešení sporů v pracovněprávních vztazich. Praha: Wolters Kluwer, 2016, s. 200. 
Základem musí být podniková úroveň. Aby se mohla podniková úroveň stát stavebním kamenem, musí být činnost na úrovni podniku kvalifikovaná a efektivní a zástupci zaměstnanců musí být ze strany zaměstnavatele bráni vážně. Aby tomu tak bylo, musí zástupci zaměstnanců reprezentovat významný počet zaměstnanců v podniku - to jim jednak dává váhu a jednak jim umožňuje kumulovat potřebné finanční zdroje a lidský kapitál pro efektivní a kvalifikovanou činnost. Aby mělo zastupování a vyjednávání zástupců zaměstnanců a zaměstnavatele smysl, musí být o čem jednat, tedy právní úprava musí dávat odpovídající možnosti prostřednictvím dohody jmenovaných potřebným směrem a v potřebné míre posunout základní zákonná pravidla (ideálně do stavu, kdy převládá pocit win-win). Jinak řečeno, potřebná je určitá míra flexibility, která umožní po vzájemné dohodě překonat zákonnou úpravu, která by pro tyto př́ípady měla mít pouze nezbytné tvrdé kogentní jádro „kolíkující hrací pole“. Uvolňování právní regulace až do pozice uvedené $\mathrm{v}$ předchozí větě by nutně muselo být pozvolné dle míry kvalifikovanosti a kvality zástupců zaměstnanců, nebot' konečná podobě dispozitivní úpravy s minimálním tvrdým jádrem odpovídá stavu kvalifikovaných, kvalitních a efektivních zástupců zaměstnanců podpořených veřejnosprávní kontrolou a fungujícím soudním systémem umožňujícím v rozumném časovém horizontu se domoci svých individuálních nároků; jedno (veřejnosprávní kontrola) i druhé (soudní ochrana), pokud hovoříme o zajištění odpovídající funkčnosti systému a skutečné platnosti právního řádu, taktéž nemohou zůstat bez změny, zejména jde-li o personální vybavenost.

Těžko nahraditelným momentem určujícím míru odborové organizovanosti je tradice. Ta však, jak bylo uvedeno shora, byla přetržena. Cestou, jak jinak motivovat $\mathrm{k}$ většímu zájmu o své zájmy a práva, který může vést $\mathrm{k}$ sdružování do spolků, resp. odborových organizací, je flexibilita navázaná právě na sdružovací právo. Žádoucího stavu by bylo možné docílit změnou zdejšího modelu při určené inspiraci ve švédské právní úpravě.

Konkrétněji, ve Švédsku je možné, aby na jednom pracovišti působilo více odborových organizací a bylo sjednáno více kolektivních smluv, přičemž např́ílad dle $\S 2$ ZoRD či § 2a ZoD platí, že kolektivní smlouva se uplatní na zaměstnance, kteří jsou odborově organizováni v odborové organizaci, která kolektivní smlouvu sjednala, přičemž záleží na rozhodnutí zaměstnavatele, zda obsah takové kolektivní smlouvy uplatní i vůči ostatním zaměstnancům. Takové legislativní opatření by umožnilo eliminovat stávající černé pasažéry, tedy zaměstnance, kteří těží z výhod kolektivní smlouvy ujednané na pracovišti odborovou organizací, aniž by byli jejími členy a jakkoli aktivně se zajímali a zasloužili o ochranu svých hospodářských a sociálních zájmů u zaměstnavatele.

Naznačené řešení není jistě jediné možné. Jsou i jiná. Některá mohou být i lepší. Změny zažitých paradigmat tohoto charakteru si žádají čas a stabilitu. At' již bude zvoleno kteréhokoli z nich, bude třeba „držet směr“ a při prvním náznaku problémů či př̀i změně politické reprezentace ihned neměnit cíle a směřování. Možné jsou jen drobné korekce kurzu.

JUDr. Jakub Morávek, Ph.D.

Právnická fakulta Univerzity Karlovy moravek@prf.cuni.cz 


\title{
ZERO HOURS CONTRACTS
}

\author{
JAN PICHRT*
}

\begin{abstract}
Zero hours contracts
The article focuses on comparing details and differences (Zero hours contracts) in British labour law with the performance of work on the basis of Czech agreements on out-of-work contracts and influence these non-standard labour relations on employment policy and possible negative effects on labour-law securities.
\end{abstract}

Keywords: Zero hours contracts; exclusivity clause; labour-law securities

Klíčová slova: Zero hours contracts; doložka exkluzivity; pracovněprávní jistoty

DOI: $10.14712 / 23366478.2019 .7$

\section{I. ÚVODEM K ATYPICKÝM PRACOVNĚPRÁVNÍM VZTAHŮM A K PODKOPÁVÁNÍ PILÍŘŮ PRACOVNÍHO PRÁVA}

Téměř ve všech zemích, které lze podřadit pod skupinu „rozvinutých ekonomik“, přitahují tzv. atypické pracovněprávní vztahy trvale pozornost právní teorie ${ }^{1}$ i praxe. Pokud jde o oblast právní teorie, je tomu tak i proto, že většina autorù věnujících se tomuto tématu vnímá určité dilema, které stále pestřejší množina těchto vztahů přináší. Na straně jedné je nepochybné, že technologický pokrok a s ním související změny ve způsobu výkonu práce v mnohých profesích (včetně „mizeni'“ některých druhů práce a „objevování“ nových profesí) vedou v některých př́padech k potřebě reflektovat tyto změny i určitou modifikací „klasických“ právních vztahů, ve kterých je závislá práce konána. Na straně druhé je stále patrnější, že ono „přizpůsobení se novým potřebám a trendům“, které je (částečně oprávněně) dáváno do korelace s vytvářením nových pracovních míst či se zaměstnaností těch, kteří by se v „klasickém uspořádáni““

* Autor je vedoucím katedry pracovního práva a práva sociálního zabezpečení Právnické fakulty Univerzity Karlovy (Praha), hlavním řešitelem Výzkumného centra UNCE/HUM/034 „Závislá práce v 21. století otázky a výzvy“, předsedou České společnosti pro pracovní právo a právo sociálního zabezpečení, členem Komise pro pracovní právo a sociální věci Legislativní rady vlády ČR, advokátem a rozhodcem zapsaným na listině rozhodců Rozhodčího soudu při HK ČR a AK ČR.

1 I na Právnické fakultě UK se této problematice dlouhodobě věnujeme, srov. např. PICHRT, J. - MORÁVEK, J. (eds.). Atypická zaměstnávání - cesta k vyšši zaměstnanosti? Praha: Wolters Kluwer, 2015, 336 s. ISBN 978-80-7478-975-5. 
do pracovního procesu zapojit nemohli, je mnohými aktéry teorie i praxe obratně využíváno $\mathrm{k}$ postupné destrukci pracovního práva (minimálně v jeho evropském a sociálním pojetí). Frázemi o nutnosti „reflektovat technologický pokrok“ jsou občas zakrývány nejrůznější snahy zaměstnavatelů „vyvádět“ výkon mnohých (dosud závislých) prací $\mathrm{z}$ „ochrany“ pracovního práva do oblasti „odběratelsko-dodavatelských“ vztahů a jiné postupy přispívající $\mathrm{k}$ postupné erozi piliŕr̆ů, na kterých pracovní právo dosud stojí, a doufejme, že i do budoucna stát bude.

Český právní rád (stejně jako např. právní rád Spojeného království Velké Británie a Severního Irska) neobsahuje vymezení pojmu atypická zaměstnání. Typické pro atypická zaměstnání je navíc to, že jejich okruh není vnímán ani doktrinálně zcela jednotně. Není to překvapující, vezmeme-li v úvahu, že ani obsah jejich ,jazykového protipólu“ - tedy „typického zaměstnáni“ - nemusí být vnímán zcela jednotně².

Část teorie považuje za „typické zaměstnáni““ (či možná „nejvíce žádoucí) pracovněprávní vztah sjednaný na plný úvazek a na dobu neurčitou (někteří autoři $\mathrm{k}$ tomu připojují atribut konání práce na pracovišti zaměstnavatele). $Z$ výše uvedených znaků je pak zřejmé, že výkladem a contrario vymezená množina atypických pracovních poměrů by byla velmi široká3 .

Přes různost pohledů na šíri množiny atypických pracovněprávních vztahů se většina teorie (evropské) shoduje v tom, že mezi ně patří pracovní poměry na dobu určitou a pracovněprávní vztahy realizované $\mathrm{v}$ rámci agenturního zaměstnávání, $\mathrm{v}$ širším slova smyslu pak i práce na částečný úvazek. Podíváme-li se však do prací věnujících se pracovnímu právu ve Velké Británii, zjistíme, že autoři do této skupiny podřazují i tzv. zero hours contracts ${ }^{4}$ (které bývají někdy označované též jako „,nil-hours contracts" ${ }^{\text {“5 }}$ ), a současně někteř́ neopomenou zdůraznit, že právě s výjimkou naposled uvedeného pracovněprávního vztahu je právní úprava atypických pracovněprávních vztahů ovlivněna právem EU a reflektuje koncept „flexicurity“. 6 To jistě vzbudí pozornost každého badatele; pojd’me se tedy blíže podívat na tento, unijními koncepty nedotčený, právní instrument.

2 Bliže k problematice atypických zaměstnání srov. též PICHRT, J. Několik úvah k budoucímu směřování vývoje atypických zaměstnání. In: Liberalizácia právnej regulácie pracovných vzt'ahov v podmienkach globalizácie. Zborník príspevkov z medzinárodnej vedeckej konferencie „Právo ako zjednocovateí Európy - veda a prax“, slovenská čast', s. 183-189. Bratislava: Univerzita Komenského, PF, 2011.

3 Srov. PICHRT, J. Některé aspekty atypických zaměstnání a zaměstnanosti z pohledu individuálního i kolektivního pracovního práva. In: PICHRT, J. - MORÁVEK, J. (eds.). Atypická zaměstnávání-cesta k vyšši zaměstnanosti? Praha: Wolters Kluwer, 2015, s. 11 a násl. Shodné vymezení atypických pracovněprávních vztahů jako shora srov. DAVIS, A. C. L. Employment Law, Pearson Education Limited, 2015, ISBN 978-1-4082-6360, s. 120.

4 V anglické odborné literatuře se lze běžně setkat jak s variantou s pomlčkou (,zero-hours contracts“) tak s variantou bez pomlčky (,,zero hours contracts"). Někteří autoři používají jako synonymum též tvar „zero-hours work“ (též s pomlčkou i bez pomlčky) či i jen zkrácenou formu ,zero hours“; v následujícím textu bude nadále používán především tvar ,zero hours contract(s)“.

5 Srov. NAPIER, B. - SMITH, I. S. - EADY, J. - MCMULLEN, J. - BRENNAN, T. Harvey on Industrial Relations and Employment Law (HIREL). LexisNexis UK. ISBN/ISSN: 9780406048110. Issue 259, 57.01.

6 Např. DAVIS, A. C. L. Employment Law, Pearson Education Limited, ISBN 978-1-4082-6360, 2015, s. 120. 


\section{ZERO HOURS CONTRACTS}

Pro stručnou charakteristiku úvodem je možné uvést, že označení „,zero hours contracts“ je v oblasti pracovněprávních vztahů ve Spojeném království obecně užíváno k označení takových smluv, které nezaručují minimální objem odpracované doby, resp. ve kterých není garantován minimální hodinový rozsah přidělované/konané práce. Množství takových smluv v posledních letech strmě roste $\mathrm{v}$ oblastech jako pečovatelství, služby v pohostinství apod.7 Ze smluv, které bývají dosud často označovány jako př́ležitostné ${ }^{8}$ (nebo „přerušované“ či , podle potřeby“"9), se stávají smlouvy stále více oblíbené mezi zaměstnavateli (což není ve své podstatě překvapivé s ohledem na výhody /či spíše úlevy v podobě neposkytování některých plnění/, které zaměstnavatelům skýtají oproti standardním zaměstnaneckým vztahům - viz níže).

Mnozí britští autoři také upozorňovali, že shora zmíněná terminologie není v právu pevně ukotvena a zmíněná označení mohou být použivána pro více různých typů uspořádání pracovněprávních vztahů..$^{10}$ Bylo též poukazováno, na to, že z pohledu common law se jedná v podstatě o ekonomickou, nikoliv právní kategorii ${ }^{11}$. I materiál, který britská vláda připravila jako podklad ke konzultacím o možné budoucí právní úpravě používání ,zero hours contracts“, v roce 2013 uváděl: „Neexistuje legální definice ,zero hours contracts 'v národním právu. Obecně platí, že , zero hours contracts ' je zaměstnanecká smlouva, ve které zaměstnavatel nezaručuje jednotlivci práci a jednotlivec není povinen príimout žádnou nabídnutou práci. "12 Je zde na místě podotknou, že redukcí smluvních typů, které lze zahrnout pod ,zero hours contracts“ na zaměstnaneckou smlouvu (an employment contract), „si to“ vládní materiál velmi (na úkor přesnosti) zjednodušil, jak bude i dále rozebráno. Ilustrativní je vládním materiálem uvedený př́iklad vzorové klauzule činící ze smlouvy smlouvu typu ,zero hours contracts“: „Společnost nemá nikdy povinnost poskytnout vám jakoukoliv práci, vy nemáte povinnost prijimout jakoukoli práci kdykoliv Vám nabídnutou společností."13

Postupně rostoucí obliba či spíše četnost užívání smluv zařaditelných pod „,zero hours contracts" ukázala ve Spojeném království na mnohé problémy s nimi spojené.

Především to byl sám fakt nejistoty ohledně ,zaměstnaneckého“ statusu pracovníků takové práce konající a $\mathrm{z}$ toho plynoucí nejistota stran jejich zaměstnaneckých práv, jakož i fakt, že takoví zaměstnanci nemají zaručenu žádnou minimální úroveň pravidelného př́ijmu.

7 Srov. LEWIS, T. Employment law: an adviser's handbook. 12th edition. Legal Action Group. ISBN 9781908407948, 2017, s. 20.

8 Mezi „casual contracts“ jsou tyto smlouvy zahrnuty např. v publikaci EMIR, A. Law of Employment, Oxford University Press, 20th Edition, ISBN 978-0-19-881484-9, 2018, s. 78.

9 Intermittent or as required - srov. DAVIS, A. C. L. Employment Law, Pearson Education Limited, ISBN 978-1-4082-6360, 2015, s. 120.

10 Srov. DAVIS (viz shora) a shodně s ním např. LEWIS, T. (viz shora).

11 Srov. HIREL. Issue 259, 57.01.

12 Department for Business, Innovation and Skills. Consultation: zero hours employment contracts, 2013, dostupné online na: <https://assets.publishing.service.gov.uk/government/uploads/system/uploads /attachment_data/file/267634/bis-13-1275-zero-hours-employment-contracts-FINAL.pdf>.

13 „The Company is under no obligation to provide work to you at any time and you are under no obligation to accept any work offered by the Company at any time. "Tamtéž. 
K problému negarantovaného prŕíjmu Davis ${ }^{14}$ uvádí: „Jestliže se zaměstnavatel nezavázal k žádnému určitému objemu práce, může se individuálni výdělek lišit od týdne $k$ týdnu a mũže být v některém týdnu nulový. "15 a dodává, že to jednotlivcům v takové situaci nejen ztěžuje osobní finanční hospodaření, ale může také způsobit obtíže z pohledu poskytovatelů dávek sociálního zabezpečení, kterým bude nějakou dobu trvat, než se „vypořádaji“ s kolísáním příjmů (a vyhodnocením splnění podmínek nároku) na straně potenciálního subjektu dávek - zaměstnance s takto nepravidelným př́ijmem; dodejme - avšak stále ,pod smlouvou“ k zaměstnavateli, i když jen nepravidelně naplňovanou, pouze občasně poptávanou a následně vykonávanou prací.

Pokud bychom porovnali popisovanou britskou praxi se stávající českou pracovněprávní úpravou, musíme konstatovat, že i náš právní řád zná pracovněprávní instituty, které ve svém důsledku nemusí (předem) garantovat, že zaměstnanec odpracuje v určitém období určitý objem (hodin práce) a mohou vést v některém kalendářním měsíci i k efektu ,zero hours"16. Mnohé dohody o pracích konaných mimopracovní poměr (zejména dohody o provedení práce ve školství apod.) jsou v podstatě koncipovány jako právní rámec „práce na vyžádáni““ (např. na vysokých školách nemusí být dopředu zřejmé, kolika přednáškami, posudky, či počtem zkoušení bude dohoda o provedení práce „naplněna“, a tedy jaká „časová dotace“ bude na plnění dohody měsíčně věnována); konečně český zákonodárce $\mathrm{v} \S 74$ odst. 2 zákoníku práce šel této možnosti „naproti“ tím, že stanovil: „(2) V dohodách o pracích konaných mimo pracovni poměr není zamèstnavatel povinen rozvrhnout zaměstnanci pracovni dobu."

Český právní rád sice formulací § 74 dost. 1 ZPr: „(1) Zaměstnavatel má zajištovat plnění svých úkolů předevšim zaměstnanci v pracovním poměru." formálně preferuje pracovní poměr jako „typický“ pracovněprávní vztah, současně ale (podtrhuji, že v současné době, nebylo tomu tak vždy, srov. dobová znění obdobného ustanovení) v zákoníku práce použitá formulace (viz výše) z tohoto ustanovení dělá proklamativní text, $v$ podstatě nenormativního charakteru.

Česká varianta „zero hours“ však v praxi zásadní problémy nečiní (zejména zákonným omezením rozsahu práce, která na jejich základě může být konána), konečně i česká pracovněprávní teorie označuje tyto vztahy za „doplňkové pracovněprávní vztahy“, když je zřejmé, že těžiště pracovněprávních jistot (a v neposlední řadě odpovídajícího výdělku) a souvisejících práv v oblasti sociálně-právní, by měli ti, kteří „mohou a chtějí pracovat“, nacházet v navazování ne-doplňkových pracovněprávních vztahů. Pokud uzavřeme toto stručné srovnání, pak drtivá většina „českých dohodářu“ “ vnímá tyto doplňkové pracovněprávní vztahy opravdu doplňkově, nebot’ mají vedle nich zpravidla

\footnotetext{
4 DAVIS, A. C. L., Employment Law, Pearson Education Limited, ISBN 978-1-4082-6360, 2015.

5 DAVIS, A. C. L., Employment Law, Pearson Education Limited, ISBN 978-1-4082-6360, 2015, s. 121.

${ }^{16}$ Lze se setkat ojediněle i s př́ípady, kdy uzavřená dohoda o provedení práce není v období, na které je uzavřena, z různých důvodů vůbec „konzumována“. Autor je toho názoru, že pokud v dohodě o provedení práce není předem sjednán objem práce (pracovní doby), jejíž odpracování by zaměstnavatel zaměstnanci předem garantoval, nemůže být konečný „,nulový“ součet odpracovaných hodin v rozporu s právem; stranou této stručné úvahy byly záměrně ponechány možné varianty specifických okolností každého případu, které mohou mít vliv na různá „,vstupní“ očekávání stran a na posouzení jejich důvodnosti, včetně možných následků.
} 
navázán (více či méně) „plnohodnotný“ pracovní poměr, případně patří do skupiny „pracujících důchodců“, studentů či jiných „státních pojištěnců“.

Ve Velké Británii je však situace při užívání ,zero hours contracts“ zjevně odlišná, i proto se ve Spojeném království vedla (a částečně dosud vede) stran těchto smluv poměrně vyhraněná diskuse.

Bylo by nad rámec zamýšleného rozsahu tohoto př́íspěvku věnovat se na tomto místě poněkud obsáhlejší materii, kterou by čtenáři bylo nutné přiblížit pro objasnění, na základě jakých kritérií a s jakými důsledky rozlišuje britské právo mezi zaměstnanci a pracovníky, resp. přesněji, za užití anglické terminologie, mezi „employee“ a ,worker"; tomuto (v některých aspektech nepochybně inspirujícímu) rozlišování se budeme blíže věnovat v některých dalších publikačních výstupech našeho výzkumu. Na tomto místě proto pouze zjednodušeně uvedeme, že postavení „employee“ ve Spojeném království je v zásadě obdobou zaměstnance pracujícího v pracovním poměru ve smyslu českého pracovního práva, zatímco ,worker“ přiléhavou obdobu v českém pracovním právu nemá - pracuje sice osobně za odměnu na základě smlouvy nebo jiné dohody, z pohledu srovnání s českým pracovním právem se však nachází „na přechodu“ mezi ,zaměstnancem“a „osobou samostatně výdělečně činnou“ (,self-employed person“). Materiál, který britská vláda zpracovala v roce 2013 v rámci konzultací vedených k tématu „Zero hours employment contracts “ $\mathrm{k}$ tomu uvádí: „... kategorie pracovník (, worker ') je často vnímána jako hybrid zaměstnance (,employee") a statusu osoby samostatně výdělečně činné (, self-employed person'). ,Pracovnici ' mají méně ochrany než ,zaměstnanci ‘ $v$ domácím pracovním právu. Všichni, zaměstnanci ‘jsou, pracovníci‘. Ne všichni ,pracovníci 'však budou ,zaměstnanci ‘."17

Opět bychom mohli konstatovat, že z českého pohledu - nazíráno prizmatem dohod o pracích konaných mimo pracovní poměr - v zásadě „nic překvapivého“. Zaměstnanci v ČR jsou zvyklí na fakt, že jejich nároky jsou v těchto oblastech také zásadně zúžené oproti zaměstnancům pracujícím v pracovním poměru; rozdíl zde však je - je třeba opět zdůraznit, že tyto „méně chráněné““ pracovněprávní vztahy jsou v ČR jen ,doplňkové“.

Pro účely dalšího výkladu je však možné zjednodušeně uvést, že pro oba typy těchto zaměstnaneckých vztahů (employee/worker) platí, že pokud jednotlivec vykonává práci na příslušném smluvním základě, je možné dovozovat, že je zaměstnancem/pracovníkem (i když nikoliv s úplným vyloučením opačného závěru v konkrétním případě může mít ojediněle i postavení ,self-employed person“"), který má v případě výkonu práce nárok na zaměstnanecká/pracovní práva jako je minimální mzda ${ }^{18}$ („National Minimum Wage“19).

Davis v této souvislosti upozorňuje, že je však nepravděpodobné, že by někdo se ,zero hours contract“ mohl získat na delší dobu status ,employee“, tedy zaměstnance (např. za účelem možnosti obrany proti neoprávněnému propuštění nebo za účelem

17 „All 'employees' are 'workers'. However not all 'workers' will be 'employees'. “ Department for Business, Innovation and Skills. Consultation: zero hours employment contracts, 2013, dostupné online na: $<$ https://assets.publishing.service.gov.uk/government/uploads/system/uploads/attachment_data /file/267634/bis-13-1275-zero-hours-employment-contracts-FINAL.pdf >.

18 Srov. DAVIS, A. C. L. Employment Law, Pearson Education Limited, ISBN 978-1-4082-6360, 2015, s. 121.

19 Okolo 5 \% pracovníků ve Spojeném království dostává za práci minimální mzdu, srov. tamtéž, s. 240. 
vzniku nároku na odstupné při skončení pracovního poměru) a uzavírá, že je tomu tak pro neexistenci vzájemných povinností, s ohledem na absenci príslibu (povinnosti) poskytovat práci ze strany zaměstnavatele; pokud jsou v realizaci zaměstnání (ve výkonu práce) významné přeryvy, nemusí být též naplněna kontinuita zaměstnání, se kterou zákon tyto nároky spojuje ${ }^{20}$. Současně však Davis upozorňuje (tamtéž) na rozhodnutí Pulse Healthcare Ltd $v$ Carewatch Care Services Ltd \& Others [UKEAT/0123/12/BA]; na totéž rozhodnutí odkazuje i shora zmíněný konzultační materiál britské vlády, který uvádí: „Existuji mylné názory, že osoba pracujici pod, zero hours contract “ nemůže být nikdy zaměstnancem. To je nesprávné. Existuje judikatura Employment Appeal Tribunal (EAT), která přiznala status zaměstnanců (the employment status) zdravotním sestrám poskytujicim služby intenzivni péče, které pracovaly ve směnách rozvržených na základě ,zero hours contract'. EAT konstatoval, že písemné smlouvy neodrážejí skutečné postaveni stran. Zdravotni sestry nepracovaly ad hoc, ale pracovaly na svých pracovnich mistech, v pevně určeném čase pravidelně po několik let. EAT konstatoval, že zdravotní sestry byly zaměstnány na základě globálnich pracovnich smluv a nebyly žádné potiže s prokázáním kontinuity jejich zaměstnání. “21

Je zřejmé, že Odvolací pracovní tribunál (EAT) v této otázce věc posuzoval dle způsobu realizace obsahu smluvního ujednání, ne dle deklarované formy, resp. označení vztahu jeho stranami; ostatně dle obdobných principů by při posuzování obdobné věci postupovaly i soudy české. Již citovaná monografie kolektivu autorů (HIREL), $\mathrm{k}$ tomu uvádí: „Jestliže z podobného uspořádání vztahů vzniknou spory, soud či tribunál budou aplikovat prirozené principy (viz např. použití konceptu falešnélzastřenéltransakce $v$ prípadu Pulse Healthcare).“22

Prozatím jsme mohli konstatovat, že přes mnohá specifika britské právní úpravy lze najít v některých bodech i paralely ,zero hours contracts“ $\mathrm{s}$ dohodami o pracích konaných mimo pracovní poměr. Co však českého čtenáře zřejmě zarazí - a hledal by tuzemskou paralelu marně - je (či spíše byl) výskyt doložek exkluzivity v těchto smlouvách.

Ve Velké Británii v nedávné minulosti docházelo $\mathrm{k}$ tomu, že zaměstnavatelé požadovali po zaměstnancích uzavírání ,zero hours contracts“, které obsahovaly též ujednání o výhradnosti (,exclusivity clause“), stanovící, že zaměstnanec musí poskytovat svoje služby (práci) výlučně tomuto zaměstnavateli.

I bez této doložky je možnost zaměstnanců pracujících na základě ,zero hours contracts" přijmout jinou (další) práci poměrně limitována. Je tomu tak zejména proto, že se tito zaměstnanci obávají, že může dojít k situaci, že by po nich byla práce požadována ve stejné době z obou smluvních vztahů (od obou zaměstnavatelů). Zaměstnanec se tak obává, že pokud zaměstnavatel zavolá a zaměstnanec nebude připraven nastoupit k výkonu požadované práce, nemusí již být k práci příště vyzván nebo bude zhoršeno /sníženo/ jeho pořadí v rámci všech zaměstnanců čekajících na prríští zavolání; Davis k tomu uvádí, že u těchto druhů práce taková „pořadí“ existují a v rámci těchto pořadí je práce ve chvíli, kdy se „objevi““, častěji (přednostně) nabízena těm, kteří pracují (re-

\footnotetext{
20 Tamtéž, s. 121.

21 Consultation: zero hours employment contracts, s. 25.

22 HIREL, Issue 259, 57.01.
} 
flektují zavolání) pravidelně23. V tomto ohledu stojí za pozornost, že u mnohých z těchto zaměstnavatelů existují podobné systémy „hodnocení“ připravenosti zaměstnanců „naskočit do procesu“, jaké známe z případů „spolupracovníků“ pracujících pro různé platformy v rámci „ekonomiky sdílení“; je zřejmé, že obavy z celosvětově postupující „uberizace“ práce, jednoznačně spojené s mizením klasických pracovních míst a jejich „nahrazování“ pseudo-dodavatelskými vztahy s minimální ochranou, nejsou v tomto ohledu liché24.

Právě existenci a nadužívání doložek exkluzivity identifikovala britská vláda při zahájení shora uvedených konzultací v roce 2013 jako jedno z rizik, v prrípadě, kdy tyto doložky: „... brání tomu, aby jedna osoba pracovala pro jiného zaméstnavatele, $i$ když současný zaměstnavatel nenabizi žádnou práci“ ${ }^{25} \mathrm{Na}$ druhé straně sám fakt, že na základě ,zero hours contracts“ v té době pracovalo ve Spojeném království již okolo 250000 pracovníků, dával tušit, že úplní odpůrci ,zero hours contracts“ se naplnění svých očekávání zřejmě nedočkají. Tomu, že britská vláda v podstatě již dopředu přistoupila ke konzultacím s tím, že institut stále více oblíbený mnohými zaměstnavateli ve své podstatě ,podrží“, ostatně napovídala již formulace předmluvy, kterou pro konzultační materiál připravil státní tajemník pro podnikání, inovace a dovednosti a předseda obchodní rady, člen sněmovny Vince Cable, ze které je možné pro ilustraci ocitovat: „Vláda se zavázala k dosažení flexibilního a spravedlivého trhu práce. Politikou vlády je vytvořit u zaměstnavatelì di̊věru k prijímání nových zaměstnanců a $k$ vytvárení nových pracovnich mist a poskytnout rámec, který jednotlivcům umožní nejen najít práci, ale najít práci, která vyhovuje jejich individuálním potřebám. ... ,Zero hours contracts “ jsou v některých odvětvích používány zodpovédně po mnoho let. Mohou podporovat flexibilitu podnikání, usnadnit nábor nových zaměstnanců a poskytnout mladým lidem cestu $k$ zaměstnání. Tyto smlouvy a dalši pružná opatření dávají jednotlivcưm možnost většiho výběru a možnost sladění práce s ostatními závazky ... “26

Davis k tomu uvedl, že vládní konzultace byla komentátory „odsouzena“ proto, že v principu přijala zero hours working jako legitimní formu uspořádání, které přináší flexibilitu pracovnímu trhu ve prospěch pracujících stejně jako zaměstnavatelů. ${ }^{27}$

V podstatě jediným př́mým důsledkem vládních konzultací na podobu britského právního řádu byl zákaz sjednávání doložek exkluzivity v ,zero hours contracts“, který byl realizován vložením nových ustanovení (Section 27A a 27B) do The Employment Rights Act 1996 (ERA), prostřednictvím Small Business, Enterprise and Employment Act 2015. S účinností od 11. ledna 2016 označuje zákon jakékoli ustanovení ,zero hours contract“, které zakazuje pracovníkovi vykonávat práci nebo vykonávat služby na základě jiné smlouvy nebo jiné dohody, nebo podmiňuje výkon takové práce přechozím souhlasem zaměstnavatele, za nevymahatelné vůči pracovníkovi.

23 Srov. DAVIS, A. C. L., Employment Law, Pearson Education Limited, ISBN 978-1-4082-6360, 2015, S. 121.

$24 \mathrm{~K}$ tomuto jevu srov. např. PICHRT, J. - BOHÁČ, R. - ELISCHER, D. - KOPECKÝ, M. - MORÁVEK, J. (eds.). Sdílená ekonomika a delikty. Praha: Wolters Kluwer ČR, 2018.

25 Consultation: zero hours employment contracts, s. 5.

26 Tamtéž, s. 4.

27 Srov. DAVIS, A. C. L., Employment Law, Pearson Education Limited, ISBN 978-1-4082-6360, 2015, S. 122. 
Paradoxně tak v důsledku shora uvedených konzultací došlo sice k zákazu skandálních doložek exkluzivity (na jejichž základě zaměstnavatel, který pro zaměstnance práci neměl a ani mu ji nemusel nabídnout, přesto vyžadoval, aby tento zaměstnanec nepracoval ani pro nikoho jiného - tedy mj. omezoval zaměstnance bezekvivalentně a se všemi škodlivými dopady na trh práce, včetně dopadu do oblasti sociálních dávek, jejichž uživateli se takto $\mathrm{z}$ trhu práce vyřazení $\mathrm{v}$ důsledku často stávali), avšak současně došlo k tomu, že se dosud pouze „kategorie ekonomická“ (viz HIREL výše) stala „kategorií právní“, nebot' v ustanovení 27A ERA nově obsahuje i definici těchto smluv. I když se zdánlivě jedná o vymezení těchto smluv pouze pro účely zákazu doložek exkluzivity, je zřejmé, že britská právní definice ,zero hours contracts“ spatřila „světlo světa“. Britská vláda, tím nepochybně zcela vzala naděje zastáncům úplné eliminace tohoto institutu a naopak potěšila všechny zaměstnavatele používající tento nástroj, tak nehezky evokující scény z historických filmů o najímání dělníků v době krize na jeden den jejich výběrem $\mathrm{z}$ davu na bráně továrny.

V říjnu 2015 pak došlo k vydání vládních pokynů pro zaměstnavatele týkajících se ,zero hours contracts“ (Zero hours contracts: guidance for employer). ${ }^{28}$ Je např. doporučováno neuživat ,zero hours contracts“ pro účely zajištění hlavního předmětu činnosti (hlavní služby), a pokud jsou použivány, doporučuje se věnovat co nejvíce pozornosti procesu nabízení $i$ ukončování výkonu práce na jejich základě. Lze souhlasit $\mathrm{s}$ Lewisovou ${ }^{29} \mathrm{v}$ tom, že tyto pokyny sice stanovily postupy pro správnou praxi, nejsou však právně vynutitelné a nevyřeší tedy skutečné potíže, kterým čelí zaměstnávání na základě takových smluv.

Závěrem je možné konstatovat, shodně s většinou teoretiků pracovního práva, že (vedle) mnohých pozitiv) je rozšiřování atypických pracovněprávních vztahů též jedním z důvodů zhoršeného dodržování a „vymahatelnosti“ pracovněprávních předpisů. Davidov k tomu uvádí, ${ }^{30}$

že práce na částečný úvazek, $\mathrm{z}$ domova, $\mathrm{v}$ nepravidelném rozvržení, práce na základě ,zero hours contracts“ nebo v jiném ,atypickém“ uspořádání, má dva významné důsledky z hlediska dodržování práva a jeho vymahatelnosti. Prvním důsledkem je, že tyto druhy ,zapojení“ zaměstnanců vedou ve svém důsledku k menší četnosti kontaktů mezi pracovníky pracujícími pro stejného zaměstnavatele, což v důsledku vede $\mathrm{k}$ tomu, že tito pracovníci jsou méně obeznámeni se svými právy, resp. si je méně uvědomují a oslabeno je i jejich vlastní úsilí o jejich prosazování. Druhým následkem je omezení schopnosti orgánů inspekce práce účinně působit $\mathrm{k}$ prosazení zákona $\mathrm{v}$ rámci takto „rozptýlených“" pracovních sil.

Je zjevné, že výhody i nevýhody veškerých atypických aranžmá v pracovněprávních vztazích by měly být zákonodárcem vždy uvážlivě zvažovány; skutečně fungující so-

28 Dostupné online na: <https://www.gov.uk/government/publications/zero-hours-contracts-guidance-for -employers/zero-hours-contracts-guidance-for-employers $>$.

29 Srov. LEWIS, T. Employment law: an adviser's handbook. 12th edition. Legal Action Group. ISBN 9781908407948, 2017, s. 21.

30 DAVIDOV, G. A Purposive Approach to Labour Law. Oxford University Press 2016. Published 2016 by Oxford University Press, s. 228. 
ciální dialog nad nově vytvářenou pracovněprávní legislativou by pak měl být garancí před přijímáním podobně nevyvážených modelů.

prof. JUDr. Jan Pichrt, Ph.D.

Právnická fakulta Univerzity Karlovy

pichrt@prf.cuni.cz 



\title{
MEDZI ZAMESTNANCOM A SAMOSTATNE ZÁROBKOVO ČINNOU OSOBOU
}

\author{
ANDREJ PORUBAN*
}

\begin{abstract}
Between an employee and an independent contractor
This paper aims at discussing the new approach to regulating the so-called platform work by looking at the main initiatives. It briefly describes the pros and cons of potential thirdcategory between employees and independent contractors and potential.
\end{abstract}

Keywords: employment relationship; employee; independent contractor; third category

Klíčová slova: pracovnoprávny vztah; zamestnanec; samostatne zárobkovo činná osoba; tretia kategória

DOI: $10.14712 / 23366478.2019 .8$

\section{ÚVOD}

Moderné technológie intenzívne transformujú pracovné právo už viac ako dve dekády. Spočiatku ich vpád súvisel s prehlbovaním dispozičnej právomoci zamestnávatel'a. To sa týka predovšetkým zásahov do súkromia zamestnancov (napr. monitorovanie pracoviska, zaznamenávanie telefonických hovorov, kontrola elektronickej pošty), či zintenzívňovaním pracovnej zát'aže (zamestnanec na telefóne 24 hodín denne, práca doma mimo rozvrhu pracovných zmien, atd’.). Dnes dochádza k ovplyvňovaniu spôsobov organizácie práce aj inak. S dostupnost’ou internetu a inteligentných telefónov dochádza k väššiemu dopytu po flexibilnejších typoch zamestnávania. Pre informačno-komunikačným nástrojom sa interný zamestnanec $\mathrm{v}$ klasickom pracovnoprávnom vzt’ahu stáva čím d’alej menej žiadaný. Jeho činnost' je nahradzovaná ad hoc poskytovatel'mi služieb, ktorí sa pohybujú v online sfére. Riadenie pracovného procesu sa uskutočňuje automatizovaným spracovaním vel'kého množstva dát a prostredníctvom algoritmov.

\footnotetext{
* Autor je odborným asistentom na katedre pracovného práva a práva sociálneho zabezpečenia Právnickej fakulty Univerzity Komenského v Bratislave. Príspevok vznikol v rámci riešenia projektu Vedeckej grantovej agentúry Ministerstva školstva, vedy, výskumu a športu Slovenskej republiky a Slovenskej akadémie vied (VEGA) reg. číslo 1/0908/17 pod názvom Zamestnávanie mladých l'udí v čase hospodárskych zmien vo svetle migračnej krízy - nové výzvy pre politiku trhu práce (právny a - ekonomický pohlad).
} 


\section{VYTVORENIE TRETEJ KATEGÓRIE}

Pod tlak sa tak dostáva aj zaužívaná taxonómia, ktorá sa odvíja od definície závislej práce. Dvojkol'ajnost' zamestnanec vs. samostatne zárobkovo činná osoba sa uplatňuje i v našich právnych poriadkoch. ${ }^{1} \mathrm{~S}$ rastom neštandardných foriem práce je spojená tiež otázka, kto už spadá do prvej skupiny a kto ešte nie, čo vedie k návrhom právnych a politických reforiem. ${ }^{2}$ Do úvahy pripadá niekol'ko základných alternatív ${ }^{3}$ :

i/ prehodnotenie všetkých právnych predpisov a ich prispôsobenie na podmienky platformovej práce,

ii/ vyňatie zo súčasného právneho rámca a vytvorenie špeciálnej úpravy,

iii/ vytvorenia hybridnej kategórie na pomedzí zamestnancov a samostatne zárobkovo činnými osobami ${ }^{4}$.

\section{VÝHODY TRETEJ KATEGÓRIE}

Posledná možnost ${ }^{5}$ vychádza z tradičných rozdielov medzi zamestnancami a nezávislými dodávatel'mi, ktoré však strácajú relevanciu pre čoraz väčšiu čast' pracovnej sily. Súčasné rozlišovanie vytvára nejasnosti a administratívnu zát’až a nie je zrejmé, ako sa takéto delenie zhoduje s ciel'mi pracovného práva. ${ }^{6}$ Väčšina kl'účových práv, ktoré sú spriaznené s ochranou slabšej zmluvnej strany, je k dispozící́ iba zamestnancom (hlavne zákaz svojvol'ného prepúšt’ania, nárok na minimálnu mzdu, najvyššia prípustná dížka pracovného času, primeraný odpočinok po práci, najkratšia prípustná dížku platenej dovolenky na zotavenie, právo slobodne sa združovat' v odboroch a na kolektívne vyjednávanie + špecifické právo na sociálne zabezpečenie). Ich rozšírenie aj

1 § 1 ods. 2 Zákonníka práce č. 311/2001 Z. z.: „Závislá práca je práca vykonávaná vo vzt'ahu nadriadenosti zamestnávatel'a a podriadenosti zamestnanca, osobne zamestnancom pre zamestnávatel'a, podl'a pokynov zamestnávatel'a, v jeho mene, v pracovnom čase určenom zamestnávatel'om."

$\S 2$ Zákoníku práce č. 262/2006 Sb.:

„(1) Závislou praci je práce, která je vykonávána ve vztahu nadřizenosti zaměstnavatele a podřizenosti zaměstnance, jménem zaměstnavatele, podle pokynů zaměstnavatele a zaměstnanec ji pro zaměstnavatele vykonává osobně.

(2) Závislá práce musí být vykonávána za mzdu, plat nebo odměnu za práci, na náklady a odpovědnost zaměstnavatele, v pracovní době na pracovišti zaměstnavatele, popripadě na jiném dohodnutém mistě."

2 JOHNSTON, H. - LAND-KAZLAUSKAS, C. Organizing on-demand: Representation, voice, and collective bargaining in the gig economy. Conditions of work and employment series. Geneva: ILO, 2018, no. 94, p. 32.

3 Napr. KENNEDY, J. V. Three Paths to Update Labor Law for the Gig Economy, s. 2. Dostupné online na: $<$ http://www2.itif.org/2016-labor-law-gig-economy.pdf $>$.

4 V slovenskej literatúre o modeli hybridného zamestnanca hovorí BARANCOVÁ, H. Zamestnanec, štatutár a spoločník v pracovnom práve. Praha: Leges, 2018, s. 20.

5 Nejde o úplne prevratnú myšlienku. S kvázi zamestnancami sa môžeme s určitými osobitost'ami stretnút' už teraz v Taliansku (lavoratori parasubordinati), v Nemecku (arbeitnehmerähnliche Personen), Izraeli, Španielsku, Portugalsku, Vel'kej Británii či Kanade. Viac Non-standard employment around the world: Understanding challenges, shaping prospects. Geneva: ILO. 2016, s. 37-39.

6 ADAMS, A. - FREEDMAN, J. - PRASSL, J. Rethinking Legal Taxonomies For The Gig Economy. Oxford Review of Economic Policy, 2018, vol. 34, č. 2. 
na ostatných pracujúcich bez ohl'adu na právne postavenie by pritom nemuselo neprimerane ekonomicky poškodzovat' potenciál platformovej práce. ${ }^{7} \mathrm{~V}$ neposlednom rade sa tu otvára priestor na využívanie predností z oboch pôvodných kategóriii ${ }^{8}$, napr. pracovnoprávna ochrana spolu s výhodami v daňovej a odvodovej oblasti.

\section{NEVÝHODY TRETEJ KATEGÓRIE}

Kreovanie tretej kategórie nie je všeliek na problémy, ktorým čelí pracovné právo v 21. storočí. Bez poznania konkrétneho obsahu práv, ktoré by k nej patrili, je t’ažké posúdit' jej pozitíva. ${ }^{9}$ Napriek tomu sa domnievam, že zavedenie autonómnej kategórie by nebolo užitočné. Nepovedie k efektívnejšiemu fungovania celého systému, ale spôsobí skôr jeho neprehl'adnost'. Hlavný problém rigidného binárneho rozlišovania síce zmizne. Čiary oddel'ujúce jednotlivé kategórie sa však nezrušia, ale zdvojnásobia. Hranice budú stále rovnako neisté a nebudú vždy vyhovovat' situáciám, ktoré môže trh práce priniest'. Vylúčit' nemožno ani vznik nových otázok a možné nezamýšl'ané vedl'ajšie účinky. ${ }^{10}$ Okrem toho intermediárna kategória by nemala byt’ chápaná ako riešenie nesprávnej klasifikácie tzv. falošných/nútených živností. ${ }^{11}$

\section{ZÁVER}

Na jednej strane je nutné uznat', že charakterizujúce kritéria statusu zamestnanca podl'a definície závislej práce nie sú optimálne. Na strane druhej sú stále dostatočne pružné, aby sa mohli aplikovat’ aj na neštandardné formy zamestnávania. Posúdenie bude individuálne a bude vždy závisiet’ od okolností toho-ktorého prípadu. Z hl'adiska závislej práce ako podstaty pracovného práva ide iba o pokračovanie neustálych konfliktov, čo ešte je pracovnoprávny vzt’ah a čo už podnikanie. Digitálna éra si jednoznačne vyžaduje prispôsobenie sa realite. Lenže primárnou požiadavkou bez potreby koncepčných zásahov do pracovného práva - by mali byt’ nové prístupy $\mathrm{k}$ interpretovaniu prvkov nesamostatnej práce. Tie sa dotýkajú najmä znakov ako subordinácia, podl'a pokynov, v mene zamestnávatel'a a v pracovnom čase určenom zamest-

7 FLORISSON, R. - MANDL, I. Platform work: Types and implications for work and employment - Literature review. Luxembourg: Publications Office of the European Union, s. 96.

8 Z perspektívy osobnej a vecnej pôsobnosti práva Európskej únie sa ako nevyhnutná javí aj d’alšia existencia večnej dichotómie medzi pracovníkom a samostatne zárobkovo činnou osobou podl'a právnych predpisov Európskej únie. Európski zákonodarcovia ani Súdny dvor Európskej únie vo svojej judikatúre zatial' nezaviedli akúkol'vek prechodnú kategóriu. In BEDNAROWICZ, B. Decent Work in the Gig Economy under European Union Law: Utopia or Dystopia? Príspevok prednesený na ILERA World Congress 2018.

9 ALOISI, A. - CHERRY, M. A. A Third Employment Category for On-Demand Workers? Oxford Business Law Blog, 2016. Dostupné online na: <https://www.law.ox.ac.uk/business-law-blog/blog/2016/11/third -employment-category-demand-workers $>$.

10 DE STEFANO, V. - HENDRICKX, F. Gig economy, platform work, and the binary worker categorisation. In: SOMERS. M. (ed.). Vorm geven aan digitale tijden. Sint-Gillis: Denktank Minerva, 2018, s. 108.

11 DAVIDOV, G. - FREEDLAND, M. - KOUNTOURIS, N. The Subjects of Labour Law: 'Employees' and other Workers. In: FINKIN, M. - MUNDLAK, G. (eds.). Comparative Labor Law. Cheltenham: Edward Elgar. 2015, s. 115-131. 
návatel'om, ktoré sa môžu javit' ako sporné. To však nie je žiadna novinka, ale vd’aka platformovej práci sa opät' vraciame $\mathrm{k}$ fundamentálnym otázkam pracovného práva ako relatívne samostatného právneho odvetvia.

JUDr. Andrej Poruban, PhD.

Katedra pracovného práva a práva sociálneho zabezpečenia

Právnická fakulta Univerzity Komenského v Bratislave

andrej.poruban@flaw.uniba.sk 


\title{
NÁHRADA NEMAJETKOVÉ ÚJMY A DALŠÍ PRÁVNÍ VZTAHY ÚČASTI NA PRÁCI
}

\author{
LUCIE MATĚJKA ŘEHOŘOVÁ*
}

\begin{abstract}
Non-pecuniary damages and other employment relationships
The paper analyses different approaches to the issue of non-pecuniary damage compensation in selected other employment relationships, focusing on service relationships. The object of the paper is in particular to point out the substantive and procedural implications of the concept of the non-pecuniary damages and its consequences for the enforcement of the rights of the individual victim.
\end{abstract}

Keywords: non-pecuniary damage; employee; compensation for injury; service relationships

Klíčová slova: nemajetková újma; zaměstnanec; náhrada újmy; služební vztahy

DOI: $10.14712 / 23366478.2019 .9$

\section{ÚVODEM}

Referent na ministerstvu, hasič, policista, voják z povolání, justiční čekatel, advokátní koncipient, úředník územně samosprávného celku, pedagog, zdravotní sestra. To je jen skromný výčet z množiny povolání, jejichž společným jmenovatelem je regulace výkonu závislé činnosti nikoli pouze zákoníkem práce (př́ípadně subsidiárně aplikovatelnými ustanoveními občanského zákoníku) a souvisejícími právními předpisy, ale i jinými právními předpisy, které stojí vedle zákoníku práce (či spíše před zákoníkem práce) a je vůči jeho úpravě v postavení leges specialis. Zmíněné speciální právní předpisy formují více či méně podrobný rámec práv a povinností doplňující základní pracovněprávní úpravu o další soubor závazků reflektujících specifika dané činnosti.

Zákoník práce je základním a obecným právním předpisem pracovního práva, který upravuje právní vztahy vznikající při výkonu závislé práce. Smyslem a účelem pracovněprávních předpisů je prostřednictvím organizačních a ochranných nástrojů regulovat výkon závislé práce zaměstnance pro zaměstnavatele. Jedním z definujících činitelů základních pracovněprávních vztahů je dlouhodobý a kontinuální výkon závislé práce zaměstnance (v organizační podřízenosti) pro zaměstnavatele (v organizační nadříze-

\footnotetext{
* Mgr. Lucie Matějka Řehořová působí na Katedře pracovního práva a práva sociálního zabezpečení Právnické fakulty Univerzity Karlovy jako interní doktorandka a zároveň jako advokátka v Praze.
} 
nosti). Jedná se o osobní vztah založený na vzájemné důvěře obou subjektů, kterým si drtivá většina ekonomicky aktivních lidí obstarává prostředky pro svoji obživu. I přestože je tento typ soukromoprávního vztahu realizovaný ve společnosti masově, ne vždy je zákoník práce a s ním související právní předpisy jediným základním stavebním kamenem pro výkon konkrétní závislé činnosti.

Vedle základní úpravy pracovněprávních vztahů obsažené v zákoníku práce, existují činnosti, které vyžadují specifickou úpravu pro svoji realizaci. Zákoník práce jejich existenci nepř́mo připouští a naznačuje prostřednictvím ustanovení $§ 5$. Doktrínou jsou tyto specifické pracovněprávní vztahy označovány jako „další právní vztahy účasti na práci“" Za účelem identifikace príléhavého souboru konkrétních práv a povinností, které vůči sobě zaměstnanec a zaměstnavatel $\mathrm{v}$ těchto dalších právních vztazích účasti na práci vykonávají, je nezbytné nejprve správně stanovit interpretační pravidla pro podřízení daného právního vztahu těmto normám a určit právní předpis, který se bude na př́slušnou závislou činnost aplikovat. $V$ prípadě úpravy daného právního vztahu speciálním právním předpisem, je zapotřebí dále odpovědně určit jeho vztah a poměr vi̊či zákoníku práce. ${ }^{1}$

Ustanovení § $5 \mathrm{ZP} \mathrm{v}$ tomto kontextu představuje pomyslnou dvoukř́́dlou malovanou skřín z pohádky s tajným vchodem, za kterým se skrývá spletitá a pestrá množina právních vztahů účasti na práci, která má navíc široký potenciál k dalšímu vývoji.

Otázka náhrady nemajetkové újmy v dalších právních vztazích účasti na práci zůstává doposud na okraji zájmu odborné právnické obce, a to i přsestože se týká nemalého počtu zaměstnanců. Jak bude nastíněno v následujících odstavcích, tento určitý zájmový deficit o předmětné téma se zdá být s ohledem na množství otázek, které předmětná právní regulace uvedené oblasti vyvolává, nedůvodný. Předmětem a cílem předkládaného příspěvku je označit a analyzovat jednotlivé systémy náhrady nemajetkové újmy v rámci služebních poměrů a dalších vybraných právních vztahů účasti na práci, které obsahují speciální zákonnou úpravu náhrady nemajetkové újmy. Snahou je zejména poukázat na hmotněprávní a procesní dopady zákonodárcem zvolené koncepce úpravy náhrady nemajetkové újmy a jejich konsekvence při vymáhání práv jednotlivých poškozených.

\section{DALŠÍ PRÁVNÍ VZTAHY ÚČASTI NA PRÁCI - PRAMENY PRÁVNÍ ÚPRAVY}

I přestože se z podoby současné textace dvou odstavců ustanovení § $5 \mathrm{ZP}$ jeví jeho působnost omezená pouze na vztahy vyplývající z výkonu veřejné funkce, historicky bylo toto ustanovení obsáhlejší a jeho široký dosah zůstává prostřednictvím doktrinálního výkladu zachován i nadále.

Za dobu účinnosti zákoníku práce nebylo ani ustanovení § 5 ZP ušetřeno novelizací, z nichž ty nejvýznamnější měly vůči jmenovanému ustanovení vždy derogační účinky, když byly z původních pěti odstavců zachovány do současného znění zákona

1 Nabízí se v zásadě čtyři možnosti vzájemného vztahu mezi zákoníkem práce a speciálním právním předpisem. 1. Vyloučení aplikace zákoníku práce. Speciální předpis bude samostatně aplikovanou normou. Tento př́istup není v souvislosti s dalšími právními vztahy účasti na práci zákonodárcem využíván, když úplné vyloučení zákoníku práce by ve svém důsledku znamenalo nutnost parafrázování většiny ustanovení 
pouze první dva. Novela zákoníku práce provedená zákonem č. 365/2011 Sb., jež byla zákonodárcem prezentována veřejnosti jako jedna z významných koncepčních novel zákoníku práce, zrušila s účinností $\mathrm{k} 1.1 .2012$ v $§ 5$ původní odstavce 4 a 5 , upravující další veřejné funkce (včetně poznámek pod čarou odkazující na příslušné speciální právní předpisy), na jejichž výkon byl aplikován zákoník práce ve vtahu subsidiarity či delegace. ${ }^{2}$ První derogační zásah byl podle důvodové zprávy ${ }^{3}$ uskutečněn s cílem upravit postavení zákoníku práce vůči zvláštním právním předpisům napříště nikoli v pozici jednotné úpravy veškerých pracovněprávních vztahů v České republice, která presumuje vztahy ke zvláštním zákonům, nýbrž jako zákona základního. Zákonodárce přitom vycházel z předpokladu, že ačkoli nebudou právní úpravy odchylné od zákoníku práce výslovně uvedeny v zákoně, nebude to znamenat, že by nadále nemohly být odchylné úpravy pracovněprávních vztahů v jiných zákonech stanoveny. ${ }^{4} \mathrm{~K}$ druhému derogačnímu zásahu do ustanovení $§ 5$ ZP došlo v souvislosti s harmonizací pracovního práva s rekodifikovaným soukromým právem prostřednictvím hlavního změnového předpisu, tedy zákona č. 303/2013 Sb., kterým se mění některé zákony v souvislosti s přijetím rekodifikace soukromého práva. Zákon č. 303/2013 Sb. zrušil s účinností k 1. 1. 2014 v § 5 ZP původní třetí odstavec, upravující subsidiární použití zákoníku práce na pracovní vztahy mezi družstvem a jeho členy. ${ }^{5} \mathrm{Z}$ důvodové zprávy k zákonu č. 303/2013 Sb. vyplývá zrušení třetího odstavce s odkazem na ust. § 579 zákona č. 90/2012 Sb., o obchodních společnostech a družstvech, dle kterého se počítá

zákoníku práce, ačkoliv objektem obou právních vztahů je závislá práce a obsahem pracovní závazek. 2. Př́ímá působnost. Na další právní vztahy účasti na práci se působnost zákoníku práce vztahuje, pokud to zákoník práce výslovně stanoví. 3. Delegace. Působnost zákoníku práce se na další právní vztahy účasti na práci vztahuje, pokud to zvláštní předpisy stanoví. 4. Subsidiarita. Působnost zákoníku práce se na další právní vztahy účasti na práci vztahuje, pokud zvláštní předpis nestanoví jinak.

2 Derogovaný čtvrtý a pátý odstavec ustanovení $§ 5$ ZP ve znění do 31. 12. 2011 (citace provedena bez odkazů na poznámky pod čarou):

„(4) Na pracovněprávní vztahy justičních čekateli̊, státních zástupců, právních čekateli̊ a na zaměstnance vykonávajici ve správních úradech státní správu jako službu, kterou Česká republika poskytuje veřejnosti podle služebního zákona, se tento zákon vztahuje, jen pokud to výslovně stanoví nebo pokud to stanoví zvláštni právni předpisy.

(5) Pracovněprávní vztahy čekateli̊ připravujicích se na výkon státní služby, úředníkủ územních samosprávných celků, akademických pracovníků vysokých škol, pedagogických pracovníkü, řediteli̊ veřejných výzkumných institucí, velitelư plavidel a členů posádek plavidel provozujících námoŕní plavbu, zaměstnanců v Probační a mediační službě, advokátů vykonávajících advokacii v pracovním poměru, asistentů soudců, asistentů státních zástupců, veřejného ochránce práv, zástupce verejného ochránce práv, finančního arbitra, zástupce finančního arbitra, notářských kandidátů, notárských koncipientů, exekutorských kandidátů, exekutorských koncipientů a advokátnich koncipientů se ř́dí tímto zákonem, pokud zvláštní právní předpis nestanoví jinak."

3 Důvodová zpráva k zákonu č. 365/2011 Sb. Parlament České republiky, Poslanecká sněmovna, 6. volební období, 2010-2013, tisk 411/0.

4 Zákoník práce původně převzal úpravu, podle které měl zabezpečovat jednotnou platformu pro pracovněprávní vztahy v České republice s tím, že jakékoli odchylky ve vztahu ke zvláštním zákonům měly být nejenom umožněny, ale zároveň zákonem presumovány. Podle důvodové zprávy se tento přístup nezdál být účelným, nebot' legislativní proces není schopen předpokládat a postihnout všechny možné odchylky a zákonný stav se tak vždy bude opožd'ovat za skutečností.

5 Derogovaný třetí odstavec ustanovení § 5 ZP ve znění do 31. 12. 2014 (citace provedena bez odkazů na poznámky pod čarou): ,(3) Pracovní vztahy mezi družstvem a jeho členy se ř́dí tímto zákonem, nestanoví-li zvláštní právní předpis jinak.“ 
s účinností od 1. 1.2014 jen s pracovním poměrem člena družstva, který bude pro družstvo vykonávat závislou práci. ${ }^{6}$

Mezi speciální právní předpisy upravující další právní vztahy účasti na práci se standardně řadí zákon č. 234/2014 Sb., o státní službě7, zákon č. 361/2003 Sb., o služebním poměru př́slušníků bezpečnostních sborů8 ${ }^{8}$, zákon č. 150/2017 Sb., o zahraniční službě , zákon č. 221/1999 Sb. o vojácích z povolání10, zákon č. 312/2002 Sb., o úřrednících územně samosprávných celků, zákon č. 111/1998 Sb., o vysokých školách, zákon č. 283/1933 Sb., o státním zastupitelství, zákon č. 85/1996 Sb., o advokacii a jiné.

Předmětem komparace a zkoumání v rámci předkládaného př́spěvku bude úprava a zvolený systém náhrady nemajetkové újmy v případě služebních poměrů.

\section{NÁHRADA NEMAJETKOVÉ ÚJMY STÁTNÍHO ZAMĚSTNANCE PODLE ZÁKONA O STÁTNÍ SLUŽBĚ}

První část příspěvku je věnována náhradě nemajetkové újmy státnímu zaměstnanci ve smyslu zákona o státní službě, když služební poměry státních zaměstnanců tvoří nejpočetnější skupinu dalších právních vztahủ účasti na práci co do počtu zúčastněných zaměstnanců.

Zvláštní právní úprava pro zaměstnance státu, resp. veřejné správy je odrazem tradičního př́istupu demokratických zemí $\mathrm{k}$ zaměstnancům činným ve služebním poměru regulovaným zvláštní právní úpravou, která by měla být ovládána zásadami odlišnými od smluvních principů v tržní sfére soukromoprávních pracovněprávních vztahů, a to především prostřednictvím uložení zvýšených povinností státním zaměstnancům za účelem stabilního a profesionálního výkonu veřejné správy. Hlavním smyslem přijetí zvláštní právní úpravy regulující služební poměry státních zaměstnancủ je odpolitizování státní služby tím, že je personálně oddělená od politické moci. ${ }^{11,12}$

Zákon o státní službě reguluje náhradu škody, služební úrazy a nemoci z povolání ve své šesté části, která obsahuje pouze několik delegačních ustanovení odkazujících na příslušnou úpravu zákoníku práce. Př́slušná hmotněprávní pravidla zákoníku práce se

${ }^{6}$ Důvodová zpráva k zákonu č. 303/2013 Sb. Parlament České republiky, Poslanecká sněmovna, 6. volební období, 2010-2013, tisk 930/0.

7 Dále jen „zákon o státní službě“ či „ZSS“.

8 Dále jen „zákon o služebním poměru př́slušníků bezpečnostních sborư“ či „ZSP“.

9 Dále jen „zákon o zahraniční službě“ či „ZZZ“.

10 Dále jen „zákon o vojácích z povoláni““ či „ZVP“.

11 Přestože měly ve svých programových prohlášeních všechny demokratické vlády po sametové revoluci obsažený závazek přijetí zákona o státní službě civilních zaměstnanců, ke konkrétní př́ípravě zákona došlo až v souvislosti s tlakem Evropské unie, která jako jednu z podmínek príijetí České republiky do Evropské unie stanovila príijetí zákona o státní službě. Návrh zákona o službě státních zaměstnancủ ve správních úřadech a o odměňování těchto zaměstnanců a ostatních zaměstnanců ve správních úřadech byl přijat pod č. 218/2002 Sb. jehož účinnost byla nakonec odkládána dvanáct let. Až po hrozbě sankcemi ze strany Evropské unie se zákonodárce $\mathrm{v}$ otázce státní služby přiklonil $\mathrm{k}$ vypracování návrhu nového zákona, který byl přijat pod č. 234/2014 Sb., a který v konečném důsledku politický vliv na státní zaměstnance spíše prohloubil. Uvedené přiléhavě odráží přetrvávající politickou nechut' na jakékoli oficiální, efektivní a funkční úpravě služebních poměrů státních zaměstnanců.

$12 \mathrm{~K}$ tomu srov. PICHRT, Jan a kol. Zákon o státní službě. Komentář. 1. vydání. Praha: Wolters Kluwer, 2015. 
tak v souladu s ust. § 124 zákona o státní službě uplatní i na náhradu nemajetkové újmy způsobené státnímu zaměstnanci.

Nedávný vývoj náhrady nemajetkové újmy v oblasti pracovního práva lze bez nadsázky považovat za mimořádně pestrý. Po účinnosti rekodifikovaného občanského zákoníku byl systém náhrady nemajetkové újmy vzniklé při plnění pracovních úkolů nebo v př́mé souvislosti s ním podroben důkladné revizi. K této revizi nicméně došlo až po bezmála dvou letech účinnosti nového občanského zákoníku, přičemž uvedené prodlení vyvolalo v praxi nemalé problémy. Vzhledem k účinnosti zákona o státní službě jsou veškeré komplikace v pracovněprávní aplikační praxi způsobilé ovlivnit i služební poměry státních zaměstnanců a s ohledem na délku jednotlivých promlčecích lhůt se stále jedná o ,živé“ téma.

Podle ustanovení § 394 odst. 2 zákoníku práce (ve znění do 30. 9. 2015) se do doby nabytí účinnosti právní úpravy úrazového pojištění při odškodňování bolesti a ztíŽení společenského uplatnění postupovalo podle vyhlášky Ministerstva zdravotnictví č. 440/2001 Sb., o odškodnění bolesti a ztížení společenského uplatnění (známá také pod označením „náhradová vyhláška). Její zrušení k 1. 1. 2014 však zamíchalo pracovněprávními kartami, nebot' nebylo jasné, zda podle pravidel již zrušeného právního předpisu nadále nahrazovat újmu způsobenou pracovním úrazem či nemocí z povolání. K nastalé situaci se nikoli nezajímavě vyjádřilo Ministerstvo práce a sociálních věcí, které ke dni 28. 1. 2014 zveřejnilo ve shodě s Ministerstvem zdravotnictví Společné stanovisko k postupu při odškodňování pracovních úrazů a nemocí z povolání po nabytí účinnosti nového občanského zákoníku a kde bylo ve stručnosti konstatováno, že se nadále postupuje podle (v té době již zrušené) náhradové vyhlášky.

Po nabytí účinnosti nového občanského zákoníku jsme tak byli svědci nastalé dvojkolejnosti náhrady nemajetkové újmy, kdy v oblasti občanského práva postupovaly soudy dle vlastního uvážení, resp. podle Metodiky s hodnotou bodu cca 250 Kč, zatímco v oblasti pracovního práva nadále rozhodovaly o výši bolestného a ztížení společenského uplatnění podle náhradové vyhlášky s hodnotou bodu 120 Kč.

Zákonodárce konečně přistoupil k řešení otázky náhrady újmy způsobené pracovním úrazem a nemocí z povolání prostřednictvím novely zákoníku práce provedené zákonem č. 250/2015 Sb., která nabyla účinnosti k 1. 10. 2015. Novela mimo jiné definitivně upřednostnila náhradu nemajetkové újmy vzniklé v pracovněprávních vztazích v rámci soukromého práva, když zrušila zákon o úrazovém pojištění a zmocnila vládu, aby nařízením stanovila výši náhrady za bolest a ztížení společenského uplatnění odpovídající vzniklé újmě. Zákoník práce tak uzavřel pomyslný kruh způsobu stanovení výše náhrady za újmu na zdraví v soukromém právu, když se znovu navrátil ke stanovení výše náhrady za újmu na zdraví podzákonným předpisem vyšlým z pera moci výkonné, ačkoli je tento přístup v přímém rozporu s důvodovou zprávou nového občanského zákoníku.

Přijaté nařizení vlády č. 276/2015 Sb., o odškodňování bolesti a ztížení společenského uplatnění způsobené pracovním úrazem nebo nemocí z povolání (dále jen „nařízení“) vešlo v účinnost ke dni 26. 10. 2015. Nařízení vychází obdobně jako Metodika Nejvyššího soudu k náhradě nemajetkové újmy na zdraví a náhradová vyhláška z bodového hodnocení. Počty bodů pro hodnocení bolesti a ztížení společenského uplatnění způsobené pracovním úrazem a nemocí z povolání jsou uvedeny celkem ve čtyřech 
přílohách. Od Metodiky se nařízení (bez jakéhokoli bližšího odůvodnění) liší jednak fixní hodnotou jednoho bodu, která je stanovena na 250 Kč, a zároveň způsobem výpočtu náhrady ztížení společenského uplatnění, který v Metodice nově vychází z konceptu ztráty životních př́iležitostí, zatímco nařízení si nadále vystačí s bodovým hodnocením.

Zákoník práce $\mathrm{v}$ novelizovaném znění přiznává $\mathrm{v}$ př́ípadě smrti zaměstnance právo pozi̊stalých na jednorázové odškodnění, konkrétně manželovi, partnerovi a nezaopatřenému dítěti, a to každému ve výši nejméně 240.000 Kč. Jednorázové odškodnění př́ísluši i rodičům zaměstnance, pokud s ním žili v domácnosti, a to v úhrnné výši nejméně 240.000 Kč. Oproti úpravě občanskoprávní je pracovněprávní úprava jednorázového odškodnění nedůvodně restriktivnější, a to především co do okruhu oprávněných. Dítě je oprávněným pouze, pokud splňuje podmínku nezaopatřenosti, rodiče musí splnit podmínku společné domácnosti a zákoník práce vůbec nepočítá s odčiněním újmy osoby blízké.

Přestože služební zákon odkazuje na úpravu náhrady nemajetkové újmy zaměstnance, není ani tato delegace s ohledem na existující otázky a často nedůvodné rozdíly pracovněprávní a občanskoprávní úpravy samospásná. Ačkoli již nejsou rozdíly mezi systémem náhrady újmy založeným obecnou úpravou občanskoprávní a úpravou pracovněprávní tak markantní jako dříve, dvojkolejnost nadále pokračuje. Ústavní soud shledal nařízení problematickým zejména tím, že nerespektuje přinejmenším ve vztahu k odčinění ztížení společenského uplatnění systém stanovení náhrad podle Metodiky, ale především opomíjí premisu rekodifikovaného civilního soukromého práva, totiž že rozhodovací činnost soudů při stanovení konkrétních částek odčinění je třeba oprostit od vlivu moci výkonné, která není oprávněna limitovat soudy v přiznání spravedlivé a dostatečné náhrady.

Z výše uvedeného je patrné, že hmotněprávní úprava zákoníku práce týkající se odčinění nemajetkové újmy vzniklé v souvislosti s výkonem závislé práce vyvolává řadu otázek, na které by mohla poskytnout odpověd’ budoucí relevantní judikatura. Budou-li nicméně mít soudy vůli určitým způsobem sjednotit náhradu nemajetkové újmy v rámci civilního práva, nezbude jim nic jiného, než opětovně aktivovat čl. 95 odst. 2 Ústavy, který jediný jim v současné chvíli v pracovněprávních sporech otevírá cestu k volné úvaze při určování výše náhrady za nemajetkovou újmu.

Zatímco v oblasti soukromoprávní náhrady nemateriální újmy lze za neutěšenou považovat otázku hmotněprávní (tj. ,kolik“ bude plněno), procesní stránka věci zůstává stabilní, nebot' př́slušný bude k rozhodování o př́ípadném sporu obecný soud žalovaného a řízení bude vedeno podle pravidel zákona č. 99/1963 Sb., občanský soudní řád. V př́padě odpovědnostních nároků souvisejících se státní službou je kontroverzní jak otázka hmotněprávní (,kolik“ bude plněno), což je dáno prímou vazbou na zákoník práce, tak i otázka procesní (tj. „kdo“ je orgánem př́slušným k rozhodování o př́ípadných sporech).

V souvislosti s analýzou úpravy nemajetkové újmy v rámci služebních vztahů si nelze odpustit drobnou poznámku stran terminologie použité $\mathrm{v}$ zákoně o státní službě. Novela zákoníku práce provedená zákonem č. 205/2015 Sb. přizpůsobila s účinností k 1. 10. 2015 dosavadní terminologii obsaženou v části jedenácté zákoníku práce, která upravovala náhradu škody, pojmosloví užívanému v novém občanském zákoníku. Na- 
dále se tedy nehovoří o „náhradě škody“, ale o „náhradě škody a nemajetkové újmy“ a termín „odpovědnost za škodu“ byl nahrazen „,povinností k náhradě škody“. Uvedené však nebylo v zákoně o státní službě nijak reflektováno. Logickým výkladem je nutné dojít k závěru, že pokud zákon o státní službě používá pouze termín „škoda“ a současně odkazuje na úpravu v zákoníku práce, škodou dle zákona o státní službě nemůže být myšlena pouze majetková újma (ve smyslu legislativní zkratky uvedené v ust. § 249 odst. 1 zákoníku práce), ale rovněž újma nemajetková. $Z$ uvedených důvodů je nutné „odpovědnost za škodu“ dle zákona o státní službě vykládat jako „povinnost k náhradě škody a nemajetkové újmy“ ve smyslu obecného civilistického pojmosloví, se kterým bude níže $\mathrm{v}$ textu pracováno.

Klíčovou otázkou, která v souvislosti s problematikou povinnosti k náhradě újmy podle části šesté zákona o státní službě vyvstala, je otázka povahy odpovědnostního vztahu odvislého od výkonu služby. Pro účely překládaného př́íspěvku bude níže analyzována pouze dílčí část odpovědnostních vztahů souvisejících s výkonem služby, a to povinnost služebního úřadu $\mathrm{k}$ náhradě nemajetkové újmy při pracovním úrazu či nemoci z povolání státního zaměstnance. Stran povahy uvedeného vztahu existují dva protichůdné názory implikující dvě varianty řešení:

1. Rozhodování o povinnosti k náhradě újmy na straně státního zaměstnance je jedním z druhů rízení ve věcech služby, tj. zvláštního správního řízení, nebot' ačkoli se jedná o odpovědnostní vztah mezi služebním úruadem a státním zaměstnancem, rozhoduje se ve věci služebního poměru;

2. Povinnost k náhradě újmy v rámci zákona o státní službě s ohledem na př́mý odkaz na zákoník práce má být rozhodována pouze $\mathrm{v}$ soukromoprávním režimu a př́ípadné spory z těchto vztahů vzniklé mají být řešeny před civilním soudem.

Zákon o státní službě obsahuje v ust. § 159 odst. 1 výčet rozhodnutí, na která se vztahují ustanovení o rrízení ve věcech služby, přičemž rozhodování o povinnosti k náhradě škody a nemajetkové újmy není v tomto výčtu uvedeno. V následujícím odstavci ust. § 159 zákona o státní službě jsou naopak vymezena rozhodnutí, na která se režim řízení ve věcech státní služby nevztahuje; odpovědnostní vztahy však nejsou uvedeny ani zde. ${ }^{13}$ Tato nedůslednost zákonodárce a mezera v zákoně má významné procesní důsledky.

I přestože vytváří ust. § 159 zákona o státní službě zdání, že oba jeho odstavce obsahují taxativní výčty rozhodnutí, stále silněji byly po přijetí zákona o státní službě slyšet hlasy, podle kterých by měly být odpovědnostní vztahy uznány pod věci služebního poměru, tzn. variantu 1 .

Režimem projednání povinnosti nahradit škodu způsobenou státním zaměstnancem služebnímu úřadu a způsobenou služebním úřadem státnímu zaměstnanci se zabýval Poradní sbor náměstka ministra vnitra pro státní službu, který na svém zasedání dne 3. června 2016 dospěl k závěru, že proces rozhodování o odpovědnosti státního zaměst-

13 Nutno v této souvislosti poznamenat, že formulace, která zakazuje použití ustanovení správního rádu o správním rrízení na rozhodování o vyjmenovaných záležitostech státní služby, nevylučuje použití správního řádu jako takového, ale pouze jeho druhou a třetí část („Obecná ustanovení o správním řízení“ a „Zvláštní ustanovení o správním řízeni““). Vykonává-li správní orgán působnost v oblasti veřejné správy, vztahuje se na jeho postupy správní řád alespoň v části základních zásad činnosti správních orgánů. 
nance nebo služebního úřadu za škodu nebo nemajetkovou újmu podle části šesté zákona o státní službě, je jedním z druhů řízení ve věcech služby. Inspirací mu přitom byla mimo jiné rovněž úprava zákona o služebním poměru př́slušníků bezpečnostních sborů, dle kterého je rozhodování o náhradě škody podřazeno pod režim řízení ve věcech služebního poměru. Podle uvedeného závěru pravomoc rozhodovat o náhradě škody a nemajetkové újmy nemůže být služebním orgánem přenesena na jiné představené, přičemž jiné úkony v řízení mohou ve smyslu ust. § 15 odst. 2 správního řádu provádět úřední osoby $\mathrm{k}$ tomu oprávněné podle služebních předpisů nebo $\mathrm{k}$ tomu pověřené služebním orgánem. ${ }^{14}$

V této souvislosti není bez zajímavosti, že historicky byl vztah právní úpravy řízení ve věcech služebního poměru a obecné úpravy správního řízení jiný, když tehdejší vládní nařízení č. 8/1928 Sb., o řízení ve věcech náležejících do působnosti politických úřadů (správní ř́zení), výslovně ve svém ust. § 1 odst. 2 stanovilo, že se úprava tohoto správního řádu nevztahuje na řízení ve věcech služebního poměru státních zaměstnanců; a ani pozdějšš správní řád se na rozhodování ve věcech služebního poměru, které bylo chápáno jako rozhodování $\mathrm{v}$ jeho interních vztazích nadřízenosti a podřizenosti, nevztahovaly. ${ }^{15}$

Ke zvolenému způsobu a dovozování režimu použitelného na oblast náhrady škody a nemajetkové újmy podle zákona o státní službě lze na tomto místě pouze dodat, že by se s ohledem na právní jistotu adresátů právních norem a jejich potřebnou legitimitu slušelo reflektovat a napravit nalezenou mezeru zákona př́slušnou novelizací, která by doplnila ust. § 159 odst. 1 zákona o státní službě o bod zahrnující oblast náhrady škody. Postavení Poradního sboru náměstka ministra vnitra pro státní službu, povaha a závaznost jeho závěrů pro adresáty právní normy jsou přinejmenším diskutabilní. ${ }^{16}$

V př́ípadě subsumpce odpovědnostních vztahů pod věci služebního poměru, bude o nárocích z nemajetkové újmy státního zaměstnance rozhodovat služební orgán a odkaz ust. § 124 zákona o státní službě na zákoník práce bude fungovat výlučně jako hmotněprávní.

Takové ř́zení bude vedeno podle procesních ustanovení zákona o státní službě, přičemž se v souladu s ust. § 160 zákona o státní službě bude subsidiárně postupovat podle zákona č. 500/2004 Sb., správní rád (dále jen „správní řád“).

Porovnáme-li v základních aspektech rozhodování o náhradě nemajetkové újmy zaměstnance a státního zaměstnance, lze dojít $\mathrm{k}$ následujícím závěrům. $\mathrm{V}$ případě zaměstnance bude o výši náhrady nemajetkové újmy (bolestné, náhrada za ztížení společenského uplatnění aj.) rozhodovat civilní soudce, který disponuje př́slušnou autoritou, je nezávislý a nestranný a tato nezávislost a nestrannost je garantována několika

14 Závěr č. 5 ze zasedání poradního sboru náměstka ministra vnitra pro státní službu k zákonu o státní službě ze dne 3. června 2016.

$15 \mathrm{~K}$ tomu více KOPECKÝ, M. In: PICHRT, J. a kol. Zákon o státní službě. Komentářr. 1. vyd. Praha: Wolters Kluwer, 2015.

16 V českém právním řádu bohužel není tento typ „dotváření zákonư“ mocí výkonnou ojedinělý. Vzpomeňme např́íklad na Společné stanovisko Ministerstva práce a sociálních věcí a Ministerstva zdravotnictví ze dne 28. 1.2014 k postupu při odškodňování pracovních úrazů a nemocí z povolání po nabytí účinnosti nového občanského zákoníku, ve kterém bylo ve dvou odstavcích konstatováno, že se nadále postupuje podle (v té době již zrušené) náhradové vyhlášky. 
ústavněprávními instrumenty, je vázaný pouze zákonem a mezinárodní smlouvou ve smyslu čl. 95 Ústavy, má vysokoškolské právní vzdělání, justiční zkoušku a stojí za ním rozsáhlá judikatura; řízení bude ovládáno zásadou dispoziční, zásadou veřejnosti, principem rovnosti a právem na spravedlivý proces. Naproti tomu v př́padě státního zaměstnance bude o výši náhrady nemajetkové újmy (bolestné, náhrada za ztížení společenského uplatnění aj.) rozhodovat služební orgán, na jehož profesní postavení nejsou kladeny ani zdaleka takové nároky jako na soudce. Služební orgán zastupuje v uvedeném řízení služební úřad, což převedeno do vztahů pracovněprávních je obdobné, jako by o výši náhrady nemajetkové újmy zaměstnavatele rozhodoval zaměstnavatel sám. Správní ŕízení bude vedeno zásadou legality a oficiality, zásadou písemnosti, zásadou vyhledávací, zásadou ochrany veřejného a jiného obecného zájmu a v neposlední řadě zásadou neveřejnosti, která ve správních řízeních převažuje.

Řízení o náhradě nemajetkové újmy bude v souladu s principy správního řízení zahajováno z moci úřední, tzn. jakmile se služební orgán dozví o tom, že jsou zde důvody k zahájení rízení. V prípadě nečinnosti služebního orgánu lze postupovat dle úpravy ust. $\S 80$ odst. 2 správního řádu a pravidel ochrany před nečinností. Domáháli se zahájení rízení státní zaměstnanec, je třeba na jeho podání hledět jako na podnět k zahájení rízení ve smyslu ust. § 42 správního řádu. Není vyloučeno, aby ještě před zahájením řízení o náhradě škody došlo k projednání nároků státního zaměstnance (před př́slušnou škodní komisí či mimo ni), jehož výsledkem by mohlo být uzavření dohody o výši škody a způsobu její úhrady. Tato dohoda by s ohledem na ust. § 161 odst. 1 správního řádu splňovala podmínky uzavření veřejnoprávní smlouvy.

Postoupíme-li o pár procesních kroků ve správním řízení vpřed, má státní zaměstnanec právo odvolat se proti rozhodnutí služebního orgánu k nadřízenému služebnímu orgánu. Proti rozhodnutí nadřízeného služebního orgánu bude jako opravný prostředek připadat $\mathrm{v}$ úvahu žaloba proti rozhodnutí správního orgánu ve smyslu ust. § 65 a násl. zákona č. 150/2002 Sb., soudní rád správní17, kdy teprve tehdy se věc dostane k rukám profesionálního soudce. Délka soudních řízení je obecně v České republice velmi vysoká a předcházející správní řízení státnímu zaměstnanci jeho čekání na přiznanou náhradu nemajetkové újmy jistě neukrátí.

Za nejproblematičtější lze však, v případě akceptování konceptu rozhodování o náhradě nemajetkové újmy v intencích správního rrízení, považovat roli správního soudu, která vychází a je poplatná zcela odlišným principům správního soudnictví od soudnictví civilního. Předmětem rozhodování služebního orgánu je konkrétní částka, která bude státnímu zaměstnanci služebním úřadem vyplacena v souvislosti s jeho utrpěným služebním úrazem či nemocí z povolání. Hmotněprávně bude služební orgán nucen aplikovat pravidla zákoníku práce, resp. nařízení vlády č. 276/2015 Sb., o odškodňování bolesti a ztížení společenského uplatnění způsobené pracovním úrazem nebo nemocí z povolání. Částka, ke které služební orgán dojde, je pro státního zaměstnance částkou finální. Správní soud nemá moderační právo a nemůže částku, kterou služební orgán přiznal jakkoli měnit. Primárním účelem správního soudnictví není nalézání práva, ale pouze soudní kontrola veřejné správy, tj. kontrola legitimity a legality rozhodnutí slu-

17 Dále jen „soudní řád správní“ či „SŘS“. 
žebního orgánu. Podstatou řízení o náhradu nemajetkové újmy však není nic jiného než nalézání práva státního zaměstnance na konkrétní výši náhrady. S ohledem na rozsah tohoto př́íspěvku navíc pomineme absurdní důsledky, ke kterým může dojít $\mathrm{v}$ případě aplikace ust. $\S 165$ zákona o státní službě, podle něhož může být vydání rozhodnutí prvním úkonem v řízení.

\section{NÁHRADA NEMAJETKOVÉ ÚJMY PŘÍSLUŠNÍKA BEZPEČNOSTNÍCH SBORU゚ PODLE ZÁKONA O SLUŽEBNÍM POMĚRU PŘÍSLUŠNÍKŮ BEZPEČNOSTNÍCH SBORŮ}

Následující část př́spěvku je věnována náhradě nemajetkové újmy podle zákona o služebním poměru př́íslušníků bezpečnostních sborů, kde bude opět hlavní pozornost věnována povinnosti bezpečnostního sboru $\mathrm{k}$ náhradě škody a nemajetkové újmy vzniklé př́islušníkovi služebním úrazem či nemocí z povolání.

Zákon o služebním poměru př́slušníků bezpečnostních sborů upravuje vztahy vyplývající a související se služebním poměrem komplexně a marně bychom $\mathrm{v}$ jeho textu hledali jakýkoli odkaz na zákoník práce či správní ráa. Nejvyšší správní soud nicméně ve své rozhodovací praxi dovodil, že přestože zákon vztah úpravy o řízení ve věcech služebního poměru ke správnímu rrádu zákon neřeší, obecná úprava správního řízení podle správního řádu se použije subsidiárně i na řízení ve věcech služebního poměru př́slušníků bezpečnostních sborů, nebot' použití obecné úpravy není zákonem vyloučeno. ${ }^{18}$

Odpovědnostní vztahy odvislé od služebního poměru upravuje zákon v části sedmé, prričemž ohledně terminologie platí to samé, co bylo výše uvedeno u zákona o státní službě, terminologie nekoresponduje s novým soukromým právem, nicméně pro zachování přehlednosti a celistvosti textu bude nadále pracováno s rekodifikovaným pojmoslovím.

Úprava povinnosti k náhradě škody a nemajetkové újmy v zákoně o služebním poměru př́ślušníků bezpečnostních sborů relativně koresponduje s úpravou v zákoníku práce. $\mathrm{V}$ př́padě bolesti a ztížení společenského uplatnění má př́slušník nárok na jednorázovou náhradu, jejíž výši stanoví v souladu se zákonným zmocněním v ust. § 104 odst. 2 vyhláškou Ministerstvo vnitra v dohodě s Ministerstvem financí, Ministerstvem spravedlnosti a zpravodajskými službami. Vyhláška č. 277/2015 Sb., o postupu při určování výše náhrady za bolest a za ztížení společenského uplatnění př́slušníků bezpečnostních sborů, byla prrijata 26. 10. 2015 a je poslední vyhláškou provádějící uvedené ustanovení zákona. Při srovnání zmíněné vyhlášky a nařízení vlády č. 276/2015 Sb., o odškodňování bolesti a ztížení společenského uplatnění způsobené pracovním úrazem nebo nemocí z povolání, které provádí totožnou oblast zákoníku práce, je patrné, že byly obě úpravy přijaty současně a ve způsobu výpočtu odčinění za bolest a ztížení společenského uplatnění se zcela shodují. Vyhláška také vychází z bodového systému

18 K tomu srov. Rozsudek Nejvyššího správního soudu ze dne 22. ledna 2014, sp. zn.: 3 Ads 117/2012. 
jak pro účely odčinění bolestného, tak i pro odčinění ztížení společenského uplatnění. Hodnota bodu je stanovena fixní částkou 250 Kč. ${ }^{19}$

Jednorázové odškodnění pozůstalých se v souladu s ust. § 109 odst. 1 zákona o služebním poměru příslušníků bezpečnostních sborů v případě smrti př́slušníka poskytne pozůstalému manželovi př́slušníka a nezaopatřenému dítěti, a to každému ve výši 400000 Kč, a každému rodiči příslušníka, jestliže s ním žil v domácnosti, ve výši 240000 Kč. Je patrné, že okruh oprávněných osob je v porovnání s okruhem oprávněných osob stanovených $\mathrm{v}$ zákoníku práce, jehož ustanovení se použijí pro služební poměr státních zaměstnanců, užšíi ${ }^{20}$, nicméně co do své výše odškodnění téměř dvojnásobně přesahuje výši jednorázového odškodnění stanoveného v ust. § 271i odst. 1 zákoníku práce. Orgán př́slušný k rozhodnutí o výši jednorázového odškodnění zde sice nemá, na rozdíl od občanskoprávní či pracovněprávní úpravy možnost úvahy, nebot' částky jednorázového odškodnění pozůstalých jsou stanoveny fixně bez ohledu na konkrétní okolnosti případu, nicméně zákon o služebním poměru příslušníků bezpečnostních sborů obsahuje v ust. § 109 odst. 2 valorizační formuli, která ukládá jednorázové odškodnění pozůstalých každoročně zvýšit v poměru k navýšení průměrné měsíční mzdy v nepodnikatelské sféře dosažené podle zveřejněných údajů Českého statistického úrúadu za předminulý kalendářní rok.

Stejně jako zákoník práce i zákon o služebním poměru př́slušníků bezpečnostních sborů výslovně obsahuje zvláštní úpravu odpovědnosti bezpečnostního sboru za jinou škodu na zdraví př́slušníka, než je škoda vzniklá služebním úrazem nebo nemocí z povolání. Pro způsob a rozsah náhrady platí ustanovení o služebním úrazu s tím omezením, že nevzniká nárok na jednorázové odškodnění a jednorázové odškodnění pozůstalých.

Rozhodování ve věcech náhrady škody týkající se příslušníkủ bezpečnostních sborů je podřazeno pod režim řízení ve věcech služebního poměru. ${ }^{21}$ Zákon o služebním poměru př́slušníků bezpečnostních sborů v ust. § 171 stanoví pouze negativní výčet druhů rozhodnutí, v nichž se nevede řízení ve věcech služebního poměru, a contrario proto o věcech $\mathrm{v}$ tomto ustanovení neuvedených, mezi které patří i odpovědnostní vztahy, rozhoduje služební funkcionář.

Řízení ve věcech služebního poměru upravuje zákon v ust. § 169 a násl. komplexně. Řízení je zahájeno na žádost účastníka nebo z podnětu bezpečnostního sboru dnem, kdy je žádost účastníka doručena věcně př́slušnému služebnímu funkcionáři, nebo služební funkcionář učiní první úkon vi̊či účastníku, jestliže se zahajuje řízení z podnětu bezpečnostního sboru. V otázce jednotlivých limitů a rizik řízení platí obdobné, co bylo řečeno výše u řízení ve věcech služebních poměrů státních zaměstnanců.

19 K tomu srov. ust. § 7 odst. 2 vyhlášky č. 277/2015 Sb., o postupu při určování výše náhrady za bolest a za ztížení společenského uplatnění př́islušníků bezpečnostních sborů.

20 Okruh pozůstalých oprávněných $\mathrm{k}$ jednorázovému odškodnění pro př́ípad smrti př́islušníka nepamatuje na rozdíl od pracovněprávní úpravy na registrovaného partnera př́slušníka.

21 K tomu srov. Rozsudek Nejvyššího správního soudu ze dne 10. července 2013, sp. zn.: 4 Ads 2/2013. 


\section{NÁHRADA NEMAJETKOVÉ ÚJMY PODLE ZÁKONA O ZAHRANIČNÍ SLUŽBĚ}

Jako tzv. ,ještě teplý، bychom mohli označit zákon o zahraniční službě, který byl do českého právního řádu přijat poměrně nedávno. Tento zákon má plnit funkci základního právního předpisu, který uceleným způsobem vymezí na jedné straně základní pravidla a zásady výkonu zahraniční služby jako specifické činnosti státní správy, a dále nastaví zvláštní pravidla pro vnitřní organizaci státní služby vykonávané v Ministerstvu zahraničních věcí, zohledňující specifický charakter služby, resp. práce vykonávané v rámci zahraniční služby. Účelem zákona je zajistit nezbytnou právní úpravu zahraniční služby jako státní služby sui generis a vytvořit základní předpoklady pro její optimální výkon. Jedním z cílů zákona o státní službě bylo zvýšení právní jistoty státních zaměstnanců a zaměstnanců vykonávajících zahraniční službu, včetně možnosti profesionálního růstu, a dále umožnění nastavení stabilních podmínek v rámci Ministerstva zahraničních věcí pro řádné fungování zahraniční služby. ${ }^{22}$

Vztah k dalším právním předpisům upravuje zákon o zahraniční službě, když ve svém ust. $§ 58$ odst. 1 stanoví subsidiární působnost zákona o státní službě pro služební vztahy upravené zákonem o zahraniční službě a subsidiární působnosti zákoníku práce pro pracovněprávní vztahy upravené v zákoně o státní službě. V obou př́ípadech lze konstatovat, že hmotněprávní těžiště právní úpravy náhrady nemajetkové újmy bude s ohledem na delegační princip zakotvený v zákoně o státní službě, ležet v části jedenácté zákoníku práce.

Speciální úpravu stanoví zákon o zahraniční službě v oblasti náhrady nemajetkové újmy pro př́ípad přiznání invalidního důchodu diplomatickému, administrativnímu nebo technickému pracovníkovi, který vykonával službu nebo práci v zahraničí. V př́ípadě invalidity prvního nebo druhého stupně, ke které došlo v důsledku mimořádné události či trestného činu v přijímajícím státě, přiznává zákon jednorázové odškodnění ve výši šestinásobku průměrného měsíčního platu pracovníka; v prŕípadě přiznání invalidního důchodu pro invaliditu třetího stupně náleží takovému pracovníkovi jednorázové odškodnění ve výši desetinásobku průměrného měsíčního platu pracovníka. Totožný nárok má člen rodiny, který diplomatického, administrativního nebo technického pracovníka doprovází.

Zákon o zahraniční službě dále přiznává jednorázové odškodnění pozůstalému manželovi, partnerovi a nezaopatřenému dítěti, a to každému ve výši dvacetinásobku průměrného měsíčního platu diplomatického, administrativního nebo technického pracovníka $\mathrm{v}$ případě jeho úmrtí, které nastalo $\mathrm{v}$ důsledku mimořádné události nebo trestného činu v zahraničí. ${ }^{23}$

22 Podrobněji ohledně okolnosti, důvodů a cílů zákona v Důvodové zprávě k zákonu č. 150/2017 Sb. Parlament České republiky, Poslanecká sněmovna, 7. volební období, 2013-2017, tisk 994/0.

23 Důvodová zpráva k zákonu o zahraniční službě uvádí, že Ministerstvo zahraničních věcí vyplácí náhradu nákladů na výživu pozůstalých v důsledku vedoucího zastupitelského úřadu, který se stal obětí teroristického činu, celkem 270000 Kč ročně. Zákon o zahraniční službě by pro tento př́ípad přiznal pozůstalým rovněž jednorázové odškodnění ve výši dvacetinásobku průměrného měsíčního platu, které by s ohledem na zařazení vedoucího zastupitelského úřadu v nejvyšším platovém stupni 15. platové tř́idy činilo 743200 Kč. 


\section{ZÁVĚREM}

Cílem tohoto prríspěvku bylo nastínit jednotlivé př́stupy k problematice náhrady nemajetkové újmy $\mathrm{v}$ rámci vybraných dalších právních vztahů účasti na práci, se zaměřením na služební vztahy. V této souvislosti je znovu nutné zdůraznit, že oblasti náhrady nemajetkové újmy by v rámci zvýšení systematičnosti a přehlednější orientaci v př́slušných právních předpisech, slušelo určité sjednocení, alespoň v podzákonných právních předpisech, když vyhláška č. 277/2015 Sb., o postupu při určování výše náhrady za bolest a za ztížení společenského uplatnění př́slušníkủ bezpečnostních sborů spolu s nařízením vlády č. 276/2015 Sb., o odškodňování bolesti a ztížení společenského uplatnění způsobené pracovním úrazem nebo nemocí z povolání, obsahují zcela identické obodování jednotlivých zranění při určování výše bolestného a ztížení společenského uplatnění.

Rozpory mezi jednotlivými systémy náhrad nemajetkové újmy, na které prŕspěvek upozornil, jsou o to bizarnější, pokud si uvědomíme, že jak v př́ípadě nemajetkové újmy zaměstnance, tak v př́ipadě nemajetkové újmy státního zaměstnance, se jedná o vztahy odvozené od výkonu závislé práce. To vše při vědomí, že stejným jmenovatelem v každém systému náhrady nemajetkové újmy zůstává určení hodnoty zdraví konkrétního člověka.

Mgr. Lucie Matějka Řehořová

Právnická fakulta Univerzity Karlovy

lucie.rehorova@seznam.cz 



\title{
VYBRANÁ SPECIFIKA PRACOVNĚPRÁVNÍCH SPORŮ V ZAHRANIČNÍM SROVNÁNÍ
}

\author{
PATRIK STONJEK
}

\begin{abstract}
Selected specifics of labour law disputes in international comparation
In the submitted text, the author attempts to present some chosen specifics of labour law disputes with a view to differences in court procedure. The author focuses more detailed on composition of labour courts/senates by lay judges and on their role by decision-making of labour law disputes and on financial demands of litigation of labour law disputes before courts.
\end{abstract}

Keywords: labour law disputes; court procedure; lay judges; court costs

Klíčová slova: pracovněprávní spory; soudní proces; př́isedící; náklady soudního řízení

DOI: $10.14712 / 23366478.2019 .10$

\section{ÚVOD}

Pracovněprávní vztahy jsou na rozdíl od jiných občanskoprávních nebo obchodněprávních vztahů jedinečné. Tato jedinečnost spočívá v délce a intenzitě jejich trvání, kterou lze srovnávat pouze s rodinnými vztahy. Z toho důvodu by měl zákonodárce zajistit, aby v pracovněprávních vztazích vznikalo co nejméně konfliktů. Vyvstalé spory by pak měly být řešeny rychle a efektivně a měly by vést $\mathrm{k}$ usmírení jejich stran, a to nejlépe za účelem jejich další spolupráce. ${ }^{1}$

Specifičnost pracovněprávních vztahů odůvodňuje zvláštní právní úpravu soudního procesu, jehož předmětem tyto vztahy jsou. V kontinentální i anglosaské právní kultuře je takovýchto odlišností mnoho. Jedná se např. o existenci zvláštní soudní soustavy nebo specializovaných senátů obecných soudů, účast laiků na rozhodování soudů, zvýhodnění při placení soudních poplatků, kratší lhůty pro rozhodování v pracovněprávních věcech, nevázanost soudu uplatněným návrhem, uplatnění zásady vyšetřovací, omezení koncentrace řízení, otočení důkazního břemene, zvláštní pravidla u náhrady nákladů soudního řízení v př́ípadě podání neúspěšné/ho žaloby/návrhu, speciální úpra-

* Autor je advokátním koncipientem a interním doktorandem na katedře pracovního práva a práva sociálního zabezpečení na Právnické fakultě Univerzity Karlovy.

1 Srov. MORGENWECK, J. Die Arbeitsgerichtsbarkeit in England. Frankfurt am Mein: Petr Lang, 2013, 156 s. ISBN 978-3-631-62756-3, s. 7. 
vu vykonatelnosti rozhodnutí soudů v pracovněprávních věcech nebo odlišné důvody umožňující využití rádných i mimořádných opravných prostředků.

Český právní řád mnoho specifik soudního procesu, jehož předmětem jsou pracovněprávní věci, neobsahuje. S výjimkou senátů, které rozhodují pracovněprávní spory v prvním stupni, lze zmínit ,zastoupení cizinců právnickou nebo fyzickou osobou sledujicich ochranu jejich práv; není nutné skládat jistotu spolu s návrhem na vydání predběžného opatření; je předpokládán zvláštní režim pro hodnoceni di̊kazů ohledně tvrzení, že došlo k př́mé nebo nepřimé diskriminaci; pro část pracovní odměny je upravena predběžná vykonatelnost"; u peněžitých plnění se neuplatní omezení př́ípustnosti dovolání. ${ }^{2}$ Vlastní průběh soudního rrízení v pracovněprávních věcech se tak v podstatě téměř vůbec neliší od klasického soudního řízení. V minulosti tomu tak však nebylo. ${ }^{3}$

V následujícím textu se budu věnovat vybraným odlišnostem pracovněprávních sporů vedených před soudy. Zejména budou představeny ty, které český právní řád nezná (resp. zná, ale v jiné podobě). Krátce budou okomentovány i odlišnosti spíše společenského charakteru, a to ve Spolkové republice Německo a v Rakouské republice, které utvářejí tamní pracovněprávní soudní proces (dále též jako ,„pracovněprávní proces").

\section{LAICKÝ PRVEK V PRACOVNĚPRÁVNÍM SOUDNÍM PROCESU}

Nejviditelnějším projevem jedinečnosti pracovněprávního procesu v České republice je existence soudního senátu před soudem prvního stupně, který je složen z jednoho soudce a dvou př́sedících - soudců z lidu. Jedná se o realizaci možnosti, která je uvedená v čl. 94 Ústavy, aby se na rozhodování soudů podíleli vedle soudců i další občané. Soudcům z lidu se věnoval již Václav Hora ${ }^{4}$ v publikaci Československé právo procesní, uvádějíc: „Ovšem ale sluši s důrazem upozorniti na jednu věc. Tento názor o spolupůsobení soudců z lidu při výkonu soudnictví předpokládá jen takové soudce z lidu, kteři by svými znalostmi životními zaručovali splnéní toho, co by bylo lze od nich pro zlepšeni soudnictvi podle shora naznačeného očekávati, a kteři by při tom byli proniknuti poctivou snahou, dopomáhati $k$ vitězství jen pravdě, spravedlnosti, naprostou nestranností a úzkostlivou svědomitostí, kteř́ by nespatrovali ve svém úradě ani nepohodlné bremeno ani vhodný plášt' pro uplatňování svého stranictvi (at'v jakémkoli směru), nýbrž jen a jen nejvyšší, ale i nejodpovědnějši poctu občanskou. K tomu bude zapotrebi ještě dlouholeté výchovy občanské. “ Tomuto historickému ${ }^{5}$ pojetí prrísedícího odpovídá i současný $§ 60$ odst. 1 zákona č. 6/2002 Sb., o soudech a soudcích, (dále též

2 HROMADA, M. Pracovněprávní spory. 1. vyd. Praha: C. H. Beck, 2015, 214 s. ISBN 978-80-7400-581-7. S. VII.

3 K historii pracovněprávního soudnictví viz např. PIRCHT, J. - ŠTEFKO, M. - MORÁVEK, J. Analýzy alternativnich zpi̊sobů řě̌eni sporů v pracovněprávních vztazich. Praha: Wolters Kluwer, 2016, 407 s. ISBN 978-80-7552-138-7, s. 118 a následující.

4 HORA, V. Československé právo procesní. I.-III. díl. Praha: Wolters Kluwer ČR, 2010, ISBN 978-807357-540-3. Díl. I., s. 65.

5 Citované dílo Václava Hory pochází z roku 1934. 
jako „ZoSaS“), který jako podmínky vzniku výkonu funkce př́isedícího stanovuje státní občanství České republiky, svéprávnost, bezúhonnost, věk nejméně 30 let a zkušenosti a morální vlastnosti, zaručující rádné zastávání funkce. Odbornost není (bohužel) v současné době po príísedících vyžadována. ${ }^{6}$

Přísedící jsou voleni zastupitelstvy obcí (v Praze zastupitelstvy městských částí) v obvodu prŕslušného okresního (v Praze obvodního) soudu (§ 64 odst. 2 zákona o soudech a soudcích). Kandidáti do funkce přísedících, kterými mohou být pouze občané mající trvalý pobyt nebo pracující v obvodu zastupitelstva, jímž jsou do funkce voleni, jsou navrhováni členy príslušného zastupitelstva s tím, že zastupitelstvo si k navrženým kandidátům vyžádá vyjádření předsedy př́slušného soudu. ${ }^{7}$ Jednotliví kandidáti do funkce př́isedících jsou tak z hlediska jejich zkušeností a morálních vlastností hodnoceni $\mathrm{v}$ podstatě pouze členy př́slušného zastupitelstva a předsedou př́slušného soudu. Ostatní osoby se k nim mohou vyjádřit toliko za situace, že se dostaví na schůzi zastupitelstva, kde se o jednotlivých kandidátech bude hovořit. ${ }^{8}$

Zásadním nedostatkem u př́sedících je již zmíněný chybějící požadavek na jejich odborné znalosti z pracovněprávní praxe, které by z nich činily cenné pomocníky při rozhodování pracovněprávních sporů, jejichž znalosti nejsou (pouze) teoretické, ale především praktické. ${ }^{9}$ Jmenované kritérium obsahuje německý zákon o pracovních soudech z roku $1953^{10}$ (dále též jako „ArbGG“) toliko u přísedících, kteří působí u Spolkového pracovního soudu ${ }^{11}$, nicméně z vlastní zkušenosti ${ }^{12}$ mohu říct, že i př́ísedící (tzv. čestní soudci - ehrenamtliche Richter ${ }^{13}$ ), kteří jsou činní na nižších soudních instancích, tedy na pracovních a zemských pracovních soudech, velice solidními znalostmi z pracovněprávní praxe skutečně disponují. K čestným soudcům Bader ${ }^{14}$ uvádí: „Čestní soudci mají vnést do výkonu soudni pravomoci jejich zvláštni odbornost. ${ }^{15}$ Proto je chybné nazývat čestné soudce v sociálním a pracovním soudnictví jako, laické soudce; nejedná se totiž pouze o ctihodné občany, u kterých se pořadí výběru určuje losem (jako o porotců/soudců z lidu), ale o ženy a muže, kteři byli navrženi právě kvi̊li jejich odbor-

6 Srov. WINTEROVÁ, A. - MACKOVÁ, A. a kol. Civilní právo procesní. Prvni část- Řizení nalézací. Praha: Linde, 2014, 624 s. ISBN 978-80-7201-940-3, s. 124.

7 Viz $§ 64$ odst. 3 a 4 ZoSaS.

8 K délce funkčního období, skládání slibu atp. viz $§ 60$ a násl. zákona o soudech a soudcích.

9 Srov. PICHRT, J. - ŠTEFKO, M. - MORÁVEK, J. Analýzy alternativnich způsobů re rěeni sporů v pracovněprávnich vztazich. S. 194.

10 V originále se jedná o Arbeitsgerichtsgesetz, který je dostupný na: <www.gesetze-im-internet.de> [cit. 14. 11. 2018].

11 Viz $§ 43$ odst. 2 věta druhá ArbGG. S ohledem na to, že se jedná o jednu z nutných podmínek pro výkon funkce př́ísedícího u Spolkového pracovního soudu, mohlo by být $\mathrm{v}$ př́ípadě jejího nedostatku zahájeno řízení o zbavení funkce př́isedícího, který by zvláštními znalostmi a zkušenosti nedisponoval (srov. LIEBSCHER, in SCHWAB, N., WETH, S., a kol. Kommentar zum Arbeitsgerichtsgesetz. 2 Auflage. Köln: Verlag Dr. Otto Schmidt KG, 2007, 2682 s. S. 755, m. č. 9.).

12 Jedná se o zkušenosti nabyté na stáži absolvované na Pracovním soudu v Münsteru a Zemském pracovním soudu v Hammu.

13 Ačkoliv není zcela správné nazývat německé čestné pracovněprávní soudce českým pojmem přisedící, budu tak i nadále činit, a to $\mathrm{z}$ toho důvodu, aby nedocházelo $\mathrm{k}$ matení čtenářů.

14 BADER, in BADER, P. - HOHMANN, R. - KLEIN, H. Die ehrenamtlichen Richterinnen und Richter in der Arbeits- und Sozialgerichtsbarketi. 13. neu bearbeitete und erweiterte Auflage. Heidelberg: C. F. Müller, 2012, 315 s. ISBN 978-3-8114-7014-9. S. 1.

15 Zde cituje shora jmenovaný autor Liebschera (LIEBSCHER, in SCHWAB, WETH, § 6 Rn. 48). 
nosti ${ }^{16}$. Na jiném místě Bader zdůrazňuje, že pracovněprávní proces není od začátku a dnes ještě víc myslitelný bez odborného porozuměni prísedícich. Toto odborné porozumění se ovšem nevztahuje na to, že přisedící jsou znalejši práva než soudci. Odborné porozuměni, které bylo jmenováno na tomto mistě, se právě prednostně neodvozuje od odborných znalostí práva, ale vztahuje se na reálné zkušenosti a znalosti dění v provozu, závodu, hospodáŕství a pracovním životè.."17

Odbornost př́isedících je implicitním požadavkem výkonu jejich funkce na všech soudních instancích v Rakouské republice, viz § 10 odst. 2 zákona o pracovních a sociálních soudech z roku $1985^{18}$ (dále též jako „ASGG“), který hovoří o odborných laických soudcích ${ }^{19}$ (fachkundige Laienrichter). Jejich významnou úlohu vyzdvihuje např. Neumayr ${ }^{20}$, která poznamenává, že „důležitý úkol odborných laických soudců spočivá $v$ poskytnutí jejich zvláštnich odborných znalost ${ }^{21}$, ale také ve zvýšení akceptace rozhodnuti pracovnich a sociálnich soudư “22.

Německy mluvící odborná veřejnost se tak jednoznačně shoduje na přínosu přísedících v pracovněprávních sporech, a to zejména s ohledem na jejich odborné znalosti. Tento názor je ale sdílen i za hranicemi Rakouské republiky nebo Spolkové republiky Německo, a to ve Francii a Spojeném království Velké Británie a Severního Irska. Potvrzují jej rozhovory, které byly vedeny výzkumníky s tamními př́sedícími a soudci. ${ }^{23}$

U českých soudů mám velmi často pocit, že přísedící v pracovněprávních věcech nejsou dostatečně motivovaní, diplomaticky řečeno. ${ }^{24}$ Při jednáních působí mnohdy nepř́tomně, čímž vyvstávají otázky, jestli jsou př́nosem pro pracovněprávní soudnictví. Navíc se mnohdy jedná o osoby důchodového věku, o jejichž znalostech pracovního prostředí tržní ekonomiky je možné přinejmenším pochybovat. ${ }^{25}$

16 Na tomto místě pak shora uvedený autor odkazuje na judikaturu německého ústavního soudu, a to např na jeho rozhodnutí BVerfG ze dne 22. 1. 1959 - 1 BvR 154/55 - BVerfGE 9 nebo ze dne 4. 6. 1969 2 BvR 412/66, a na další rozhodnutí německých nejvyšších soudů.

17 BADER, in BADER, P. - HOHMANN, R. - KLEIN, H. Die ehrenamtlichen Richterinnen und Richter in der Arbeits- und Sozialgerichtsbarketi. S. 3.

18 V originále se jedná o Arbeits- und Sozialgerichtsgesetz, který je dostupný na www.ris.bka.gv.at [cit. 17. 11. 2018].

19 I v př́ípadě rakouských čestných soudců budu dále v textu používat český pojem př́isedící.

20 NEUMAYR, in NEUMAYR, M. - REISSNER, G., P. Zeller Kommentar zum Arbeitsrecht. 3. Auflage. Wien: MANZ Verlag Wien, 2018, 3860 s. ISBN 978-3-214-03821-2. § 10, m. č. 3.

21 Zde cituje výše uvedený autor Kudernu (KUDERNA, ASGG 109).

22 Na tomto místě pak shora jmenovaný autor odkazuje na Kurase (KURAS, ZAS 2012, 321), Haidera (HAIDER, Wohltat 182) nebo Greifenedera (GREIFENEDER, ZAS 2012, 321).

23 BUGERSS, P., et al. The roles, resources and competencies of employee lay judges. A cross-national study of Germany, France and Geat Britain. Düsseldorf: Hans-Böckler-Stiftung, 2017, 92 s. ISSN 2509-2359. S. 6. Podobné rozhovory jsem také vedl, a to s německými a rakouskými soudci a príísedícími, a mohu vše, co bylo uvedeno výše, potvrdit.

24 Srov. PICHRT, J. - ŠTEFKO, M. - MORÁVEK, J. Analýzy alternativnich způsobi̊ řešeni sporů v pracovněprávnich vztazich. S. 194.

25 V prosinci roku 2017 působilo na Městském soudu v Brně, na Obvodním soudu pro Prahu 9 a na Okresním soudu v Karviné, Liberci, Náchodě, Nymburce, Pelhřimově a Tachově celkem 115 př́sedících v pracovněprávních věcech, jejichž průměrný věk byl 63 let. $Z$ toho byli pouze 4 př́isedící ve věku $31-40$ let a 37 př́sedících ve věku 71 a více let. Nejvyšší průměrný věk přísedících vykazoval Okresní soud v Náchodě, a to 71 let. Okresního soud v Pelhřimově byl naopak obsazen nejmladšími př́sedícími, kterým bylo v průměru 58 let. Tato data mi byla v citovaném období poskytnuta jmenovanými soudy. 
Věk ale zcela jistě není překážkou toho, aby mohl přísedící dobře vykonávat svou funkci. Setkal jsem se s př́sedícím, kterému bylo více než 90 let, ale který svými faktickými, ale i právními znalostmi pracovněprávního prostředí a pracovního práva převyšoval mnoho (možná i většinu) osob živících se právem, které znám; nutno dodat, že jeho praxe (jakožto laika) u soudů čítala více než 35 let. Jednalo se však o jediného př́sedícího, se kterým jsem se dosud v České republice potkal, který by pokládal dotazy i během samotného soudního jednání. I v tomto jsou němečtí nebo rakouští príísedící mnohem aktivnější, což minimálně vyvolává během soudního jednání dojem, že (1) sledují př́ípad a (2) že mu rozumí, příp. se jej snaží pochopit. Jednou jsem se v Německé spolkové republice setkal s př́ísedícím, který byl natolik horlivý, že během soudního jednání přerušil soudkyni slovy „počkejte, počkejte“. ${ }^{26}$ To je samožrejmě věc, která by se stávat neměla, protože snižuje autoritu soudce před účastníky soudního jednání a může i narušit jeho průběh. I navzdory tomu ale zastávám názor, že dotazy př́sedících ke skutkovým otázkám případů jsou na místě, protože se jedná o oblast, kde praktická znalost prrísedících pracovního prostředí může soudci velmi pomoci.

Chybějící odborné znalosti a prínos přísedících (nejen v pracovněprávních sporech) je českou veřejností mnohdy kritizován a vede $\mathrm{k}$ diskuzím o zrušení tohoto institutu. Záruku jistého stupně odbornosti př́sedících ve všech jmenovaných státech poskytují zástupci zaměstnanců a zaměstnavatelů, kteří se na výběru a nominaci príisedících podílejí. Podle vyjádření zaměstnaneckých organizací působících v České republice ale tento způsob výběru přísedících nepřipadá ani de lege ferenda $\mathrm{v}$ úvahu, a to $\mathrm{z}$ důvodů kapacitních. Je však nutné si uvědomit, že zástupci zaměstnanců a zaměstnavatelů by neměli na místa prísedících navrhovat pouze své členy, ale i jiné osoby, které by splňovaly podmínky, o kterých bylo výše pojednáváno. Je tedy otázkou, jestli se nejedná pouze o strach nebo obavy z prrevzetí zodpovědnosti za výběr a nominaci přísedících ze strany těchto subjektů.

Otázku odměňování př́sedících nechávám zcela stranou tohoto př́spěvku. Dovolím si toliko poukázat na vyhlášku ministerstva spravedlnosti České republiky č. 44/1992 Sb., o náhradách za vykonávání funkce př́sedícího, která platí v nezměněné podobě od 1. 1. 1996. Od roku 1996, kdy průměrná hrubá mzda činila 9.825 Kč/měsíčně, se odměny prísedících podle jmenované vyhlášky nezměnily, a to navzdory tomu, že průměrná hrubá mzda za 2 . čtvrtletí roku 2018 činila již $31.851 \mathrm{Kč} /$ měsíčně. ${ }^{27}$ Funkce prrísedícího je čestnou, ale zároveň veřejnou funkcí. Výše odměny by však neměla být jen symbolická, ale měla by i do jisté míry odrážet náročnost a důležitost výkonu funk-

\footnotetext{
26 Na jiném soudním jednání u odvolacího soudu jeden německý přísedící při rodícím se narovnání upozorňoval účastníky soudního řízení na to, že zkrácení pracovní doby zaměstnankyně, o kterém se v ten moment vedla diskuze, bude vyšší, než kterého se domáhala. Činil tak podle mého názoru s dobrým úmyslem, aby zaměstnavatel nebyl posléze překvapen, že zaměstnankyně je méně v práci, než původně čekal, a aby nebyla překvapena i zaměstnankyně, že její mzda bude nižší, než původně čekala. Toto upozornění však mohlo vyústit v neuzavření dohody. Díky zkušenosti soudce však všichni jmenovaný výrok přísedícího přešli bez větší pozornosti a dohoda mezi zaměstnavatelem a zaměstnankyní nakonec byla ke spokojenosti všech uzavřena.

27 Tato data jsou dostupná online na: <www.czso.cz> [cit. 17. 11. 2018].
} 
ce přísedícího. Blíže k této problematice viz Pichrt, Štefko a Morávek ${ }^{28}$ nebo Burgess a kol. ${ }^{29}$

\section{PŘÍSTUP K SOUDŮM}

Otázka přístupu $\mathrm{k}$ soudům je často diskutovaným tématem u těch skupin obyvatelstva, které nejsou dostatečně materiálně zajištěné. Zahájení civilního soudního řízení spolu nese zpravidla 3 typy nákladů, které musí každý žalobce/navrhovatel zvážit před tím, než samotné soudní rízení zahájí. Jedná se o náklady (1) na vlastní zastoupení, (2) na soudní poplatek a (3) na náhradu nákladů ř́zení protistraně, pokud žalobce/ navrhovatel nebude $\mathrm{v}$ ř́zení úspěšný. ${ }^{30}$

Česká právní úprava nezná $\mathrm{v}$ tomto ohledu téměř žádná specifika. Zmínit tak lze toliko osvobození od soudního poplatku navrhovatele $\mathrm{v}$ ř́zení o náhradu škody z pracovního nebo služebního úrazu a nemoci z povolání [viz § 11 odst. 2 písm. e) zákona č. 549/1991 Sb., o soudních poplatcích] a neexistenci povinnosti navrhovatele složit jistotu k zajištění náhrady škody nebo jiné újmy u předběžných opatření v pracovních věcech [viz $\S 75$ b odst. 3 písm. b) zákona č. 99/1963 Sb., občanský soudní řád]. V převládající soudní agendě, která je $\mathrm{v}$ pracovním právu tvořena spory o neplatnost skončení pracovněprávních vztahů a spory týkající se odměňování a jiných finančních vztahů, se tyto dvě výjimky nepoužijí. ${ }^{31}$ Zahraniční právní úprava a celkově i tamní nastavení společnosti jsou v tomto ohledu mnohem př́iznivější, což tamním zaměstnancům umožňuje účinně chránit jejich práva. Samotné zakotvení hmotněprávních oprávnění zaměstnanců totiž není bez adekvátních procesních pravidel účinné.

V Rakouské republice mají nepřehlédnutelné postavení komory pracovníků (tzv. Arbeiterkammern). Tyto komory jsou legislativně upraveny v zákoně o komorách pracovníků z roku $1992^{32}$ (dále též jako „AKG“), který jim ve svém úvodním ustanovení $\S 1$ - stanovuje úlohu spočívající v zastupování a podpoře sociálních, hospodářských, zaměstnaneckých a kulturních zájmů zaměstnanců a zaměstnankyň. Rakouský pojem zaměstnance je pro účely jmenovaného zákona širší než česká definice zaměstnance. Proto bude na tomto místě odkázáno na $\S 10$ odst. 1 a 2 AKG a odbornou literaturu ${ }^{33}$, která se pojmu zaměstnance tak, jak je chápán v Rakouské republice, věnuje.

28 PICHRT, J. - ŠTEFKO, M. - MORÁVEK, J. Analýzy alternativnich způsobů řešení sporů v pracovněprávních vztazích. S. 195 a 196.

29 BUGERSS, P., et al. The roles, resources and competencies of employee lay judges. A cross-national study of Germany, France and Geat Britain. S. 32 a 33.

30 Uvažována zde bude typická situace, kdy si žalobce/navrhovatel zvolí zástupce z řad advokátů, bude nutné zaplatit soudní poplatek a žalovaný/odpůrce bude rovněž zastoupen zástupcem z řad advokátů.

31 Srov. přehled o pravomocných rozhodnutích soudů v občanskoprávních věcech podle druhu sporů za rok 2016, který je dostupný online na: <cslav.justice.cz> [cit. 17. 11. 2018]. Za citovaný rok se jednalo o 2.464 pravomocně rozhodnutých sporů z celkových 3.745 .

$32 \mathrm{~V}$ originále se jedná o Arbeiterkammersgesetz, který je dostupný online na: <www.ris.bka.gv.at> [cit. 17. 11. 2018].

33 MARHOLD, F. - FRIEDRICH, M. Österreichisches Arbeitsrecht. 3. Auflage. Wien: Verlag Österreich, 2016, 782 s. ISBN 978-3-70466494-5. S. 46 a následující. 
Členství v komorách pracovníků je povinné a jejich členové jsou povinni platit př́spěvky ${ }^{34}$ na chod těchto organizací (s výjimkami uvedenými v $§ 17$ odst. 2 AKG). Výši př́spěvků stanovuje valná hromada Spolkové komory pracovníků; ta je však při svém rozhodování omezena zákonnými limity (blíže viz § 61 odst. 2 AKG).

Pro účely tohoto článku je však nejdůležitější § 7 odst. 1 AKG, který komorám pracovníků ukládá radit jejich členům v pracovněprávních a sociálněprávních záležitostech a obzvláště jim poskytovat právní ochranu prostřednictvím zastupování u soudu v pracovněprávních a sociálněprávních záležitostech. Díky existenci komor pracovníků, které svým členům poskytují právní zastoupení před soudy, si tak jejich členové nemusí hledat zástupce z řad advokátů, kterým by museli platit honoráře přesahující 100 Euro/ hodinu. Povinné členství je však trnem v oku některým politickým subjektům, a proto se o něm nezř́íka kdy diskutuje. ${ }^{35}$

Ve Spolkové republice Německo lze zmínit rozšiřrenost pojištění právní ochrany, které do jisté míry supluje komory pracovníků známé z Rakouské republiky. V roce 2017 dosahoval počet uzavřených smluv, jejichž předmětem bylo pojištění právní ochrany, hodnoty 22 milionů. Pro úplnost lze poznamenat, že uzavření pojištění právní ochrany není ve Spolkové republice Německo uloženo žádným předpisem. Tamní společnost jej však považuje za důležitý způsob ochrany před potenciálními riziky, která mohou vyplynout $\mathrm{z}$ běžného života člověka.

Po obstarání zástupce, který př́slušný př́ípad z oblasti pracovního práva posoudí, je nutné podat žalobu/návrh na soud. S tím je spojená poplatková povinnost. Jedná se tedy v pořadí o druhý náklad, který je žalobce/navrhovatel nucen vynaložit, aby se mohl domoci svého nároku. Splatnost soudních poplatků v pracovněprávních věcech ve Spolkové republice Německo však nenastává již podáním žaloby/návrhu na soud, ale často až jejím vyř́zením (viz $§ 6$ odst. 3 ve spojení s $§ 9$ odst. 2 zákona o soudních poplatcích z roku $2004^{36}$ - dále též jako „GKG“). V Rakouské republice jsou pracovněprávní spory s hodnotou do 2.500 Euro dokonce osvobozeny od poplatků. ${ }^{37}$ Ve Spolkové republice Německo pak v př́ípadě uzavření smíru může dojít k odpadnutí poplatkové povinnosti. ${ }^{38}$ Jmenované instituty tak podstatným způsobem usnadňují zahájení soudního řízení v pracovněprávních věcech.

V neposlední řadě musí každý žalobce/navrhovatel zvážit, co může $\mathrm{v}$ př́ípadě neúspěchu jeho žaloby/návrhu ztratit. S výjimkou toho, že se před soudem nedomůže toho, o co usiloval, musí v civilním procesu očekávat, že ponese náklady, které vynaložil žalovaný/odpůrce, tedy jeho protivník. V pracovních věcech toto v Rakouské republice ani ve Spolkové republice Německo neplatí.

34 Průměrná měsíční výše př́spěvku činí 6,91 Euro, maximální výše příspěvku je omezena částkou ve výši 14,41 Euro, viz <www.arbeiterkammer.at> [cit. 17. 11. 2018].

35 Viz např. zpráva s názvem Heftige Debatte über AK-Beiträge und Kammer-Pflichtmitgliedschaft, která pochází z dubna roku 2015 a je dostupná online na: <www.parlament.gv.at $>$ [cit. 17. 11.2018].

$36 \mathrm{~V}$ originále se jedná o Gerichtskostengesetz, který je dostupný online na: <www.gesetze-im-internet.de> [cit. 17. 11.2018].

37 Viz poznámka č. 8 zákona o soudních poplatcích z roku 1997; v originále se jedná o Gerichtsgebührengesetz (dále též jako „GGG“), který je dostupný online na: <www.ris.bka.gv.at> [cit. 17. 11. 2018].

38 Viz část 8 GKG. 
Ve Spolkové republice Německo je právní úprava $\mathrm{v}$ tomto ohledu přehlednější. $\mathrm{V} \S 12 \mathrm{a}$ odst. 1 větě první ArbGG je stanoveno, že v rozsudkových řízeních ${ }^{39}$ prvního stupně nemá vítězná strana nárok na náhradu nákladů spočívajících v přibrání procesního zmocněnce nebo podpůrce/pomocníka. Rakouská právní úprava je v tomto ohledu velkorysejší, když nárok na náhradu nákladů připouští až v řízení u Nejvyššího soudního dvora (der Oberste Gerichtshof), který je nejvyšším soudem v rámci tamní soustavy obecných soudi̊. ${ }^{40}$

\section{ZÁVĚR}

Pracovněprávní soudnictví může vykazovat mnohá specifika. Česká právní úprava je ve srovnání s vyspělými státy západní Evropy téměř pravým opakem, protože $\mathrm{s}$ výjimkou př́sedících, kteř́ byli diskutováni v první polovině tohoto př́spěvku, nezná v podstatě žádný jiný právní institut, který by podstatnějším způsobem ovlivňoval pracovněprávní proces.

Za nestandardní lze označit, že čeští přísedící v pracovněprávních věcech nejsou vybíráni ani nominováni zástupci zaměstnanců a zaměstnavatelů, jak je tomu běžně zvykem. Stejně tak není zvykem, aby při výběru kandidátů na př́ísedící nehrála významnější roli ani jejich odborná znalost pracovního prostředí.

Ve druhé části této stati bylo hovořeno o př́istupu $\mathrm{k}$ soudům $\mathrm{v}$ pracovněprávních věcech. $\mathrm{V}$ tomto ohledu je česká právní úprava zcela nepoznamenaná. Inspiraci by bylo možné hledat ve Spolkové republice Německo nebo v Rakouské republice, a to např. formou snížení soudních poplatků v pracovněprávních věcech nebo zrušením náhrady nákladů řízení alespoň před soudem prvního stupně. Současný stav v této oblasti pak podle mého názoru odrazuje zejména hưr̆e situované zaměstnance, kteří by se rádi domáhali svých nároků podáním žaloby/návrhu, protože náklady v prípadě neúspěchu by pro ně byly neúnosné.

V roce 2016 bylo ve Spolkové republice Německo podáno více než 360 tisíc žalob/ návrhů $\mathrm{v}$ pracovněprávních věcech a téměř totožný počet jich byl vyř́zen. ${ }^{41}$ Ve Spojeném Království Velké Británie a Severního Irska bylo podáno za období finančního roku 2016/2017 přes 88 tisíc žalob/návrhů. ${ }^{42}$ V roce 2016 pak bylo v České republice vyřízeno přes 3,7 tis. žalob/návrhů v pracovních věcech; je možné předpokládat, že počet vyř́zzených věcí za toto období mohl být obdobný ${ }^{43}$. Na základě těchto údajů si

39 Jedná se o řízení uvedená $\mathrm{v} \S 12$ ArbGG, pod který by se dala zjednodušeně řečeno zařadit všechna řízení vyplývající z individuálního pracovního práva.

40 Okruh př́padů, na které tato právní úprava dopadá a na které odkazuje § 58 odst. 1 věta první ASGG, je uveden v $\$ 50$ odst. 2 ASGG, který odkazuje na část II., V., VI., VII. a VIII. zákona o pracovních zřízeních z roku 1973; v originálně se jedná o Arbeitsverfassungsgesetz (dále též jako „ArbVG“), který je dostupný online na: <www.ris.bka.gv.at> [cit. 17. 11. 2018]; zmiňované části ArbVG obsahují např. úpravu skončení pracovního poměru.

41 Viz < www.bmas.de $>$ [cit. 25. 6. 2018].

$42 \mathrm{Viz}<$ www.gov.uk $>$ [cit. 17. 11. 2018].

43 Bohužel se mi nepodařilo dohledat přesná data k počtu zahájených soudních řízení v pracovněprávních věcech. Nedomnívám se však, že by se můj předpoklad o přibližně stejné výši nově zahájených věcí 
lze udělat přibližný názor na to, jaký je přístup $\mathrm{k}$ soudům v pracovněprávních věcech $v$ těchto třech jmenovaných státech. ${ }^{44}$

I s ohledem na uvedená data doufám, že do českého procesního práva budou v budoucnu zapracovány alespoň některé instituty, které znají za hranicemi a které by umožnily účinněji hájit práva zejména zaměstnanců, kteří jsou $v$ drtivé většině případů skutečně těmi slabšími v pracovněprávních vztazích, čímž si zvýšenou ochranu nejen v hmotném právu zaslouží. Jestli se tomu tak ale skutečně stane, je otázkou.

Ing. Mgr. Patrik Stonjek

Právnická fakulta Univerzity Karlovy

stonjek.patrik@seznam.cz

a o počtu vyřízených starších případů zásadně odchyloval od reality. Průměr vyřízených pracovních věcí za roky 2010-2017 činil přibližně 4,6 tis. žalob/návrhů.

44 Spojené království Velké Británie a Severního Irska jsem vybral z toho důvodu, že se jedná o nejméně sociálně orientovaný stát ze všech, které byly v tomto příspěvku zmíněny, a to navzdory tomu, že o něm nebylo podrobněji hovořeno. Jedná se tedy o údaj sloužící pro ilustraci čtenáře, jaký je nápad pracovněprávních věcí v různých částech Evropy, které se liší svým sociálním, kulturním i právním prostředím. 



\title{
NÁZOR REJSTŘÍKOVÝCH SOUDU゚: ODBOROVÁ ORGANIZACE SPOLKEM, ČI RADĚJI NE?
}

\author{
MARTIN ŠTEFKO*
}

\begin{abstract}
Registrar's Opinion on Trade Union's Legal Status
This paper deals with registrar's standards procedure when they are required to register a trade union organisation into the Registry of Associations. There is an ongoing discussion on trade union's legal status among scholars, practitioners and even judges. Some claim they are associations, but they are opposed by trade union's establishment and few registrars. If this happens those trade unions are denied the entry to the register, what has been meanwhile overruled by upper courts, or they are required to change their name deleting the term "association" thereof.
\end{abstract}

Keywords: Trade Union; Association; Registry of Associations; Registrar Court

Klíčová slova: odborová organizace; spolek; spolkový rejstř́k; rejstř́ikový soud

DOI: $10.14712 / 23366478.2019 .11$

\section{ÚVOD}

České kolektivní pracovní právo bylo nuceno se při rekodifikaci soukromého práva dokončené v roce 2014 vypořádat s pojmovým uchopením odborové organizace jako konkrétního typu právnické osoby. Názory byly různé a diskuze poměrně bouřlivé. S jistým odstupem se do řešení tohoto problému zapojila též judikatura, a to včetně nejvyšších článkủ soudní soustavy. Př́nos judikatury byl a je rozhodující, bohužel praxe rejstř́ikových soudů zatím zcela jednotná není. Některé odborové organizace mají v názvu zmíněno, že jsou spolkem, jiné nikoliv. Dle stavu zápisu ve spolkovém rejstř́íku spíše převažují ty odborové organizace, které se jako spolek v názvu neidentifikují.

Cílem tohoto článku je poukázat na pozadí různých názorových proudů a za využití detailního výzkumu stavu zápisů ve spolkovém rejstř́ku na teoretické i praktické pojmové uchopení odborové organizace jako základní figury pracovního práva. Za tím účelem bude proveden nejprve historický vhled do zkoumané problematiky, aby následně došlo $\mathrm{k}$ analýze právní úpravy, názorů doktríny a soudobé rejstř́íkové praxe.

\footnotetext{
* Autor působí jako docent na katedře pracovního práva a práva sociálního zabezpečení a je rovněž advokátem Kocián Šolc Balaštík, advokátní kancelář, s.r.o.
} 


\section{HISTORICKÝ EXKURZ}

Pojem odborové organizace byl vždy poněkud nejasný. ${ }^{1}$ Souvisí to jednak s jeho živelným vývojem v 19. století, jednak se státní represí, k jejímuž postupnému uvolnění dochází v českých zemích teprve po roce $1867 .^{2}$ Identifikující pro tato společenstva byl především materiální prvek, řečeno dnešní pracovněprávní terminologií: sdružování za účelem vzájemného posílení sociální bezpečnosti. Jedná se v podstatě o starou myšlenku dělnické participace na ř́zení podniku, která byla v 19. století zastávána ovšem pouze několika socialistickými filozofy a sociálně demokratickým hnutím. ${ }^{3} \mathrm{~K}$ její realizaci došlo poprvé ve Velké Británii u obecních podniků a v Rusku (zákon č. 23. 4. 1917). Po první světové válce jisté formy zaměstnanecké participace legislativně podchytilo též Rakousko, ČSR a Německo. V té nejširší podobě, jak ji známe dnes, tedy jako povinné personální informace a konzultace, kolektivní vyjednávání, zaměstnanecké rady, spolurozhodování v podnikových radách, účast v řídících orgánech podniku a samořízení, však byla upravena teprve po druhé světové válce, a to takřka výlučně veřejnoprávními předpisy.

Odborová organizace tedy vždy ze své podstaty bojovala a bojuje za ochranu a zlepšení pracovních podmínek zaměstnanců. Je tak význačným prvkem demokratizmu v pracovním právu, jakož i projevem zaměstnanecké a lidské solidarity. Za odborové organizace se v souladu s např. čl. 10 Úmluvy Mezinárodní organizace práce č. $87^{4}$ považovaly takové organizace, které měly za cíl podporovat a hájit zájmy zaměstnanců, a jejich cílem bylo a je vytváření podmínek pro uplatňování pracovních, ekonomických, mzdových, sociálních a kulturních zájmů svých členů, zastupování členů při jednáních se zaměstnavatelem, spolurozhodování o tvorbě a rozdělování finančních prostředků a vedení kolektivního vyjednávání se zaměstnavatelem.

Představené materiální pojetí je ovšem vysoce subjektivní, a proto obtížně prokazatelné. Pro zaměstnavatele jako sociálního partnera i členy předmětné odborové organizace je často velmi obtížně seznatelné, zda určité konkrétní kroky odborové organizace jsou opravdu v zájmu zaměstnanců. Státní orgány tomuto faktu čelily v různých dobách různě. Zmínit lze např. kroky nacistické okupační moci, která centralizovala zástupce zaměstnanců do Národní odborové ústředny zaměstnanecké (NOÚZ), ${ }^{5}$ kterou pak následně využívala $\mathrm{k}$ propagandistickým účelům. $\mathrm{V}$ této souvislosti lze zmínit ust. $§ 1$ vládního nařízení o úpravě poměrů v odborových organizacích zaměstnaneckých ze dne 14. srpna 1941, č. 347 Sb., dle kterého o tom, zda je zaměstnanecká organizace organizací odborovou, rozhodoval úr̆ad dle své úvahy.

1 K platnému vymezení odborové organizace především J. Pichrt v komentári $\mathrm{k}$ ust. § 286. In: BĚLINA DRÁPAL a kol. Zákoník práce, komentáŕ. 2. vyd. Praha: C. H. Beck, 2014, s. 1112.

2 Viz např. MALÝ, K. Policejní a soudní perzekuce dèlnické třídy v druhé polovině 19. stoleti v Čechách. 1. vyd. Praha: Academia, 1967. 282 s.

3 TOMEŠ, I. Zaměstnanecká participace na ř́zení podniku. Právník. 1991, č. 5, s. 369.

4 Úmluva o svobodě sdružování a ochraně práva odborově se organizovat (sdělení federálního ministerstva zahraničních věcí č. 489/1990 Sb.)

5 K tomu zejména PICHRT, J. In: BĚLINA, M. a kol. Pracovní právo. 6. vydání. Praha: C. H. Beck, 2014, s. 146. 
Tento materiální znak byl akceptován též judikaturou. ${ }^{6}$ Nutno ovšem dodat, že ochranou a hájením zájmů zaměstnancủ byly pověřeny v minulosti též jiné orgány ${ }^{7}$ a že jednoznačné vítězství odborové organizace $\mathrm{v}$ tomto směru jako univerzálního zástupce zaměstnanců nebylo ani zdaleka spontánní. ${ }^{8}$

Pokud jde o úpravu formálního znaku odborové organizace v recentní historii, tedy její právní osobnosti, pak lze především poukázat na ust. § 1 zákona č. 144/1946 Sb., o jednotné odborové organizaci, jež na dlouho spojilo odborové organizace zř́zené ve formě spolku s názvem Revolučním odborovým hnutím. ${ }^{9}$

Právní úprava odborové organizace pokročila do nové fáze zákonem č. 68/1951 Sb., o dobrovolných organizacích a shromážděních. ${ }^{10}$ Předmětný zákon byl založen na povolovacím principu, což samožrejmě neuniklo pozornosti Mezinárodní organizace práce. Vzhledem k jejím námitkám, že zákon č. 68/1951 není v souladu s Úmluvou o odborové svobodě a ochraně odborového práva z r. 1948, byl tento změněn zákonem č. 74/1973 Sb. s účinností od 3. července 1973 tak, že ustanovení $§ 1$ až 5 ,se nevztahují na odborové organizace“.11

Předposlední vývojovou fází byla úprava v usnesení IV. všeodborového sjezdu o závodních výborech základních organizací Revolučního odborového hnutí, které bylo publikováno jako př́loha zákona č. 37/1959 Sb. o postavení závodních výborů základních organizací Revolučního odborového hnutí. ${ }^{12}$ Dle bodu 24 usnesení IV. všeodborového sjezdu o závodních výborech základních organizací Revolučního odborového hnutí (ROH) byl závodní výbor prohlášen prostě za právnickou osobu. ${ }^{13}$ Ústřední rada odborů mohla dále prohlásit za právnické osoby i jiné odborové orgány či účelová zaří-

6 Usnesení Krajského soudu Praha č. j. 30 Co 116/2003-06-16 in: Bulletin Advokacie. 2003, č. 10, s. 60. Dále např. rozsudek Nejvyššího soudu ze dne 28. května 2013, sp. zn. 21 Cdo 390/2012.

7 K tomu např. zákon z 25. února 1920, č. 144 Sb. z. a n., o závodních a revírních radách při hornictví, zákon ze dne 12. srpna 1921, č. 330 Sb., o závodních výborech nebo Dekret prezidenta republiky č. 104/1945 Sb. o závodních a podnikových radách.

8 Spolu s nástupem detailního direktivního řízení dochází postupně k umlčování závodních a podnikových rad a k jejich nahrazování jednotnou odborovou organizací. Formálně se tak stalo zákonem č. 37/1959 Sb., o postavení závodních výborů základních organizací Revolučního odborového hnutí, který zrušil dekret prezidenta republiky č. 104/1945 Sb., o závodních a podnikových radách. K tomu např. KALENSKÁ, M. Pracovni právo v tržním hospodářství, s. 705. Dále PICHRT, J. In: BĚLINA, M. a kol. Pracovní právo. 6. vyd. Praha: C. H. Beck, 2014, s. 354.

9 Zákon č. 144/1946 Sb., o jednotné odborové organizaci posléze našel posléze svoji oporu v Ústavě 9 . května. K tomu srov. ust. $\S 25$. Ústř̌ední rada odborů byla nicméně pověřena k převzetí všech odborových svazů a spolků v českých zemích již 6. května 1945 Českou národní radou. Výnos Ministerstva vnitra č. IV-311119/5-45 ze dne 19. května 1945 pak označil ÚRO za právního nástupce všech odborových organizací.

10 Zde se jednak ,jednotná odborová organizace“ uvádí jako př́klad dobrovolné organizace (v ust. § 1), jednak se Revoluční odborové hnutí prohlašuje za organizaci podle tohoto zákona (ust. § 5). Zákon č. 68/1951 Sb. upravil dobrovolné organizace jako formu dobrovolného sdružování s posláním směřujícím především $\mathrm{k}$ upevnění lidově demokratického zřízení a $\mathrm{k}$ podpoře úsilí o výstavbu socialismu. $\mathrm{V}$ důsledku této kvalitativní změny v právní úpravě dobrovolného sdružování bylo těžiště sdružování z oblasti spolků přeneseno do většinou celostátních masových „dobrovolných“ organizací. Tak na jedné straně rostl počet dobrovolných organizací podle zákona č. 68/1951 Sb., na druhé straně pronikavě poklesl počet spolků.

11 Srov. čl. I zákon č. 74/1973. Sb.

12 PICHRT, J. In: BĚLINA, M. a kol. Pracovní právo. 6. vyd. Praha: C. H. Beck, 2014, s. 354.

13 Judikatura označení právnická osoba specifikovala na právnickou osobu socialistického charakteru, která je současně socialistickou organizací. K tomu rozhodnutí Nejvyššího soudu ze dne 31. 10. 1962, sp. zn. 6 Cz 29/62. 
zení ROH. ${ }^{14}$ Dle bodu 18 předmětného usnesení současně platilo, že stanovy odborové organizace a opatření podle nich učiněná nepodléhají schválení ani evidenci státních orgánů. K zajištění jednotného výkladu a provádění byla autorizována Ústřední rada odborů, aby vydala potřebné směrnice. ${ }^{15}$

Zákon č. 37/1959 Sb. byl zrušen čl. III bodem 1 zákona č. 3/1991 Sb., kterým se mění a doplňuje zákoník práce s účinností k 1. 2. 1991. Novou komplexní úpravu přinesl od 1. 5. 1990 zákon č. 83/1990 Sb., o sdružování občanů. Důvody jeho přijetí jsou pregnantně vymezeny $\mathrm{v}$ důvodové zprávě. Od přijetí výše zmíněného zákona č. 74/1973 Sb. nebyly vznik, působení a zánik odborových organizací nijak právně upraveny, což však vzhledem k tehdejším mocenským poměrům nevadilo, nebot' stejně nové odborové organizace vznikat nemohly. ${ }^{16}$ Proto bylo namístě výslovně v ust. § 2 zákona o sdružování občanů dovolit zakládat odborové organizace. Protože registrace měla být pouze deklaratorním rozhodnutím (správní orgán měl pouze zjišt’ovat, zda sdružení splňuje předpoklady stanovené zákonem), měl se tento režim aplikovat též na vznik odborových organizací. Zákonodárce nicméně nakonec od této úpravy ustoupil a pro vznik odborové organizace raději zásadní výjimky upravil zákonem č. 300/1990 Sb. Ten s účinností k 19. 7. 1990 přinesl zvláštní úpravu v ust. § 9a založenou na evidenčním principu. Tato úprava pak s jedinou dílčí změnou ${ }^{17}$ vydržela až do svého zrušení občanským zákoníkem. ${ }^{18}$

\section{POJMOVÉ ZAŘAZENÍ ZÁKLADNÍ ODBOROVÉ ORGANIZACE V PLATNÉ ÚPRAVĚ}

Občanský zákoník v části páté hlavě druhé příznačně nazvané „Ustanovení přechodná a závěrečná“ obsahuje v ust. § 3046 obč. zák. pravidlo, které je nutno aplikovat beze zbytku, nikoliv pouze přiměřeně. Dle předmětného ustanovení platí, že odborová organizace a jejich organizační jednotky evidované podle zákona č. 83/1990 Sb., o sdružování občanů, ve znění pozdějších předpisů se považují za odborové organizace a jejich pobočné organizace podle občanského zákoníku. Z ust. § 3041 odst. 1 první věty obč. zák. pak vyplývá, že právní povaha právnických osob upravených občanským zákoníkem se řídí ustanoveními občanského zákoníku od dne 1. 1. 2014. Ve shodě s tímto někteří autoři skutečně považují odborové organizace ve smyslu terminologie občanského zákoníku za spolky. ${ }^{19}$

14 Toto oprávnění vyplývalo dle judikatury již z ust. § 2 bod 2 zákona č. 144/1946 Sb. K tomu viz rozhodnutí krajského soudu v Ostravě z 12. ř́ijna 1952, sp. zn. 10 Ok 199/52.

15 Usnesení IV. všeodborového sjezdu o závodních výborech základních organizací.

16 Tisk 281, FS ČSSR, V. volební období, 1990, čl. I, tisk je dostupný online na: <http://www.psp.cz/eknih /1986fs/tisky/t0281_00.htm> [cit. 15.2.2015].

17 Provedenou zákonem č. 227/2009 Sb.

18 Zákon č. 65/1965 zákoník práce ji zachoval v ust. § 279 odst. 4. Dle předmětného ustanovení se zákon č. 37/1959 Sb. spolu s usnesením připojuje jako př́loha k zákoníku práce. Ústava ČSSR v čl. 5 uváděla Revoluční odborové hnutí jako př́klad dobrovolných společenských organizací.

19 K platnému vymezení odborové organizace především J. Pichrt v komentáři k ust. § 286 in: BĚLINA, M. - DRÁPAL, L. a kol. Zákoník práce, komentár̆. 2. vyd. Praha: C. H. Beck, 2014, s. 1112. 
Protože Česká republika ctí své mezinárodní závazky, zejména úmluvy Mezinárodní organizace práce, bylo do občanského zákoníku zařazeno ust. § 3025, z něhož vyplývá, že ustanovení občanského zákoníku o právnických osobách a spolku se použijí na odborové organizace přiměřeně jen $v$ tom rozsahu, $v$ jakém to neodporuje jejich povaze zástupců zaměstnanců podle mezinárodních smluv, kterými je Česká republika vázána a které upravují svobodu sdružování a ochranu práva svobodně se sdružovat. Odborové organizace jsou tedy ust. § 3025 obč. zák. klasifikovány jako právnická osoba-spolek, $\mathrm{s}$ účelově volnějším režimem. ${ }^{20}$ Takto výslovně to stanoví též konsolidovaná důvodová zpráva. ${ }^{21}$ Jako důvod speciálního režimu je v důvodové zprávě uváděna výslovně Úmluva MOP č. 87 o svobodě sdružování a ochraně práva odborově se organizovat, 1948 (č. 489/1990 Sb.). ${ }^{22}$

Občanský zákoník sám používá v ust. § 3046 označení odborová organizace; stejně tak ust. § 26 odst. 1 písm. b) zákona č. 304/2013 Sb., o veřejných rejstřících právnických a fyzických osob, v platném znění rovněž uvádí pojem odborové organizace a zkracuje jej jako spolek. V ust. § 121 zákon č. 304/2013 Sb. se ovšem opět používá pojem odborová organizace.

Odborná literatura po 1. 1. 2014 při označení základní odborové organizace tenduje k označení spolek, ${ }^{23}$ někdy též spolek sui generis. ${ }^{24}$ Další autoři toto označení zcela odmítají a trvají na svébytném pojmu odborová organizace. ${ }^{25}$ Metodika Českomoravské konfederace odborových svazů, kterou můžeme vzít jako př́klad názoru odborových organizací, výslovně pojmovou klasifikaci odborových organizací neprovádí, ${ }^{26}$ na druhou stranu tato odborová centrála svi̊j názor opakovaně jednoznačně vyjádřila v tomto i v ji-

20 Srov. K tomu konsolidovaná důvodová zpráva k NOZ, s. 589, z literatury pak např. VÁCHA, J. Odborové organizace v područí právní úpravy v novém občanském zákoníku. Pracovní právo. 2013, s. 2 dostupné též na: <https://www.law.muni.cz/sborniky/pracpravo2013/files/010.html> [cit. 13. 2. 2016]; dále komentár T. Dvořáka in: ŠVESTKA, J. - DVOŘÁK, J. - FIALA, J. a kol. Občanský zákoník. Komentář. Svazek VI. Praha: Wolters Kluwer, 2014, s. 1332.

21 Konsolidovaná důvodová zpráva k NOZ, s. 589.

22 Konsolidovaná důvodová zpráva k NOZ, s. 589.

23 RONOVSKÁ, K. In: LAVICKÝ, P. a kol. Občanský zákoník I. Obecná část (\$ 1-654). Komentář. 1. vydání, Praha: C. H. Beck, 2014, s. 2307. Dále KOSTADINOVOVÁ, I. Odborová organizace jakožto občanské sdružení alias spolek po rekodifikaci soukromého práva v České republice, dostupný online na: <http:// www.law.muni.cz/sborniky/pracpravo2013/files/011.html > [cit. 15. 5. 2016].

24 Srov. komentář T. Dvořáka in: ŠVESTKA, J., DVOŘÁK, J., FIALA, J. a kol., Občanský zákoník. Komentár̆. Svazek VI. Praha: Wolters Kluwer, 2014, s. 1383, dále VÁCHA, J. Odborové organizace v područí právní úpravy v novém občanském zákoníku. Pracovní právo. 2013, s. 2 dostupné též na: <https://www .law.muni.cz/sborniky/pracpravo2013/files/010.html> [cit. 13. 9. 2016].

25 STRÁNSKÝ, J. - SAMEK, V. - HORECKÝ, J. Nový občanský zákoník a pracovní právo. Praha: Sondy, 2014, s. 67. Srov. však další argumenty J. Pichrta v komentáři k ust. § 286. In: BĚLINA, M. - DRÁPAL, L. a kol. Zákoník práce, komentár̆. 2. vyd. Praha: C. H. Beck, 2014, s. 1113.

$26 \mathrm{~K}$ tomu s. 4 dokumentu dostupného online na: $<$ http://www.google.cz/url?sa=t\&rct=j\&q=\&esrc=s\&source =web \&cd=1\&ved=0CCIQFjAA\&url=http $\% 3$ A \%2F\%2Fvos.cmkos.cz\%2Ffile_download \%2F $1213971989 \% 2$ FMetodika\%2B\%25C4\%258CMKOS $\% 2 B k \% 2 B$ nov $\% 25 \mathrm{C} 3 \% 25 \mathrm{~A} 9 \% 2 \mathrm{~B}$ $\% 25 \mathrm{C} 3 \% 25 \mathrm{BAprav} \% 25 \mathrm{C} 4 \% 259 \mathrm{~B} \% 2 \mathrm{Bpostaven} \% 25 \mathrm{C} 3 \% 25 \mathrm{AD} \% 2 \mathrm{C} \% 2 \mathrm{Bpr} \% 25 \mathrm{C} 3 \% 25 \mathrm{~A} 1 \mathrm{v}$ $\% 2 \mathrm{Ba} \% 2$ Bpovinnost $\% 25 \mathrm{C} 3 \% 25 \mathrm{AD} \% 2 \mathrm{Bodbo}$. doc\&ei=3WHaVNmBPILxUuenhLAO\&usg=AFQjCNF -2AnD6_HrKrt4u4LXwUg6fVnjXA\&bvm=bv.85464276,d.d24> [cit. 10. 2. 2016]. 
ných dokumentech tak, že se jedná o „,právnickou osobu sui generis“. ${ }^{27}$ Dle ČMKOS se ust. § 216 občanského zákoníku na odborové organizace nevztahuje. ${ }^{28}$

Některé svazy se raději ve svých vyjádřeních drží též s odkazem na čl. 20 odst. 1 Listiny základních práv a svobod již zažitého pojmu občanské sdružení. ${ }^{29}$ Návrh zákona o evidenci odborových organizací, pobočných odborových organizací, organizací zaměstnavatelů a pobočných organizací zaměstnavatelů a o změně některých dalších zákonů (zákon o evidenci organizací) ve znění, v jakém byl předložen k projednání Legislativní radě vlády se s ohledem na obecné soukromé právo přidržel označení pobočná odborová organizace a hlavní organizace.

\section{1 ÚMLUVA MOP Č. 87}

Výklad relevantní úmluvy č. 87 ze strany Mezinárodní organizace práce, vyplývá z dokumentu označeného Freedom of Association, Digest of decisions and principles of the Freedom of Association Committee of the Governing Body of the ILO, Fifth (revised) edition (dále ,Digest" ${ }^{6}{ }^{30}$ Relevantní je v této souvislosti zejména část šestá Digest nazvaná „Right of organizations to draw up their constitutions and rules“. Ze závěrů obsažených v této části lze dovodit, že přijetí zákonné úpravy regulující fungování odborové organizace není samo o sobě v rozporu s mezinárodně garantovanou autonomií odborových organizací tvořit vlastní stanovy a pravidla fungování (závěr 370 Digest), pokud je tato úprava obecná. Rozhodování rejstř́k kového soudu při zápisu práv a povinností odborové organizace by tvořily problém pouze tehdy, pokud toto rozhodování bylo mimo diskreční pravomoc tohoto soudního orgánu (závěr 373 Digest).

Podrobná regulace vnitřního fungování odborové organizace je však považovaná za problematickou (závěr 369 Digest), pokud by se nejednalo o toliko formální (minimální) požadavky na podobu tohoto vnitřního fungování (závěr 371 Digest). Regulace vztahů odborových svazů a základních organizací by měla být výjimečná a jako taková použitelná pouze pro neobvyklé př́ípady (závěr 386 Digest). Odborové organizace by navíc $\mathrm{v}$ těchto případech měly mít zachovány všechny možné nástroje obrany proti zásahům do jejich autonomie (závěr 386 Digest).

27 Např. v dokumentu nazvaném Požadavky ČMKOS na změny v oblasti nového soukromého práva (Podklad pro jednání RHSD) ze dne 14. 3. 2014. Dokument je dostupný online na: <http://www.google.cz/ url? sa=t\&rct=j\&q=\&esrc=s\&source=web\&cd=31\&ved=0CB8QFjAAOB4\&url=http\%3A\%2F\%2Fkzps. cz\%2Fwp-content $\% 2$ Fuploads\%2F2014\%2F09\%2Fk-bodu-2-2-pozadavky-cmkos-na-zmeny-v-oblasti-noveho-soukromeho-prava-podklad-pro-rhsd.doc\&ei=73fiVP2aBav-ygOax4Fw\&usg=AFQjCNE9sjTv39BmbLWO11wAcmaLYqCGwQ\&sig2=TMx77tSzcqipQqC0sUt_xQ> [cit. 6. 10. 2016].

28 Ust. § 216 občanského zákoníku zní: „Název spolku musí obsahovat slova „spolek“ nebo ,zapsaný spolek“, postačí však zkratka ,z. s.“"

29 Za všechny např. názor Odborového svazu pracovníků hornictví, geologie a naftového průmyslu <http:// www.google.cz/url? sa=t\&rct=j\&q=\&esrc=s\&source=web\&cd=6\&ved=0CEEQFjAF\&url=http $\% 3 \mathrm{~A} \%$ 2 F\%2Fwww.osphgn.cz\%2Ffile $\% 2$ F 74\%2Fodborova-organizace-v-nove-uprave-soukromeho-prava-a-verejnem-rejstriku-pravnickych-a-fyzickych-osob.doc\&ei=TF_iVPfXLcGBUdSFgtAJ\&usg=AFQjCNEHjB211jd7LSA2MMWjZElsHOc-Ww\&sig2=xVlw2cfNmByqMGM4GW48Qw\&bvm=bv.85970519,d. d24> [cit. 19. 8. 2016].

30 Publikace je dostupná online na: <http://www.ilo.org/wcmsp5/groups/public/---ed_norm/---normes/documents/publication/wcms_090632.pdf $>$ [cit. 11.2.2015]. 


\section{REJSTŘÍKOVÉ SOUDY}

V souvislosti s rejstř́íkovým řízením již sociální partneři učinili poznatky svědčící dle jejich názoru o problematičnosti platné úpravy i její aplikace rejstř́kovými soudy. ${ }^{31}$ Jejich názor podpořilo též Ministerstvo práce a sociálních věcíí ${ }^{32}$ a opakovaný tlak nakonec vyústil v rozhodnutí vlády ze dne 3. listopadu 2014, která usnesením č. 892 uložila ministryni práce a sociálních věcí zpracovat v součinnosti s ministryní spravedlnosti návrh zákona o evidenci odborových organizací a organizací zaměstnavatelů a předložit jej vládě do 31 . prosince $2014 .{ }^{33}$ Návrh zákona přes opakované snahy nakonec schválen nebyl. ${ }^{34}$

I do rejstř́íkového řízení se tak přenesl teoretický problém, zda odborová organizace je či není spolkem. Většina rejstř́kových soudů tuto otázku ponechala na odborové organizaci a respektovala názor navrhovatele. Dle stavu spolkového rejstř́ku lze identifikovat desítky odborových organizací, jejichž názvy nevyhovují ust. § 216 občanského zákoníku a nepoužívají ve svém názvu slovo „spolek“ či identifikační zkratku této právní formy. Na druhou stranu existuje též řada odborových organizací, které se jako spolek výslovně ve svém názvu označují. ${ }^{35}$ Některé odborové organizace jsou dokonce př́mo ve spolkovém rejstř́ku zapsány z hlediska právní formy jako spolek, konkrétně jde např. o Odborový spolek zaměstnanců VOŠ a SŠ Varnsdorf, Karolíny Světlé $2703,{ }^{36}$ Odborový svaz SECURIOS, z. s. ${ }^{37}$ či z judikatury známější Odborová organizace Sluníčko. ${ }^{38}$

Krajský soud v Českých Budějovicích jako zatím jediný zaujal jednoznačný názor, že i když se odborová organizace zapisuje do spolkového rejstř́ku, není spolkem, a proto se jako spolek ani nesmí označovat. Dovolává se přitom ust. § 132 odst. 2 občanského zákoníku, dle kterého: „Název musí odlišit právnickou osobu od jiné osoby a obsahovat označení jeji právní formy. Název nesmi být klamavý. “Ani Krajský soud v Českých Bu-

31 Diskutováno např. na 110. plenárním zasedání schůze RHSD dne 30. června 2014.

32 Srov. materiál připravený Ministerstvem práce a sociálních věcí materiál „Řešení problémů evidence odborových organizací a organizací zaměstnavatelü“, který byl předložen na zasedání 111. Plenární schůze RHSD, konané 28. července. 2014. Dokument je dostupný na: <http://www.ospzv-aso.cz/addons/111\%20RHSD /Reseni-problemu-evidence-odborovych-organizaci-a-organizaci-zamestnavatelu.pdf $>$ [cit. 15. 2. 2018].

33 Meziresortní připomínkové řízení probíhalo ve dnech 27. listopadu až 12. prosince 2014. Bliže viz $<$ https:// apps.odok.cz/kpl-detail?pid=KORN9R9JDXGI > [cit. 15. 2. 2018].

34 Srov. <https://apps.odok.cz/attachment/-/down/IHOAA2PARRUZ> [cit. 7. 10. 2016].

35 Namátkově lze odkázat na spolky: Odborová organizace pracovníkủ Moravské filharmonie Olomouc z. s., vedená u Krajského soudu v Ostravě, sp. zn. L 16440, Odborová organizace zaměstnancủ Fondu dalšího vzdělávání z. s., vedená u Městského soudu v Praze, sp. zn. L 66006, ODBOROVÁ ORGANIZACE KASI z.s. vedená u Krajského soudu v Hradci Králové, sp. zn. L 9964, Odborová organizace JASNÁ CESTA, z.s. vedená u Krajského soudu v Ostravě, sp. zn. L 11330, Nezávislá odborová organizace Fehrer Bohemia, s.r.o. - závod 02, spolek, vedená u Krajského soudu v Ústí nad Labem, sp. zn. L 5777, Nezávislá odborová organizace Fehrer Bohemia, s.r.o. - závod 01, spolek, vedená u Krajského soudu v Ústí nad Labem sp. zn. L 5819, Nezávislá odborová organizace Lesní závod Židlochovice (spolek), vedená u Krajského soudu v Brně sp. zn. L 19965. Jako odborová organizace je zapsán též Spolek hornických důchodců dolu J. Fučík, závodu 4 a 9 u Krajského soudu v Ostravě pod sp. zn. L 4759 a Spolek fanoušků Krotitelů duchů v likvidaci u Městského soudu v Praze, sp. zn. L 69440.

36 Odborová organizace je vedena u Krajského soudu v Ústí nad Labem pod sp. zn. L 9266.

37 Odborový svaz je veden u Městského soudu v Praze pod sp. zn. L 65359.

38 Odborová organizace je vedena u Krajského soudu v Hradci Králové pod sp. zn. L 8297. 
dějovicích však nebyl důsledný a odborové organizace označující se jako spolek zapisuje. Snaží se však zjednat nápravu následně a ukládá odborovým organizacím bliže nespecifikovanou výzvou, aby se podřídily občanskému zákoníku (sic!) a samy podaly návrh na změnu svého názvu, kde již nebude uvedeno, že se jedná o spolek či zapsaný spolek.

Se svým názorem nicméně zatím zůstává Krajský soud v Českých Budějovicích osamocen, nebot' ostatní rejstř́ḱkové soudy, a to konkrétně Městský soud v Praze a Krajské soudy v Hradci Králové, Ostravě a Ústí nad Labem nepovažují za klamavý název odborové organizace obsahující současně identifikaci, že se jedná o odborovou organizaci a spolek. $Z$ výkladové praxe vrchních soudů lze zmínit jedno usnesení, kde rovněž Vrchní soud v Olomouci považuje odborovou organizaci za spolek. ${ }^{39}$ Rozhodovací praxe Vrchního soudu je patrná z př́padu odborové organizace, kde byl její zápis odmítnut a teprve na zásah Vrchního soud v Praze došlo k jejímu zápisu. ${ }^{40}$

Přinejmenším z procesního hlediska lze předpokládat, že názor Krajského soudu v Českých Budějovicích zůstane spíše osamocen. Jak totiž judikoval Nejvyšší soud ČR, odborové organizace mají skutečně výjimečné postavení i z hlediska rejstř́kového řízení. Nejvyšší soud ve svých rozhodnutích projevil dostatečnou míru pochopení mezinárodních závazků České republiky a jistě si byl dobře vědom závěru č. 272 Digest, dle něhož překážky vzniku odborových organizací nesmí být takové povahy, která by se vyrovnala jejich zákazu. Dle závěru č. 275 a 276 Digest lze i v př́padě odborových organizací upravit formality, předepsané pro jejich vznik, nesmí však narušovat svobodu vzniku odborových organizací. Dle závěru č. 294 Digest by registrační ř́zení odborových organizací mělo být pouhou formalitou. A především dle závěru č. 302 Digest Výbor pro svobodu sdružování Správní rady Mezinárodní organizace práce věnuje pozornost tomu, zda v národní úpravě jsou dostatečně vyjasněny podmínky pro registraci odborových organizací.

Naprosto ve shodě se zmíněnými závěry a relevantní obavou z aplikačních problémů u nové právní úpravy Nejvyšší soud konstatoval: „Zápis odborové organizace do spolkového rejstřiku provede rejstřikový soud do 5 pracovnich dnů na základě oznámení o jejím založení, aniž by byl (mohl být) podán návrh na zápis do spolkového rejstř̌ku nebo by ve věci zápisu odborové organizace do spolkového rejstř́ku proběhlo (mohlo proběhnout) řizení podle Části třetí zákona č. 304/2013 Sb., o veřejných rejstř́cích fyzických a právnických osob (srov. § 121 odst. 2 a 3 zákona č. 304/2013 Sb., o veřejných rejstřícich fyzických a právnických osob).“41 Dle citovaného názoru se v případě zápisu odborové organizace tedy žádné řízení neprovádí. Pokud rejstř́ikový soud odborovou organizaci zapíše ve smyslu ust. § 121 odst. 1 ve spojení s ust. § 26 odst. 1 písm. a) zákona č. 304/2013 Sb., v platném znění, pak při současném stavu občanského soudního řádu lze najít stěží adekvátní názor, kterým by u již zapsané odborové organizace rejstř́kový soud mohl prosadit jeho změnu.

39 Usnesení Vrchního soudu v Olomouci ze dne 2. 8. 2016, sp. zn. 8 Cmo 232/2016.

40 Jmenovitě se jedná o ANO PRAZE, odbory pro hájení zaměstnanců Pražské služby, a.s., zapsaný spolek.

41 Usnesení Nejvyššího soudu ze dne 24. listopadu 2016, sp. zn. 21 Cdo 1917/2016. Srov. též usnesení Nejvyššího soudu ze dne 24. listopadu 2016, sp. zn. 21 Cdo 3520/2016 a Stanovisko občanskoprávního a obchodního kolegia Nejvyššího soudu ze dne 23. 4. 2014 k výkladu zastoupení účastníka občanského soudního ř́zení odborovou organizací. 
Pokud by rejstř́kový soud přesto v procesních předpisech našel adekvátní cestu, pak je nutno upozornit na existenci Úmluvy MOP č. 11 o svobodě sdružování v zemědělství, Úmluvy č. 87 a především čl. 27 odst. 2 Listiny základních práv a svobod. Posledně zmíněné ustanovení stanoví dva základní principy relevantní pro zkoumanou situaci. Zaprvé odborové organizace vznikají nezávisle na státu, tj. České republice. Zadruhé je nepřípustné, a to též pro rejstř́kové soudy, aby zvýhodňovaly některé odborové organizace v podniku nebo v odvětví. Jestliže tedy většina rejstř́kových soudů nepovažuje za klamavý název odborové organizace, který kromě slov odborová organizace obsahuje též slovo spolek, pak nemůže legitimně jeden z těchto soudů znevýhodnit odborové organizace, které žádají o zápis $\mathrm{v}$ jeho působnosti a klást na ně těžší požadavky než ostatní rejstř́kové soudy.

\section{ZÁVĚR}

Zákonné uchopení vzniku a právního jednání odborové organizace je vždy velmi citlivou politickou záležitostí, a to zejména z hlediska mezinárodních závazků České republiky. Jak totalitní, tak demokratické Československo v minulosti raději podvakrát ustoupilo (nejprve zákonem č. 74/1973 Sb., posléze zákonem č. 300/1990 Sb.), než aby čelilo námitkám ohledně porušování mezinárodních závazků souvisejících s koaliční svobodou. Odhlédneme-li od politických dobových reálií, pak jsou obě změny př́iznačné pro současnou situaci. $V$ prvém případě byl opuštěn formální (ROH bylo již dávno integrováno do státního organismu) povolovací režim i úprava fungování dobrovolných organizací, v druhém případě byla urychleně přijata specifická volnější úprava odborových organizací, ač obecný režim podle úmyslu zákonodárce čistě povolovací povahu mít neměl. Pro nedostatek dobových materiálů nevíme, zda raději zákonodárce novelizoval zákon o sdružování občanů dříve, než začal formálně platit též pro odborové organizace, spíše z obav před aplikační praxí či z mezinárodních sankčních mechanismů.

Stejně tak lze i v posuzovaném případě uzavř́ít, že Krajský soud v Českých Budějovicích nejspíše ustoupí praxi jiných rejstř́kových soudů a nebude masově nutit nové odborové organizace, aby se za spolek nepovažovaly. I nadále tak bude především na odborové organizaci, aby si rozhodla, zda její název by měl současně obsahovat v názvu slovo „spolek“, slova „zapsaný spolek“ či zkratku z. s. Takový postup sice není ideální, je však souladný jak s Listinou základních práv a svobod, tak s mezinárodními závazky České republiky. Kromě právní úpravy tomu nasvědčují citovaná rozhodnutí Nejvyššího soudu ČR i rozhodovací praxe obou vrchních soudů, jež dostatečně berou na zřetel smysl odborových organizací, způsob jejich vzniku i zákaz znevýhodňovat některé odborové organizace.

doc. JUDr. Martin Štefko, Ph.D.

Právnická fakulta Univerzity Karlovy

stefkom@prf.cuni.cz 



\title{
VÝPOVĚĎ PRO NADBYTEČNOST A KRITÉRIA VÝBĚRU: KOMPARATIVNÍ SROVNÁNÍ
}

\author{
JAKUB TOMŠEJ*
}

\begin{abstract}
Redundancy dismissal and selection criteria: comparative analysis
The article compares the Czech and the British legal regulation with regards to the question, whether an employer, when dismissing an employee due to redundancy, has an obligation to define and disclose criteria, based on which an employee was selected out of a pool of employees performing the same type of work.
\end{abstract}

Keywords: termination of employment; redundancy; selection criteria

Klíčová slova: skončení pracovního poměru; nadbytečnost; kritéria výběru

DOI: $10.14712 / 23366478.2019 .12$

\section{ÚVODEM}

Jedním z hlavních projevů ochranné funkce pracovního práva je, že zaměstnavatel může jednostranně vypovědět pracovní poměr jen z důvodů stanovených v zákoníku práce. Důvody, pro které tak může učinit, se v čase téměř nemění a odráží historickou zkušenost $\mathrm{s}$ tím, $\mathrm{v}$ jakých prípadech po zaměstnavateli nelze rozumně požadovat, aby zaměstnance dále zaměstnával.

Realita života je vždy pestřejší než litera zákona a nastávají tak i situace, kdy se zaměstnavatelé chtějí rozloučit se zaměstnanci z jiných než zákonem zmiňovaných důvodů. Zpravidla jde o situace, kdy je zaměstnavatel se zaměstnancem nespokojen, avšak není naplněna skutková podstata žádného výpovědního důvodu nebo hrozí, že by se v prípadě soudního sporu zaměstnavateli nepodařilo unést důkazní břemeno ohledně jejího naplnění. Důvody nespokojenosti zaměstnavatele mohou být $v$ jednotlivých případech i diskriminační nebo jinak zavrženíhodné.

$\mathrm{V}$ podobných př́ipadech zaměstnavatelé zpravidla hledají, jaký jiný výpovědní důvod by mohli použít, nebo alespoň jakým jiným výpovědním důvodem by mohli zaměstnanci hrozit a tím ho přmimět k sjednání dohody o rozvázání pracovního poměru za

\footnotetext{
* Autor je odborným asistentem na katedře pracovního práva a práva sociálního zabezpečení Právnické fakulty Univerzity Karlovy.
} 
pro ně výhodných podmínek. Asi nejjednodušší variantou je v takovém případě výpovědní důvod podle $\S 52$ písm. c) zákoníku práce, tedy nadbytečnost zaměstnance. $\mathrm{Na}$ rozdíl od ostatních důvodů pro ni totiž nemusí být splněna žádná zvláštní podmínka na straně zaměstnance ani tento důvod na straně zaměstnavatele nevyžaduje žádné výrazné změny (nadbytečnost sice musí vyplývat $\mathrm{z}$ organizační změny, ta však může spočívat právě jen ve zrušení pozice zaměstnance, který u zaměstnavatele již není vítán).

Výpovědní důvod související s nadbytečností zaměstnance je zcela legitimní a v praxi nenahraditelná věc a účelem tohoto článku není tvrdit opak. Domnívám se však, že u daného výpovědního důvodu je nutné vnímat i jeho „negativní potenciál“" související právě s možným zneužitím. Vykonává-li danou práci pro zaměstnavatele jen jediný zaměstnanec, lze tohoto negativního potenciálu využít jen do té míry, do jaké míry se zaměstnavatel bez dané práce (alespoň dočasně) obejde. Ztrátě pracovní pozice, kterou zaměstnavatel fakticky nechce zrušit, se praxe někdy snaží předejít tak, že zaměstnavatel rozhodne o zrušení pracovní pozice zaměstnance a následně vytvoří pozici velmi podobnou; podobné př́ípady nicméně často neobstojí v soudním přezkumu. ${ }^{2}$

O poznání jednodušší bývá situace zaměstnavatele tam, kde totožnou práci vykonává více zaměstnanců. $V$ takovém př́padě totiž zpravidla půjde snáze rozdělit práci zaměstnance, jehož pozice byla zrušena, mezi ostatní zaměstnance, a mnohem lépe se „ztrati““ i situace, kdy je např́klad uměle vytvořena jedna pracovní pozice jen proto, aby druhá pozice mohla být o několik měsíců později zrušena s poukazem na vzestup a pokles množství pracovních úkoli̊; judikatura $\mathrm{v}$ takových prípadech obvykle akceptuje právo zaměstnavatele změnit rozhodnutí, které se ukázalo jako nesprávné nebo neúčinné, jsou-li k tomu dány provozní důvody. ${ }^{3}$

V tomto krátkém článku bych rád pojednal o tom, jakým způsobem právo reguluje proces, $v$ němž zaměstnavatel vybírá, koho ze zaměstnanců pracujících na stejné pozici se propuštění pro nadbytečnost dotkne. Vzhledem $\mathrm{k}$ tomu, že české právo tuto oblast př́liš neřeší, pojednám pro srovnání s úpravou Velké Británie, a na závěr bych se rád zamyslel nad tím, do jaké míry by bylo vhodné se touto úpravou inspirovat.

\section{1. ČESKÁ PRÁVNÍ ÚPRAVA}

Z ustanovení § 52 písm. c) zákoníku práce vyplývá, že zaměstnavatel může dát zaměstnanci výpověd', stane-li se zaměstnanec nadbytečným vzhledem k rozhodnutí zaměstnavatele nebo př́slušného orgánu o změně jeho úkolů, technického vybavení, o snížení stavu zaměstnanců za účelem zvýšení efektivnosti práce nebo o jiných organizačních změnách. Právní teorie dovodila, že platná výpověd’ musí splňovat tři předpoklady: musí existovat rozhodnutí o organizační změně, zaměstnanec se musí stát

2 Zajímavým př́kladem z poslední doby, jak soudy $\mathrm{k}$ podobným případům přistupují, je např. rozsudek Nejvyššího soudu ČR ze dne 19. 12. 2017, sp. zn. 21 Cdo 4568/2017.

3 Srov. např. rozhodnutí Nejvyššího soudu ČR ze dne 4. 4. 2012, sp. zn. 21 Cdo 1001/2011. 
nadbytečným a mezi rozhodnutím a nadbytečností zaměstnanci musí být dána příčinná souvislost. ${ }^{4}$

Bližší postup zaměstnavatele v souvislosti s rozhodnutím o organizační změně zákon neupravuje. Ze zákona ani z judikatury nevyplývá, $v$ jaké fázi se zaměstnavatel rozhodne o tom, kterého konkrétního zaměstnance se změna dotkne, tj. zda by zaměstnavatel měl v rozhodnutí již uvést jednotlivé zaměstnance, jež budou změnou dotčeni, nebo zda má zaměstnavatel nejdřive rozhodnout o organizační změně a až následně vybrat její „oběti“. S ohledem na to, že zákon v tomto směru žádné povinnosti neukládá, i na povahu rozhodnutí, které se považuje za faktické, a nikoli právní jednání, je zřejmé, že výběr postupu je na zaměstnavateli a uvedení konkrétního jména zaměstnance v rozhodnutí nutné není. Obdobně zákon nereguluje ani proces výběru nebo jiné povinnosti, které by zaměstnavatel $\mathrm{v}$ tomto ohledu měl.

Pouze v př́padě hromadného propouštění § 62 odst. 2 a 3 zákoníku práce stanoví, že před dáním výpovědí je zaměstnavatel povinen zástupce zaměstnanců a místně př́slušnou krajskou pobočku úřadu práce informovat (kromě jiného) o hlediscích navržených pro výběr zaměstnanců, kteří mají být propuštěni, a to nejpozději 30 dnů předtím, než započne doručování výpovědí. Ve druhé zprávě Úřadu práce, kde zaměstnavatel dle $\S 62$ odst. 5 zák. práce shrnuje výsledky jednání se zástupci zaměstnanců a sumarizuje své rozhodnutí o hromadném propouštění, se již o hlediscích nic uvádět nemusí.

Zdá se, že hlavním účelem zahrnutí daného údaje pod první informační povinnost je zájem zákonodárce na tom, aby se zástupci zaměstnanců (nebo sami dotčení zaměstnanci, pokud nejsou zastoupeni) v procesu projednání záměru hromadného propouštění mohli vyjádřit $\mathrm{i} k$ navrženým kritériím výběru a popřípadě se pokusit zmírnit nepříznivé důsledky na zaměstnance tím, že navrhnou jiná kritéria. Návrhy zástupců zaměstnanců však nejsou pro zaměstnavatele závazné. S ohledem na to, že se jedná pouze o navržená kritéria a zaměstnavatel nemá ani povinnost následně sdělit, zda tato kritéria zůstávají v platnosti, se však nezdá, že by zákon s nedodržením daných kritérií spojoval jakékoli následky.

Pokud jde o kritéria výběru, Nejvyšší soud již v devadesátých letech dospěl k závěru, že zákon zaměstnavatelům umožňuje regulovat počet zaměstnanců a že o výběru zaměstnance, který je nadbytečným, rozhoduje výlučně zaměstnavatel. ${ }^{5}$ Soudy podle Nejvyššího soudu nejsou oprávněny $\mathrm{v}$ tomto směru rozhodnutí zaměstnavatele přezkoumávat.

K problematice výběru nadbytečného zaměstnance se Nejvyšší soud následně vyjádřil ještě ve dvou rozhodnutích. V prvním př́ípadě 6 se zabýval neplatností výpovědi dané žalobkyni, která vykonávala práci jako docentka na katedře jazyků vysoké školy, její pozice však byla zrušena (a de facto nahrazena pozicí odborného asistenta s odlišnou pracovní náplní, požadavky na kvalifikaci i odměňováním). Žalobkyně mimo jiné namítla i rozpor takového jednání se zásadou zákazu diskriminace, z rozhodnutí Nejvyšší-

4 Srov. DRÁPAL, L. Komentár k § 52. In: BĚLINA, M. - DRÁPAL, L. a kol. Zákoník práce. 2. vydání. Praha: Nakladatelství C. H. Beck, 2015, s. 319.

5 Rozsudek Nejvyššího soudu ze dne 25. 8. 1998, sp. zn. 2 Cdon 1130/97.

6 Rozhodnutí Nejvyššího soudu ČR ze dne 28.02.2012, sp. zn. 21 Cdo 4574/2010. 
ho soudu však nevyplývá, že by žalobkyně tvrdila, že je u ní dán některý diskriminační důvod (např. že $\mathrm{k}$ dání výpovědi došlo $\mathrm{z}$ důvodu jejího pohlaví).

$\mathrm{V}$ druhém př́padě 7 žalobce napadl výpověd' $\mathrm{z}$ důvodu nadbytečnosti proto, že se domníval, že ve skutečnosti nebyla u zaměstnavatele realizována organizační změna, nýbrž se jednalo o akt osobní odvety zaměstnavatele (resp. jeho jednatele) z důvodu „rozdílných názorů otce žalobce na vedení a správu majetku žalované společnosti“, v čemž žalobce spatřoval „diskriminaci z důvodu rozdílného světového názoru“.

Nejvyšší soud v obou daných př́padech zopakoval názor, že je na zaměstnavateli, aby vybral, který zaměstnanec se stane nadbytečným, a v prvním př́ípadu dokonce uvedl, že „protože [...] regulovat počet zaměstnanci̊ a jejich kvalifikační složení je podstatou oprávnění zaměstnavatele upravovat a ř́dit svoji vlastní činnost, nemůže být takové rozhodnutí zaměstnavatele diskriminačním jednáním; nejde ani o jednání označené v ustanovení § 16 zák. práce, prípadě v zákoně č. 198/2009 Sb.“

Výklad výše uvedených rozhodnutí může být komplikovanější. Rovné zacházení se zaměstnanci a zákaz diskriminace platí dle $\S 1$ a odst. 1 písm. e) zák. práce za základní zásadu pracovního práva a současně i za hodnotu, která chrání veřejný pořádek. Ustanovení § 16 zák. práce pak výslovně zakazuje jakoukoli diskriminaci. Rozdílné zacházení se nepovažuje za diskriminaci výjimečně jen tam, kde z povahy pracovních činností vyplývá, že takové rozdílné zacházení je podstatným požadavkem nezbytným pro výkon práce, splňuje-li taková výjimka požadavek na oprávněný účel a přiměřený požadavek (§ 16 odst. 4 zák. práce).

V souladu s tím i Nejvyšší soud v mnoha př́padech akceptoval, že ustanovení o zákazu diskriminace (at' už vyplývají z antidiskriminačního zákona, nebo přímo ze zákoníku práce) dopadají i na právní jednání zaměstnance, jimiž se končí pracovní poměr. ${ }^{8}$ Jestliže v citovaném rozsudku uvedl, že tento zákaz dopadá i na "zjednodušený” způsob skončení pracovního poměru, jakým je zrušení ve zkušební době, pak není jediný důvod, proč by nemělo dopadnout i na výpověd' pro nadbytečnost. Výše uvedené formulaci Nejvyššího soudu (vyslovené v případu, v němž zřejmě nebyly tvrzeny rozhodné skutečnosti týkající se diskriminace) je proto možno rozumět spíše tak, že diskriminačním jednáním nemůže být rozhodnutí o organizační změně (které, jak jsme uvedli výše, není právním jednáním), nýbrž až právě výpověd’.

Navzdory výše uvedenému se tak domnívám, že $\mathrm{v}$ případě, kdy zaměstnanec prokáže, že byl pro nadbytečnost vybrán výlučně z diskriminačních důvodů, je na místě, aby výpověd' byla $\mathrm{v}$ takovém př́padě posouzena jako neplatná. Tento závěr ostatně potvrdil i Ústavní soud, když v jednom případě $\mathrm{k}$ výše uvedenému názoru Nejvyššího soudu vyslovil tuto repliku: „Provádět organizační změny je jistě přirozené a nutné, ovšem tato svoboda zaměstnavatele nutně podléhá korektivu v podobě zákazu rozlišovat osoby, jichž se změny dotknou, podle nepřijatelných kritérii zapovězených Listinou. V tomto smyslu je nutno usměrnit úvahu obecných soudü, že je věcí zaměstnavatele, které zaměstnance v prípadě organizačních změn vybere jako nadbytečné. Naopak, obzvláště ve světle stěžovatelem předložené statistiky bylo žádoucí pozorně zkoumat, zda jako

7 Rozhodnutí Nejvyššího soudu ČR ze dne 15.08.2012, sp. zn. 21 Cdo 2536/2011.

8 Rozhodnutí Nejvyššího soudu ze dne 21. 4. 2009, sp. zn. 21 Cdo 2195/2008.. 
kritérium pro výběr nadbytečných nebyl skrytě zvolen jejich věk (eventuálně snad jiný znak, který byl zákonikem práce vyloučen).“9

Pokud postup zaměstnavatele nelze označit za diskriminační, pak je zřejmé, že se v plném rozsahu uplatní výše popsaný názor Nejvyššího soudu, podle něhož je výběr zaměstnance dotčeného organizační změnou, včetně výběrových kritérií (nebo skutečnosti, že se zaměstnavatel rozhodl zcela nahodile bez výběrových kritérií) na rozhodnutí zaměstnavatele a soud jej nebude přezkoumávat.

\section{BRITSKÁ PRÁVNÍ ÚPRAVA}

Ochranná ustanovení britského pracovního práva jsou zahrnuta zejména v zákoně o právech zaměstnanců (Employment Rights Act - ERA 1996). Ten obsahuje i ustanovení o skončení pracovního poměru. Jedním z důvodů skončení pracovního poměru je i nadbytečnost zaměstnance (článek 139 ERA), která mírí na stejné případy v praxi, jako je tomu v ČR. ${ }^{10}$

Aby skončení pracovního poměru pro nadbytečnost bylo platné, musí být dle britské doktríny splněny dvě podmínky: jednak musí být záměr propuštění se zaměstnancem předem projednán a jednak musí být zvolena správná kritéria výběru. ${ }^{11}$ Kritéria výběru samozřejmě přijdou na řadu jen tehdy, kde by rozhodnutím o nadbytečnosti mohlo být dotčeno více zaměstnanců, avšak zaměstnavatel se chce rozloučit jen s některými $\mathrm{z}$ nich. K věci se váže klíčové soudní rozhodnutí ve věci Williams v Compair Maxam Limited $^{12}$ ( $\mathrm{z}$ doby ještě před přijetím zákona ERA). Z něho vyplývá, že kritéria výběru musí být zaměstnavatelem stanovena objektivně a zahrnovat hlediska jako napríklad docházka, efektivita práce, zkušenost, délka pracovního poměru, a neměla by být založena výlučně na subjektivním názoru hodnotící osoby. Výběr nadbytečného zaměstnance by pak měl proběhnout spravedlivě za zohlednění daných kritéríi.

Právo nestanoví, jaká konkrétní kritéria by měla být používána, a nechává tedy toto rozhodnutí na zaměstnavatelích. V ERA však najdeme ustanovení obsahující mnoho hledisek, k nimž zaměstnavatelé přihlížet nesmějí: kromě jiného jde o skutečnosti spojené s rodinným stavem zaměstnance, aktivitu v oblasti BOZP, podání žádosti o flexibilní pracovní dobu, důvody související s uplatňováním zákonných práv zaměstnanců, členstvím v odborové organizaci a podobně. ${ }^{13}$ Použití diskriminačního kritéria by ve všech př́padech vedlo $\mathrm{k}$ závěru o neplatnosti výpovědi (unfair dismissal). Problémová jsou i nedostatečně objektivní kritéria v zákoně výslovně neuvedená (napřs. „,oddanost““ zaměstnavateli v prŕípadu Everitt v Sealine International Limited $\left.{ }^{14}\right)$.

\footnotetext{
9 Nález Ústavního soudu ze dne 30. 4. 2009, sp. zn. II. ÚS 1609/08

${ }^{10} \mathrm{~K}$ pojmu nadbytečnosti v britském právním řádu srov. též UPEX, R. - HARDY, S. The Law of Termination of Employment. 8. vydání. Bristol: Jordan Publishing, 2012.

11 YEW, J. (ed.). Termination of Employment. Issue 61. Londýn: Bloomsbury Professional, 2018, část C1, S. 50 .

12 Williams v Compair Maxam Ltd [1982] ICR 156. Jde o rozhodnutí Pracovního odvolacího tribunálu (Employment Appeal Tribunal).

13 Srov. zejména ustanovení § 98 - 105 ERA (1996).

14 Everitt v Sealine International Limited, Employment Tribunal, 13134646/09.
} 
Doktrína ${ }^{15}$ tak uvádí, že za objektivní a přípustná kritéria je možno považovat zejména výkon, schopnosti, kvalifikaci, pracovní kázeň, dodržování pracovní doby a přesnost a podobná hlediska.

Aplikace těchto kritérií z praktického pohledu znamená, že v některých případech může dojít $\mathrm{k}$ (skutečnému či zdánlivému) souběhu dvou výpovědních důvodů. Pokud by např́klad byl zaměstnanec propouštěný pro nadbytečnost vybrán na základě toho, že měl největší problémy s dodržováním pracovní doby, mohou být ve hře dva výpovědní důvody: nadbytečnost a porušování pracovních povinností. Nepřekvapí, že britské právo v takovém př́padě za klíčový považuje důvod nadbytečnosti, a v souvislosti s možným porušováním povinností zaměstnance na výpověd' nejsou kladeny nároky, které by zaměstnavatel musel splnit, pokud by výpověd' byla dána $\mathrm{z}$ tohoto důvodu (zejména tedy není nutné, aby intenzita porušení odůvodňovala skončení pracovního poměru z důvodu porušování povinností zaměstnance). ${ }^{16}$

V př́padu Alexander v Brigden Enterprises ${ }^{17}$ Pracovní odvolací tribunál rozhodl, že povinností zaměstnavatele je seznámit zaměstnance s tím, jaká výběrová kritéria zvolil a jak byl zaměstnanec hodnocen.

V praxi je běžné, že detaily postupu upravují vnitřní předpisy zaměstnavatele. Pro názornost je možno odkázat na veřejně dostupnou ,Redundancy Policy“ Birkback University of London, ${ }^{18}$ která stanoví, že v prípadě nezaměstnanosti je povinností zaměstnavatele (v konkrétní rovině vedoucího daného oddělení po dohodě s HR) určit skupinu zaměstnanců, mezi nimiž bude proveden výběr (tzv. selection pool). Současně stanoví kritéria výběru, která budou se zaměstnanci projednána. Vnitřní předpis nestanoví závazná kritéria, uvádí však jejich demonstrativní výčet. ${ }^{19} \mathrm{Na}$ základě těchto kritérií budou zaměstnanci posouzeni; dodejme, že toto posouzení v praxi zpravidla probíhá tak, že zástupci zaměstnavatele jednotlivé zaměstnance bodují a následně se porovnává, který zaměstnanec získal nejméně bodů. ${ }^{20}$ Celý postup a jeho výsledek musí být písemně zdokumentován. Judikatura však samozřejmě respektuje právo zaměstnavatele posoudit splnění jednotlivých kritérií a tento krok je tak zpravidla soudy přezkoumáván nanejvýš jen v omezeném rozsahu. ${ }^{21}$

\section{ZÁVĚREM}

Zákonná ustanovení o skončení pracovního poměru musí rozumně vyvažovat zájem zaměstnavatele na svobodě podnikání, k němuž patř́i i (pro jednotlivé

15 Op. cit. sub. 9, s. 53.

16 Kol. autorů: Redundancy. Employment law handbook. Londýn: Thomson Reuters (Professional) UK, 2016, s. 94 .

17 Alexander and Hatherley v Bridgen Enterprises Ltd: [2006] UKEAT 0107_06_1204.

18 Srov. <http://www.bbk.ac.uk/hr/policies_services/policies_az/redundancypolicy2013>.

19 Zajímavostí je, že v tomto případě jde o vysokou školu a jēním ze zvolených kritérií je i zpětná vazba od studentu.

20 Taková praxe vyplývá z osobních zkušeností autora i mj. z rozhodnutí Watkins v Crouch t/a Temple Bird Solicitors 2011 IRLR 382, o kterém rozhodoval Pracovní odvolací tribunál.

21 Op. cit. sub 14, s. 295. 
zaměstnance mnohdy nepř́ijemná) rozhodnutí o organizačních změnách, a zájem zaměstnance na stabilitě pracovního poměru. Pokud jde o skončení pracovního poměru pro nadbytečnost, klade náš právní ŕád důraz zejména na flexibilitu na straně zaměstnavatele. Ochrana zaměstnance je pak zajištěna zejména prostřednictvím výpovědní doby a odstupného, jimiž je zaměstnanec $\mathrm{v}$ případě skončení pracovního poměru alespoň na nějakou dobu zajištěn.

Byt' možnost zneužití výpovědi pro nadbytečnost není nijak nová22 domnívám se, že české právo nedostatečně chrání zaměstnance před tímto rizikem. Závěr judikatury o tom, že výběr zaměstnance dotčeného nadbytečností je zcela na zaměstnavateli, není v kontextu naší právní úpravy překvapivý, zásadám zvláštní zákonné ochrany postavení zaměstnance a dalším zásadám pracovního práva by však dle mého názoru lépe vyhovoval jiný př́istup. Za překvapivou a složitou pak považuji situaci ve vztahu k možným diskriminačním důvodům, kde judikatura Nejvyššího soudu (byt' částečně korigovaná judikaturou soudu Ústavního) může vést adresáty práva $\mathrm{k}$ (dle mého názoru nesprávnému) závěru, že ani v tomto př́padě nejsou před výpovědí chráněni.

Britská právní úprava skončení pracovního poměru pro nadbytečnost prošla dlouhým vývojem a je velmi složitá. Pro zaměstnavatele z ní vyplývá řada povinností, z nichž ne všechny mohou být přenositelné do našeho právního řádu. Domnívám se nicméně, že tato úprava v hrubých obrysech vede $\mathrm{k}$ spravedlivějšímu nastavení pracovního trhu. Každý racionální zaměstnavatel, který provádí upř́ímně míněnou organizační změnu, totiž beztak musí projít kroky, s nimiž britská úprava pracuje: určit kritéria výběru nadbytečného zaměstnance a za pomoci těchto kritérií rozhodnout. Pokud by tedy i u nás zákon zaměstnavatelům výslovně uložil oba kroky provést, nepožadoval by po nich nic nového ani nadbytečného, a nelze předpokládat ani významné navýšení administrativní zátěže. Výslovná povinnost formulovat výběrová kritéria a řídit se jimi však zaměstnance ochrání v řadě př́padů, kdy zaměstnavatel institut výpovědi pro nadbytečnost chce zneužít nebo zvolit kritéria zavrženíhodná. Domnívám se proto, že základ britské právní úpravy (spočívající právě v povinném vymezení kritérií výběru a jejich dodržení) by mohl být vhodnou inspirací i pro českého zákonodárce.

JUDr. Jakub Tomšej, Ph.D.

Právnická fakulta Univerzity Karlovy

tomsej@prf.cuni.cz

22 Lze odkázat např̀. na práci ŠTEFKO, M. Výpověd’ pro nadbytečnost jako nástroj diskriminace z důvodu věku, Právní rozhledy, 2018, č. 15-16. 



\section{REDAKČNÍ RADA}

Předseda a šéfredaktor: prof. JUDr. Pavel Šturma, DrSc.

Tajemnice: Mgr. Naděžda Svobodová

Členové:

doc. PhDr. JUDr. Ilona Bažantová, CSc.

prof. JUDr. Stanislava Černá, CSc.

doc. JUDr. PhDr. David Elischer, Ph.D.

prof. JUDr. Marie Karfíková, CSc.

doc. JUDr. Martin Kopecký, CSc.

prof. JUDr. Jan Kysela, Ph.D., DSc.

doc. JUDr. PhDr. Pavel Maršálek, Ph.D.

prof. JUDr. Monika Pauknerová, CSc., DSc.

JUDr. Bc. Vladimír Pelc, Ph.D.

prof. JUDr. Michal Skřejpek, DrSc.

doc. JUDr. Vojtěch Stejskal, Ph.D.

prof. JUDr. PhDr. Michal Tomášek, DrSc.

Externí členové:

prof. JUDr. Michael Bogdan (University of Lund)

doc. JUDr. František Cvrček, CSc. (ÚSP AV ČR, Praha)

prof. Dr.hab. Wladyslaw Czaplinski (Institut Nauk prawnych Warszawa)

prof. JUDr. Jaroslav Fenyk, Ph.D., DSc. (Ústavní soud Brno)

prof. JUDr. Jan Filip, CSc. (Ústavní soud Brno)

prof. Dr. Michael Geistlinger (Universität Salzburg)

prof. JUDr. Pavel Holländer, DrSc. (PF UPJŠ Košice)

Dr. Kaspar Krolop (Humboldt Universität Berlin)

prof. JUDr. Jan Musil, CSc. (Ústavní soud Brno)

prof. JUDr. Václav Pavlíček, CSc., dr.h.c. (Západočeská univerzita, Plzeň)

prof. JUDr. Jiří Přibáň, DrSc. (Cardiff University)

prof. JUDr. Ján Svák, DrSc. (Ministerstvo spravodlivosti SR, Bratislava)

JUDr. Milada Tomková (Ústavní soud Brno)

prof. Dr. Miroslav Vitéz (Ekonomiski fakultet u Subotici)

prof. JUDr. Ladislav Vojáček, CSc. (Masarykova univerzita Brno)

prof. JUDr. Petr Tröster, CSc. (Praha)

prof. JUDr. Alena Winterová, CSc. (Praha) 
ACTA

UNIVERSITATIS

CAROLINAE

IURIDICA 1/2019

Časopis Acta Universitatis Carolinae - Iuridica je evidován v České národní bibliografii (vedena Národní knihovnou ČR), na seznamu recenzovaných vědeckých časopisů RVVI, v Index to Foreign Legal Periodicals (veden American Association of Law Libraries) a je rovněž indexován Central and Eastern European Online Library (www.ceeol.com).

Vědecký redaktor: JUDr. Jakub Tomšej, Ph.D.

Vydala Univerzita Karlova

Nakladatelství Karolinum, Ovocný trh 560/5, 11636 Praha 1

Praha 2019

www.karolinum.cz

Sazba DTP Nakladatelství Karolinum

Vytiskla tiskárna Nakladatelství Karolinum

Periodicita: $4 \times /$ rok

ISSN 0323-0619 (Print)

ISSN 2336-6478 (Online)

MK ČR E 18585 